\title{
Thiophene-fused ח-Systems from Diarylacetylenes and Elemental Sulfur
}

\author{
Lingkui Meng, ${ }^{a, b}$ Takao Fujikawa, ${ }^{b}$ Motonobu Kuwayama, ${ }^{b, c}$ Yasutomo Segawa, ${ }^{b, c, \star}$ \\ and Kenichiro Itami ${ }^{a, b, c, d, *}$ \\ ${ }^{a}$ Integrated Research Consortium on Chemical Sciences, Nagoya University, Chikusa, Nagoya 464-8602, \\ Japan. \\ ${ }^{b}$ Graduate School of Science, Nagoya University, Japan. \\ 'JST, ERATO, Itami Molecular Nanocarbon Project, Nagoya University, Japan. \\ ${ }^{d}$ Institute of Transformative Bio-Molecules (WPI-ITbM), Nagoya University, Japan. \\ E-mail: ysegawa@nagoya-u.jp (YS),itami@chem.nagoya-u.ac.jp (KI)
}

\section{Table of Contents}

1. Experimental Section

2. X-ray Crystallography

3. Photophysical Properties

S33-40

4. Kinetic Study

5. Theoretical Study

6. References

7. ${ }^{1} \mathrm{H}$ NMR and ${ }^{13} \mathrm{C}$ NMR Spectra

S50-90 


\section{Experimental Section}

\section{1-1. General Procedure}

Unless otherwise noted, all materials were obtained from commercial suppliers and used without further purification. Unless otherwise noted, sulfur crystal 99.999\% (Nakarai, Cat. No. 32514-32) and $N, N$-dimethylformamide super dehydrated (Wako, Cat. No. 045-32365) were used for thienannulation. 9-Phenanthryl trifluoromethanesulfonate, ${ }^{1}$ naphthalene-1,3-diyl bis(trifluoromethanesulfonate), ${ }^{2}$ bromocorannulene ${ }^{3 \mathrm{a}} \quad$ 9-ethynylphenanthrene, ${ }^{4} \quad$ 6,12,18-tribromobenzo[c]naphtho[2,1- $\left.p\right]$ chrysene, ${ }^{3 \mathrm{~b}}$ 1,3-di-tert-butyl-5-ethynylbenzene, ${ }^{5}$ 1,3,5,7,9-pentachlorocoranulene, ${ }^{3 a} 9$-(bromoethynyl)phenanthrene, ${ }^{6}$ and 1-ethynyl-4- $n$-octylbenzene ${ }^{7}$ were prepared according to the procedures reported in the literatures. All reactions were performed using standard vacuum-line and Schlenk techniques. Work-up and purification procedures were carried out with reagent-grade solvents under air. Analytical thin-layer chromatography (TLC) was performed using E. Merck silica gel $60 \mathrm{~F} 254$ precoated plates $(0.25 \mathrm{~mm})$. The developed chromatograms were analyzed by UV lamp $(254 \mathrm{~nm})$. Flash column chromatography was performed with E. Merck silica gel 60 (230-400 mesh). Preparative thin-layer chromatography (PTLC) was performed using Wako-gel ${ }^{\circledR}$ B5-F silica coated plates $(0.75 \mathrm{~mm})$ prepared in our laboratory. Preparative recycling gel permeation chromatography (GPC) was performed with a JAI LC-9260 II NEXT instrument equipped with JAIGEL-1H/JAIGEL-2H columns using chloroform as an eluent. The high-resolution mass spectra (HRMS) were conducted on Bruker Daltonics Ultraflex III TOF/TOF (MALDI-TOF-MS) and Thermo Fisher Scientific Exactive (ESI). Melting points were measured on a MPA100 Optimelt automated melting point system. ICP-MS was performed with Shimadzu ICPM-8500. Nuclear magnetic resonance (NMR) spectra were recorded on a JEOL ECA $500 \mathrm{II}$ spectrometer $\left({ }^{1} \mathrm{H} 500 \mathrm{MHz},{ }^{13} \mathrm{C} 125 \mathrm{MHz}\right)$. Chemical shifts for ${ }^{1} \mathrm{H}$ $\mathrm{NMR}$ are expressed in parts per million (ppm) relative to $\mathrm{CHCl}_{3}(\delta 7.26 \mathrm{ppm})$. Chemical shifts for ${ }^{13} \mathrm{C}$ NMR are expressed in ppm relative to $\mathrm{CDCl}_{3}(\delta 77.0 \mathrm{ppm})$, or $\mathrm{C}_{2} \mathrm{D}_{2} \mathrm{Cl}_{4}(\delta 73.7 \mathrm{ppm})$. Data are reported as follows: chemical shift, multiplicity $(\mathrm{s}=$ singlet, $\mathrm{d}=$ doublet, $\mathrm{t}=$ triplet, quint $=$ quintet, sext $=$ sextet, $\mathrm{m}=$ multiplet $)$, coupling constant $(\mathrm{Hz})$, and integration. 


\section{1-2. Thienannulation Reactions}

Synthesis of $2 a$

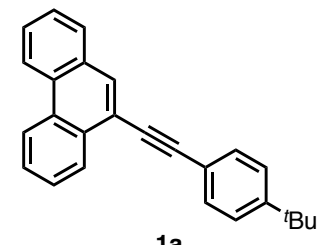

$1 \mathrm{a}$

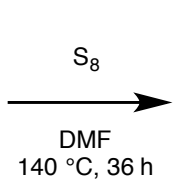

$140{ }^{\circ} \mathrm{C}, 36 \mathrm{~h}$

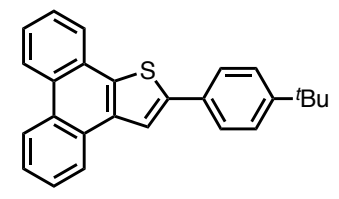

2a

To a 10-mL Schlenk tube containing a magnetic stirring bar were added $1 \mathbf{a}$ (33.4 mg, $100 \mu$ mol, produced by Method A; see Section 1-3) and $\mathrm{S}_{8}(25.6 \mathrm{mg}, 100 \mu \mathrm{mol})$. The flask was filled with argon, then DMF (1.0 mL) was added to the tube and the mixture was heated at $140{ }^{\circ} \mathrm{C}$ for $36 \mathrm{~h}$. The mixture was then cooled to room temperature. The crude solution was concentrated in vacuo. The residue was subjected to PTLC $\left(\mathrm{CHCl}_{3} /\right.$ hexane $\left.=1: 10\right)$ to afford $\mathbf{2 a}(33.7 \mathrm{mg}, 92 \%$ yield $)$ as white solid.

${ }^{1} \mathrm{H}$ NMR $\left(500 \mathrm{MHz}, \mathrm{CDCl}_{3}\right) \delta 8.72-8.68(\mathrm{~m}, 2 \mathrm{H}), 8.36(\mathrm{dd}, J=7,2 \mathrm{~Hz}, 1 \mathrm{H}), 8.15-8.13(\mathrm{~m}, 2 \mathrm{H}), 7.77(\mathrm{~d}, J=$ $9 \mathrm{~Hz}, 2 \mathrm{H}), 7.68-7.61(\mathrm{~m}, 4 \mathrm{H}) 7.50(\mathrm{~d}, J=9 \mathrm{~Hz}, 2 \mathrm{H}), 1.39(\mathrm{~s}, 9 \mathrm{H}) ;{ }^{13} \mathrm{C}$ NMR $\left(125 \mathrm{MHz}, \mathrm{CDCl}_{3}\right) \delta 151.3$, 143.4, 135.9, 135.8, 131.5, 129.1, 128.7, 128.5, 128.2, 127.2 , 127.0, 126.1 , 126.0, 124.2 , 124.1, 123.6, 123.5, 118.3, 34.7, 31.3; HRMS (ESI-MS) $\mathrm{m} / z$ calcd for $\mathrm{C}_{26} \mathrm{H}_{22} \mathrm{~S}[\mathrm{M}+\mathrm{H}]^{+}: 367.1515$, found: 367.1507 ; mp: 149$151^{\circ} \mathrm{C}$.

\section{Decagram-scale synthesis of $\mathbf{2 a}$}

To a 500-mL Schlenk flask containing a magnetic stirring bar were added 1a (17.8 g, 53.2 mmol, produced by Method A; see Section 1-3) and $\mathrm{S}_{8}(13.6 \mathrm{~g}, 53.2 \mathrm{mmol})$. The flask was filled with argon, then DMF (200 $\mathrm{mL}$ ) was added to the flask and the mixture was heated at $140{ }^{\circ} \mathrm{C}$ for $36 \mathrm{~h}$. The mixture was then cooled to room temperature. The crude solution was concentrated in vacuo. The compound 2a was purified by recrystallization from $\mathrm{CH}_{2} \mathrm{Cl}_{2} / \mathrm{MeOH}$ solution (18.0 g, 93\% yield).

\section{Synthesis of $\mathbf{2 a}$ via one-pot Sonogashira coupling-thinannulation}
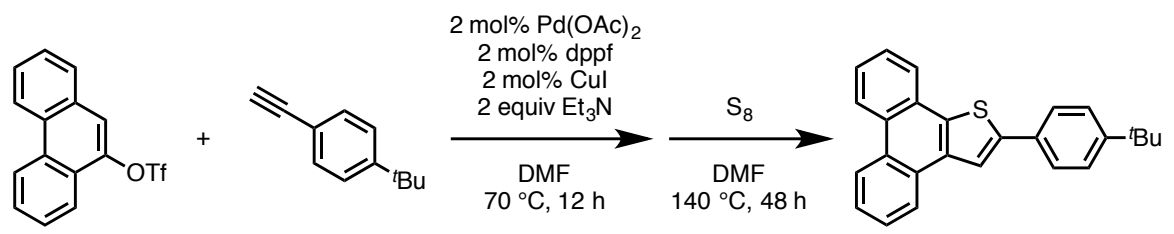

2a

To a 10-mL Schlenk tube containing a magnetic stirring bar were added phenanthren-9-yl trifluoromethanesulfonate $\quad(163 \mathrm{mg}, \quad 500 \mu \mathrm{mol}), \quad \mathrm{Pd}(\mathrm{OAc})_{2} \quad\left(\begin{array}{lllll}2.2 & \mathrm{mg}, & 10.0 & \mu \mathrm{mol}\end{array}\right), \quad \mathrm{dppf}$ (1,1'-bis(diphenylphosphino)ferrocene, $5.5 \mathrm{mg}, 10.0 \mu \mathrm{mol})$, and CuI $(1.9 \mathrm{mg}, 10.0 \mu \mathrm{mol})$. The tube was filled with argon, then DMF (5.0 mL), $\mathrm{Et}_{3} \mathrm{~N}(101 \mathrm{mg}, 1.00 \mathrm{mmol})$ and 1-(tert-butyl)-4-ethynylbenzene (79.0 $\mathrm{mg}, 500 \mu \mathrm{mol})$ were added and the mixture was heated at $70{ }^{\circ} \mathrm{C}$ for $12 \mathrm{~h}$. Then $\mathrm{S}_{8}(385 \mathrm{mg}, 1.50 \mathrm{mmol})$ was added to the reaction mixture under argon atmosphere and heated at $140{ }^{\circ} \mathrm{C}$ for $48 \mathrm{~h}$. The mixture was then cooled to room temperature. The crude solution was concentrated in vacuo. The residue was subjected to PTLC $\left(\mathrm{CHCl}_{3} /\right.$ hexane $\left.=1: 10\right)$ to afford $\mathbf{2 a}(128 \mathrm{mg}, 70 \%$ yield $)$ as white solid. 
Synthesis of 2 a with TEMPO as a radical scavenger
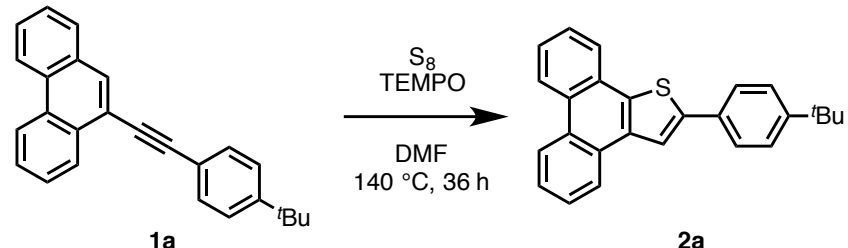

$2 a$

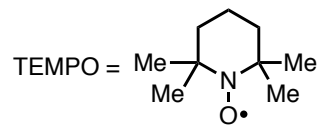

To a $10-\mathrm{mL}$ Schlenk tube containing a magnetic stirring bar were added 1a $(34.2 \mathrm{mg}, 102 \mu \mathrm{mol}$, produced by Method A; see Section 1-3), $\mathrm{S}_{8}(25.6 \mathrm{mg}, 100 \mu \mathrm{mol})$, and TEMPO (15.6 mg, $\left.100 \mu \mathrm{mol}\right)$. The flask was filled with argon, then DMF $(1.0 \mathrm{~mL})$ was added to the tube and the mixture was heated at $140{ }^{\circ} \mathrm{C}$ for $36 \mathrm{~h}$. The mixture was then cooled to room temperature. The crude solution was concentrated in vacuo. The residue was subjected to PTLC $\left(\mathrm{CHCl}_{3} /\right.$ hexane $\left.=1: 10\right)$ to afford $\mathbf{2 a}(32.1 \mathrm{mg}, 86 \%$ yield $)$ as white solid.

Synthesis of 2 a with galvinoxyl as a radical scavenger<smiles>Brc1ccc(C#Cc2cc3ccccc3c3ccccc23)cc1</smiles>

$1 \mathrm{a}$

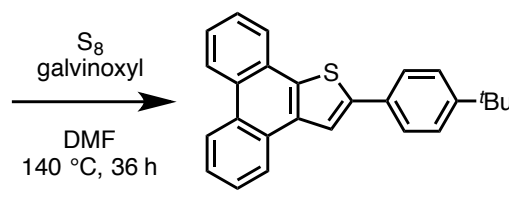

$2 a$

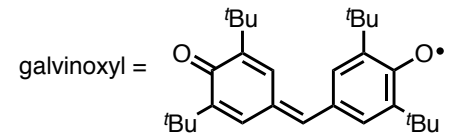

To a $10-\mathrm{mL}$ Schlenk tube containing a magnetic stirring bar were added $1 \mathrm{a}$ (33.9 $\mathrm{mg}, 101 \mu \mathrm{mol}$, produced by Method A; see Section 1-3), $\mathrm{S}_{8}(25.6 \mathrm{mg}, 100 \mu \mathrm{mol})$, and galvinoxyl $(42.1 \mathrm{mg}, 100 \mu \mathrm{mol})$. The flask was filled with argon, then DMF (1.0 mL) was added to the tube and the mixture was heated at $140{ }^{\circ} \mathrm{C}$ for $36 \mathrm{~h}$. The mixture was then cooled to room temperature. The crude solution was concentrated in vacuo. The residue was subjected to PTLC $\left(\mathrm{CHCl}_{3} /\right.$ hexane $\left.=1: 10\right)$ to afford $\mathbf{2 a}(31.1 \mathrm{mg}, 84 \%$ yield $)$ as white solid.

\section{Synthesis of $\mathbf{2 a - D}$}

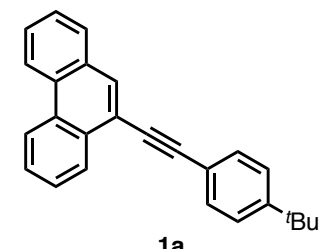

1a

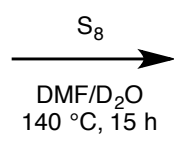
$140{ }^{\circ} \mathrm{C}, 15 \mathrm{~h}$

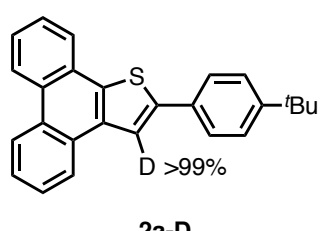

2a-D

To a $10-\mathrm{mL}$ Schlenk tube containing a magnetic stirring bar were added $\mathbf{1 a}(66.8 \mathrm{mg}, 200 \mu \mathrm{mol}$, produced by Method A; see Section 1-3) and $\mathrm{S}_{8}(51.2 \mathrm{mg}, 100 \mu \mathrm{mol})$. The flask was filled with argon, then DMF (1.0 mL) and $\mathrm{D}_{2} \mathrm{O}(0.1 \mathrm{~mL})$ were added to the tube and the mixture was heated at $140{ }^{\circ} \mathrm{C}$ for $15 \mathrm{~h}$. The mixture was then cooled to room temperature. The crude solution was concentrated in vacuo. The residue was subjected to PTLC $\left(\mathrm{CHCl}_{3} /\right.$ hexane $\left.=1: 10\right)$ and GPC to afford 2a-D $(65.4 \mathrm{mg}, 89 \%$ yield, $>99 \%$ deuterated $)$ as white solid.

${ }^{1} \mathrm{H}$ NMR $\left(500 \mathrm{MHz}, \mathrm{CDCl}_{3}\right) \delta 8.72-8.68(\mathrm{~m}, 2 \mathrm{H}), 8.36(\mathrm{dd}, J=7,2 \mathrm{~Hz}, 1 \mathrm{H}), 8.15-8.13(\mathrm{~m}, 1 \mathrm{H}), 7.77(\mathrm{~d}, J=$ $9 \mathrm{~Hz}, 2 \mathrm{H}), 7.68-7.61(\mathrm{~m}, 4 \mathrm{H}) 7.50(\mathrm{~d}, \mathrm{~J}=9 \mathrm{~Hz}, 2 \mathrm{H}), 1.39(\mathrm{~s}, 9 \mathrm{H})$; HRMS (MALDI-TOF-MS) $\mathrm{m} / \mathrm{z}$ calcd for $\mathrm{C}_{26} \mathrm{H}_{21} \mathrm{DS}[\mathrm{M}]^{+}: 367.1515$, found: 367.1502 . 
Table S1. Effect of the source of $\mathrm{S}_{8}$ and DMF to the synthesis of $\mathbf{2 a} .^{\mathrm{a}}$

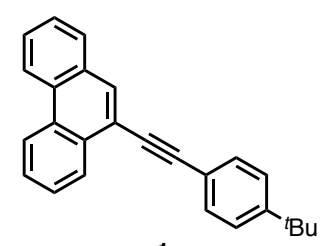

$1 \mathrm{a}$

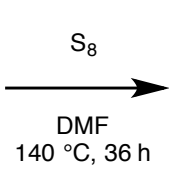

$140^{\circ} \mathrm{C}, 36 \mathrm{~h}$

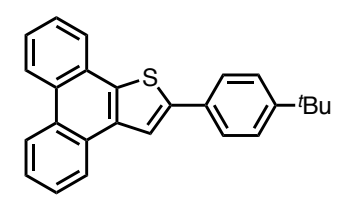

$2 \mathbf{a}$

\begin{tabular}{lll}
\hline $\mathrm{S}_{8}$ source & DMF source & yield $^{\mathrm{b}}$ \\
\hline Nakarai, 99.999\% (Cat. No. 32514-32) & Wako, super dehydrated, $\geq 99.5 \%$ (Cat. No. 045-32365) & $85 \%$ \\
Aldrich, 99.998\% (Cat. No. 213292) & Wako, super dehydrated, $\geq 99.5 \%$ (Cat. No. 045-32365) & $84 \%$ \\
Wako, 99.999\% (Cat. No. 199-17891) & Wako, super dehydrated, $\geq 99.5 \%$ (Cat. No. 045-32365) & $87 \%$ \\
Kanto, $\geq 99.5 \%$ (Cat. No. 37385-30) & Wako, super dehydrated, $\geq 99.5 \%$ (Cat. No. 045-32365) & $85 \%$ \\
Nakarai, 99.999\% (Cat. No. 32514-32) & Aldrich, for HPLC, $\geq 99.9 \%$ (Cat. No. 270547) & $86 \%$ \\
Kanto, $\geq 99.5 \%$ (Cat. No. 37385-30) & Kanto, reagent grade, $\geq 99.0 \%$ (Cat. No. 11339-05) & $77 \%$ \\
\hline
\end{tabular}

(a) Starting material 1a produced by Method B ( $\mathrm{Pd}<1 \mathrm{ppm}$ measured by ICP-MS) was used for all reactions.

(b) ${ }^{1} \mathrm{H}$ NMR yield with 1,3,5-trimethoxybenzene as an internal standard. (c) $\mathrm{Pd}<1 \mathrm{ppm}$ measured by ICP-MS. (d) Pd < 1 ppm measured by ICP-MS. (e) Reaction was conducted under air. 
Synthesis of $\mathbf{2 b}$

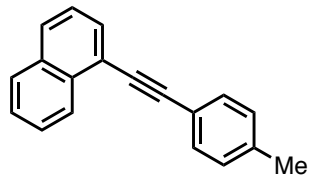

$1 b$

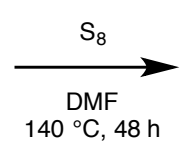

$140{ }^{\circ} \mathrm{C}, 48 \mathrm{~h}$

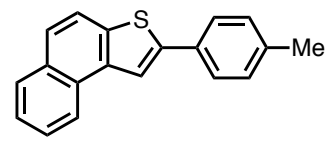

$2 b$

To a $10-\mathrm{mL}$ Schlenk tube containing a magnetic stirring bar were added $\mathbf{1 b}(122 \mathrm{mg}, 500 \mu \mathrm{mol})$ and $\mathrm{S}_{8}(128$ $\mathrm{mg}, 500 \mu \mathrm{mol})$. The tube was filled with argon, then DMF $(1.5 \mathrm{~mL})$ was added to the tube and the mixture was heated at $140{ }^{\circ} \mathrm{C}$ for $48 \mathrm{~h}$. The mixture was then cooled to room temperature. The crude solution was concentrated in vacuo. The residue was subjected to PTLC $\left(\mathrm{CHCl}_{3} /\right.$ hexane $\left.=1: 10\right)$ and GPC to afford $\mathbf{2 b}$ (77.0 $\mathrm{mg}, 56 \%$ yield) as white solid.

${ }^{1} \mathrm{H}$ NMR $\left(500 \mathrm{MHz}, \mathrm{CDCl}_{3}\right) \delta 8.36(\mathrm{~d}, J=9 \mathrm{~Hz}, 1 \mathrm{H}), 8.16(\mathrm{~s}, 1 \mathrm{H}), 7.94(\mathrm{~d}, J=8 \mathrm{~Hz}, 1 \mathrm{H}), 7.84(\mathrm{~d}, J=8 \mathrm{~Hz}$, 1H), 7.73-7.69 (m, 3H), $7.62(\mathrm{t}, J=8 \mathrm{~Hz}, 1 \mathrm{H}), 7.53(\mathrm{t}, J=8 \mathrm{~Hz}, 1 \mathrm{H}), 7.27(\mathrm{~d}, J=8 \mathrm{~Hz}, 2 \mathrm{H}), 2.42(\mathrm{~s}, 3 \mathrm{H})$; ${ }^{13} \mathrm{C}$ NMR $\left(125 \mathrm{MHz}, \mathrm{CDCl}_{3}\right) \delta 144.2,138.1,136.9,136.8,131.7,131.1,129.7,129.2,128.6,126.4,126.2$, 125.2, 124.8, 123.5, 120.5, 117.1, 21.2; HRMS (DART-MS) $\mathrm{m} / z$ calcd for $\mathrm{C}_{15} \mathrm{H}_{15} \mathrm{~S}[\mathrm{M}+\mathrm{H}]^{+}: 275.0889$, found: 275.0911 ; mp: $114-116^{\circ} \mathrm{C}$.

Synthesis of $2 c$
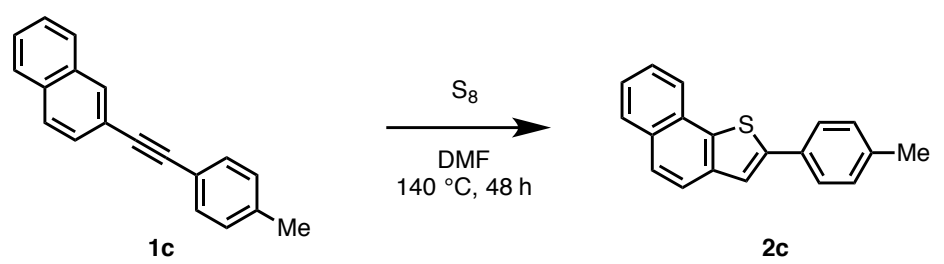

2c

To a $10-\mathrm{mL}$ Schlenk tube containing a magnetic stirring bar were added $1 \mathrm{c}(115 \mathrm{mg}, 480 \mu \mathrm{mol})$ and $\mathrm{S}_{8}(129$ $\mathrm{mg}, 500 \mu \mathrm{mmol})$. The tube was filled with argon, then DMF $(2.0 \mathrm{~mL})$ was added to the tube and the mixture was heated at $140{ }^{\circ} \mathrm{C}$ for $48 \mathrm{~h}$. The mixture was then cooled to room temperature. The crude solution was concentrated in vacuo. The residue was subjected to PTLC $\left(\mathrm{CHCl}_{3} /\right.$ hexane $\left.=1: 10\right)$ and GPC to afford 2c (65.0 mg, 50\% yield) as white solid.

${ }^{1} \mathrm{H}$ NMR $\left(500 \mathrm{MHz}, \mathrm{CDCl}_{3}\right) \delta 8.12(\mathrm{~d}, J=8 \mathrm{~Hz}, 1 \mathrm{H}), 7.91(\mathrm{~d}, J=8 \mathrm{~Hz}, 1 \mathrm{H}), 7.78(\mathrm{~d}, J=9 \mathrm{~Hz}, 1 \mathrm{H}), 7.72(\mathrm{~d}$, $J=9 \mathrm{~Hz}, 1 \mathrm{H}), 7.67(\mathrm{~d}, J=8 \mathrm{~Hz}, 2 \mathrm{H}), 7.62(\mathrm{~s}, 1 \mathrm{H}), 7.57(\mathrm{t}, J=8 \mathrm{~Hz}, 1 \mathrm{H}), 7.50(\mathrm{t}, J=8 \mathrm{~Hz}, 1 \mathrm{H}), 2.41(\mathrm{~s}$, $3 \mathrm{H}) ;{ }^{13} \mathrm{C}$ NMR $\left(125 \mathrm{MHz}, \mathrm{CDCl}_{3}\right) \delta 137.6,135.0,134.6,133.7,132.9,129.4,129.0,128.2,127.9,127.8$, $127.7,126.5,126.4,126.3,125.8,123.5,21.3$; HRMS (ESI-MS) $\mathrm{m} / z$ calcd for $\mathrm{C}_{15} \mathrm{H}_{15} \mathrm{~S}[\mathrm{M}+\mathrm{H}]^{+}: 275.0889$, found: 275.0882 ; $\mathrm{mp}: 120-122^{\circ} \mathrm{C}$. 
Synthesis of $\mathbf{2 d}$
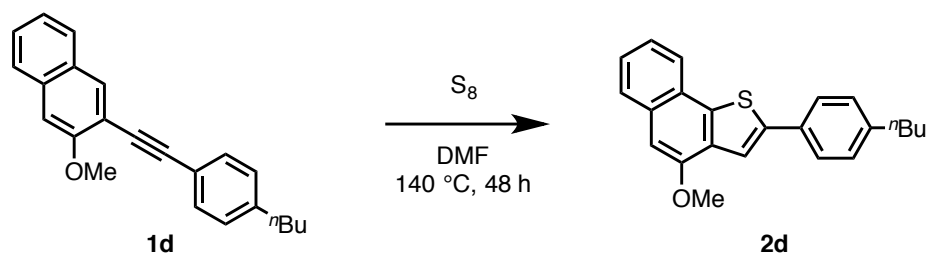

To a 10-mL Schlenk tube containing a magnetic stirring bar were added $\mathbf{1 d}(31.4 \mathrm{mg}, 100 \mu \mathrm{mol})$ and $\mathrm{S}_{8}(25.6$ $\mathrm{mg}, 100 \mu \mathrm{mol})$. The tube was filled with argon, then DMF $(1.0 \mathrm{~mL})$ was added to the tube and the mixture was heated at $140{ }^{\circ} \mathrm{C}$ for $48 \mathrm{~h}$. The mixture was then cooled to room temperature. The crude solution was concentrated in vacuo. The residue was subjected to PTLC $\left(\mathrm{CHCl}_{3} /\right.$ hexane/EtOAc $\left.=2: 20: 1\right)$ to afford $\mathbf{2 d}$ (27.6 mg, 80\% yield) as white solid.

${ }^{1} \mathrm{H}$ NMR $\left(500 \mathrm{MHz}, \mathrm{CDCl}_{3}\right) \delta 8.01(\mathrm{~s}, 1 \mathrm{H}), 7.73(\mathrm{t}, J=9 \mathrm{~Hz}, 2 \mathrm{H}), 7.51(\mathrm{~d}, J=8 \mathrm{~Hz}, 2 \mathrm{H}), 7.44(\mathrm{t}, J=7 \mathrm{~Hz}$, 1H), 7.35 (t, $J=7 \mathrm{~Hz}, 1 \mathrm{H}), 7.17(\mathrm{~d}, J=8 \mathrm{~Hz}, 2 \mathrm{H}), 7.13(\mathrm{~s}, 1 \mathrm{H}), 4.02(\mathrm{~s}, 3 \mathrm{H}), 2.63$ (t, $J=8 \mathrm{~Hz}, 2 \mathrm{H}), 1.62$ (quint, $J=7 \mathrm{~Hz}, 2 \mathrm{H}), 1.37$ (sext, $J=7 \mathrm{~Hz}, 2 \mathrm{H}), 0.94(\mathrm{t}, J=7 \mathrm{~Hz}, 3 \mathrm{H}) ;{ }^{13} \mathrm{C}$ NMR $\left(125 \mathrm{MHz}, \mathrm{CDCl}_{3}\right) 153.2$, 143.1, 143.0, 138.0, 132.4, 132.2, 131.8, 129.0, 127.6, 126.2, 125.8, 124.8, 124.2, 123.3, 116.8, 55.4, 35.4, 33.5, 22.4, 14.0; HRMS (ESI-MS) $\mathrm{m} / z$ calcd for $\mathrm{C}_{23} \mathrm{H}_{22} \mathrm{OS}[\mathrm{M}+\mathrm{H}]^{+}: 347.1464$, found: 347.1458; mp: 59.0$61.0^{\circ} \mathrm{C}$.

Synthesis of $2 e$
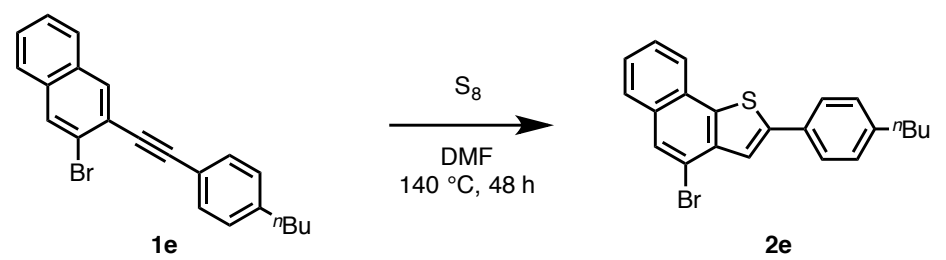

To a $10-\mathrm{mL}$ Schlenk tube containing a magnetic stirring bar were added $1 \mathrm{e}(660 \mathrm{mg}, 1.80 \mathrm{mmol})$ and $\mathrm{S}_{8}(461$ $\mathrm{mg}, 1.80 \mathrm{mmol})$. The tube was filled with argon, then DMF $(5.0 \mathrm{~mL})$ was added to the tube and the mixture was heated at $140{ }^{\circ} \mathrm{C}$ for $48 \mathrm{~h}$. The mixture was then cooled to room temperature. The crude solution was concentrated in vacuo. The residue was subjected to PTLC $\left(\mathrm{CHCl}_{3} /\right.$ hexane $\left.=1: 10\right)$ to afford $\mathbf{2 e}(403 \mathrm{mg}$, $56 \%$ yield) as white solid.

${ }^{1} \mathrm{H}$ NMR $\left(500 \mathrm{MHz}, \mathrm{CDCl}_{3}\right) \delta 8.03(\mathrm{~d}, J=8 \mathrm{~Hz}, 1 \mathrm{H}), 7.90(\mathrm{~s}, 1 \mathrm{H}), 7.79(\mathrm{~d}, J=8 \mathrm{~Hz}, 1 \mathrm{H}), 7.75(\mathrm{~s}, 1 \mathrm{H}), 7.68$ $(\mathrm{d}, J=9 \mathrm{~Hz}, 2 \mathrm{H}), 7.55(\mathrm{t}, J=8 \mathrm{~Hz}, 1 \mathrm{H}), 7.48(\mathrm{t}, J=8 \mathrm{~Hz}, 1 \mathrm{H}), 7.25(\mathrm{~d}, J=9 \mathrm{~Hz}, 2 \mathrm{H}), 2.66(\mathrm{t}, J=8 \mathrm{~Hz}, 2 \mathrm{H})$, 1.64 (quint, $J=7 \mathrm{~Hz}, 2 \mathrm{H}), 1.39$ (sext, $J=7 \mathrm{~Hz}, 2 \mathrm{H}), 0.95(\mathrm{t}, J=7 \mathrm{~Hz}, 3 \mathrm{H}) ;{ }^{13} \mathrm{C} \mathrm{NMR}\left(125 \mathrm{MHz}, \mathrm{CDCl}_{3}\right) \delta$ 144.0, 143.6, 138.0, 137.0, 131.5, 131.3, 129.1, 128.0, 127.9, 127.8, 126.9, 126.3, 126.2, 123.5, 120.5, 115.6, 35.4, 33.5, 22.4, 14.0; HRMS (ESI-MS) $\mathrm{m} / z$ calcd for $\mathrm{C}_{22} \mathrm{H}_{19} \mathrm{BrS}[\mathrm{M}+\mathrm{H}]^{+}: 395.0464$, found: 395.0457 ; mp: $74.0-75.0^{\circ} \mathrm{C}$. 
Synthesis of $2 f$
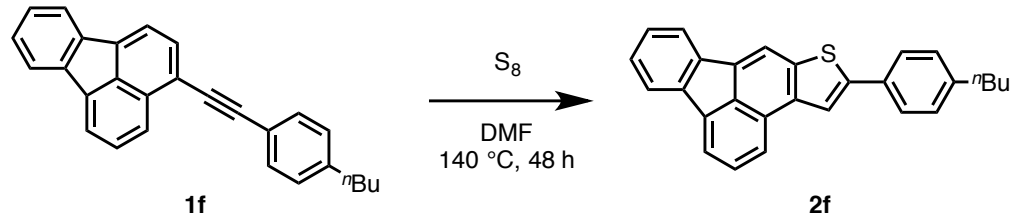

To a $10-\mathrm{mL}$ Schlenk tube containing a magnetic stirring bar were added $\mathbf{1 f}(35.5 \mathrm{mg}, 100 \mu \mathrm{mol})$ and $\mathrm{S}_{8}(25.7$ $\mathrm{mg}, 100 \mu \mathrm{mol})$. The tube was filled with argon, then DMF $(0.5 \mathrm{~mL})$ was added to the tube and the mixture was heated at $140{ }^{\circ} \mathrm{C}$ for $48 \mathrm{~h}$. The mixture was then cooled to room temperature. The crude solution was concentrated in vacuo. The residue was subjected to GPC to afford $\mathbf{2 f}$ (19.5 $\mathrm{mg}, 50 \%$ yield) as orange solid. ${ }^{1} \mathrm{H}$ NMR $\left(500 \mathrm{MHz}, \mathrm{CDCl}_{3}\right) \delta 8.30(\mathrm{~s}, 1 \mathrm{H}), 8.22(\mathrm{~d}, J=8 \mathrm{~Hz}, 1 \mathrm{H}), 8.18(\mathrm{~s}, 1 \mathrm{H}), 7.97(\mathrm{~d}, J=7.0 \mathrm{~Hz}, 1 \mathrm{H})$, 7.95-7.92 (m, 2H), 7.75-7.72 (m, 3H), 7.40-7.38 (m, 2H), $7.29(\mathrm{~d}, J=8 \mathrm{~Hz}, 2 \mathrm{H}), 2.68(\mathrm{t}, J=8 \mathrm{~Hz}, 2 \mathrm{H})$, 1.67 (quint, $J=7 \mathrm{~Hz}, 2 \mathrm{H}), 1.41(\mathrm{sext}, J=7 \mathrm{~Hz}, 2 \mathrm{H}), 0.97(\mathrm{t}, J=7 \mathrm{~Hz}, 3 \mathrm{H}) ;{ }^{13} \mathrm{C} \mathrm{NMR}\left(125 \mathrm{MHz}, \mathrm{CDCl}_{3}\right) \delta$ 145.6, 143.4, 140.6, 140.1, 139.2, 138.9, 137.02, 136.98, 133.7, 131.7, 131.0, 129.1, 128.0, 127.5, 127.4, 126.2, 126.0, 122.6, 121.5, 121.3, 119.0, 117.2, 115.3, 35.4, 33.5, 22.4, 14.0; HRMS (ESI-MS) $\mathrm{m} / z$ calcd for $\mathrm{C}_{28} \mathrm{H}_{22} \mathrm{~S}[\mathrm{M}+\mathrm{H}]^{+}: 391.1515$, found: $391.1507 ; \mathrm{mp}: 113-115^{\circ} \mathrm{C}$.

Synthesis of $\mathbf{2 g}$
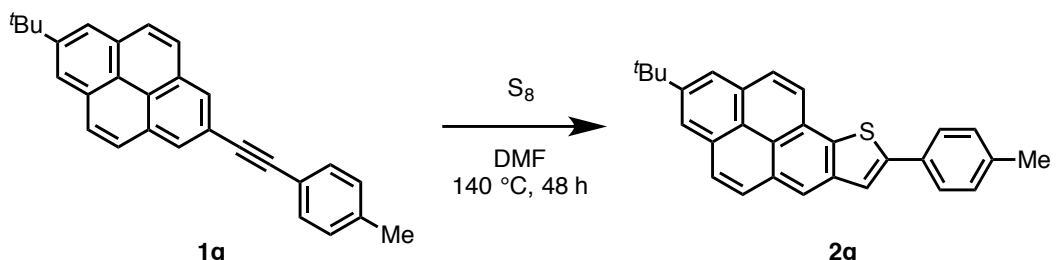

$2 g$

To a 10-mL Schlenk tube containing a magnetic stirring bar were added $\mathbf{1 f}(37.2 \mathrm{mg}, 100 \mu \mathrm{mol})$ and $\mathrm{S}_{8}(51.4$ $\mathrm{mg}, 200 \mu \mathrm{mol})$. The tube was filled with argon, then DMF $(1.0 \mathrm{~mL})$ was added to the tube and the mixture was heated at $140{ }^{\circ} \mathrm{C}$ for $48 \mathrm{~h}$. The mixture was then cooled to room temperature. The crude solution was concentrated in vacuo. The residue was subjected to PTLC $\left(\mathrm{CHCl}_{3} /\right.$ hexane $\left.=1: 10\right)$ and $\mathrm{GPC}$ to afford $\mathbf{2 f}$ (20.0 mg, 50\% yield) as white solid.

${ }^{1} \mathrm{H} \mathrm{NMR}\left(500 \mathrm{MHz}, \mathrm{CDCl}_{3}\right) \delta 8.45(\mathrm{~s}, 1 \mathrm{H}), 8.34(\mathrm{~d}, J=9 \mathrm{~Hz}, 1 \mathrm{H}), 8.23(\mathrm{~d}, J=1 \mathrm{~Hz}, 1 \mathrm{H}), 8.20(\mathrm{~d}, J=9 \mathrm{~Hz}$, 1H), $8.19(\mathrm{~s}, 1 \mathrm{H}), 8.04(\mathrm{~d}, J=9 \mathrm{~Hz}, 1 \mathrm{H}), 7.96(\mathrm{~d}, J=9 \mathrm{~Hz}, 1 \mathrm{H}), 7.89(\mathrm{~s}, 1 \mathrm{H}), 7.77(\mathrm{~d}, J=8 \mathrm{~Hz}, 2 \mathrm{H}), 7.30(\mathrm{~d}$, $J=8 \mathrm{~Hz}, 2 \mathrm{H}), 2.44$ (s, 3H), 1.60 (s, 9H); ${ }^{13} \mathrm{C} \mathrm{NMR}\left(125 \mathrm{MHz}, \mathrm{CDCl}_{3}\right) \delta 148.8,144.3,138.8,138.4,134.9$, 131.6, 131.0, 130.8, 129.7, 129.1, 128.2, 127.8, 126.9, 126.6, 125.3, 123.4, 122.5, 122.4, 122.1, 119.7, 119.3, 35.2, 31.9, 21.3; HRMS (ESI-MS) $\mathrm{m} / z$ calcd for $\mathrm{C}_{29} \mathrm{H}_{24} \mathrm{~S}[\mathrm{M}+\mathrm{H}]^{+}: 405.1671$, found: 405.1666; mp: 241$243^{\circ} \mathrm{C}$. 
Synthesis of $\mathbf{2 h}$
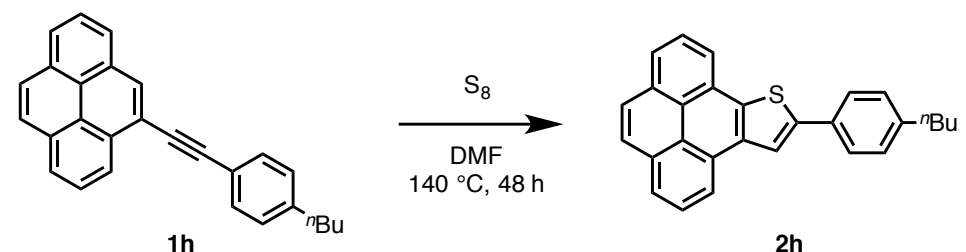

$2 \mathrm{~h}$

To a $10-\mathrm{mL}$ Schlenk tube containing a magnetic stirring bar were added $\mathbf{1 h}(36.5 \mathrm{mg}, 100 \mu \mathrm{mol})$ and $\mathrm{S}_{8}$ (25.6 mg, $100 \mu \mathrm{mol})$. The tube was filled with argon, then DMF $(0.5 \mathrm{~mL})$ was added to the tube and the mixture was heated at $140{ }^{\circ} \mathrm{C}$ for $48 \mathrm{~h}$. The mixture was then cooled to room temperature. The crude solution was concentrated in vacuo. The residue was subjected to PTLC $\left(\mathrm{CHCl}_{3} /\right.$ hexane $\left.=1: 10\right)$ to afford $\mathbf{2 h}(28.5 \mathrm{mg}$, $72 \%$ yield) as white solid.

${ }^{1} \mathrm{H}$ NMR $\left(500 \mathrm{MHz}, \mathrm{CDCl}_{3}\right) \delta 8.61(\mathrm{~d}, J=8 \mathrm{~Hz}, 1 \mathrm{H}), 8.40(\mathrm{~d}, J=7 \mathrm{~Hz}, 1 \mathrm{H}), 8.30(\mathrm{~s}, 1 \mathrm{H}), 8.18(\mathrm{~d}, J=7 \mathrm{~Hz}$, $1 \mathrm{H}), 8.15(\mathrm{~d}, J=8 \mathrm{~Hz}, 1 \mathrm{H}), 8.10-8.00(\mathrm{~m}, 4 \mathrm{H}), 7.80(\mathrm{~d}, J=8 \mathrm{~Hz}, 2 \mathrm{H}), 7.32(\mathrm{~d}, J=8 \mathrm{~Hz}, 2 \mathrm{H}), 2.70(\mathrm{t}, J=8$ $\mathrm{Hz}, 2 \mathrm{H}), 1.68$ (quint, $J=7 \mathrm{~Hz}, 2 \mathrm{H}), 1.43(\mathrm{sext}, J=7 \mathrm{~Hz}, 2 \mathrm{H}), 0.98(\mathrm{t}, J=7 \mathrm{~Hz}, 3 \mathrm{H}) ;{ }^{13} \mathrm{C}$ NMR $(125 \mathrm{MHz}$, $\left.\mathrm{CDCl}_{3}\right) \delta 143.9,143.1,136.3,135.9,131.75,131.72,129.1,127.7,127.3,126.14,126.08,125.9,125.0$, $124.8,123.4,122.9,121.0,120.5,118.4,35.4,33.5,22.4,14.0$; HRMS (ESI-MS) $\mathrm{m} / \mathrm{z}$ calcd for $\mathrm{C}_{28} \mathrm{H}_{22} \mathrm{~S}$ $[\mathrm{M}+\mathrm{H}]^{+}: 391.1515$, found: 391.1508 ; mp: $134-136^{\circ} \mathrm{C}$.

Synthesis of $2 i$

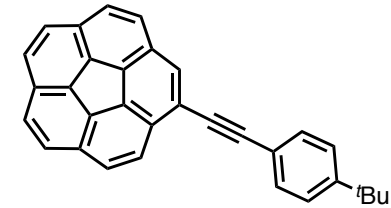

$1 \mathbf{i}$

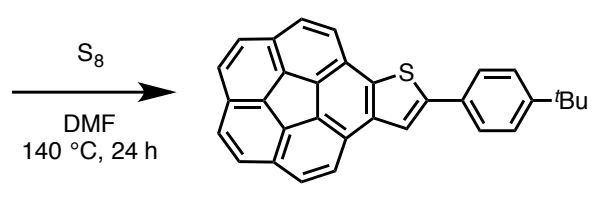

2i

To a $10-\mathrm{mL}$ Schlenk tube containing a magnetic stirring bar were added $\mathbf{1 i}(40.6 \mathrm{mg}, 100 \mu \mathrm{mol})$ and $\mathrm{S}_{8}(12.8$ $\mathrm{mg}, 50.0 \mu \mathrm{mol})$. The tube was filled with argon, then DMF $(2.0 \mathrm{~mL})$ was added to the tube and the mixture was heated at $140^{\circ} \mathrm{C}$ for $24 \mathrm{~h}$. The mixture was then cooled to room temperature. The crude solution was concentrated in vacuo. The residue was subjected to PTLC $\left(\mathrm{CHCl}_{3} /\right.$ hexane $\left.=1: 10\right)$ to afford $2 \mathbf{i}(43.6 \mathrm{mg}$, $99 \%$ yield) as white solid.

${ }^{1} \mathrm{H}$ NMR $\left(500 \mathrm{MHz}, \mathrm{CDCl}_{3}\right) \delta 8.20(\mathrm{~s}, 1 \mathrm{H}), 8.07(\mathrm{~d}, J=9 \mathrm{~Hz}, 1 \mathrm{H}), 7.95(\mathrm{~d}, J=9 \mathrm{~Hz}, 1 \mathrm{H}), 7.88(\mathrm{~d}, J=9 \mathrm{~Hz}$, $1 \mathrm{H}), 7.86(\mathrm{~d}, J=9 \mathrm{~Hz}, 1 \mathrm{H}), 7,82-7.76(\mathrm{~m}, 6 \mathrm{H}), 7.52(\mathrm{~d}, J=9 \mathrm{~Hz}, 1 \mathrm{H}), 1.40(\mathrm{~s}, 9 \mathrm{H}) ;{ }^{13} \mathrm{C}$ NMR $(125 \mathrm{MHz}$, $\left.\mathrm{CDCl}_{3}\right) \delta 151.5,144.6,138.6,136.5,136.0,135.55,135.48,134.4,133.6,131.5,130.8,129.9,129.6,127.8$, $127.7,127.5,127.1,127.0,126.71,126.68,126.03,125.98,124.8,124.5,118.2,34.7,31.3$; HRMS (ESI-MS) $\mathrm{m} / \mathrm{z}$ calcd for $\mathrm{C}_{32} \mathrm{H}_{22} \mathrm{~S}[\mathrm{M}+\mathrm{H}]^{+}: 439.1515$, found: 439.1508 ; mp: $135-137^{\circ} \mathrm{C}$. 
Synthesis of $\mathbf{2} \boldsymbol{j}$

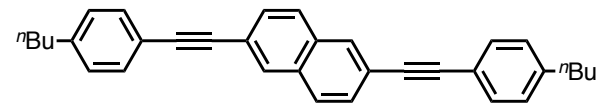

$1 \mathrm{j}$

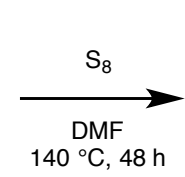

$140^{\circ} \mathrm{C}, 48 \mathrm{~h}$

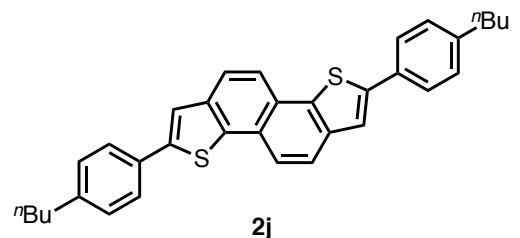

2j

To a $10-\mathrm{mL}$ Schlenk tube containing a magnetic stirring bar were added $\mathbf{1 j}(44.0 \mathrm{mg}, 100 \mu \mathrm{mol})$ and $\mathrm{S}_{8}(102$ $\mathrm{mg}, 400 \mu \mathrm{mol})$. The tube was filled with argon, then DMF $(1.0 \mathrm{~mL})$ was added to the tube and the mixture was heated at $140{ }^{\circ} \mathrm{C}$ for $48 \mathrm{~h}$. The mixture was then cooled to room temperature. The crude solution was concentrated in vacuo. The residue was subjected to PTLC $\left(\mathrm{CHCl}_{3} /\right.$ hexane $\left.=1: 5\right)$ to afford $\mathbf{2 \mathbf { j }}(12.7 \mathrm{mg}, 25 \%$ yield) as white solid.

${ }^{1} \mathrm{H}$ NMR $\left(500 \mathrm{MHz}, \mathrm{CDCl}_{3}\right) \delta 8.01(\mathrm{~d}, J=9 \mathrm{~Hz}, 2 \mathrm{H}), 7.87(\mathrm{~d}, J=9 \mathrm{~Hz}, 2 \mathrm{H}), 7.70(\mathrm{~d}, J=8 \mathrm{~Hz}, 4 \mathrm{H}), 7.65$ (s, $2 \mathrm{H}), 7.27(\mathrm{~d}, J=8 \mathrm{~Hz}, 4 \mathrm{H}), 2.67(\mathrm{t}, J=8 \mathrm{~Hz}, 2 \mathrm{H}), 1.66$ (quint, $J=7 \mathrm{~Hz}, 2 \mathrm{H}), 1.41$ (sext, $J=7 \mathrm{~Hz}, 2 \mathrm{H}), 0.97$ $(\mathrm{t}, J=7 \mathrm{~Hz}, 3 \mathrm{H}) ;{ }^{13} \mathrm{C}$ NMR $\left(125 \mathrm{MHz}, \mathrm{C}_{2} \mathrm{D}_{2} \mathrm{Cl}_{4}\right) \delta 143.5,143.3,138.1,137.5,131.3,129.0,126.1,125.5$, 122.6, 121.2, 120.1, 35.3, 33.4, 22.3, 14.0; HRMS (ESI-MS) $\mathrm{m} / z$ calcd for $\mathrm{C}_{34} \mathrm{H}_{32} \mathrm{~S}_{2}[\mathrm{M}+\mathrm{H}]^{+}: 505.2018$, found: 505.2010 ; mp: $202-204{ }^{\circ} \mathrm{C}$.

Synthesis of $\mathbf{2 k}$

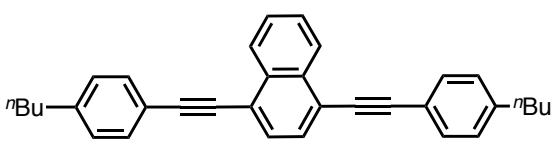

$1 \mathrm{k}$
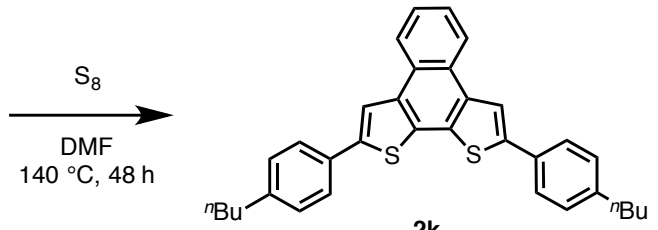

To a $10-\mathrm{mL}$ Schlenk tube containing a magnetic stirring bar were added $\mathbf{1 k}(44.0 \mathrm{mg}, 100 \mu \mathrm{mol})$ and $\mathrm{S}_{8}$ $(51.0 \mathrm{mg}, 200 \mu \mathrm{mol})$. The tube was filled with argon, then DMF $(1.0 \mathrm{~mL})$ was added to the tube and the mixture was heated at $140{ }^{\circ} \mathrm{C}$ for $48 \mathrm{~h}$. The mixture was then cooled to room temperature. The crude solution was concentrated in vacuo. The residue was subjected to PTLC $\left(\mathrm{CHCl}_{3} /\right.$ hexane $\left.=1: 5\right)$ to afford $\mathbf{2 k}(22.5 \mathrm{mg}$, $44 \%$ yield) as orange solid.

${ }^{1} \mathrm{H}$ NMR $\left(500 \mathrm{MHz}, \mathrm{CDCl}_{3}\right) \delta 8.38(\mathrm{dd}, J=6,3 \mathrm{~Hz}, 2 \mathrm{H}), 8.14(\mathrm{~s}, 2 \mathrm{H}), 7.72(\mathrm{~d}, J=8 \mathrm{~Hz}, 4 \mathrm{H}), 7.63(\mathrm{dd}, J=6$, $3 \mathrm{~Hz}, 2 \mathrm{H}), 7.28(\mathrm{~d}, J=8 \mathrm{~Hz}, 4 \mathrm{H}), 2.68(\mathrm{t}, J=8 \mathrm{~Hz}, 4 \mathrm{H}), 1.67$ (quint, $J=7 \mathrm{~Hz}, 4 \mathrm{H}), 1.42$ (sext, $J=7 \mathrm{~Hz}, 4 \mathrm{H}$ ), $0.97(\mathrm{t}, J=7 \mathrm{~Hz}, 6 \mathrm{H}) ;{ }^{13} \mathrm{C} \mathrm{NMR}\left(125 \mathrm{MHz}, \mathrm{CDCl}_{3}\right) \delta 143.0,142.2,135.0,131.6,131.0,129.0,127.5,126.0$, 125.6, 124.3, 117.6, 35.4, 33.5, 22.4, 14.0; HRMS (ESI-MS) $\mathrm{m} / z$ calcd for $\mathrm{C}_{34} \mathrm{H}_{32} \mathrm{~S}_{2}[\mathrm{M}+\mathrm{H}]^{+}: 505.2018$, found: 505.2008 ; mp: $162-164{ }^{\circ} \mathrm{C}$. 
Synthesis of $\mathbf{2 l}$
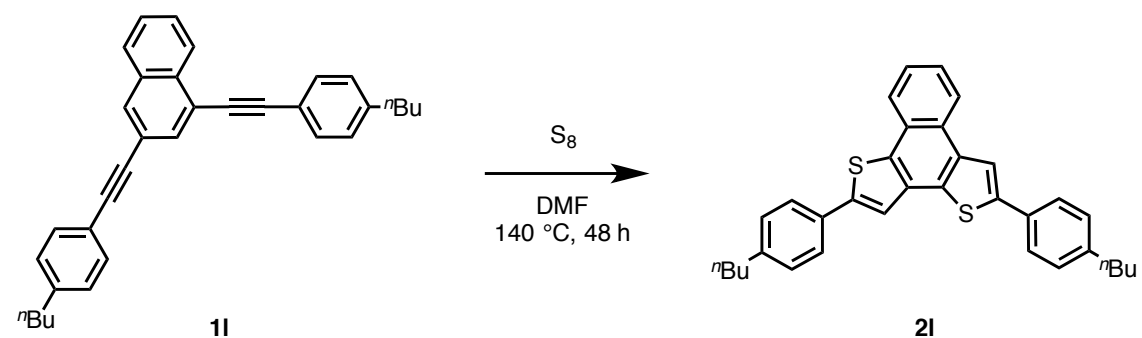

2I

To a 10-mL Schlenk tube containing a magnetic stirring bar were added $\mathbf{1 l}$ (44.0 mg, $100 \mu \mathrm{mol})$ and $\mathrm{S}_{8}(102$ $\mathrm{mg}, 400 \mu \mathrm{mol})$. The tube was filled with argon, then DMF $(1.0 \mathrm{~mL})$ was added to the tube and the mixture was heated at $140{ }^{\circ} \mathrm{C}$ for $48 \mathrm{~h}$. The mixture was then cooled to room temperature. The crude solution was concentrated in vacuo. The residue was subjected to silica-gel chromatography $\left(\mathrm{CHCl}_{3} /\right.$ hexane $\left.=1: 20\right)$ and GPC to afford 21 (30.0 $\mathrm{mg}, 59 \%$ yield) as white solid.

${ }^{1} \mathrm{H}$ NMR $\left(500 \mathrm{MHz}, \mathrm{CDCl}_{3}\right) \delta 8.33(\mathrm{~d}, J=8 \mathrm{~Hz}, 1 \mathrm{H}), 8.12(\mathrm{~d}, J=8 \mathrm{~Hz}, 1 \mathrm{H}), 8.11(\mathrm{~s}, 1 \mathrm{H}), 7.72(\mathrm{~s}, 1 \mathrm{H}), 7.71$ $(\mathrm{d}, J=7 \mathrm{~Hz}, 4 \mathrm{H}), 7.58-7.40(\mathrm{~m}, 2 \mathrm{H}), 7.26(\mathrm{~d}, J=7 \mathrm{~Hz}, 4 \mathrm{H}), 2.67(\mathrm{t}, J=8 \mathrm{~Hz}, 4 \mathrm{H}), 1.66$ (quint, $J=7 \mathrm{~Hz}$, $4 \mathrm{H}), 1.41$ (sext, $J=7 \mathrm{~Hz}, 4 \mathrm{H}), 0.97(\mathrm{t}, J=7 \mathrm{~Hz}, 6 \mathrm{H}) ;{ }^{13} \mathrm{C}$ NMR $\left(125 \mathrm{MHz}, \mathrm{CDCl}_{3}\right) \delta 144.8,143.4,143.0$, 142.5, 135.4, 133.9, 132.9, 132.2, 131.8, 131.5, 129.1, 127.3, 127.1, 126.2, 126.1, 125.94, 125.89, 124.6, $124.2,117.7,117.5,35.4,33.5,22.4,14.0$; HRMS (ESI-MS) $\mathrm{m} / \mathrm{z}$ calcd for $\mathrm{C}_{34} \mathrm{H}_{32} \mathrm{~S}_{2}[\mathrm{M}+\mathrm{H}]^{+}: 505.2018$, found: 505.2010 ; mp: $143-145^{\circ} \mathrm{C}$.

\section{Synthesis of $\mathbf{2 m}$}
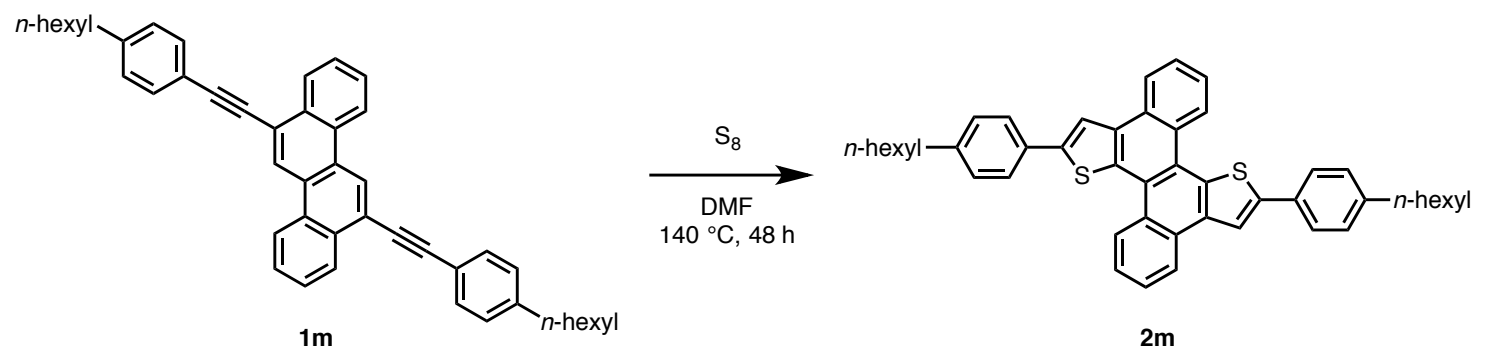

To a $10-\mathrm{mL}$ Schlenk tube containing a magnetic stirring bar were added $\mathbf{1 m}(59.6 \mathrm{mg}, 100 \mu \mathrm{mol})$ and $\mathrm{S}_{8}$ (51.0 mg, $200 \mu \mathrm{mol})$. The tube was filled with argon, then DMF $(2.0 \mathrm{~mL})$ was added to the tube and the mixture was heated at $140{ }^{\circ} \mathrm{C}$ for $48 \mathrm{~h}$. The mixture was then cooled to room temperature. The crude solution was concentrated in vacuo. The residue was subjected to PTLC $\left(\mathrm{CHCl}_{3} /\right.$ hexane $\left.=2: 5\right)$ to afford $\mathbf{2 m}(57.9 \mathrm{mg}$, $88 \%$ yield) as orange solid.

${ }^{1} \mathrm{H}$ NMR $\left(500 \mathrm{MHz}, \mathrm{CDCl}_{3}\right) \delta 9.36(\mathrm{dd}, J=8,2 \mathrm{~Hz}, 2 \mathrm{H}), 8.50(\mathrm{dd}, J=8,2 \mathrm{~Hz}, 2 \mathrm{H}), 8.22(\mathrm{~s}, 2 \mathrm{H}), 7.79(\mathrm{~d}, J$ $=8 \mathrm{~Hz}, 4 \mathrm{H}), 7.79-7.75(\mathrm{~m}, 4 \mathrm{H}), 7.29(\mathrm{~d}, J=8 \mathrm{~Hz}, 4 \mathrm{H}), 2.68(\mathrm{t}, J=7 \mathrm{~Hz}, 4 \mathrm{H}), 1.69$ (quint, $J=7 \mathrm{~Hz}, 4 \mathrm{H}$ ), $1.43-1.31(\mathrm{~m}, 12 \mathrm{H}), 0.92(\mathrm{t}, J=7 \mathrm{~Hz}, 6 \mathrm{H}) ;{ }^{13} \mathrm{C} \mathrm{NMR}\left(125 \mathrm{MHz}, \mathrm{CDCl}_{3}\right) \delta$ 144.0, 143.2, 136.4, 133.9, 131.4, $129.0,128.8,128.6,126.8,126.1,126.0,124.6,124.1,117.2,35.8,31.8,31.4,29.0,22.6,14.1$; HRMS (ESI-MS) $m / z$ calcd for $\mathrm{C}_{46} \mathrm{H}_{44} \mathrm{~S}_{2}[\mathrm{M}+\mathrm{H}]^{+}: 661.2957$, found: 661.2937; mp: 205-207 ${ }^{\circ} \mathrm{C}$. 
Synthesis of $2 n$

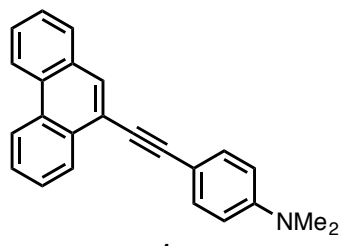

1n

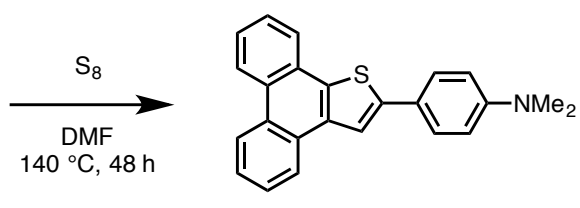

$2 n$

To a $10-\mathrm{mL}$ Schlenk tube containing a magnetic stirring bar were added $\mathbf{1 n}(83.0 \mathrm{mg}, 259 \mu \mathrm{mol})$ and $\mathrm{S}_{8}$ (66.3 $\mathrm{mg}, 259 \mu \mathrm{mol})$. The tube was filled with argon, then DMF $(1.0 \mathrm{~mL})$ was added to the tube and the mixture was heated at $140{ }^{\circ} \mathrm{C}$ for $48 \mathrm{~h}$. The mixture was then cooled to room temperature. The crude solution was concentrated in vacuo. The residue was subjected to PTLC $\left(\mathrm{CHCl}_{3} /\right.$ hexane $\left.=1: 10\right)$ and $\mathrm{GPC}$ to afford $\mathbf{2 n}$ (70.0 mg, 77\% yield) as white solid.

${ }^{1} \mathrm{H}$ NMR (500 MHz, $\left.\mathrm{CDCl}_{3}\right)$ d 8.71-8.67 (m, 2H), 8.35-8.34 (m, 1H), 8.13-8.10 (m, 1H), 8.00 (s, 1H), 7.71 $(\mathrm{d}, J=9 \mathrm{~Hz}, 2 \mathrm{H}), 7.68-7.58(\mathrm{~m}, 4 \mathrm{H}), 6.82(\mathrm{~d}, J=8 \mathrm{~Hz}, 2 \mathrm{H}), 3.04(\mathrm{~s}, 6 \mathrm{H}) ;{ }^{13} \mathrm{C} \mathrm{NMR}\left(125 \mathrm{MHz}, \mathrm{CDCl}_{3}\right) \delta$ 150.3, 144.4, 136.1, 134.6, 129.1, 128.7, 128.3, 128.2, 127.14, 127.10, 125.8, 125.7, 124.2, 124.0, 123.5, $123.4,122.5,116.1,112.4,40.4$; HRMS (MALDI-TOF-MS) $\mathrm{m} / \mathrm{z}$ calcd for $\mathrm{C}_{24} \mathrm{H}_{19} \mathrm{NS}[\mathrm{M}]^{+}: 353.1233$, found: 353.1208; mp: $170-172{ }^{\circ} \mathrm{C}$.

\section{Synthesis of 20}

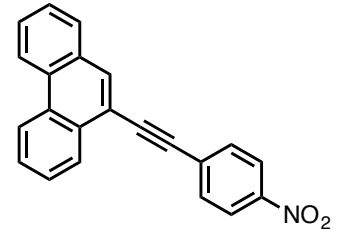

10

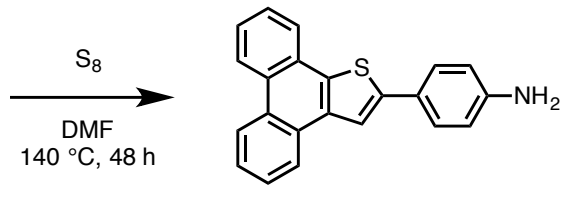

20

To a $10-\mathrm{mL}$ Schlenk tube containing a magnetic stirring bar were added $10(162 \mathrm{mg}, 500 \mu \mathrm{mol})$ and $\mathrm{S}_{8}(128$ $\mathrm{mg}, 500 \mu \mathrm{mol})$. The tube was filled with argon, then DMF $(3.0 \mathrm{~mL})$ was added to the tube and the mixture was heated at $140{ }^{\circ} \mathrm{C}$ for $48 \mathrm{~h}$. The mixture was then cooled to room temperature. The crude solution was concentrated in vacuo. The residue was subjected to PTLC $\left(\mathrm{CHCl}_{3} /\right.$ hexane/EtOAc $\left.=2: 5: 1\right)$ and GPC to afford 20 ( $85.0 \mathrm{mg}, 52 \%$ yield) as white solid.

${ }^{1} \mathrm{H} \mathrm{NMR}\left(500 \mathrm{MHz}, \mathrm{CDCl}_{3}\right) \delta 8.69(\mathrm{t}, J=9 \mathrm{~Hz}, 2 \mathrm{H}), 8.34(\mathrm{~d}, J=7 \mathrm{~Hz}, 1 \mathrm{H}), 8.10(\mathrm{~d}, J=7 \mathrm{~Hz}, 1 \mathrm{H}), 8.00(\mathrm{~s}$, 1H), 7.67-7.58 (m, 6H), $6.77(\mathrm{~d}, J=9 \mathrm{~Hz}, 2 \mathrm{H}), 3.83(\mathrm{~s}, 2 \mathrm{H}) ;{ }^{13} \mathrm{C} \mathrm{NMR}\left(125 \mathrm{MHz}, \mathrm{CDCl}_{3}\right) \delta$ 146.6, 144.1, 136.1, 134.9, 129.1, 128.7, 128.35, 128.31, 127.47, 127.46, 127.2, 127.0, 125.9, 124.9, 124.2, 124.0, 123.6, 123.5, 116.7, 115.3; HRMS (MALDI-TOF-MS) $\mathrm{m} / z$ calcd for $\mathrm{C}_{22} \mathrm{H}_{15} \mathrm{NS}$ [M] ${ }^{+}: 325.0920$, found: 325.09051 ; mp: $194-196^{\circ} \mathrm{C}$. 
Synthesis of $2 p$
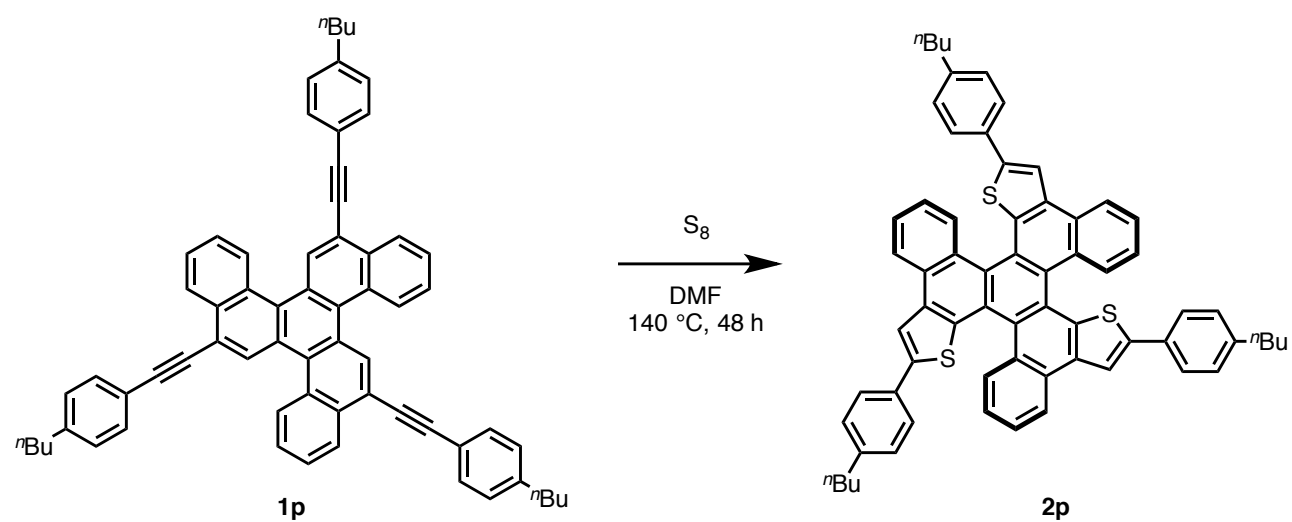

To a $10-\mathrm{mL}$ Schlenk tube containing a magnetic stirring bar were added $1 \mathbf{p}(84.6 \mathrm{mg}, 100 \mu \mathrm{mol})$ and $\mathrm{S}_{8}$ $(77.0 \mathrm{mg}, 300 \mu \mathrm{mol})$. The tube was filled with argon, then DMF $(3.0 \mathrm{~mL})$ was added to the tube and the mixture was heated at $140{ }^{\circ} \mathrm{C}$ for $48 \mathrm{~h}$. The mixture was then cooled to room temperature. The crude solution was concentrated in vacuo. The residue was subjected to PTLC $\left(\mathrm{CHCl}_{3} /\right.$ hexane $\left.=1: 5\right)$ and GPC to afford $\mathbf{2 p}$ (30.5 mg, $32 \%$ yield) as orange solid.

${ }^{1} \mathrm{H}$ NMR $\left(500 \mathrm{MHz}, \mathrm{CDCl}_{3}\right) \delta 8.72(\mathrm{~d}, J=8 \mathrm{~Hz}, 3 \mathrm{H}), 8.41(\mathrm{~d}, J=8 \mathrm{~Hz}, 3 \mathrm{H}), 8.03(\mathrm{~s}, 3 \mathrm{H}), 7.71(\mathrm{t}, J=7 \mathrm{~Hz}$, $3 \mathrm{H}), 7.56(\mathrm{~d}, J=8 \mathrm{~Hz}, 6 \mathrm{H}), 7.40(\mathrm{t}, J=8 \mathrm{~Hz}, 3 \mathrm{H}), 7.19(\mathrm{~d}, J=8 \mathrm{~Hz}, 6 \mathrm{H}), 2.62$ (t, $J=8 \mathrm{~Hz}, 6 \mathrm{H}), 1.62$ (quint, $J=8 \mathrm{~Hz}, 6 \mathrm{H}), 1.38(\mathrm{sext}, J=7 \mathrm{~Hz}, 6 \mathrm{H}), 0.94(\mathrm{t}, J=7 \mathrm{~Hz}, 9 \mathrm{H}) ;{ }^{13} \mathrm{C}$ NMR $\left(125 \mathrm{MHz}, \mathrm{CDCl}_{3}\right) \delta 143.6,143.0$, 137.0, 136.3, 132.0, 131.4, 128.9, 128.7, 128.0, 127.6, 126.6, 126.2, 125.2, 123.9, 123.1, 116.5, 35.3, 33.5, 22.3, 13.9; HRMS (ESI-MS) $m / z$ calcd for $\mathrm{C}_{66} \mathrm{H}_{54} \mathrm{~S}_{3}[\mathrm{M}+\mathrm{H}]^{+}$: 943.3460 , found: $943.3445 ; \mathrm{mp}: 190-192{ }^{\circ} \mathrm{C}$. 
Synthesis of $\mathbf{2 q}$

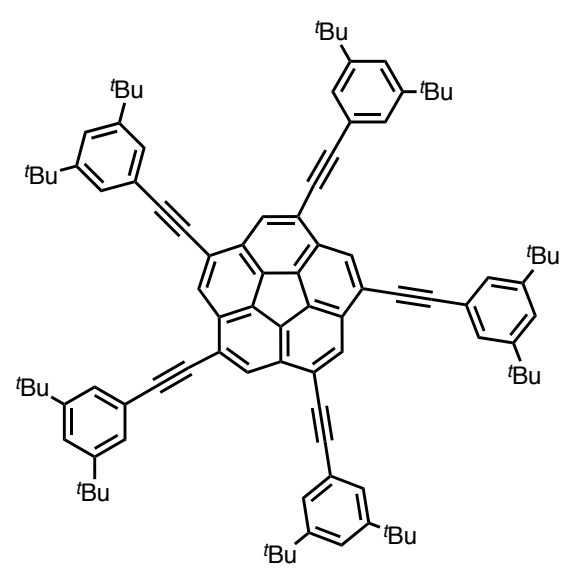

$1 q$

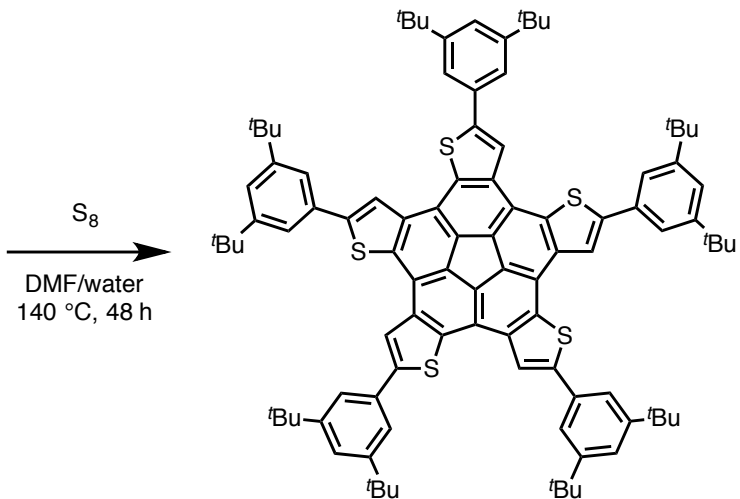

$2 q$

To a 50-mL Schlenk flask containing a magnetic stirring bar were added $\mathbf{1 q}(260 \mathrm{mg}, 200 \mu \mathrm{mol})$ and $\mathrm{S}_{8}(256$ $\mathrm{mg}, 1.00 \mathrm{mmol})$. The flask was filled with argon, then DMF $(10 \mathrm{~mL})$ and water $(1.0 \mathrm{~mL})$ were added to the flask and the mixture was heated at $140{ }^{\circ} \mathrm{C}$ for $48 \mathrm{~h}$. The mixture was then cooled to room temperature. The crude solution was concentrated in vacuo. The residue was subjected to GPC to afford $\mathbf{2 q}(57.0 \mathrm{mg}, 20 \%$ yield) as yellow solid.

${ }^{1} \mathrm{H}$ NMR (500 MHz, CDCl $) \delta 8.73(\mathrm{~s}, 5 \mathrm{H}), 7.85(\mathrm{~d}, J=2 \mathrm{~Hz}, 10 \mathrm{H}), 7.55(\mathrm{~d}, J=2 \mathrm{~Hz}, 5 \mathrm{H}), 1.49(\mathrm{~s}, 90 \mathrm{H})$; ${ }^{13} \mathrm{C}$ NMR $\left(125 \mathrm{MHz}, \mathrm{CDCl}_{3}\right) \delta 151.8,146.2,136.7,135.5,133.6,131.8,122.9,122.6,121.3,120.2,35.1$, 31.4. HRMS (MALDI-TOF-MS) $\mathrm{m} / z$ calcd for $\mathrm{C}_{100} \mathrm{H}_{110} \mathrm{~S}_{5}[\mathrm{M}]^{+}: 1470.721$, found: 1470.720 ; $\mathrm{mp}:>250{ }^{\circ} \mathrm{C}$.

Synthesis of $\mathbf{2 r}$
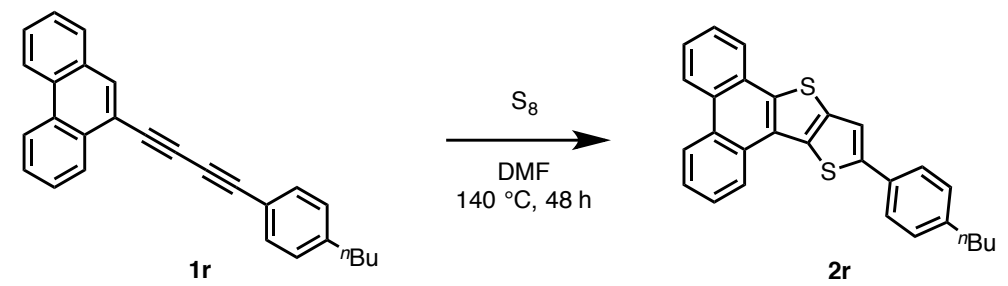

To a $10-\mathrm{mL}$ Schlenk tube containing a magnetic stirring bar were added $1 \mathbf{r}(35.6 \mathrm{mg}, 100 \mu \mathrm{mol})$ and $\mathrm{S}_{8}(102$ $\mathrm{mg}, 400 \mu \mathrm{mol})$. The tube was filled with argon, then DMF $(1.0 \mathrm{~mL})$ were added to the tube and the mixture was heated at $140{ }^{\circ} \mathrm{C}$ for $48 \mathrm{~h}$. The mixture was then cooled to room temperature. The crude solution was concentrated in vacuo. The residue was subjected to GPC to afford $2 \mathbf{r}(15.3 \mathrm{mg}, 36 \%$ yield) as white solid. ${ }^{1} \mathrm{H}$ NMR $\left(500 \mathrm{MHz}, \mathrm{CDCl}_{3}\right) \delta 8.78(\mathrm{~d}, J=8 \mathrm{~Hz}, 1 \mathrm{H}), 8.73-8.71(\mathrm{~m}, 1 \mathrm{H}), 8.46(\mathrm{~d}, J=8 \mathrm{~Hz}, 1 \mathrm{H}), 8.14-8.12$ $(\mathrm{m}, 1 \mathrm{H}), 7.81(\mathrm{t}, J=7 \mathrm{~Hz}, 1 \mathrm{H}), 7.72(\mathrm{t}, J=7 \mathrm{~Hz}, 1 \mathrm{H}), 7,68(\mathrm{~d}, J=8 \mathrm{~Hz}, 2 \mathrm{H}), 7.67-7.63(\mathrm{~m}, 1 \mathrm{H}), 7.26(\mathrm{~d}, J=$ $8 \mathrm{~Hz}, 1 \mathrm{H}), 2.68(\mathrm{t}, J=8 \mathrm{~Hz}, 2 \mathrm{H}), 1.67$ (quint, $J=7 \mathrm{~Hz}, 2 \mathrm{H}), 1.42(\mathrm{sext}, J=7 \mathrm{~Hz}, 2 \mathrm{H}), 0.97(\mathrm{t}, J=7 \mathrm{~Hz}, 3 \mathrm{H}$ ); ${ }^{13} \mathrm{C}$ NMR $\left(125 \mathrm{MHz}, \mathrm{C}_{2} \mathrm{D}_{2} \mathrm{Cl}_{4}\right) \delta 147.3,143.2,138.6,137.9,133.7,131.5,129.1,128.9,128.6,128.3,127.8$, $127.5,127.4,127.0,126.5,126.2,125.7,124.4,123.8,123.6,115.2,35.3,33.4,22.4,14.0$. HRMS (MALDI-TOF-MS) $\mathrm{m} / \mathrm{z}$ calcd for $\mathrm{C}_{28} \mathrm{H}_{22} \mathrm{~S}_{2}[\mathrm{M}]^{+}: 422.1157$, found: $422.1148 ; \mathrm{mp}: 218-220{ }^{\circ} \mathrm{C}$. 
Synthesis of $2 \mathrm{~s}$
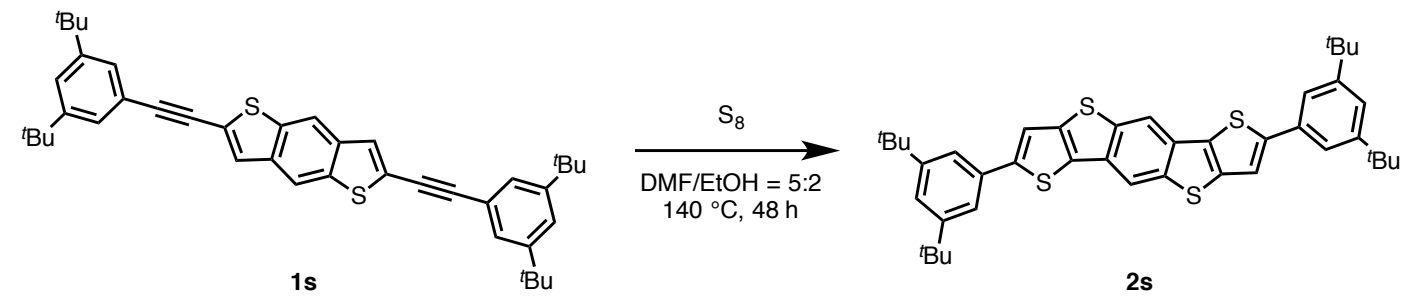

2s

To a $10-\mathrm{mL}$ Schlenk tube containing a magnetic stirring bar were added $1 \mathrm{~s}(149 \mathrm{mg}, 240 \mu \mathrm{mol})$ and $\mathrm{S}_{8}(123$ $\mathrm{mg}, 480 \mu \mathrm{mol})$ were added. The tube was filled with argon, then DMF $(3.0 \mathrm{~mL})$ and EtOH $(1.2 \mathrm{~mL})$ were added to the tube and the mixture was heated at $140{ }^{\circ} \mathrm{C}$ for $48 \mathrm{~h}$. The mixture was then cooled to room temperature. The crude solution was concentrated in vacuo. The residue was subjected to GPC to afford $2 \mathrm{~s}$ (46.3 mg, 28\% yield) as yellow solid.

${ }^{1} \mathrm{H}$ NMR $\left(500 \mathrm{MHz}, \mathrm{CDCl}_{3}\right) \delta 8.27(\mathrm{~s}, 2 \mathrm{H}), 7.55(\mathrm{~s}, 2 \mathrm{H}), 7.53(\mathrm{~d}, J=2 \mathrm{~Hz}, 4 \mathrm{H}), 7.44(\mathrm{t}, J=2 \mathrm{~Hz}, 2 \mathrm{H}), 1.40$ (s, 36H); ${ }^{13} \mathrm{C}$ NMR $\left(125 \mathrm{MHz}, \mathrm{CDCl}_{3}\right) \delta 151.7,148.8,140.1,139.0,133.8,132.7,130.4,122.7,120.6,116.3$, 115.4, 35.1, 31.5; HRMS (MALDI-TOF-MS) $\mathrm{m} / \mathrm{z}$ calcd for $\mathrm{C}_{42} \mathrm{H}_{46} \mathrm{~S}_{4}[\mathrm{M}]^{+}:$: 614.3035, found: 614.3024. HRMS (MALDI-TOF-MS) $\mathrm{m} / z$ calcd for $\mathrm{C}_{42} \mathrm{H}_{46} \mathrm{~S}_{4}[\mathrm{M}]^{+}:$678.2477, found: 678.2479; mp: 141-142 ${ }^{\circ} \mathrm{C}$.

Synthesis of $2 t$

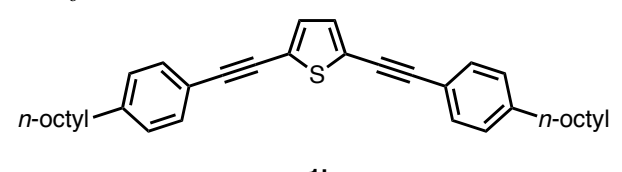

$1 \mathrm{t}$

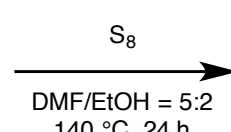

$140{ }^{\circ} \mathrm{C}, 24 \mathrm{~h}$

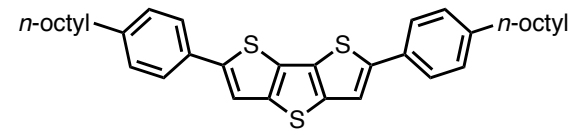

2t

To a $10-\mathrm{mL}$ Schlenk tube containing a magnetic stirring bar were added $1 \mathrm{t}$ (157 $\mathrm{mg}, 300 \mu \mathrm{mol})$ and $\mathrm{S}_{8}(154$ $\mathrm{mg}, 600 \mu \mathrm{mol})$. The tube was filled with argon, then DMF $(3.0 \mathrm{~mL})$ and $\mathrm{EtOH}(1.2 \mathrm{~mL})$ were added to the tube and the mixture was heated at $140{ }^{\circ} \mathrm{C}$ for $24 \mathrm{~h}$. The mixture was then cooled to room temperature. The crude solution was concentrated in vacuo. The residue was subjected to GPC to afford $\mathbf{2 t}$ (38.4 $\mathrm{mg}, 22 \%$ yield) as white solid.

${ }^{1} \mathrm{H}$ NMR $\left(500 \mathrm{MHz}, \mathrm{CDCl}_{3}\right) \delta 7.56(\mathrm{~d}, J=8 \mathrm{~Hz}, 4 \mathrm{H}), 7.46(\mathrm{~s}, 2 \mathrm{H}), 7.23(\mathrm{~d}, J=8 \mathrm{~Hz}, 4 \mathrm{H}), 2.63(\mathrm{t}, J=7 \mathrm{~Hz}$, $4 \mathrm{H}), 1.64$ (quint, $J=7 \mathrm{~Hz}, 4 \mathrm{H}), 1.37-1.26(\mathrm{~m}, 20 \mathrm{H}), 0.88(\mathrm{t}, J=7 \mathrm{~Hz}, 6 \mathrm{H}) ;{ }^{13} \mathrm{C} \mathrm{NMR}\left(125 \mathrm{MHz}, \mathrm{CDCl}_{3}\right) \delta$ 145.3 , 143.1 141.6, 132.1, 130.1, 129.2 , 125.7, 116.1, 35.8, 32.0, 31.5, 29.6, 29.42, 29.36, 22.8, 14.2; mp: 187-188 ${ }^{\circ} \mathrm{C}$.

The spectroscopic data were consistent with those reported in the literature. ${ }^{9}$ 


\section{1-3. Synthesis of Starting Materials}

Method A: Synthesis of $\mathbf{1}^{9}$

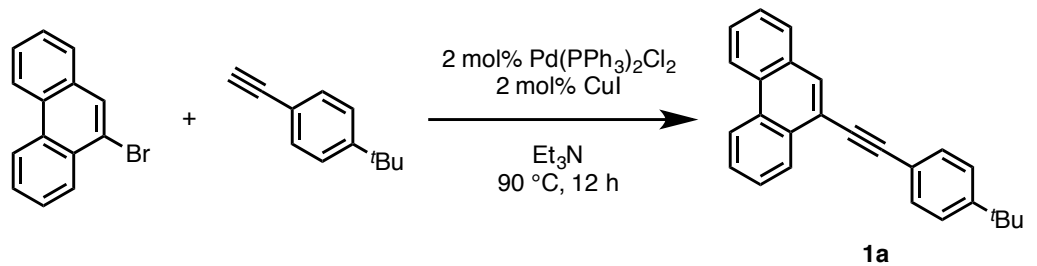

To a 500-mL Schlenk flask containing a magnetic stirring bar were added 9-bromophenanthrene (14.1 g, $55.0 \mathrm{mmol}, 1.0$ equiv), $\mathrm{Pd}\left(\mathrm{PPh}_{3}\right)_{2} \mathrm{Cl}_{2}(700 \mathrm{mg}, 1.00 \mathrm{mmol}, 2.0 \mathrm{~mol} \%$ ), and $\mathrm{CuI}(190 \mathrm{mg}, 1.00 \mathrm{mmol}, 2.0$ mol\%). The flask was filled with argon, then $\mathrm{Et}_{3} \mathrm{~N}(250 \mathrm{~mL})$ and 1-tert-butyl-4-ethynylbenzene $(8.00 \mathrm{~g}, 55.0$ mmol, 1.0 equiv) were added to the flask. The mixture was heated at $90{ }^{\circ} \mathrm{C}$ for $12 \mathrm{~h}$. The mixture was then cooled to room temperature. The crude solution was concentrated in vacuo. The residue was subjected to silica-gel chromatography $\left(\mathrm{CHCl}_{3} /\right.$ hexane $\left.=1: 20\right)$ to afford $1 \mathbf{a}(17.8 \mathrm{~g}, 97 \%$ yield $)$ as white solid.

${ }^{1} \mathrm{H}$ NMR $\left(500 \mathrm{MHz}, \mathrm{CDCl}_{3}\right) \delta 8.72-8.70(\mathrm{~m}, 1 \mathrm{H}), 8.67(\mathrm{~d}, J=8 \mathrm{~Hz}, 1 \mathrm{H}), 8.56-8.55(\mathrm{~m}, 1 \mathrm{H}), 8.08(\mathrm{~s}, 1 \mathrm{H})$, $7.88(\mathrm{~d}, J=8 \mathrm{~Hz}, 1 \mathrm{H}), 7.72-7.70(\mathrm{~m}, 2 \mathrm{H}) 7.67(\mathrm{td}, J=8,1 \mathrm{~Hz}, 1 \mathrm{H}), 7.63-7.59(\mathrm{~m}, 3 \mathrm{H}), 7.44(\mathrm{~d}, J=8 \mathrm{~Hz}$, 2H), 1.37 (s, 9H); ${ }^{13} \mathrm{C}$ NMR $\left(125 \mathrm{MHz}, \mathrm{CDCl}_{3}\right) \delta 151.8,131.6,131.5,131.3,131.2,130.2,130.1,128.6$, $128.5,127.3,127.0,126.9,125.5,122.8,122.6,120.3,119.9,94.1,87.1,34.9,31.2$; HRMS (ESI-MS) $\mathrm{m} / \mathrm{z}$ calcd for $\mathrm{C}_{26} \mathrm{H}_{22}[\mathrm{M}+\mathrm{H}]^{+}: 335.1811$, found: 335.1795 .

Method B: Palladium-free synthesis of $1 \boldsymbol{a}^{10}$

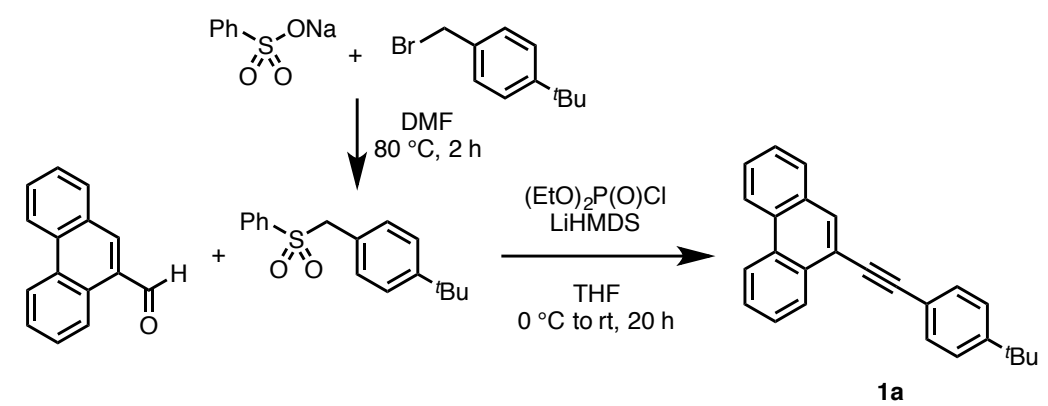

To a 100 -mL flask containing a magnetic stirring bar were added 4-tert-butylbenzyl bromide $(1.40 \mathrm{~g}, 6.16$ mmol), sodium benzenesulfinate $(1.60 \mathrm{~g}, 7.40 \mathrm{mmol})$, and DMF $(11 \mathrm{~mL})$. The mixture was heated at $80{ }^{\circ} \mathrm{C}$ for $2 \mathrm{~h}$, then poured into water and extracted with EtOAc. The crude product was purified by silica-gel chromatography $($ EtOAc/hexane $=1: 7)$ to afford 1-(tert-butyl)-4-((phenylsulfonyl)methyl)benzene $(1.75 \mathrm{~g}$, 98\%) as white solid.

To a 100-mL Shlenk flask containing a magnetic stirring bar were added 1-(tert-butyl)-4-((phenylsulfonyl)methyl)benzene (1.01 g, $3.50 \mathrm{mmol})$ and phenanthrene-9-carbaldehyde $(608 \mathrm{mg}, 2.95 \mathrm{mmol})$. The flask was filled with argon, then THF $(50 \mathrm{~mL})$ and diethyl chlorophosphate $(610$ $\mathrm{mg}, 3.54 \mathrm{mmol})$ were added. A solution of LiHMDS (1.3 M, $11.4 \mathrm{~mL}, 14.7 \mathrm{mmol})$ in THF was added dropwise at $0{ }^{\circ} \mathrm{C}$, and the mixture was starred at room temperature for $20 \mathrm{~h}$. The mixture was then cooled to room temperature and extracted with EtOAc. Silica-gel chromatography (EtOAc/hexane $=10: 1)$ of the residue afforded $1 \mathbf{a}(744 \mathrm{mg}, 76 \%)$. 
Synthesis of $1 \boldsymbol{b}^{9}$

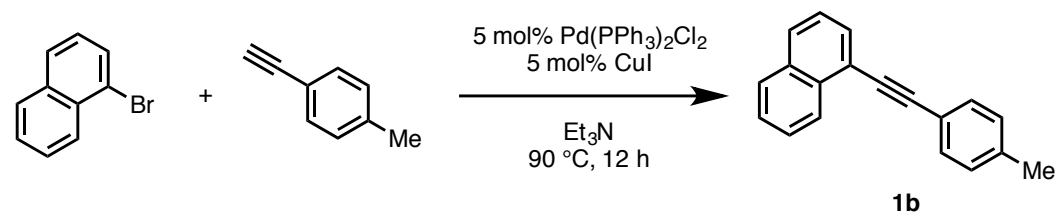

To a 50-mL Schlenk flask containing a magnetic stirring bar were added 1-bromonaphthalene (1.03 g, 5.00 mmol, 1.0 equiv), $\mathrm{Pd}\left(\mathrm{PPh}_{3}\right)_{2} \mathrm{Cl}_{2}(175 \mathrm{mg}, 250 \mu \mathrm{mol}, 5.0 \mathrm{~mol} \%)$, and $\mathrm{CuI}(50.0 \mathrm{mg}, 250 \mu \mathrm{mol}, 5.0 \mathrm{~mol} \%)$. The flask was filled with argon, then $\mathrm{Et}_{3} \mathrm{~N}(10 \mathrm{~mL})$ and 1-ethynyl-4-methylbenzene $(870 \mathrm{mg}, 7.50 \mathrm{mmol}, 1.5$ equiv) were added to the flask. The mixture was heated at $90{ }^{\circ} \mathrm{C}$ for $12 \mathrm{~h}$. The mixture was then cooled to room temperature. The crude solution was concentrated in vacuo. The residue was subjected to silica-gel chromatography $\left(\mathrm{CHCl}_{3} /\right.$ hexane $\left.=1: 20\right)$ to afford $\mathbf{1 b}(930 \mathrm{mg}, 77 \%$ yield $)$ as white solid.

${ }^{1} \mathrm{H}$ NMR $\left(500 \mathrm{MHz}, \mathrm{CDCl}_{3}\right) \delta 8.45(\mathrm{~d}, J=9 \mathrm{~Hz}, 1 \mathrm{H}), 7.86(\mathrm{~d}, J=8 \mathrm{~Hz}, 1 \mathrm{H}), 7.83(\mathrm{~d}, J=8 \mathrm{~Hz}, 1 \mathrm{H}), 7.75(\mathrm{dd}$, $J=7,1 \mathrm{~Hz}, 1 \mathrm{H}), 7.59(\mathrm{ddd}, J=9,7,1 \mathrm{~Hz}, 1 \mathrm{H}), 7.55(\mathrm{~d}, J=8 \mathrm{~Hz}, 2 \mathrm{H}), 7.53(\mathrm{ddd}, J=8,7,1 \mathrm{~Hz}, 1 \mathrm{H}), 7.46$ $(\mathrm{dd}, J=8,7 \mathrm{~Hz}, 1 \mathrm{H}), 7.21(\mathrm{~d}, J=8 \mathrm{~Hz}, 2 \mathrm{H}), 2.41(\mathrm{~s}, 3 \mathrm{H}) ;{ }^{13} \mathrm{C} \mathrm{NMR}\left(125 \mathrm{MHz}, \mathrm{CDCl}_{3}\right) \delta 138.5,133.3$, $133.2,131.5,130.2,129.2,128.5,128.3,126.7,126.4,126.3,125.3,121.1,120.3,94.5,86.9,21.5$; HRMS (ESI-MS) $\mathrm{m} / z$ calcd for $\mathrm{C}_{19} \mathrm{H}_{14}[\mathrm{M}+\mathrm{H}]^{+}: 243.1177$, found: 243.1165 .

Synthesis of $1 c^{9}$

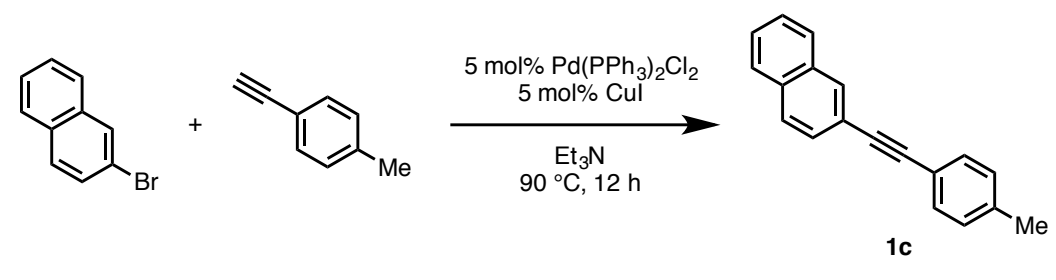

To a 50-mL Schlenk flask containing a magnetic stirring bar were added 2-bromonaphthalene (1.03 g, 5.00 mmol, 1.0 equiv), $\mathrm{Pd}\left(\mathrm{PPh}_{3}\right)_{2} \mathrm{Cl}_{2}(175 \mathrm{mg}, 250 \mu \mathrm{mol}, 5.0 \mathrm{~mol} \%)$, and $\mathrm{CuI}(50.0 \mathrm{mg}, 250 \mu \mathrm{mol}, 5.0 \mathrm{~mol} \%)$. The flask was filled with argon, then $\mathrm{Et}_{3} \mathrm{~N}(10 \mathrm{~mL})$ and 1-ethynyl-4-methylbenzene $(870 \mathrm{mg}, 7.50 \mathrm{mmol}, 1.5$ equiv) were added to the flask. The mixture was heated at $90{ }^{\circ} \mathrm{C}$ for $12 \mathrm{~h}$. The mixture was then cooled to room temperature. The crude solution was concentrated in vacuo. The residue was subjected to silica-gel chromatography $\left(\mathrm{CHCl}_{3} /\right.$ hexane $\left.=1: 20\right)$ to afford $1 \mathrm{c}(1.06 \mathrm{~g}, 88 \%$ yield $)$ as white solid.

${ }^{1} \mathrm{H}$ NMR $\left(500 \mathrm{MHz}, \mathrm{CDCl}_{3}\right) \delta 8.06(\mathrm{~s}, 1 \mathrm{H}), 7.84-7.80(\mathrm{~m}, 3 \mathrm{H}), 7.59(\mathrm{dd}, J=8,1 \mathrm{~Hz}, 1 \mathrm{H}), 7.51-7.46(\mathrm{~m}$, 4H), 7.19 (d, $J=8 \mathrm{~Hz}, 2 \mathrm{H}), 2.39$ (s, 3H); ${ }^{13} \mathrm{C} \mathrm{NMR}\left(125 \mathrm{MHz}, \mathrm{CDCl}_{3}\right) \delta$ 138.4, 133.0, 132.7, 131.5, 131.3, $129.14,129.13,128.4,127.9,127.7,126.54,126.49,120.8,120.2,89.9,89.1,21.5$; HRMS (ESI-MS) $\mathrm{m} / \mathrm{z}$ calcd for $\mathrm{C}_{19} \mathrm{H}_{14}[\mathrm{M}+\mathrm{H}]^{+}: 243.1177$, found: 243.1165 . 
Synthesis of $1 \boldsymbol{d}^{9}$

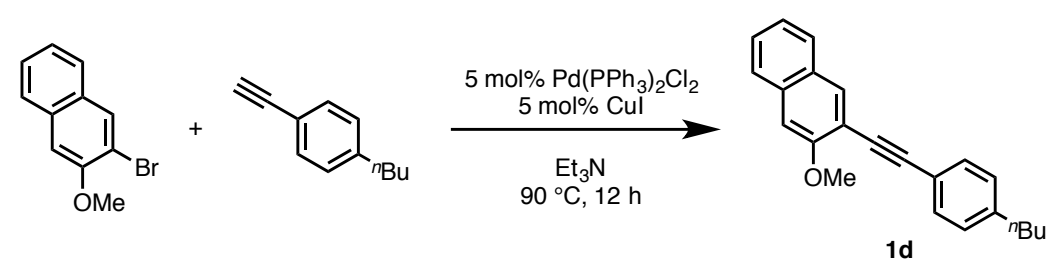

To a 50-mL Schlenk flask containing a magnetic stirring bar were added 2-bromo-3-methoxynaphthalene (200 mg, $847 \mu \mathrm{mol}, 1.0$ equiv), $\mathrm{Pd}\left(\mathrm{PPh}_{3}\right)_{2} \mathrm{Cl}_{2}(29.0 \mathrm{mg}, 40 \mu \mathrm{mmol}, 5.0 \mathrm{~mol} \%$ ), and $\mathrm{CuI}(8.4 \mathrm{mg}, 40 \mu \mathrm{mol}$, $5.0 \mathrm{~mol} \%)$. The flask was filled with argon, then $\mathrm{Et}_{3} \mathrm{~N}(10 \mathrm{~mL})$ and 1- $n$-butyl-4-ethynylbenzene (200 $\mathrm{mg}$, $1.30 \mathrm{mmol}, 1.5$ equiv) were added to the flask. The mixture was heated at $90{ }^{\circ} \mathrm{C}$ for $12 \mathrm{~h}$. The mixture was then cooled to room temperature. The residue was subject to silica-gel chromatography $\left(\mathrm{CHCl}_{3} / \mathrm{hexane}=\right.$ 1:20) to afford $\mathbf{1 d}$ (246 $\mathrm{mg}, 92 \%$ yield) as white solid.

${ }^{1} \mathrm{H}$ NMR (500 MHz, CDCl$)_{3} \delta 8.02(\mathrm{~s}, 1 \mathrm{H}), 7.73(\mathrm{t}, J=9 \mathrm{~Hz}, 2 \mathrm{H}), 7.52(\mathrm{~d}, J=8 \mathrm{~Hz}, 2 \mathrm{H}), 7.45(\mathrm{dd}, J=8,7$ $\mathrm{Hz}, 1 \mathrm{H}), 7.35(\mathrm{t}, J=8 \mathrm{~Hz}, 1 \mathrm{H}), 7.18(\mathrm{~d}, J=8 \mathrm{~Hz}, 2 \mathrm{H}), 4.02(\mathrm{~s}, 3 \mathrm{H}), 2.63(\mathrm{t}, J=8 \mathrm{~Hz}, 2 \mathrm{H}), 1.61$ (quint, $J=7$ $\mathrm{Hz}, 2 \mathrm{H}), 1.37$ (sext, $J=7 \mathrm{~Hz}, 2 \mathrm{H}), 0.94(\mathrm{t}, J=7 \mathrm{~Hz}, 3 \mathrm{H}) ;{ }^{13} \mathrm{C}$ NMR $\left(125 \mathrm{MHz}, \mathrm{CDCl}_{3}\right) \delta 156.8,143.4,134.2$, 133.6, 131.7, 128.4, 127.4, 127.0, 126.5, 124.1, 120.5, 114.4, 105.3, 93.8, 85.2, 55.9, 35.6, 33.4, 22.3, 13.9; HRMS (ESI-MS) $m / z$ calcd for $\mathrm{C}_{23} \mathrm{H}_{22} \mathrm{O}[\mathrm{M}+\mathrm{H}]^{+}: 315.1757$, found: 315.1744 .

Synthesis of $1 \boldsymbol{e}^{9}$
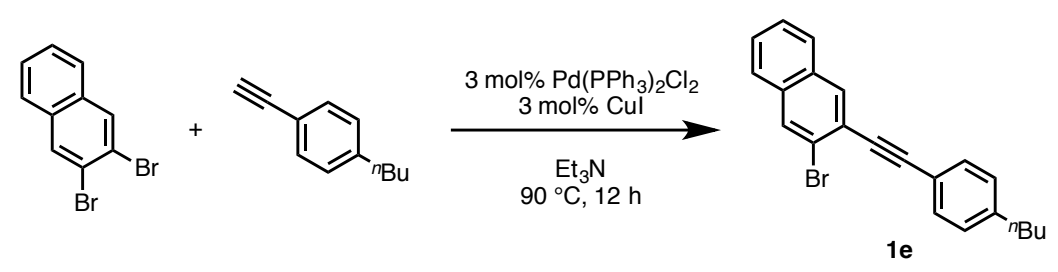

To a 100-mL Schlenk flask containing a magnetic stirring bar were added 2,3-dibromonaphthalene (906 mg, $3.15 \mathrm{mmol}, 1.0$ equiv), $\mathrm{Pd}\left(\mathrm{PPh}_{3}\right)_{2} \mathrm{Cl}_{2}(70.0 \mathrm{mg}, 100 \mu \mathrm{mol}, 3.0 \mathrm{~mol} \%)$, and $\mathrm{CuI}(20.0 \mathrm{mg}, 100 \mu \mathrm{mol}, 3.0$ $\mathrm{mol} \%)$. The flask was filled with argon, then $\mathrm{Et}_{3} \mathrm{~N}(50 \mathrm{~mL})$ and 1- $n$-butyl-4-ethynylbenzene (506 $\mathrm{mg}, 1.00$ mmol, 1.0 equiv) were added to the flask. The mixture was heated at $90{ }^{\circ} \mathrm{C}$ for $12 \mathrm{~h}$. The mixture was then cooled to room temperature. The crude solution was concentrated in vacuo. The residue was subjected to silica-gel chromatography $\left(\mathrm{CHCl}_{3} /\right.$ hexane $\left.=1: 20\right)$ to afford $1 \mathrm{e}(660 \mathrm{mg}, 58 \%$ yield $)$ as white solid.

${ }^{1} \mathrm{H}$ NMR $\left(500 \mathrm{MHz}, \mathrm{CDCl}_{3}\right) \delta 8.11(\mathrm{~s}, 1 \mathrm{H}), \delta 8.07(\mathrm{~s}, 1 \mathrm{H}), 7.78(\mathrm{dd}, J=6,3 \mathrm{~Hz}, 1 \mathrm{H}), 7.73(\mathrm{dd}, J=6,3 \mathrm{~Hz}$, $1 \mathrm{H}), 7.53(\mathrm{~d}, J=8 \mathrm{~Hz}, 2 \mathrm{H}), 7.50(\mathrm{dd}, J=6,3 \mathrm{~Hz}, 2 \mathrm{H}), 7.19(\mathrm{~d}, J=8 \mathrm{~Hz}, 2 \mathrm{H}), 2.65(\mathrm{t}, J=8 \mathrm{~Hz}, 2 \mathrm{H}), 1.62$ (quint, $J=7 \mathrm{~Hz}, 2 \mathrm{H}), 1.38$ (sext, $J=7 \mathrm{~Hz}, 2 \mathrm{H}), 0.96(\mathrm{t}, J=7 \mathrm{~Hz}, 3 \mathrm{H}) ;{ }^{13} \mathrm{C}$ NMR $\left(125 \mathrm{MHz}, \mathrm{CDCl}_{3}\right) \delta 143.9$, 133.5, 132.8, 131.8, 131.6, 130.9, 128.5, 127.6, 127.4, 126.81, 126.78, 122.9, 122.1, 120.1, 94.0, 87.8, 35.6, 33.4, 22.3, 13.9; HRMS (ESI-MS) $m / z$ calcd for $\mathrm{C}_{22} \mathrm{H}_{19} \mathrm{Br}[\mathrm{M}+\mathrm{H}]^{+}: 363.0755$, found: 363.0739 . 
Synthesis of $\mathbf{1 f}^{9}$
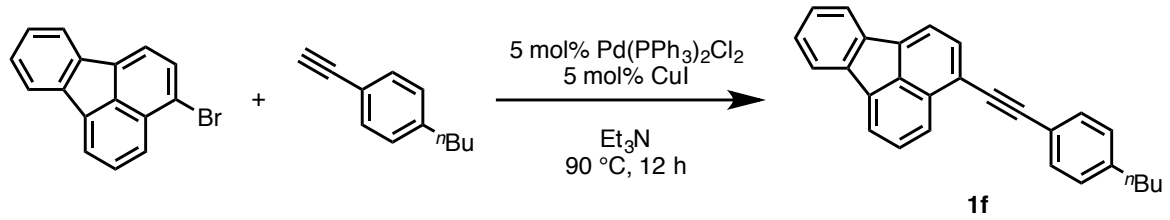

To a 50-mL Schlenk flask containing a magnetic stirring bar were added 3-bromofluoranthene (281 mg, 1.00 mmol, 1.0 equiv), $\mathrm{Pd}\left(\mathrm{PPh}_{3}\right)_{2} \mathrm{Cl}_{2}(35.0 \mathrm{mg}, 50.0 \mu \mathrm{mol}, 5.0 \mathrm{~mol} \%)$, and $\mathrm{CuI}(10.0 \mathrm{mg}, 50.0 \mu \mathrm{mol}, 5.0 \mathrm{~mol} \%)$. The flask was filled with argon, then $\mathrm{Et}_{3} \mathrm{~N}(10 \mathrm{~mL})$ and 1- $n$-butyl-4-ethynylbenzene $(237 \mathrm{mg}, 1.50 \mathrm{mmol}, 1.5$ equiv) were added to the flask. The mixture was heated at $90{ }^{\circ} \mathrm{C}$ for $12 \mathrm{~h}$. The mixture was then cooled to room temperature. The crude solution was concentrated in vacuo. The residue was subjected to silica-gel chromatography $\left(\mathrm{CHCl}_{3} /\right.$ hexane $\left.=1: 20\right)$ to afford $\mathbf{1 f}(293 \mathrm{mg}, 82 \%$ yield $)$ as green solid.

${ }^{1} \mathrm{H}$ NMR $\left(500 \mathrm{MHz}, \mathrm{CDCl}_{3}, 25^{\circ} \mathrm{C}\right) \delta 8.22(\mathrm{~d}, J=8 \mathrm{~Hz}, 1 \mathrm{H}), 7.94(\mathrm{~d}, J=7 \mathrm{~Hz}, 1 \mathrm{H}), 7.90-7.87(\mathrm{~m}, 3 \mathrm{H}), 7.84$ $(\mathrm{d}, J=7 \mathrm{~Hz}, 1 \mathrm{H}), 7.69(\mathrm{dd}, J=8,7 \mathrm{~Hz}, 1 \mathrm{H}), 7.58(\mathrm{~d}, J=8 \mathrm{~Hz}, 2 \mathrm{H}), 7.38(\mathrm{dd}, J=6,3 \mathrm{~Hz}, 2 \mathrm{H}), 7.23(\mathrm{~d}, J=8$ $\mathrm{Hz}, 2 \mathrm{H}$ ), 2.67 (t, $J=8 \mathrm{~Hz}, 2 \mathrm{H}), 1.64$ (quint, $J=7 \mathrm{~Hz}, 2 \mathrm{H}), 1.40$ (sext, $J=7 \mathrm{~Hz}, 2 \mathrm{H}), 0.96$ (t, $J=7 \mathrm{~Hz}, 3 \mathrm{H}$ ); ${ }^{13} \mathrm{C}$ NMR $\left(125 \mathrm{MHz}, \mathrm{CDCl}_{3}\right) \delta 143.7,139.7,139.0,137.2,137.1,132.3,132.0,131.6,130.4,128.6,128.5$, $127.8,127.7,125.4,121.7,121.6,120.9$, 120.6, 120.4, 119.7, 95.3, 86.8, 35.7, 33.4, 22.3, 13.9; HRMS (ESI-MS) $m / z$ calcd for $\mathrm{C}_{28} \mathrm{H}_{22}[\mathrm{M}+\mathrm{H}]^{+}: 359.1799$, found: 359.1750 .

Synthesis of $1 \mathrm{~g}^{9}$
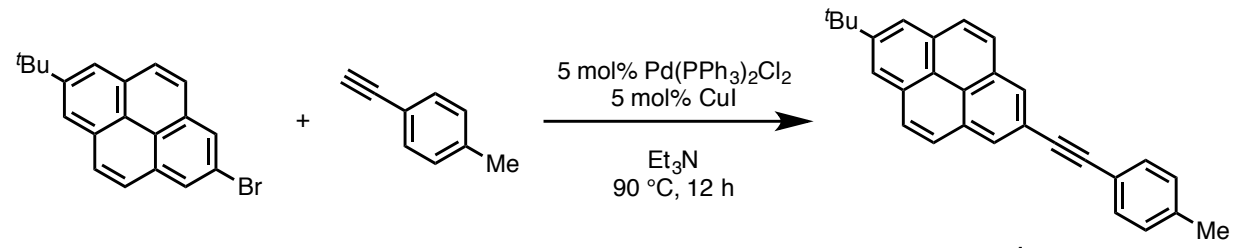

$1 \mathrm{~g}$

To a 50-mL Schlenk flask containing a magnetic stirring bar were added 2-bromo-7-(tert-butyl)pyrene (281 $\mathrm{mg}, 1.00 \mathrm{mmol}, 1.0$ equiv), $\mathrm{Pd}\left(\mathrm{PPh}_{3}\right)_{2} \mathrm{Cl}_{2}(35.0 \mathrm{mg}, 50.0 \mu \mathrm{mol}, 5 \mathrm{~mol} \%)$, and $\mathrm{CuI}(10.0 \mathrm{mg}, 50.0 \mu \mathrm{mol}, 5$ mol\%). The flask was filled with argon, then $\mathrm{Et}_{3} \mathrm{~N}(10 \mathrm{~mL})$ and 1-ethynyl-4-methylbenzene $(237 \mathrm{mg}, 1.50$ mmol, 1.5 equiv) were added to the flask. The mixture was heated at $90{ }^{\circ} \mathrm{C}$ for $12 \mathrm{~h}$. The mixture was then cooled to room temperature. The crude solution was concentrated in vacuo. The residue was subjected to silica-gel chromatography $\left(\mathrm{CHCl}_{3} /\right.$ hexane $\left.=1: 20\right)$ to afford $\mathbf{1 g}(358 \mathrm{mg}, 96 \%$ yield $)$ as white solid.

${ }^{1} \mathrm{H}$ NMR $\left(500 \mathrm{MHz}, \mathrm{CDCl}_{3}\right) \delta 8.30(\mathrm{~s}, 2 \mathrm{H}), 8.22(\mathrm{~s}, 2 \mathrm{H}), 8.06(\mathrm{~d}, J=9 \mathrm{~Hz}, 2 \mathrm{H}), 8.01(\mathrm{~d}, J=9 \mathrm{~Hz}, 2 \mathrm{H}), 7.54$ $(\mathrm{d}, J=8 \mathrm{~Hz}, 2 \mathrm{H}), 7.21(\mathrm{~d}, J=8 \mathrm{~Hz}, 2 \mathrm{H}), 2.41(\mathrm{~s}, 3 \mathrm{H}), 1.59(\mathrm{~s}, 9 \mathrm{H}) ;{ }^{13} \mathrm{C}$ NMR $\left(125 \mathrm{MHz}, \mathrm{CDCl}_{3}\right) \delta 149.5$, 138.5, 132.4, 131.6, 131.1, 130.9, 129.2, 128.2, 127.5, 126.8, 124.1, 122.6, 120.5, 120.3, 89.8, 89.5, 35.3, $31.9,21.5$; HRMS (ESI-MS) $\mathrm{m} / \mathrm{z}$ calcd for $\mathrm{C}_{29} \mathrm{H}_{24}[\mathrm{M}+\mathrm{H}]^{+}: 373.1956$, found: 373.1945 . 
Synthesis of $1 h^{9}$

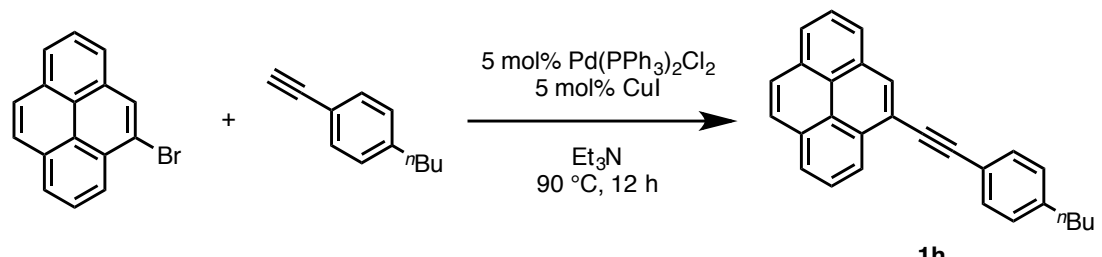

$1 \mathrm{~h}$

To a 50-mL Schlenk flask containing a magnetic stirring bar were added 4-bromopyrene (281 mg, 1.00 mmol, 1.0 equiv), $\mathrm{Pd}\left(\mathrm{PPh}_{3}\right)_{2} \mathrm{Cl}_{2}(35.0 \mathrm{mg}, 50.0 \mu \mathrm{mol}, 5.0 \mathrm{~mol} \%)$, and $\mathrm{CuI}(10 \mathrm{mg}, 50.0 \mu \mathrm{mol}, 5.0 \mathrm{~mol} \%)$. The flask was filled with argon, then $\mathrm{Et}_{3} \mathrm{~N}(10 \mathrm{~mL})$ and 1- $n$-butyl-4-ethynylbenzene $(237 \mathrm{mg}, 1.50 \mathrm{mmol}, 1.5$ equiv) were added to the flask. The mixture was heated at $90{ }^{\circ} \mathrm{C}$ for $12 \mathrm{~h}$. The mixture was then cooled to room temperature. The crude solution was concentrated in vacuo. The residue was subjected to silica-gel chromatography $\left(\mathrm{CHCl}_{3} /\right.$ hexane $\left.=1: 20\right)$ to afford $\mathbf{1 h}(322 \mathrm{mg}, 90 \%$ yield $)$ as green solid.

${ }^{1} \mathrm{H}$ NMR $\left(500 \mathrm{MHz}, \mathrm{CDCl}_{3}\right) \delta 8.78(\mathrm{~d}, J=7 \mathrm{~Hz}, 1 \mathrm{H}), 8.40(\mathrm{~s}, 1 \mathrm{H}), 8.24(\mathrm{~d}, J=7 \mathrm{~Hz}, 1 \mathrm{H}), 8.19(\mathrm{t}, J=8 \mathrm{~Hz}$, $2 \mathrm{H}), 8.12-8.07(\mathrm{~m}, 3 \mathrm{H}), 8.02(\mathrm{t}, J=8 \mathrm{~Hz}, 1 \mathrm{H}), 7.65(\mathrm{~d}, J=8 \mathrm{~Hz}, 2 \mathrm{H}), 7.26(\mathrm{~d}, J=8 \mathrm{~Hz}, 2 \mathrm{H}), 2.67(\mathrm{t}, J=8$ $\mathrm{Hz}, 2 \mathrm{H}), 1.64$ (quint, $J=7 \mathrm{~Hz}, 2 \mathrm{H}), 1.40$ (sext, $J=7 \mathrm{~Hz}, 2 \mathrm{H}), 0.96(\mathrm{t}, J=7 \mathrm{~Hz}, 3 \mathrm{H}) ;{ }^{13} \mathrm{C} \mathrm{NMR}(125 \mathrm{MHz}$, $\left.\mathrm{CDCl}_{3}\right) \delta 143.7,131.9,131.7,131.2,131.0,130.4,128.6,127.6,127.2,126.1,125.7,125.6,125.1,124.5$, $124.2,123.9,120.6,120.5,94.4,87.2,35.7,33.4,22.4,14.0$; HRMS (ESI-MS) $m / z$ calcd for $\mathrm{C}_{28} \mathrm{H}_{22}[\mathrm{M}+\mathrm{H}]^{+}$: 359.1799 , found: 359.1786 .

Synthesis of $\mathbf{1 i}^{9}$
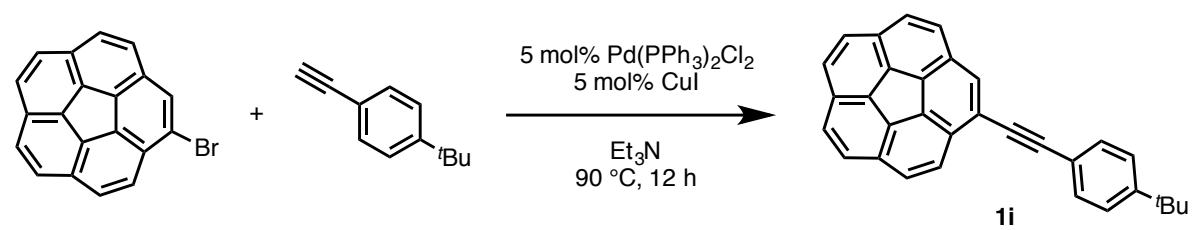

To a 50-mL Schlenk flask containing a magnetic stirring bar were added bromocorannulene (329 mg, 1 mmol, 1.0 equiv), $\mathrm{Pd}\left(\mathrm{PPh}_{3}\right)_{2} \mathrm{Cl}_{2}$ (35.0 mg, $50.0 \mu \mathrm{mol}, 5.0 \mathrm{~mol} \%$ ), and $\mathrm{CuI}$ (10.0 mg, $50.0 \mu \mathrm{mol}, 5.0 \mathrm{~mol} \%$ ). The flask was filled with argon, then $\mathrm{Et}_{3} \mathrm{~N}(10 \mathrm{~mL})$ and 1-tert-butyl-4-ethynylbenzene $(237 \mathrm{mg}, 1.50 \mathrm{mmol}$, 1.5 equiv) were added to the flask. The mixture was heated at $90{ }^{\circ} \mathrm{C}$ for $12 \mathrm{~h}$. The mixture was then cooled to room temperature. The crude solution was concentrated in vacuo. The residue was subjected to silica-gel chromatography $\left(\mathrm{CHCl}_{3} /\right.$ hexane $\left.=1: 20\right)$ to afford $\mathbf{1 i}(358 \mathrm{mg}, 88 \%$ yield $)$ as white solid.

${ }^{1} \mathrm{H}$ NMR $\left(500 \mathrm{MHz}, \mathrm{CDCl}_{3}\right) \delta 8.13(\mathrm{~d}, J=9 \mathrm{~Hz}, 1 \mathrm{H}), 8.05(\mathrm{~s}, 1 \mathrm{H}), 7.88(\mathrm{~d}, J=9 \mathrm{~Hz}, 1 \mathrm{H}), 7.83-7.79(\mathrm{~m}, 5 \mathrm{H})$, $7.77(\mathrm{~d}, J=9 \mathrm{~Hz}, 1 \mathrm{H}), 7.61(\mathrm{~d}, J=8 \mathrm{~Hz}, 2 \mathrm{H}), 7.44(\mathrm{~d}, J=8 \mathrm{~Hz}, 2 \mathrm{H}), 1.37(\mathrm{~s}, 9 \mathrm{H}) ;{ }^{13} \mathrm{C} \mathrm{NMR}(125 \mathrm{MHz}$, $\left.\mathrm{CDCl}_{3}\right) \delta 151.8,135.9,135.5,135.0,132.1,132.0,131.9,131.5,131.0,130.92,130.87,130.83,130.76$, $130.3,128.5,128.4,127.4,127.3,127.2$, 127.0, 126.5, 126.0, 125.5, 121.6, 120.3, 93.4, 87.2, 34.8, 31.2; HRMS (ESI-MS) $m / z$ calcd for $\mathrm{C}_{32} \mathrm{H}_{22}[\mathrm{M}+\mathrm{H}]^{+}: 407.1802$, found: 407.1787 . 
Synthesis of $\mathbf{1 j}^{9}$

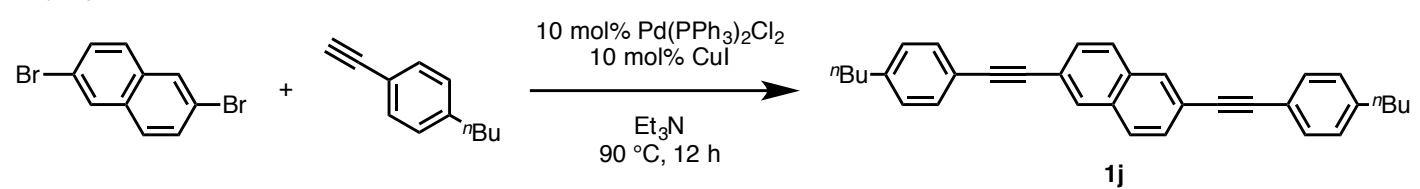

To a 50-mL Schlenk flask containing a magnetic stirring bar were added 2,6-dibromonaphthalene (143 mg, $500 \mu \mathrm{mol}, 1.0$ equiv), $\mathrm{Pd}\left(\mathrm{PPh}_{3}\right)_{2} \mathrm{Cl}_{2}(35.0 \mathrm{mg}, 50.0 \mu \mathrm{mol}, 10 \mathrm{~mol} \%)$, and $\mathrm{CuI}(10.0 \mathrm{mg}, 50.0 \mu \mathrm{mol}, 10 \mathrm{~mol} \%)$. The flask was filled with argon, then $\mathrm{Et}_{3} \mathrm{~N}(10 \mathrm{~mL})$ and 1- $n$-butyl-4-ethynylbenzene $(237 \mathrm{mg}, 1.50 \mathrm{mmol}, 3.0$ equiv) were added to the flask. The mixture was heated at $90{ }^{\circ} \mathrm{C}$ for $12 \mathrm{~h}$. The mixture was then cooled to room temperature. The crude solution was concentrated in vacuo. The residue was subjected to silica-gel chromatography $\left(\mathrm{CHCl}_{3} /\right.$ hexane $\left.=1: 10\right)$ to afford $\mathbf{1} \mathbf{j}(180 \mathrm{mg}, 81 \%$ yield $)$ as white solid.

${ }^{1} \mathrm{H}$ NMR $\left(500 \mathrm{MHz}, \mathrm{CDCl}_{3}\right) \delta 8.00(\mathrm{~s}, 2 \mathrm{H}), 7.77(\mathrm{~d}, J=9 \mathrm{~Hz}, 2 \mathrm{H}), 7.58(\mathrm{~d}, J=9 \mathrm{~Hz}, 2 \mathrm{H}), 7.49(\mathrm{~d}, J=8 \mathrm{~Hz}$, 4H), $7.19(\mathrm{~d}, J=8 \mathrm{~Hz}, 4 \mathrm{H}), 2.64(\mathrm{t}, J=8 \mathrm{~Hz}, 4 \mathrm{H}), 1.62$ (quint, $J=7 \mathrm{~Hz}, 4 \mathrm{H}), 1.38$ (sext, $J=7 \mathrm{~Hz}, 4 \mathrm{H}$ ), 0.95 $(\mathrm{t}, J=7 \mathrm{~Hz}, 6 \mathrm{H}) ;{ }^{13} \mathrm{C}$ NMR $\left(125 \mathrm{MHz}, \mathrm{CDCl}_{3}\right) \delta 143.6,132.3,131.6,131.0,129.1,128.5,127.7,121.5$, 120.3 , 90.7, 89.0, 35.6, 33.4, 22.3, 13.9; HRMS (ESI-MS) $\mathrm{m} / z$ calcd for $\mathrm{C}_{34} \mathrm{H}_{32}[\mathrm{M}+\mathrm{H}]^{+}:$441.2586, found: 441.2570 .

Synthesis of $1 \boldsymbol{k}^{9}$
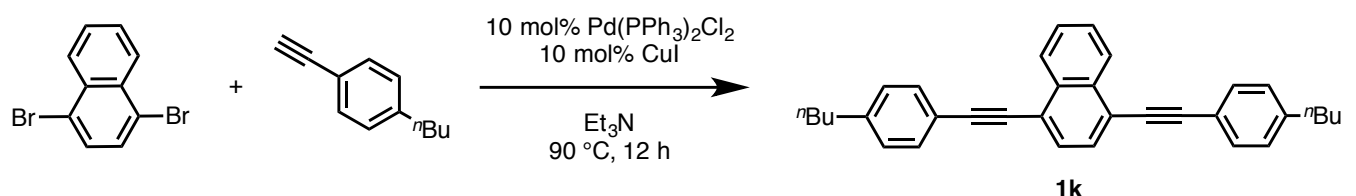

To a 50-mL Schlenk flask containing a magnetic stirring bar were added 2,4-dibromonaphthalene (143 mg, $500 \mu \mathrm{mol}, 1.0$ equiv), $\mathrm{Pd}\left(\mathrm{PPh}_{3}\right)_{2} \mathrm{Cl}_{2}(35.0 \mathrm{mg}, 50.0 \mu \mathrm{mol}, 10 \mathrm{~mol} \%)$, and $\mathrm{CuI}(10.0 \mathrm{mg}, 50.0 \mu \mathrm{mol}, 10 \mathrm{~mol} \%)$. The flask was filled with argon, then $\mathrm{Et}_{3} \mathrm{~N}(10 \mathrm{~mL})$ and 1- $n$-butyl-4-ethynylbenzene $(237 \mathrm{mg}, 1.50 \mathrm{mmol}, 3.0$ equiv) were added to the flask. The mixture was heated at $90{ }^{\circ} \mathrm{C}$ for $12 \mathrm{~h}$. The mixture was then cooled to room temperature. The crude solution was concentrated in vacuo. The residue was subjected to silica-gel chromatography $\left(\mathrm{CHCl}_{3} /\right.$ hexane $\left.=1: 10\right)$ to afford $1 \mathbf{k}(224 \mathrm{mg}, 99 \%$ yield $)$ as white solid.

${ }^{1} \mathrm{H}$ NMR $\left(500 \mathrm{MHz}, \mathrm{CDCl}_{3}\right) \delta 8.47(\mathrm{dd}, J=6,3 \mathrm{~Hz}, 2 \mathrm{H}), 7.72(\mathrm{~s}, 2 \mathrm{H}), 7.64(\mathrm{dd}, J=6,3 \mathrm{~Hz}, 2 \mathrm{H}), 7.57(\mathrm{~d}, J$ $=8 \mathrm{~Hz}, 4 \mathrm{H}), 7.22(\mathrm{~d}, J=8 \mathrm{~Hz}, 4 \mathrm{H}), 2.66(\mathrm{t}, J=8 \mathrm{~Hz}, 4 \mathrm{H}), 1.64$ (quint, $J=7 \mathrm{~Hz}, 4 \mathrm{H}), 1.39$ (sext, $J=7 \mathrm{~Hz}$, $4 \mathrm{H}), 0.96(\mathrm{t}, J=7 \mathrm{~Hz}, 6 \mathrm{H}) ;{ }^{13} \mathrm{C}$ NMR $\left(125 \mathrm{MHz}, \mathrm{CDCl}_{3}\right) \delta 143.8,133.1,131.6,129.6,128.6,127.1,126.7$, $121.5,120.3,96.2,86.9,35.7,33.4,22.3,13.9$; HRMS (ESI-MS) $m / z$ calcd for $\mathrm{C}_{34} \mathrm{H}_{32}[\mathrm{M}+\mathrm{H}]^{+}: 441.2586$, found: 441.2569 . 
Synthesis of $1 \mathbf{l}^{9}$
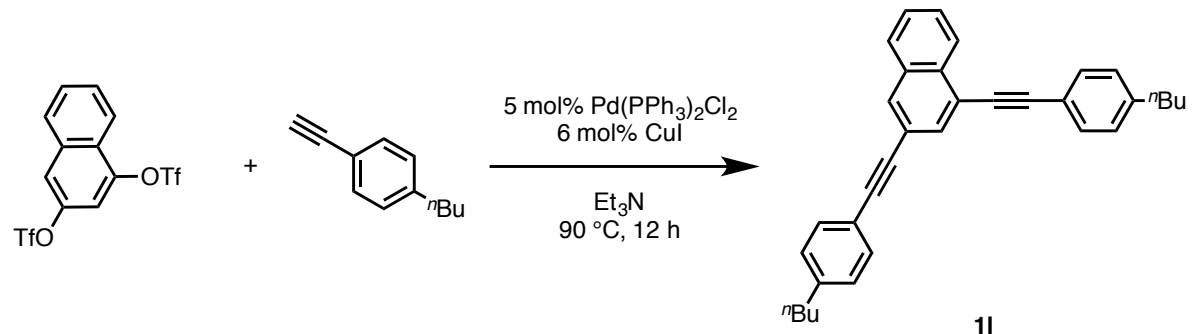

To a 50-mL Schlenk flask containing a magnetic stirring bar were added naphthalene-1,3-diyl bis(trifluoromethanesulfonate) (242 mg, $570 \mu \mathrm{mol}, 1.0$ equiv), $\mathrm{Pd}\left(\mathrm{PPh}_{3}\right)_{2} \mathrm{Cl}_{2}(20.0 \mathrm{mg}, 28.5 \mu \mathrm{mol}, 5.0 \mathrm{~mol} \%$ ), and $\mathrm{CuI}(6.0 \mathrm{mg}, 31.5 \mu \mathrm{mol}, 6.0 \mathrm{~mol} \%)$. The flask was filled with argon, then $\mathrm{Et}_{3} \mathrm{~N}(10 \mathrm{~mL})$ and 1- $n$-butyl-4-ethynylbenzene ( $270 \mathrm{mg}, 1.70 \mathrm{mmol}, 3.0$ equiv) were added to the flask. The mixture was heated at $80{ }^{\circ} \mathrm{C}$ for $12 \mathrm{~h}$. The mixture was then cooled to room temperature. The residue was subjected to silica-gel chromatography $\left(\mathrm{CHCl}_{3} /\right.$ hexane $\left.=1: 10\right)$ to afford 11 ( $241 \mathrm{mg}, 96 \%$ yield $)$ as white solid.

${ }^{1} \mathrm{H}$ NMR $\left(500 \mathrm{MHz}, \mathrm{CDCl}_{3}\right) \delta 8.40(\mathrm{~d}, J=8 \mathrm{~Hz}, 1 \mathrm{H}), 8.01(\mathrm{~s}, 1 \mathrm{H}), 7.87(\mathrm{~d}, J=1 \mathrm{~Hz}, 1 \mathrm{H}), 7.83(\mathrm{~d}, J=8 \mathrm{~Hz}$, $1 \mathrm{H}), 7.60-7.52(\mathrm{~m}, 4 \mathrm{H}), 7.49(\mathrm{~d}, J=8 \mathrm{~Hz}, 2 \mathrm{H}), 7.22(\mathrm{~d}, J=8 \mathrm{~Hz}, 2 \mathrm{H}), 7.19(\mathrm{~d}, J=8 \mathrm{~Hz}, 2 \mathrm{H}), 2.66(\mathrm{t}, J=8$ $\mathrm{Hz}, 2 \mathrm{H}$ ), $2.65(\mathrm{t}, J=8 \mathrm{~Hz}, 2 \mathrm{H}$ ), 1.64 (quint, $J=7 \mathrm{~Hz}, 4 \mathrm{H}$ ), 1.63 (quint, $J=7 \mathrm{~Hz}, 4 \mathrm{H}$ ), 1.39 (sext, $J=7 \mathrm{~Hz}$, $4 \mathrm{H}), 1.38$ (sext, $J=7 \mathrm{~Hz}, 4 \mathrm{H}), 0.96(\mathrm{t}, J=7 \mathrm{~Hz}, 3 \mathrm{H}), 0.95(\mathrm{t}, J=7 \mathrm{~Hz}, 3 \mathrm{H}) ;{ }^{13} \mathrm{C} \mathrm{NMR}\left(125 \mathrm{MHz}, \mathrm{CDCl}_{3}\right) \delta$ 143.8, 143.6, 132.6, 131.61, 131.59, 131.5, 128.6, 128.5, 128.1, 127.3, 127.0, 126.2, 121.6, 120.6, 94.9, 90.3, 88.4, 88.1, 35.6, 33.41, 33.38, 31.6, 22.6, 22.3, 14.1, 13.9; HRMS (ESI-MS) $\mathrm{m} / \mathrm{z}$ calcd for $\mathrm{C}_{38} \mathrm{H}_{40}[\mathrm{M}+\mathrm{H}]^{+}$: 441.2569 , found: 441.2586 .

Synthesis of $\mathbf{1} \mathbf{m}^{9}$
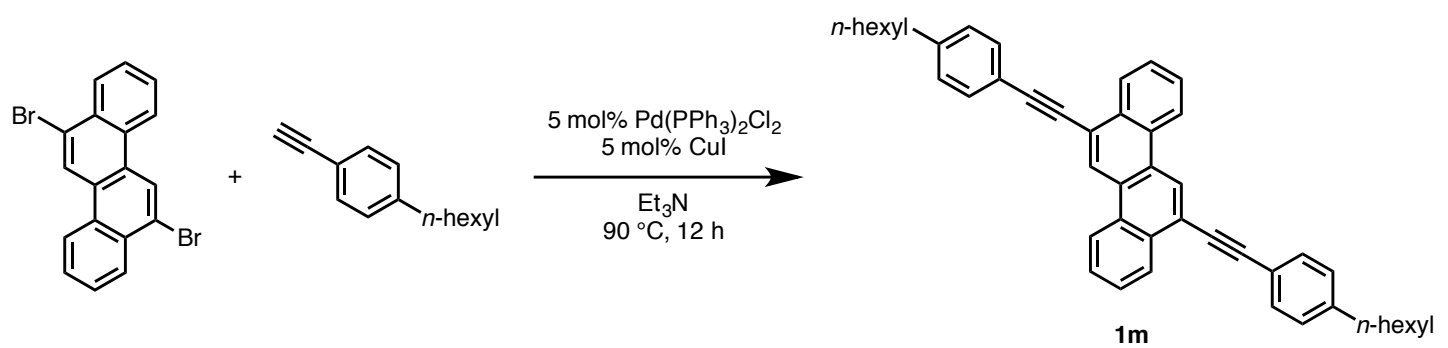

To a 50-mL Schlenk flask containing a magnetic stirring bar were added 6,12-dibromochrysene (772 $\mathrm{mg}$, $2.00 \mathrm{mmol}, 1.0$ equiv), $\mathrm{Pd}\left(\mathrm{PPh}_{3}\right)_{2} \mathrm{Cl}_{2}(70.0 \mathrm{mg}, 100.0 \mu \mathrm{mol}, 5 \mathrm{~mol} \%)$, and $\mathrm{CuI}(20.0 \mathrm{mg}, 100.0 \mu \mathrm{mol}, 5$ mol\%). The flask was filled with argon, then $\mathrm{Et}_{3} \mathrm{~N}(10 \mathrm{~mL})$ and 1-ethynyl-4- $n$-hexylbenzene $(948 \mathrm{mg}, 5.00$ mmol, 2.5 equiv) were added to the flask. The mixture was heated at $90{ }^{\circ} \mathrm{C}$ for $12 \mathrm{~h}$. The mixture was then cooled to room temperature. The crude solution was concentrated in vacuo. The residue was subjected to silica-gel chromatography $\left(\mathrm{CHCl}_{3} /\right.$ hexane $\left.=1: 10\right)$ to afford $1 \mathrm{~m}(583 \mathrm{mg}, 49 \%$ yield $)$ as yellow solid. ${ }^{1} \mathrm{H}$ NMR $\left(500 \mathrm{MHz}, \mathrm{CDCl}_{3}\right) \delta 8.99(\mathrm{~s}, 2 \mathrm{H}), 8.81(\mathrm{~d}, J=7.5 \mathrm{~Hz}, 2 \mathrm{H}), 8.62(\mathrm{dd}, J=7,2 \mathrm{~Hz}, 2 \mathrm{H}), 7.79-7.73$ (m, 4H), $7.64(\mathrm{~d}, J=8 \mathrm{~Hz}, 4 \mathrm{H}), 7.26(\mathrm{~d}, J=8 \mathrm{~Hz}, 4 \mathrm{H}), 2.68(\mathrm{t}, J=7 \mathrm{~Hz}, 4 \mathrm{H}), 1.67$ (quint, $J=7 \mathrm{~Hz}, 4 \mathrm{H}$ ), $1.41-1.31(\mathrm{~m}, 12 \mathrm{H}), 0.91(\mathrm{t}, J=7 \mathrm{~Hz}, 6 \mathrm{H}) ;{ }^{13} \mathrm{C} \mathrm{NMR}\left(125 \mathrm{MHz}, \mathrm{CDCl}_{3}\right) \delta 143.8,131.7,131.5,129.9,128.6$, 127.6, 127.3, 127.1 , 127.07, 126.95, 125.7, 123.3, 121.0, 120.4, 95.2, 87.6, 36.0, 31.7, 31.2, 29.0, 22.6, 14.1; HRMS (ESI-MS) $\mathrm{m} / z$ calcd for $\mathrm{C}_{46} \mathrm{H}_{44}[\mathrm{M}+\mathrm{H}]^{+}:$597.3517, found: 597.3506 . 
Synthesis of $\mathbf{1 n}^{11}$
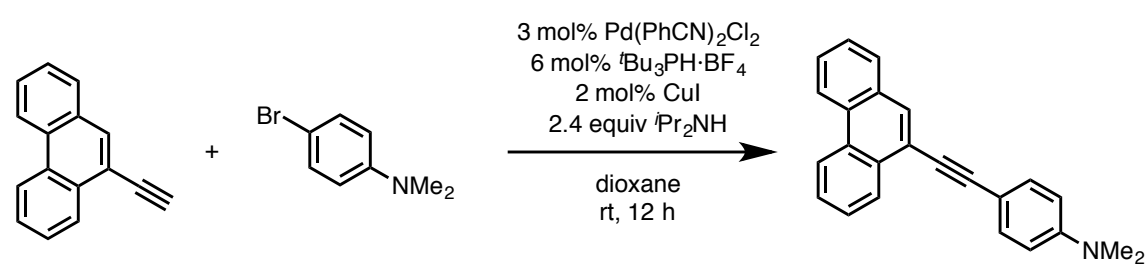

1n

To a $10-\mathrm{mL}$ Schlenk tube containing a magnetic stirring bar were added 9-ethynylphenanthrene (303 $\mathrm{mg}$, $1.50 \mathrm{mmol}, 1.0$ equiv), 4-bromo- $N, N$-dimethylaniline (300 mg, $1.50 \mathrm{mmol}, 1.0$ equiv), $\mathrm{Pd}(\mathrm{PhCN})_{2} \mathrm{Cl}_{2}(17.0$ $\mathrm{mg}, 45.0 \mu \mathrm{mol}, 3.0 \mathrm{~mol} \%),{ }^{t} \mathrm{Bu}_{3} \mathrm{PH} \mathrm{BF}_{4}(26.0 \mathrm{mg}, 90.0 \mu \mathrm{mol}, 6.0 \mathrm{~mol} \%)$, and $\mathrm{CuI}(5.7 \mathrm{mg}, 30.0 \mu \mathrm{mol}, 2$ mol\%). The tube was filled with argon, then 1,4-dioxane $(1.5 \mathrm{~mL})$ and $\mathrm{HN}^{i} \operatorname{Pr}_{2}(364 \mathrm{mg}, 3.60 \mu \mathrm{mol}, 2.4$ equiv) were added to the flask. Then the mixture was stirred at room temperature for $12 \mathrm{~h}$. The crude solution was concentrated in vacuo. The residue was subjected to silica-gel chromatography $\left(\mathrm{CHCl}_{3} /\right.$ hexane $=1: 20)$ to afford $1 \mathbf{n}$ (473 $\mathrm{mg}, 98 \%$ yield) as white solid.

${ }^{1} \mathrm{H} \mathrm{NMR}\left(500 \mathrm{MHz}, \mathrm{CDCl}_{3}\right) \delta 8.70(\mathrm{dd}, J=6,3 \mathrm{~Hz}, 1 \mathrm{H}), 8.66(\mathrm{~d}, J=8 \mathrm{~Hz}, 1 \mathrm{H}), 8.58(\mathrm{dd}, J=6,3 \mathrm{~Hz}, 1 \mathrm{H})$, $8.04(\mathrm{~s}, 1 \mathrm{H}), 7.86(\mathrm{~d}, J=8 \mathrm{~Hz}, 1 \mathrm{H}), 7.70(\mathrm{dd}, J=6,3 \mathrm{~Hz}, 2 \mathrm{H}), 7.64(\mathrm{t}, J=8 \mathrm{~Hz}, 1 \mathrm{H}), 7.60(\mathrm{~d}, J=8 \mathrm{~Hz}, 1 \mathrm{H})$, $7.56(\mathrm{~d}, J=8 \mathrm{~Hz}, 2 \mathrm{H}), 6.73(\mathrm{~d}, J=8 \mathrm{~Hz}, 2 \mathrm{H}), 3.03(\mathrm{~s}, 6 \mathrm{H}) ;{ }^{13} \mathrm{C}$ NMR $\left(125 \mathrm{MHz}, \mathrm{CDCl}_{3}\right) \delta 150.2,132.8$, $131.5,131.3,130.7,130.1,129.9,128.3,127.1,126.94,126.88,126.8,122.7,122.5,120.5,111.8,110.0$, 95.4, 85.7, 40.1; HRMS (MALDI-TOF-MS) $\mathrm{m} / \mathrm{z}$ calcd for $\mathrm{C}_{24} \mathrm{H}_{19} \mathrm{~N}[\mathrm{M}]^{+}: 321.1512$, found: 321.1491 .

Synthesis of $\mathbf{1 o}^{12}$
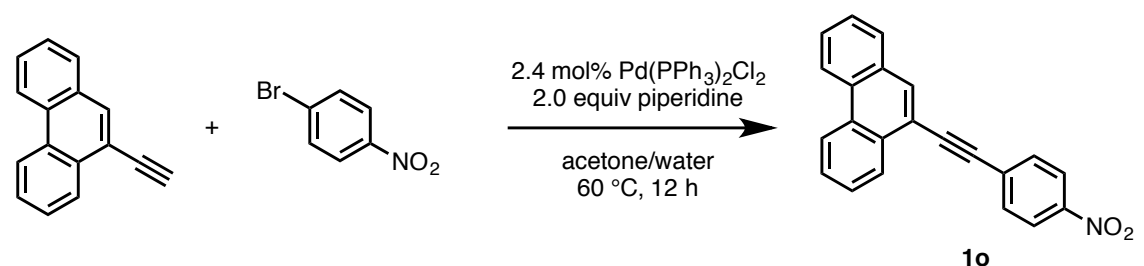

To a 50-mL Schlenk flask containing a magnetic stirring bar were added 9-ethynylphenanthrene (202 mg, $1.00 \mathrm{mmol}, 1.0$ equiv), 1-bromo-4-nitrobenzene (200 mg, $1.00 \mathrm{mmol}, 1.0$ equiv), and $\mathrm{Pd}\left(\mathrm{PPh}_{3}\right)_{2} \mathrm{Cl}_{2}(17.0 \mathrm{mg}$, $24.0 \mu \mathrm{mol}, 2.4 \mathrm{~mol} \%)$. The flask was filled with argon, then water $(3.0 \mathrm{~mL})$, acetone $(3.0 \mathrm{~mL})$, and piperidine ( $170 \mathrm{mg}, 2.0$ equiv) were added to the flask. Then the mixture was stirred at $60{ }^{\circ} \mathrm{C}$ for $12 \mathrm{~h}$. after cooled to room temperature the crude solution was extracted with $\mathrm{CHCl}_{3}$ twice, the organic phase was dried with $\mathrm{MgSO}_{4}$ and concentrated in vacuo. The residue was subjected to silica-gel chromatography $\left(\mathrm{CHCl}_{3} /\right.$ hexane/EtOAc $\left.=5: 1: 1\right)$ to afford $10(288 \mathrm{mg}, 83 \%$ yield $)$ as yellow solid .

${ }^{1} \mathrm{H}$ NMR $\left(500 \mathrm{MHz}, \mathrm{CDCl}_{3}\right) \delta 8.74-8.72(\mathrm{~m}, 1 \mathrm{H}), 8.69(\mathrm{~d}, J=8 \mathrm{~Hz}, 1 \mathrm{H}), 8.49-8.47(\mathrm{~m}, 1 \mathrm{H}), 8.28(\mathrm{dd}, J=9$, $1 \mathrm{~Hz}, 2 \mathrm{H}), 8.14(\mathrm{~s}, 1 \mathrm{H}), 7.90(\mathrm{~d}, J=7 \mathrm{~Hz}, 1 \mathrm{H}), 7.80(\mathrm{dd}, J=9,1 \mathrm{~Hz}, 2 \mathrm{H}), 7.76-7.70(\mathrm{~m}, 3 \mathrm{H}), 7.64(\mathrm{ddd}, J=$ 8, 7, $1 \mathrm{~Hz}, 1 \mathrm{H}) ;{ }^{13} \mathrm{C}$ NMR $\left(125 \mathrm{MHz}, \mathrm{CDCl}_{3}\right) \delta 147.1,133.0,132.3,131.0,130.72,130.68,130.3,130.1$, $128.8,128.1,127.4,127.2,127.3,126.6,123.77,123.75,123.0,122.7,118.5,93.2$, 91.9; HRMS (MALDI-TOF-MS) $\mathrm{m} / \mathrm{z}$ calcd for $\mathrm{C}_{22} \mathrm{H}_{13} \mathrm{NO}_{2}[\mathrm{M}]^{+}: 323.0941$, found: 325.0922 . 


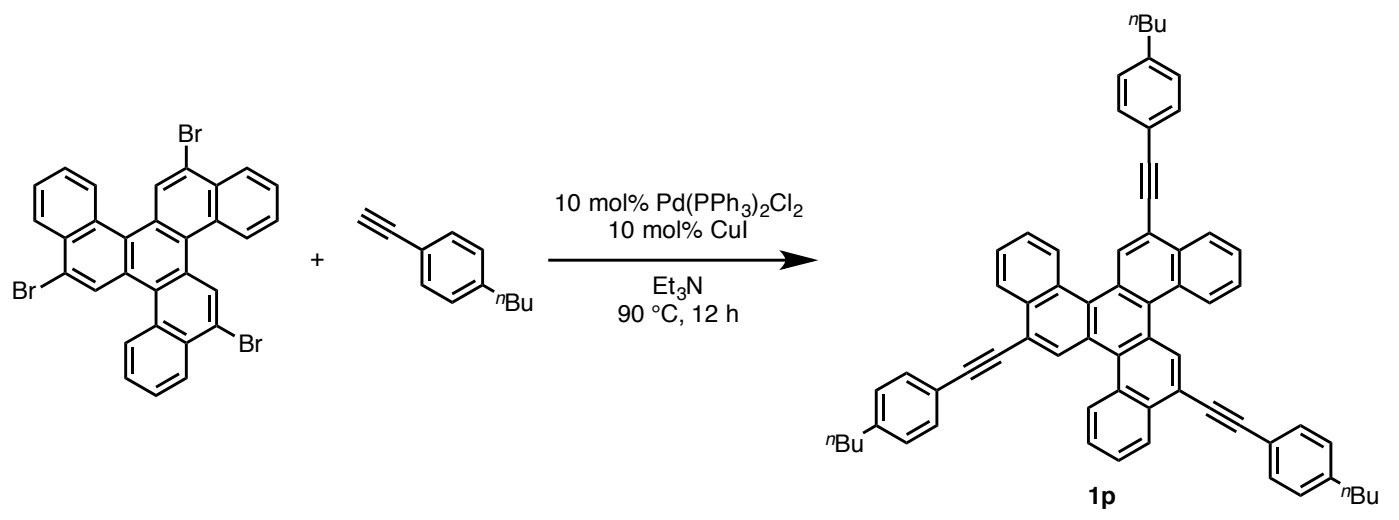

To a 50-mL Schlenk flask containing a magnetic stirring bar were added 6,12,18-tribromobenzo[c]naphtho[2,1-p]chrysene (306 mg, $500 \mu$ mol, 1.0 equiv), $\mathrm{Pd}\left(\mathrm{PPh}_{3}\right)_{2} \mathrm{Cl}_{2}(35.0 \mathrm{mg}$, $50.0 \mu \mathrm{mol}, 10 \mathrm{~mol} \%)$ and $\mathrm{CuI}(10.0 \mathrm{mg}, 50.0 \mu \mathrm{mol}, 10 \mathrm{~mol} \%)$. The flask was filled with argon, then $\mathrm{Et}_{3} \mathrm{~N}$ $(10 \mathrm{~mL})$ and 1- $n$-butyl-4-ethynylbenzene $(474 \mathrm{mg}, 3.00 \mathrm{mmol}, 6.0$ equiv) were added to the flask. The mixture was heated at $90{ }^{\circ} \mathrm{C}$ for $12 \mathrm{~h}$. The mixture was then cooled to room temperature. The crude solution was concentrated in vacuo. The residue was subjected to silica-gel chromatography $\left(\mathrm{CHCl}_{3} /\right.$ hexane $\left.=1: 10\right)$ to afford 1p (429 $\mathrm{mg}, 99 \%$ yield) as brown solid.

${ }^{1} \mathrm{H}$ NMR $\left(500 \mathrm{MHz}, \mathrm{CDCl}_{3}\right) \delta 9.11(\mathrm{~s}, 3 \mathrm{H}), 8.91-8.89(\mathrm{~m}, 3 \mathrm{H}), 8.69-8.68(\mathrm{~m}, 3 \mathrm{H}), 7.80-7.78(\mathrm{~m}, 6 \mathrm{H}), 7.63$ $(\mathrm{d}, J=8.0 \mathrm{~Hz}, 6 \mathrm{H}), 7.24(\mathrm{~d}, J=8.0 \mathrm{~Hz}, 6 \mathrm{H}), 2.68(\mathrm{t}, J=8 \mathrm{~Hz}, 6 \mathrm{H}), 1.65$ (quint, $J=7 \mathrm{~Hz}, 6 \mathrm{H}), 1.40$ (sext, $J$ $=7 \mathrm{~Hz}, 6 \mathrm{H}), 0.97(\mathrm{t}, J=7 \mathrm{~Hz}, 9 \mathrm{H}) ;{ }^{13} \mathrm{C} \mathrm{NMR}\left(125 \mathrm{MHz}, \mathrm{CDCl}_{3}\right) \delta 143.7,132.5,131.7,130.8,129.7,129.3$, 128.6, 128.2 127.4 127.0, 126.6, 126.2, 120.5, 119.2, 95.2, 87.4, 35.7, 33.4, 22.3, 13.9; HRMS (ESI-MS) $m / z$ calcd for $\mathrm{C}_{66} \mathrm{H}_{54}[\mathrm{M}+\mathrm{H}]^{+}:$847.4311, found: 847.4321 . 

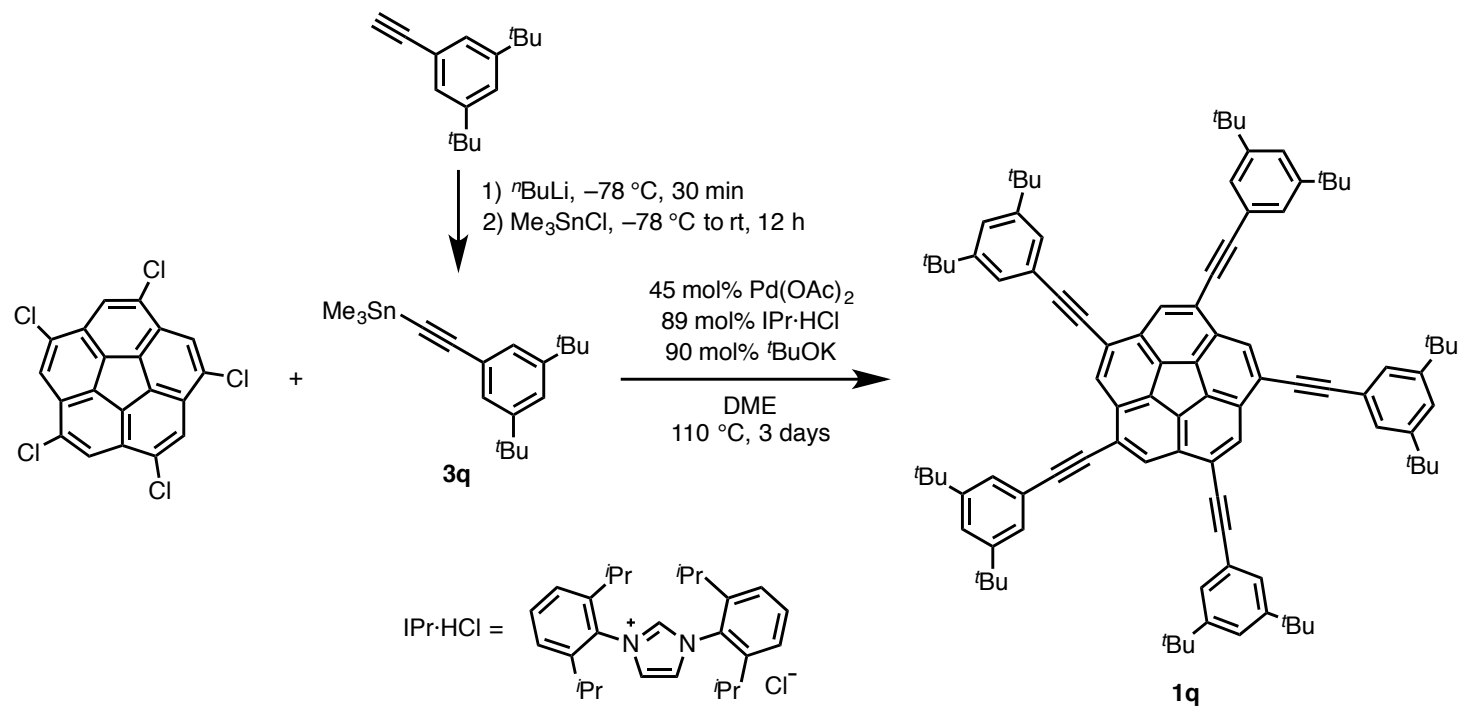

To a solution of 1,3-di-tert-butyl-5-ethynylbenzene $(2.14 \mathrm{~g}, 10.0 \mathrm{mmol})$ in THF $(50 \mathrm{~mL})$ at $-78{ }^{\circ} \mathrm{C}$ was added a hexane solution of $n$-butyllithium $(1.6 \mathrm{M}, 6.6 \mathrm{~mL}, 10.5 \mathrm{mmol})$. The mixture is stirred at $-78^{\circ} \mathrm{C}$ for $30 \mathrm{~min}$. After addition of trimethyltin chloride $(4.40 \mathrm{~g}, 11.0 \mathrm{mmol})$, the solution was warmed up to room temperature, stirred for $12 \mathrm{~h}$. The reaction mixture was quenched with water and the aqueous phase was extracted with $\mathrm{Et}_{2} \mathrm{O}(2 \times 50 \mathrm{~mL})$, and the combined organic phases were dried over $\mathrm{MgSO}_{4}$. After removal of the solvent, the product $\mathbf{3 q}$ was obtained as white solid and used without further purification.

To a 50-mL Schlenk flask containing a magnetic stirring bar were added 1,3,5,7,9-pentachlorocorannulene (220 mg, $540 \mu \mathrm{mol}, 1.0$ equiv), $\mathrm{Pd}(\mathrm{OAc})_{2}(54.0 \mathrm{mg}, 241 \mu \mathrm{mol}, 45 \mathrm{~mol} \%)$, IPr $\cdot \mathrm{HCl}(204 \mathrm{mg}, 480 \mu \mathrm{mol}, 89$ $\mathrm{mol} \%$ ), and ${ }^{t} \mathrm{BuOK}(54.0 \mathrm{mg}, 240 \mu \mathrm{mol}, 90 \mathrm{~mol} \%)$. The flask was filled with argon, then 1,2-dimethoxyethane $(25 \mathrm{~mL})$ was added to the flask and the mixture was heated at $50{ }^{\circ} \mathrm{C}$ for $30 \mathrm{~min}$. The mixture was then cooled to room temperature and $\mathbf{3 q}$ ( $2.80 \mathrm{~g}, 7.40 \mathrm{mmol}, 14.0$ equiv) was added under argon. The reaction mixture was heated at $110{ }^{\circ} \mathrm{C}$ for 3 days. The mixture was then cooled to room temperature and the crude solution concentrated in vacuo. The crude mixture was firstly filtered with $\mathrm{MeOH}$, then the residue was filtered with hexane. The filtrate was collected and concentrated in vacuo. The residue was subjected to GPC to afford 1q (270 mg, 38\%) as yellow solid.

${ }^{1} \mathrm{H}$ NMR (600 MHz, $\left.\mathrm{CDCl}_{3}\right) \delta 8.39(\mathrm{~s}, 5 \mathrm{H}), 7.58(\mathrm{~s}, 10 \mathrm{H}), 7.48(\mathrm{~s}, 5 \mathrm{H}), 1.40(\mathrm{~s}, 90 \mathrm{H}) ;{ }^{13} \mathrm{C} \mathrm{NMR}(150 \mathrm{MHz}$, $\left.\mathrm{CDCl}_{3}\right) \delta 151.1,134.8,131.3,130.8,126.2,123.4,122.5,122.0,95.6,86.1,34.9$, 31.4. HRMS (MALDI-TOF-MS) $\mathrm{m} / \mathrm{z}$ calcd for $\mathrm{C}_{100} \mathrm{H}_{110}[\mathrm{M}]^{+}:$: 1310.861, found: 1310.857 . 
Synthesis of $1 \boldsymbol{r}^{14}$

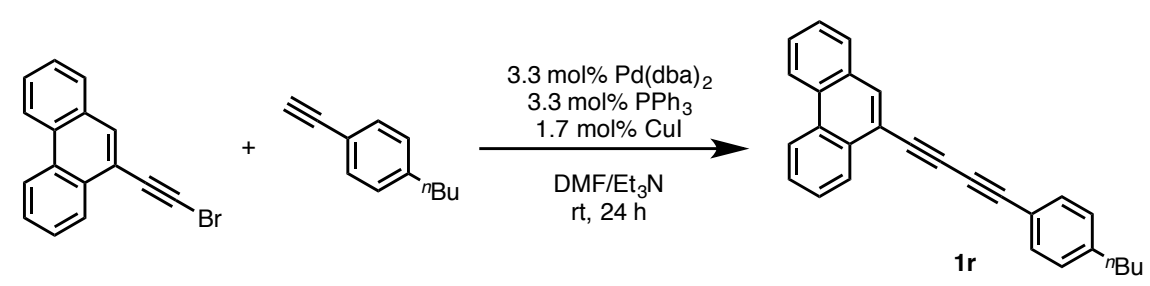

To a 10-mL Schlenk tube containing a magnetic stirring bar were added $\mathrm{Pd}(\mathrm{dba})_{2}(11.5 \mathrm{mg}, 20.0 \mu \mathrm{mol}, 3.3$ mol\%), $\mathrm{PPh}_{3}$ (5.2 mg, $20 \mu \mathrm{mol}, 3.3 \mathrm{~mol} \%$ ), CuI (1.9 mg, $10 \mu \mathrm{mol}, 1.7 \mathrm{~mol} \%$ ), and DMF (1.0 mL) under argon atmosphere. After stirred for $10 \mathrm{~min}, 1-n$-butyl-4-ethynylbenzene (95.0 mg, $600 \mu \mathrm{mol}, 1.0 \mathrm{equiv})$ and $\mathrm{Et}_{3} \mathrm{~N}(168 \mu \mathrm{L})$ were added to the tube. Then 9-(bromoethynyl)phenanthrene (281 $\mathrm{mg}, 1.00 \mathrm{mmol}, 1.7$ equiv) was added and the mixture was stirred at room temperature for $24 \mathrm{~h}$. The crude solution was concentrated in vacuo. The residue was subjected to silica-gel chromatography $\left(\mathrm{CHCl}_{3} /\right.$ hexane $\left.=1: 20\right)$ to afford $\mathbf{1 r}(102 \mathrm{mg}$, $47 \%$ yield) as white solid.

${ }^{1} \mathrm{H}$ NMR $\left(500 \mathrm{MHz}, \mathrm{CDCl}_{3}\right) \delta 8.70-8.68(\mathrm{~m}, 1 \mathrm{H}), 8.66(\mathrm{~d}, J=8 \mathrm{~Hz}, 1 \mathrm{H}), 8.11(\mathrm{~s}, 1 \mathrm{H}), 7.86(\mathrm{~d}, J=8 \mathrm{~Hz}, 1 \mathrm{H})$, $7.72-7.67(\mathrm{~m}, 3 \mathrm{H}), 7.61(\mathrm{t}, J=7 \mathrm{~Hz}, 1 \mathrm{H}), 7.51(\mathrm{~d}, J=8 \mathrm{~Hz}, 2 \mathrm{H}), 7.18(\mathrm{~d}, J=8 \mathrm{~Hz}, 2 \mathrm{H}), 2.64(\mathrm{t}, J=8 \mathrm{~Hz}$, $2 \mathrm{H}$ ), 1.62 (quint, $J=7 \mathrm{~Hz}, 2 \mathrm{H}), 1.37$ (sext, $J=7 \mathrm{~Hz}, 2 \mathrm{H}), 0.95(\mathrm{t}, J=7 \mathrm{~Hz}, 3 \mathrm{H}) ;{ }^{13} \mathrm{C}$ NMR $(125 \mathrm{MHz}$, $\left.\mathrm{CDCl}_{3}\right) \delta 144.6,133.8,132.5,131.2,130.9,130.5,130.0,128.62,128.60,127.9,127.24,127.22,127.0$, $126.9,122.8,122.6,118.8,118.4,82.9,79.8,78.4,73.6,35.7,33.3,22.3,13.9$. HRMS (MALDI-TOF-MS) $\mathrm{m} / \mathrm{z}$ calcd for $\mathrm{C}_{28} \mathrm{H}_{22}[\mathrm{M}]^{+}: 358.1716$, found: 358.1706 .

Synthesis of $1 \mathbf{s}^{9}$
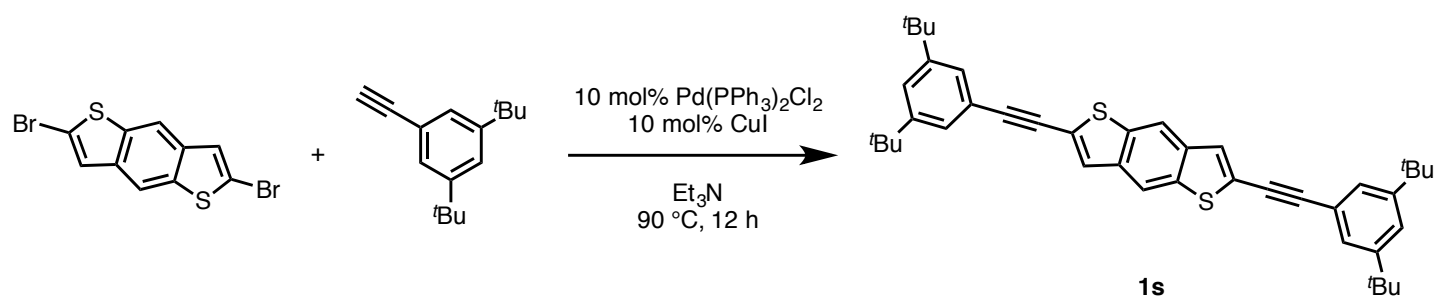

To a 50-mL Schlenk flask containing a magnetic stirring bar were added 2,6-dibromobenzo[1,2-b:4,5- $b^{\prime}$ ]dithiophene (348 mg, $1.0 \mathrm{mmol}, 1.0$ equiv), $\mathrm{Pd}\left(\mathrm{PPh}_{3}\right)_{2} \mathrm{Cl}_{2}$ (70.0 $\mathrm{mg}, 100$ $\mu \mathrm{mol}, 10 \mathrm{~mol} \%)$, and $\mathrm{CuI}(20.0 \mathrm{mg}, 100 \mathrm{~mol}, 10 \mathrm{~mol} \%)$. The flask was filled with argon, then $\mathrm{Et}_{3} \mathrm{~N}(10 \mathrm{~mL})$ and 1,3-di-t-butyl-5-ethynylbenzene $(642 \mathrm{mg}, 3.00 \mathrm{mmol}, 3.0$ equiv) were added to the flask. The mixture was heated at $90{ }^{\circ} \mathrm{C}$ for $12 \mathrm{~h}$. The mixture was then cooled to room temperature. The crude solution was concentrated in vacuo. The residue was subjected to silica-gel chromatography $\left(\mathrm{CHCl}_{3} /\right.$ hexane $\left.=1: 10\right)$ to afford $1 \mathrm{~s}$ (393 $\mathrm{mg}, 64 \%$ yield) as yellow solid.

${ }^{1} \mathrm{H}$ NMR $\left(500 \mathrm{MHz}, \mathrm{CDCl}_{3}\right) \delta 8.15$ (s, 2H), 7.53 (s, 2H), 7.45 (s, 2H), $7.42(\mathrm{~s}, 4 \mathrm{H}), 1.36(\mathrm{~s}, 36 \mathrm{H}) ;{ }^{13} \mathrm{C} \mathrm{NMR}$ $\left(125 \mathrm{MHz}, \mathrm{CDCl}_{3}\right) \delta 151.0,137.8,127.5,125.9,124.4,123.4,121.4,116.3,96.9,81.9,34.9,31.3 . \mathrm{HRMS}$ (MALDI-TOF-MS) $m / z$ calcd for $\mathrm{C}_{42} \mathrm{H}_{46} \mathrm{~S}_{2}[\mathrm{M}]^{+}: 614.3035$, found: 614.3024 . 
Synthesis of $\mathbf{1} \boldsymbol{t}^{9}$
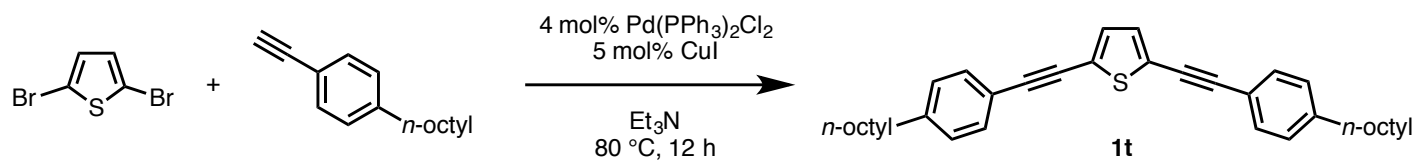

To a $100-\mathrm{mL}$ Schlenk flask containing a magnetic stirring bar were added 2,6-dibromothiophene (1.21 g, 5.0 mmol, 1.0 equiv), $\mathrm{Pd}\left(\mathrm{PPh}_{3}\right)_{2} \mathrm{Cl}_{2}(140 \mathrm{mg}, 200 \mu \mathrm{mol}, 4.0 \mathrm{~mol} \%)$ and $\mathrm{CuI}(40.0 \mathrm{mg}, 50.0 \mu \mathrm{mol}, 5.0 \mathrm{~mol} \%)$. The flask was filled with argon, then $\mathrm{Et}_{3} \mathrm{~N}(50 \mathrm{~mL})$ and 1-ethynyl-4-octylbenzene $(2.57 \mathrm{~g}, 25.0 \mathrm{mmol}, 5.0$ equiv) were added to the flask. The mixture was heated at $80{ }^{\circ} \mathrm{C}$ for $12 \mathrm{~h}$. The mixture was then cooled to room temperature. The crude solution was concentrated in vacuo. The residue was subjected to silica-gel chromatography $\left(\mathrm{CHCl}_{3} /\right.$ hexane $\left.=1: 20\right)$ to afford $1 \mathrm{t}(1.57 \mathrm{~g}, 62 \%$ yield $)$ as yellow solid.

${ }^{1} \mathrm{H}$ NMR $\left(500 \mathrm{MHz}, \mathrm{CDCl}_{3}\right) \delta 7.43(\mathrm{~d}, J=8 \mathrm{~Hz}, 4 \mathrm{H}), 7.16(\mathrm{~d}, J=8 \mathrm{~Hz}, 4 \mathrm{H}), 7.13(\mathrm{~s}, 2 \mathrm{H}), 2.61(\mathrm{t}, J=7 \mathrm{~Hz}$, $4 \mathrm{H}), 1.61$ (quint, $J=7 \mathrm{~Hz}, 4 \mathrm{H}), 1.33-1.24(\mathrm{~m}, 20 \mathrm{H}), 0.88(\mathrm{t}, J=7 \mathrm{~Hz}, 6 \mathrm{H}) ;{ }^{13} \mathrm{C} \mathrm{NMR}\left(125 \mathrm{MHz}, \mathrm{CDCl}_{3}\right) \delta$ $143.9,131.5,131.4,128.5,124.7,119.7,94.2,81.7,35.9,31.9,31.2,29.4,29.2,22.7,14.1$. HRMS (MALDI-TOF-MS) $\mathrm{m} / \mathrm{z}$ calcd for $\mathrm{C}_{36} \mathrm{H}_{44} \mathrm{~S}[\mathrm{M}]^{+}: 508.3158$, found: 508.3138 . 


\section{X-ray Crystallography}

Details of the crystal data and a summary of the intensity data collection parameters are listed in Table S1. In each case, a suitable crystal was mounted with mineral oil on a glass fiber and transferred to the goniometer of a Rigaku PILATUS diffractometer. Graphite-monochromated Mo Ka radiation was used. The structures were solved by direct methods with (SIR-97) ${ }^{15}$ and refined by full-matrix least-squares techniques against $F^{2}$ (SHELXL-97). ${ }^{16}$ The intensities were corrected for Lorentz and polarization effects. The non-hydrogen atoms were refined anisotropically. Hydrogen atoms were placed using AFIX instructions.

Table S2. Crystallographic Data and Structure Refinement Details

\begin{tabular}{lllll}
\hline & $\mathbf{2 a}$ & $\mathbf{2 e}$ & $\mathbf{2 j}$ & $\mathbf{2 m}$ \\
\hline formula & $\mathrm{C}_{26} \mathrm{H}_{22} \mathrm{~S}$ & $\mathrm{C}_{22} \mathrm{H}_{10} \mathrm{BrS}$ & $\mathrm{C}_{34} \mathrm{H}_{32} \mathrm{~S}$ & $\mathrm{C}_{46} \mathrm{H}_{44} \mathrm{~S}_{2}$ \\
fw & 366.50 & 395.34 & 504.72 & 660.93 \\
$T(\mathrm{~K})$ & $123(2)$ & $123(2)$ & $123(2)$ & $123(2)$ \\
$\lambda(\AA)$ & 0.71075 & 0.71075 & 0.71075 & 0.71073 \\
cryst syst & Monoclinic & Orthorhombic & Monoclinic & Triclinic \\
space group & $I 2$ & $P 2_{1} 2_{1} 2_{1}$ & $P 2_{1} / n$ & $P-1$ \\
$a(\AA)$ & $18.49(3)$ & $4.0008(15)$ & $19.7473(10)$ & $7.6703(6)$ \\
$b(\AA)$ & $6.052(7)$ & $17.707(7)$ & $5.6750(2)$ & $21.0804(8)$ \\
$c(\AA)$ & $19.25(3)$ & $24.219(11)$ & $23.7866(11)$ & $22.2882(9)$ \\
$\alpha($ deg $)$ & 90 & 90 & 90 & $70.261(4)$ \\
$\beta($ deg $)$ & $118.64(3)$ & 90 & $103.491(5)$ & $80.257(5)$ \\
$\gamma($ deg $)$ & 90 & 90 & 90 & $89.482(5)$ \\
$V\left(\AA^{3}\right)$ & $1891(5)$ & $1715.7(12)$ & $2592.1(2)$ & $3338.7(3)$ \\
$Z$ & 4 & 4 & 4 & 4 \\
$D_{\text {calc }}\left(\mathrm{g} / \mathrm{cm}^{3}\right)$ & 1.288 & 1.531 & 1.293 & 1.315 \\
$\left.\mu(\mathrm{mm})^{-1}\right)$ & 0.179 & 2.517 & 0.228 & 0.194 \\
$F(000)$ & 776 & 808 & 1072 & 1408 \\
cryst size $(\mathrm{mm})$ & $0.25 \times 0.01 \times 0.01$ & $0.20 \times 0.05 \times 0.05$ & $0.15 \times 0.02 \times 0.02$ & $0.02 \times 0.02 \times 0.02$ \\
$\theta$ range $($ deg $)$ & $3.21-25.00$ & $3.36-25.00$ & $1.76-25.00$ & $1.89-25.00$ \\
reflns collected & 11537 & 10485 & 14632 & 53295 \\
indep reflns $/ R_{\text {int }}$ & $3277 / 0.2417$ & $3005 / 0.0619$ & $4495 / 0.0625$ & $40920 / 0.0760$ \\
params & 272 & 218 & 327 & 869 \\
GOF on $\mathrm{F}^{2}$ & 1.057 & 0.948 & 1.035 & 1.037 \\
$R_{1}, w R_{2}[I>2 \sigma(I)]$ & $0.0804,0.1847$ & $0.0326,0.0674$ & $0.0538,0.1305$ & $0.0998,0.2443$ \\
$R_{1}, w R_{2}($ all data $)$ & $0.1901,0.2849$ & $0.0389,0.0690$ & $0.1026,0.1677$ & $0.1680,0.3031$ \\
\hline & & & &
\end{tabular}




\begin{tabular}{|c|c|c|c|c|}
\hline & $2 \mathbf{p}$ & $2 q$ & $2 \mathbf{r}$ & $2 s$ \\
\hline $\begin{array}{l}\text { formula } \\
\text { fw }\end{array}$ & $\begin{array}{l}\mathrm{C}_{66} \mathrm{H}_{54} \mathrm{~S}_{3} \\
943.27\end{array}$ & $\begin{array}{l}\mathrm{C}_{211} \mathrm{H}_{228} \mathrm{~S}_{10} \\
3084.53\end{array}$ & $\begin{array}{l}\mathrm{C}_{28} \mathrm{H}_{22} \mathrm{~S}_{2} \\
422.58\end{array}$ & $\begin{array}{l}\mathrm{C}_{42} \mathrm{H}_{46} \mathrm{~S}_{4} \\
679.03\end{array}$ \\
\hline$T(\mathrm{~K})$ & $123(2)$ & $123(2)$ & $123(2)$ & $123(2)$ \\
\hline$\lambda(\check{A})$ & 0.71073 & 0.71075 & 0.71075 & 0.71075 \\
\hline cryst syst & Monoclinic & Monoclinic & Monoclinic & Triclinic \\
\hline space group & $P 2_{1} / c$ & $P 2_{1} / c$ & $C 2 / c$ & $P-1$ \\
\hline$a(\breve{\mathrm{A}})$ & $10.6685(10)$ & $19.9874(5)$ & $20.0313(15)$ & $5.8732(9)$ \\
\hline$b(\breve{A})$ & $31.183(3)$ & $27.2493(6)$ & $5.4916(3)$ & $9.5089(14)$ \\
\hline$c(\stackrel{\mathrm{A}}{)})$ & $15.5232(17)$ & $37.9721(9)$ & $38.068(3)$ & $16.609(3)$ \\
\hline$\alpha(\mathrm{deg})$ & 90 & 90 & 90 & $81.082(8)$ \\
\hline$\beta(\operatorname{deg})$ & $106.984(2)$ & $103.491(2)$ & $101.739(3)$ & $86.233(7)$ \\
\hline$\gamma(\operatorname{deg})$ & 90 & 90 & 90 & $81.513(8)$ \\
\hline$V\left(\breve{A}^{3}\right)$ & 4939.0(9) & $20110.6(8)$ & $4100.0(5)$ & $905.5(3)$ \\
\hline$Z$ & 4 & 4 & 8 & 1 \\
\hline$D_{\text {calc }}\left(\mathrm{g} / \mathrm{cm}^{3}\right)$ & 1.269 & 1.019 & 1.369 & 1.245 \\
\hline$\mu\left(\mathrm{mm}^{-1}\right)$ & 0.193 & 0.157 & 0.273 & 0.292 \\
\hline$F(000)$ & 1992 & 6616 & 1776 & 362 \\
\hline cryst size (mm) & $0.20 \times 0.20 \times 0.05$ & $0.05 \times 0.05 \times 0.02$ & $0.20 \times 0.10 \times 0.01$ & $0.20 \times 0.10 \times 0.05$ \\
\hline$\theta$ range $(\mathrm{deg})$ & $3.29-25.00$ & $1.82-25.00$ & $3.28-25.00$ & $3.06-25.00$ \\
\hline reflns collected & 53295 & 241139 & 26906 & 10065 \\
\hline indep reflns $/ R_{\text {int }}$ & $8556 / 0.0432$ & $35410 / 0.1576$ & $3576 / 0.1058$ & $3148 / 0.0689$ \\
\hline params & 688 & 2254 & 272 & 214 \\
\hline $\mathrm{GOF}$ on $\mathrm{F}^{2}$ & 1.211 & 1.552 & 1.009 & 1.010 \\
\hline$R_{1}, w R_{2}[I>2 \sigma(I)]$ & $0.0588,0.1478$ & $0.1753,0.4409$ & $0.0497,0.1161$ & $0.0550,0.1500$ \\
\hline$R_{1}, w R_{2}$ (all data) & $0.0818,0.1843$ & $0.2783,0.4905$ & $0.0626,0.1211$ & $0.0665,0.1553$ \\
\hline
\end{tabular}




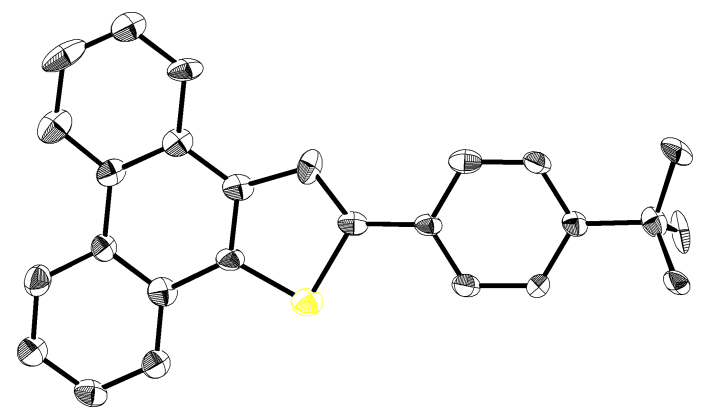

Figure S1. ORTEP drawing of 2a with 50\% probability. All hydrogen atoms are omitted for clarity.

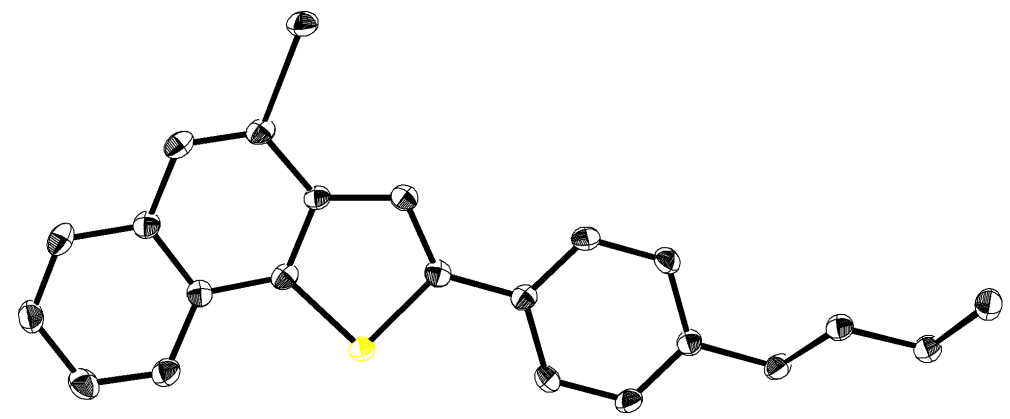

Figure S2. ORTEP drawing of $\mathbf{2 e}$ with $50 \%$ probability. All hydrogen atoms are omitted for clarity.

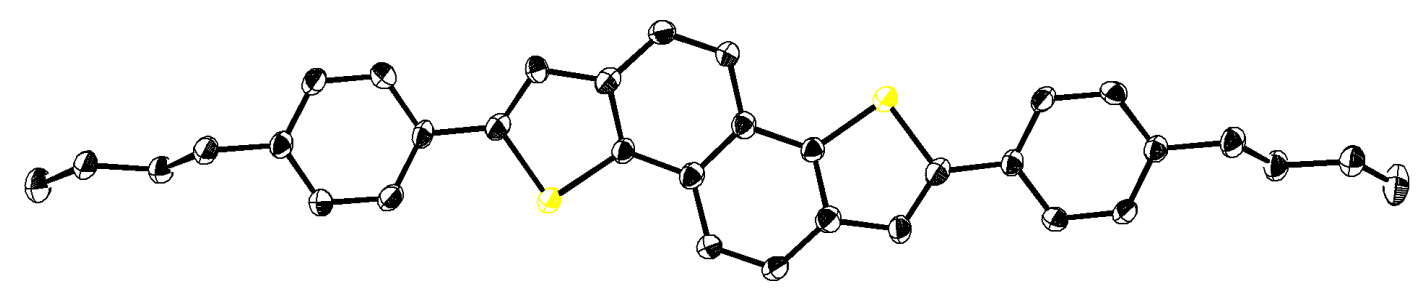

Figure S3. ORTEP drawing of $\mathbf{2} \mathbf{j}$ with $50 \%$ probability. All hydrogen atoms are omitted for clarity.

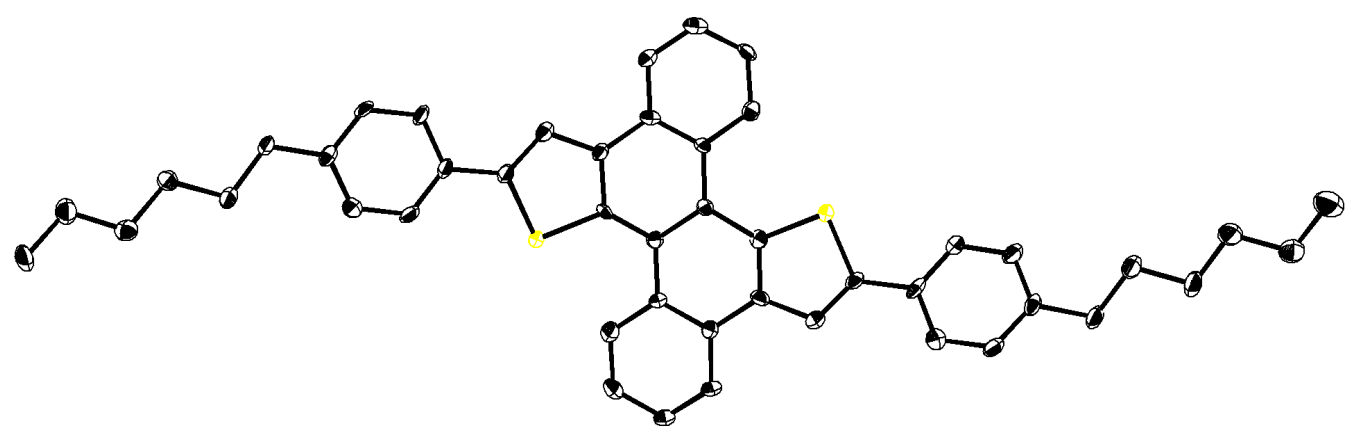

Figure S4. ORTEP drawing of $\mathbf{2 m}$ with $50 \%$ probability. All hydrogen atoms are omitted for clarity. 


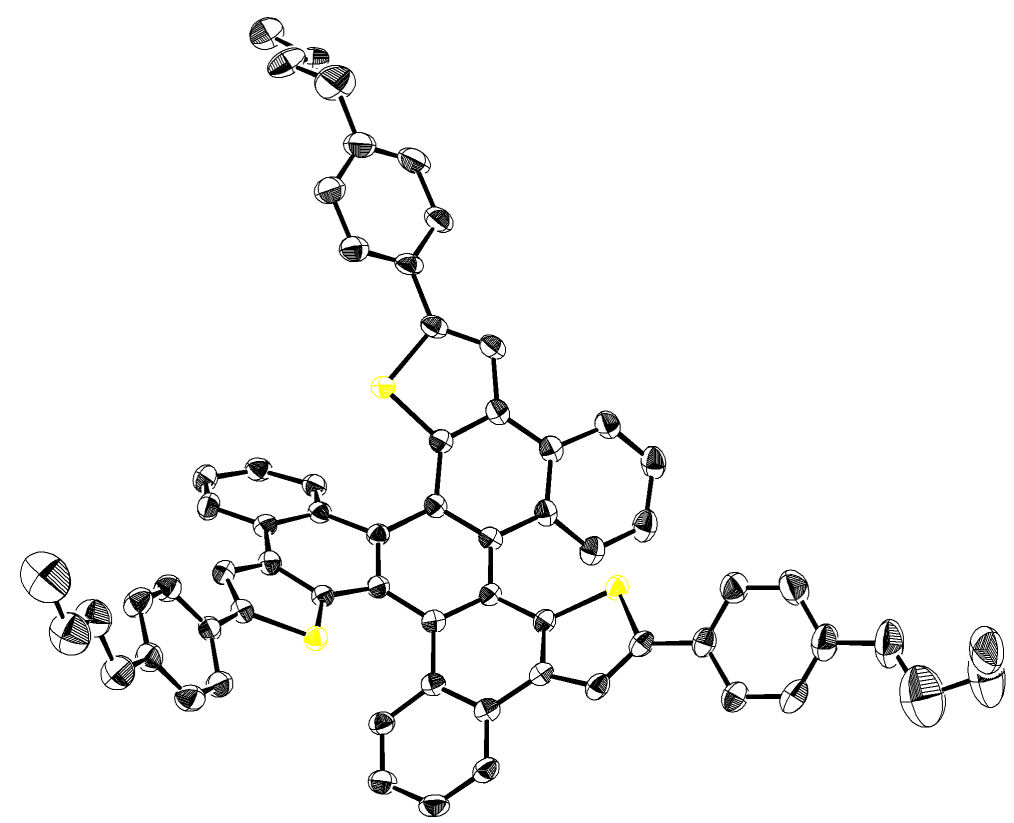

Figure S5. ORTEP drawing of $\mathbf{2 p}$ with $50 \%$ probability. All hydrogen atoms are omitted for clarity.

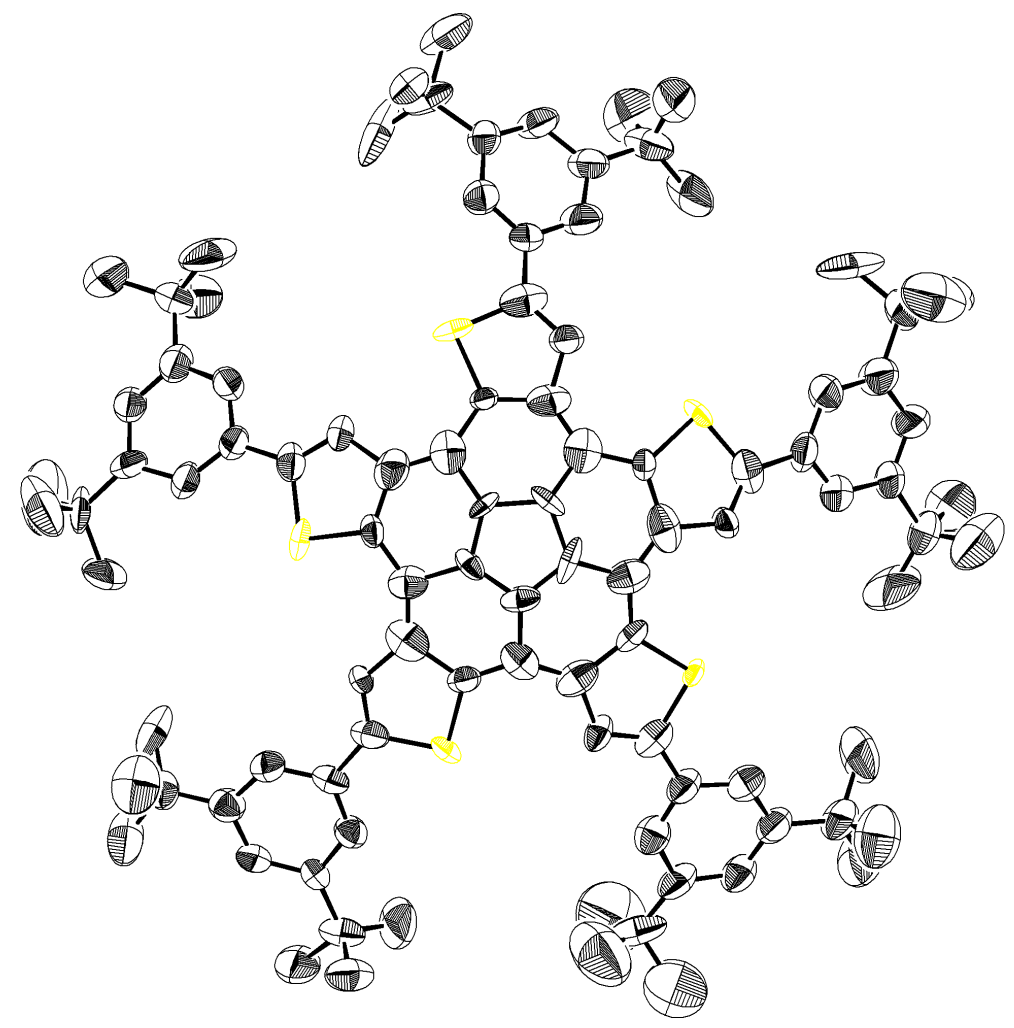

Figure S6. ORTEP drawing of $\mathbf{2 q}$ with $50 \%$ probability. All hydrogen atoms are omitted for clarity. 


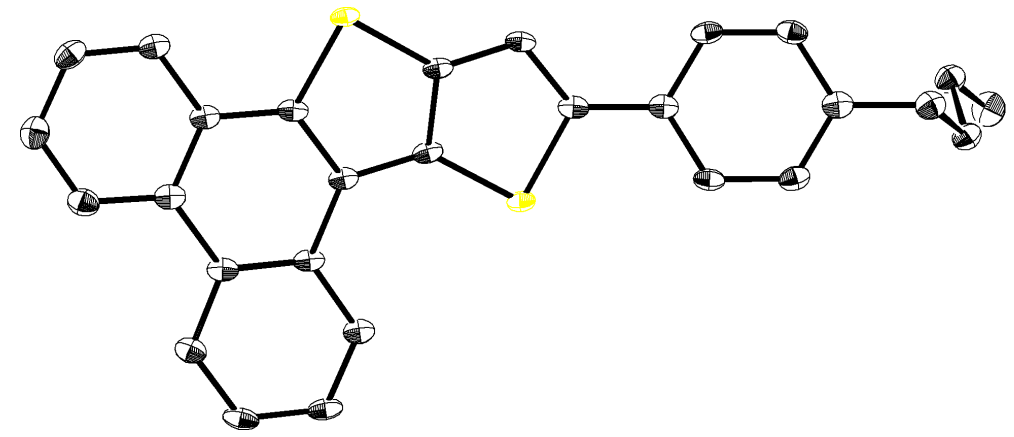

Figure S7. ORTEP drawing of $\mathbf{2 r}$ with $50 \%$ probability. All hydrogen atoms are omitted for clarity.

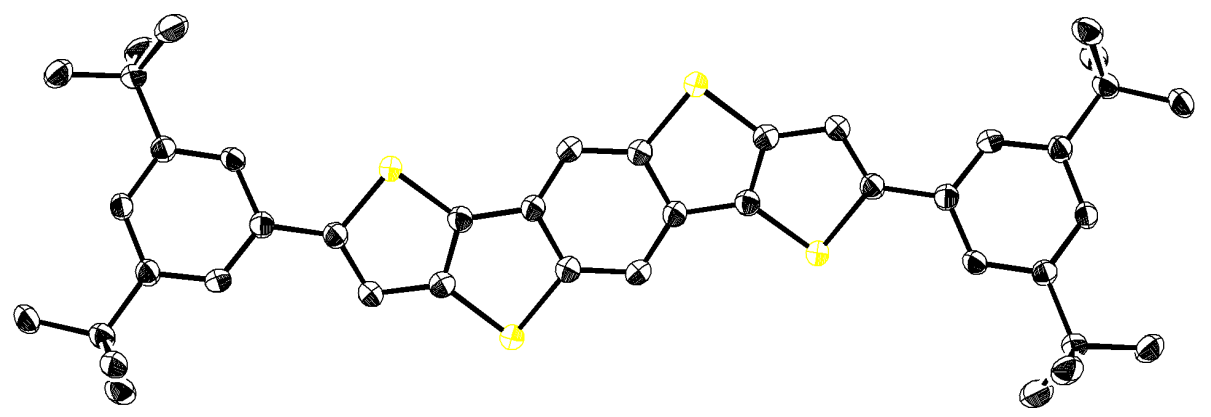

Figure S8. ORTEP drawing of 2 s with $50 \%$ probability. All hydrogen atoms are omitted for clarity. 


\section{Photophysical Properties}

Dilute solutions in degassed spectral grade dichloromethane in a $1 \mathrm{~cm}$ square quartz cell were used for all measurements. UV-vis absorption spectra were recorded on a Shimadzu UV-3510 spectrometer with a resolution of $0.5 \mathrm{~nm}$. Emission spectra were measured with an F-4500 Hitachi spectrometer or Shimadzu RF-6000 with a resolution of $0.4 \mathrm{~nm}$. Absolute fluorescence quantum yields $\left(\Phi_{\mathrm{F}}\right)$ were determined with Shimadzu RF-6000 with calibrated integrating sphere system (207-21460-41). Circular dichroism spectra were measured with a JASCO FT/IR6100.

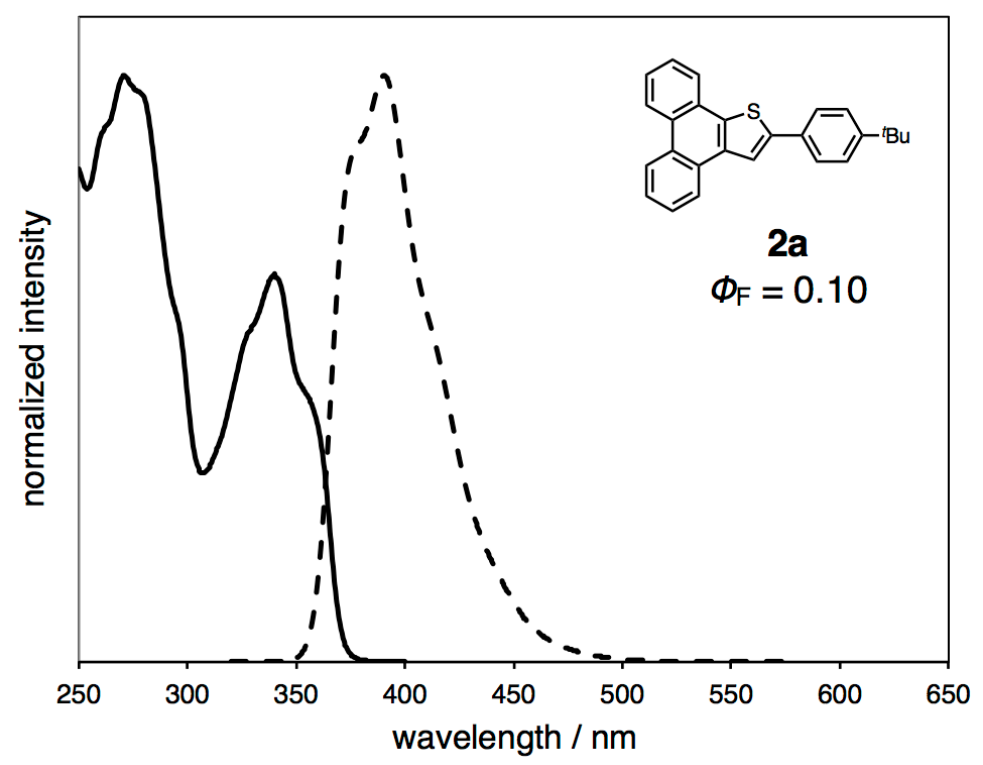

Figure S9. Absorption (solid line) and fluorescence (broken line) spectra of 2a.

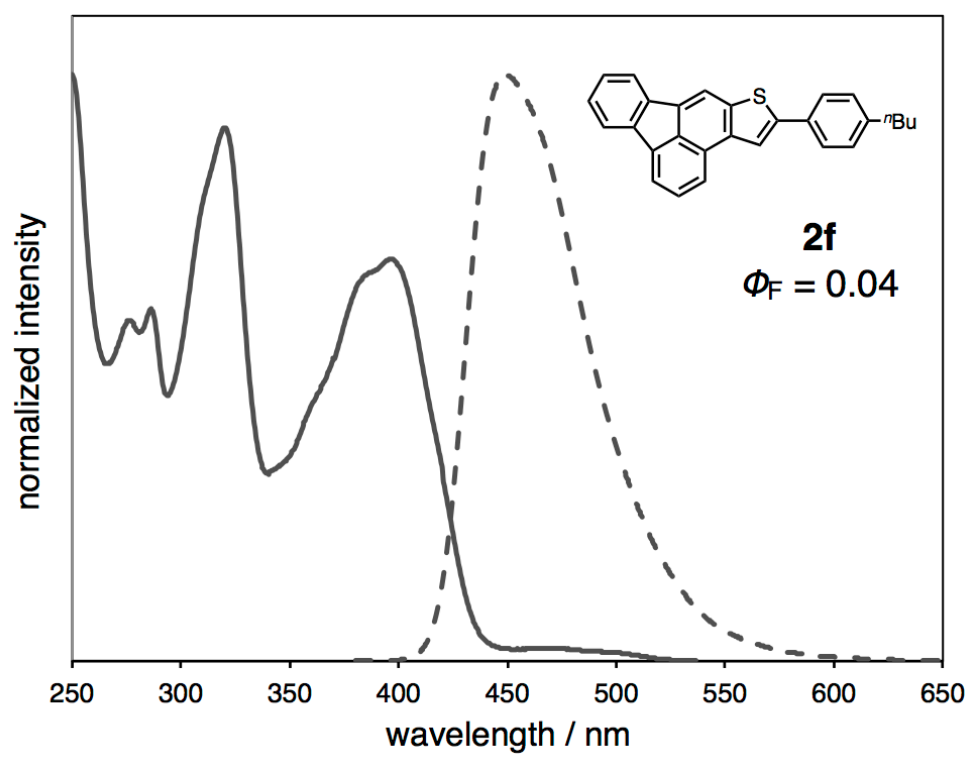

Figure S10. Absorption (solid line) and fluorescence (broken line) spectra of $\mathbf{2 f}$. 


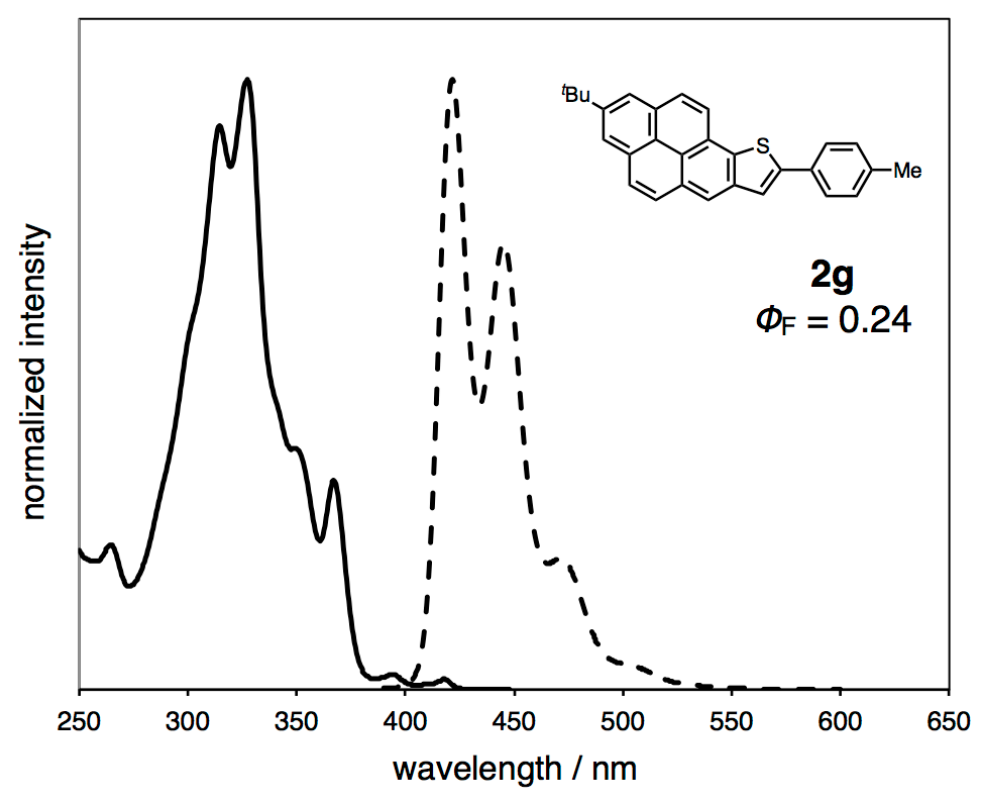

Figure S11. Absorption (solid line) and fluorescence (broken line) spectra of $\mathbf{2 g}$.

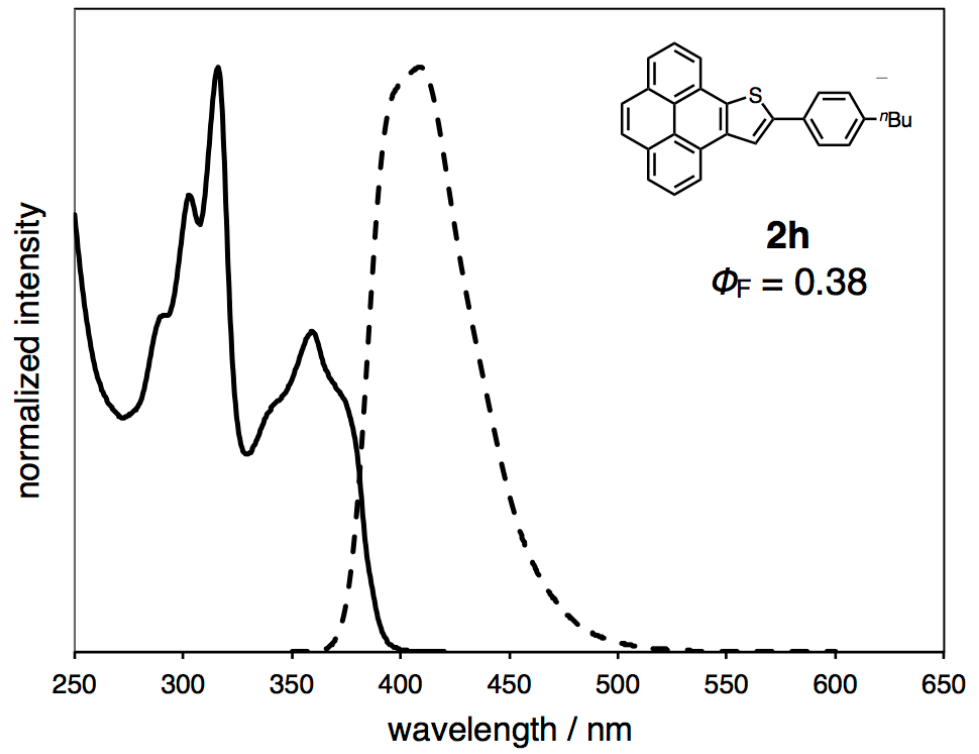

Figure S12. Absorption (solid line) and fluorescence (broken line) spectra of $\mathbf{2 h}$. 


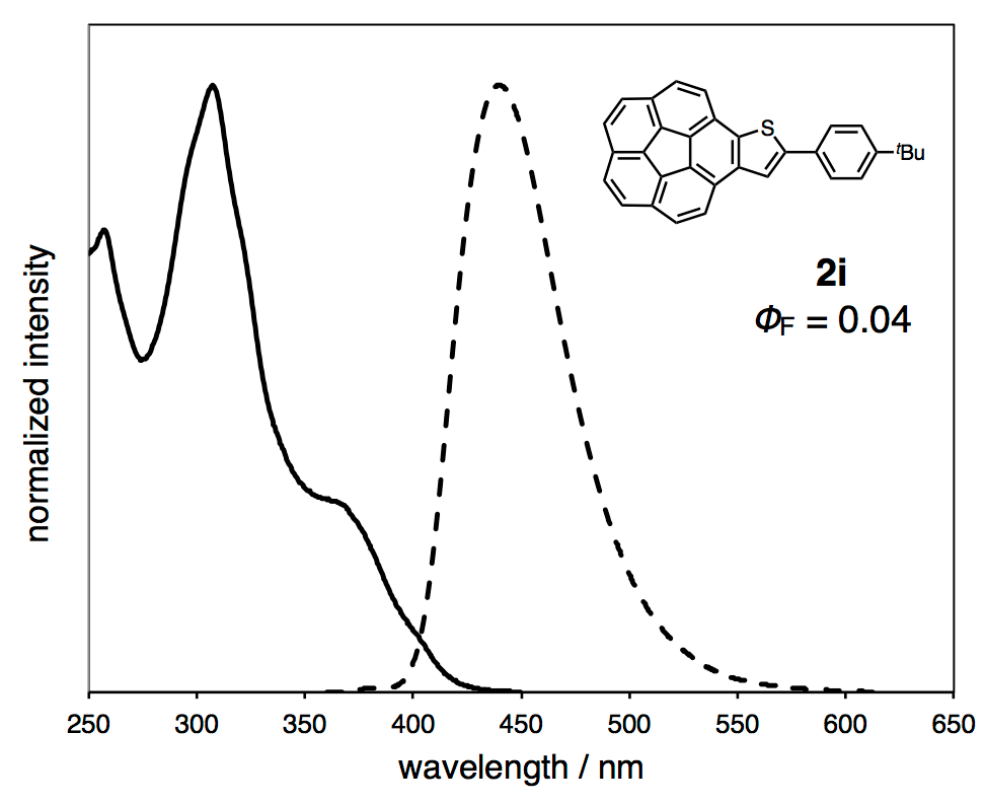

Figure S13. Absorption (solid line) and fluorescence (broken line) spectra of $\mathbf{2 i}$.

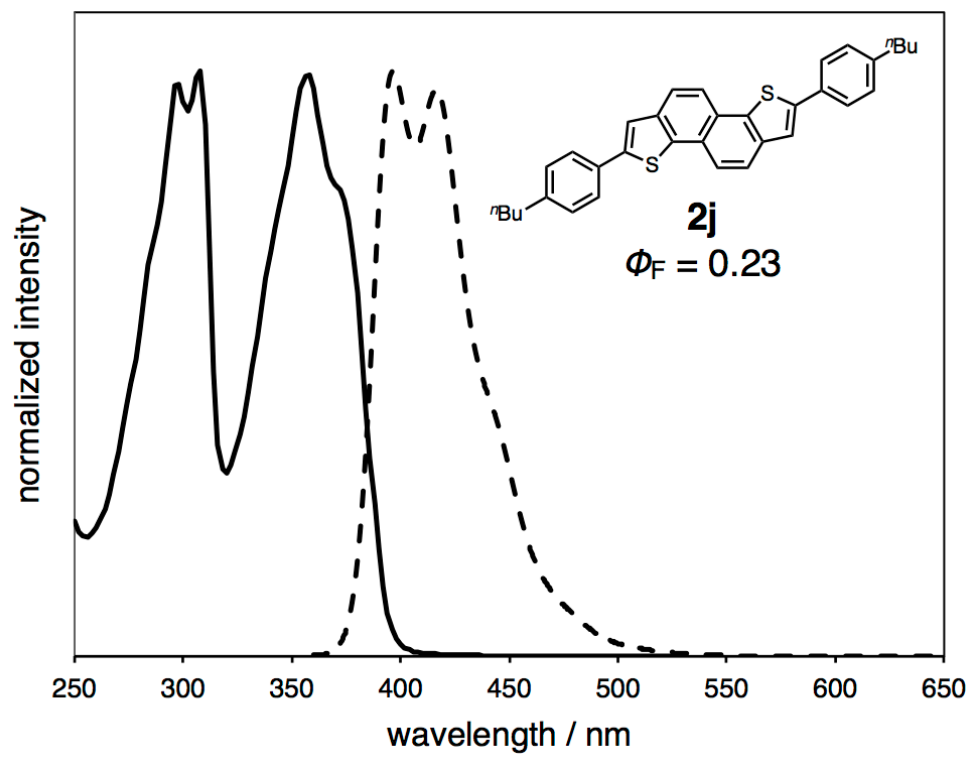

Figure S14. Absorption (solid line) and fluorescence (broken line) spectra of $\mathbf{2 j}$. 


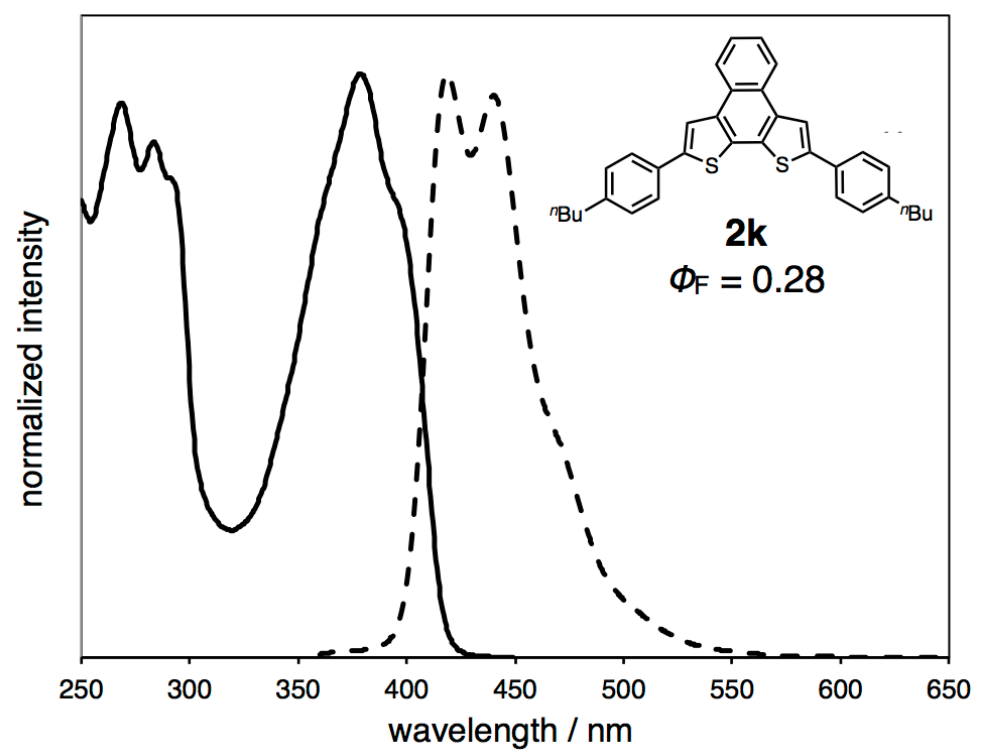

Figure S15. Absorption (solid line) and fluorescence (broken line) spectra of $\mathbf{2 k}$.

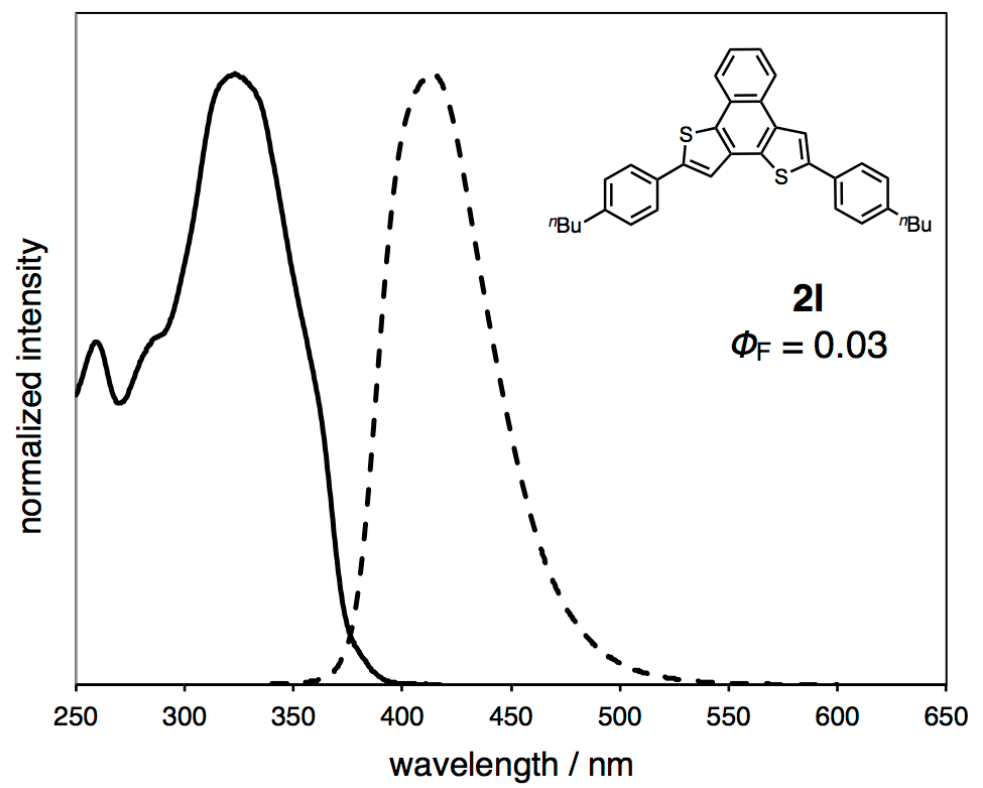

Figure S16. Absorption (solid line) and fluorescence (broken line) spectra of 21. 


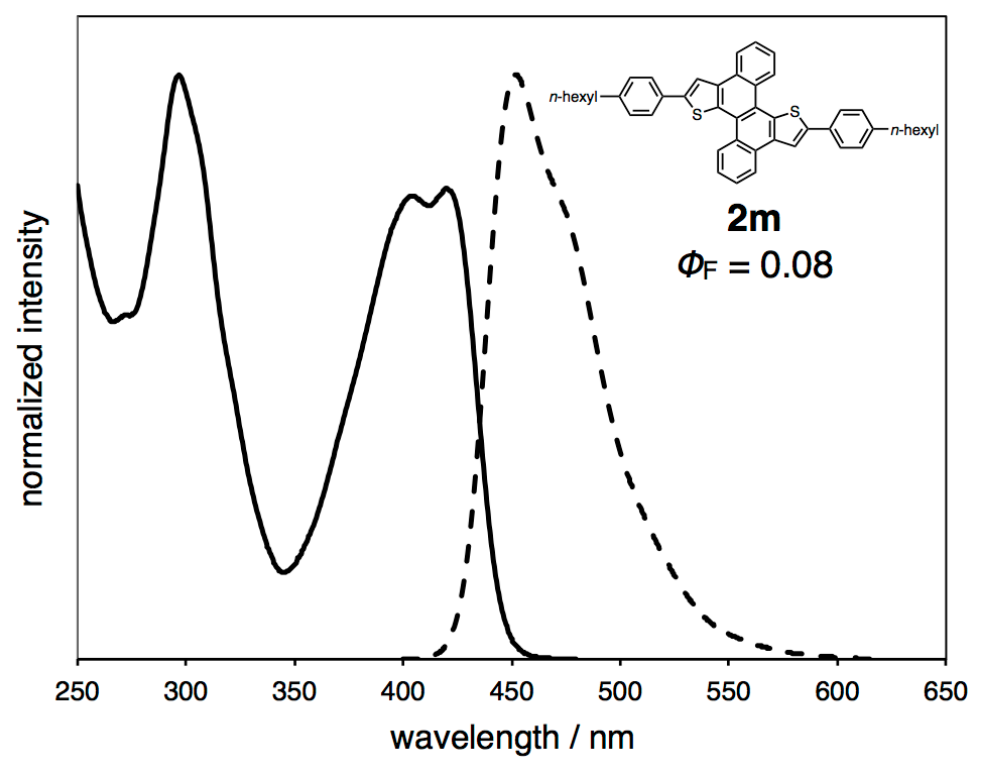

Figure S17. Absorption (solid line) and fluorescence (broken line) spectra of $\mathbf{2 m}$.

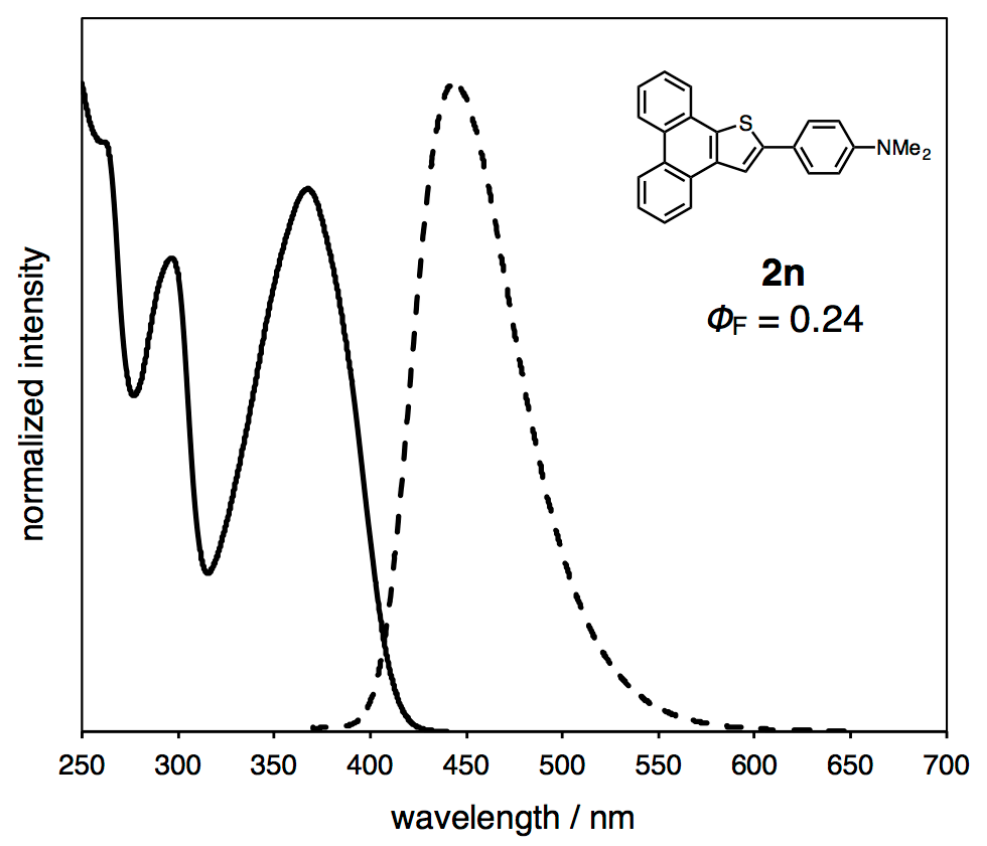

Figure S18. Absorption (solid line) and fluorescence (broken line) spectra of $\mathbf{2 n}$. 


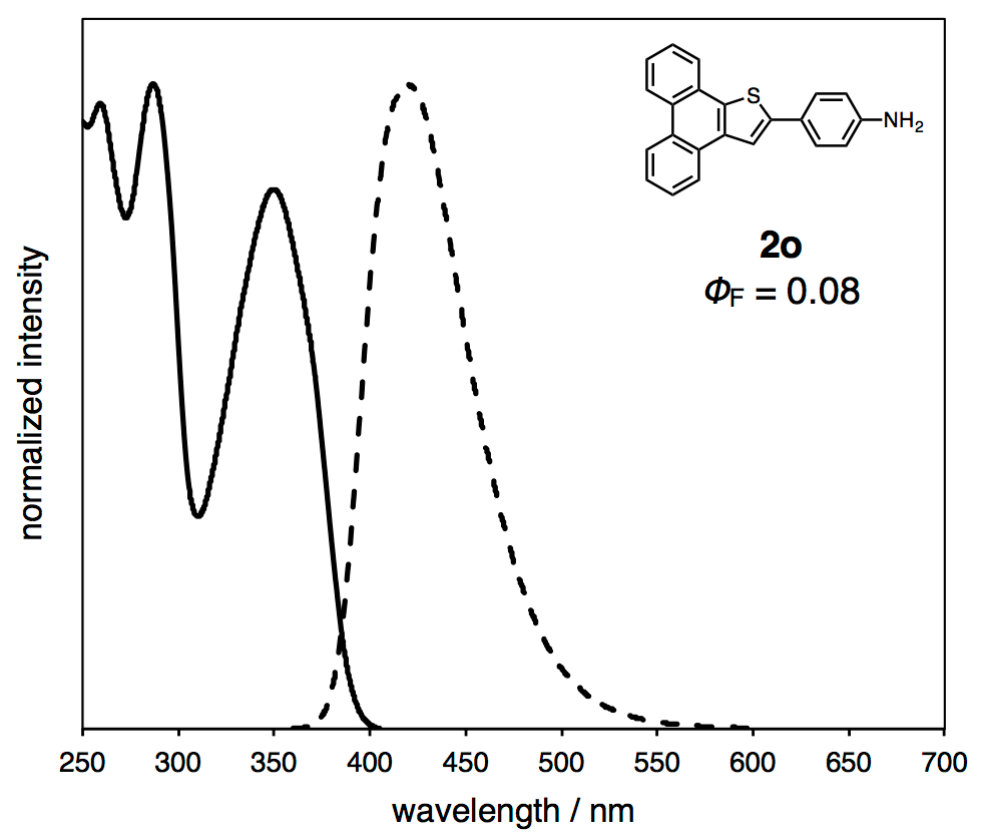

Figure S19. Absorption (solid line) and fluorescence (broken line) spectra of 20.

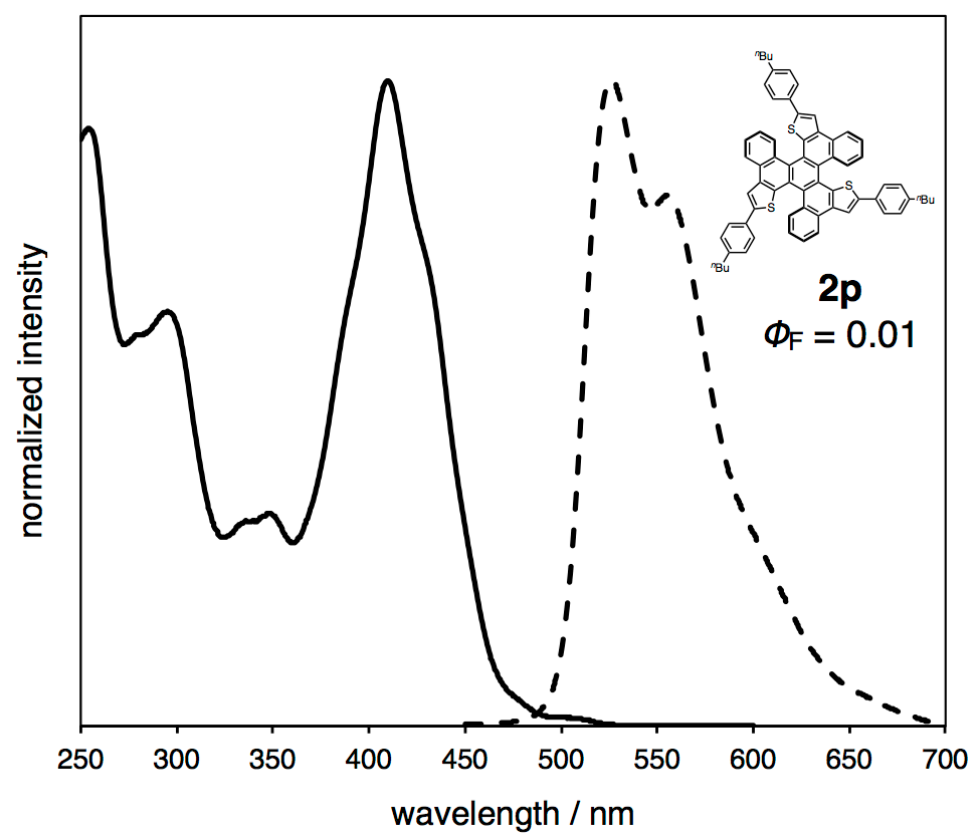

Figure S20. Absorption (solid line) and fluorescence (broken line) spectra of $\mathbf{2 p}$. 


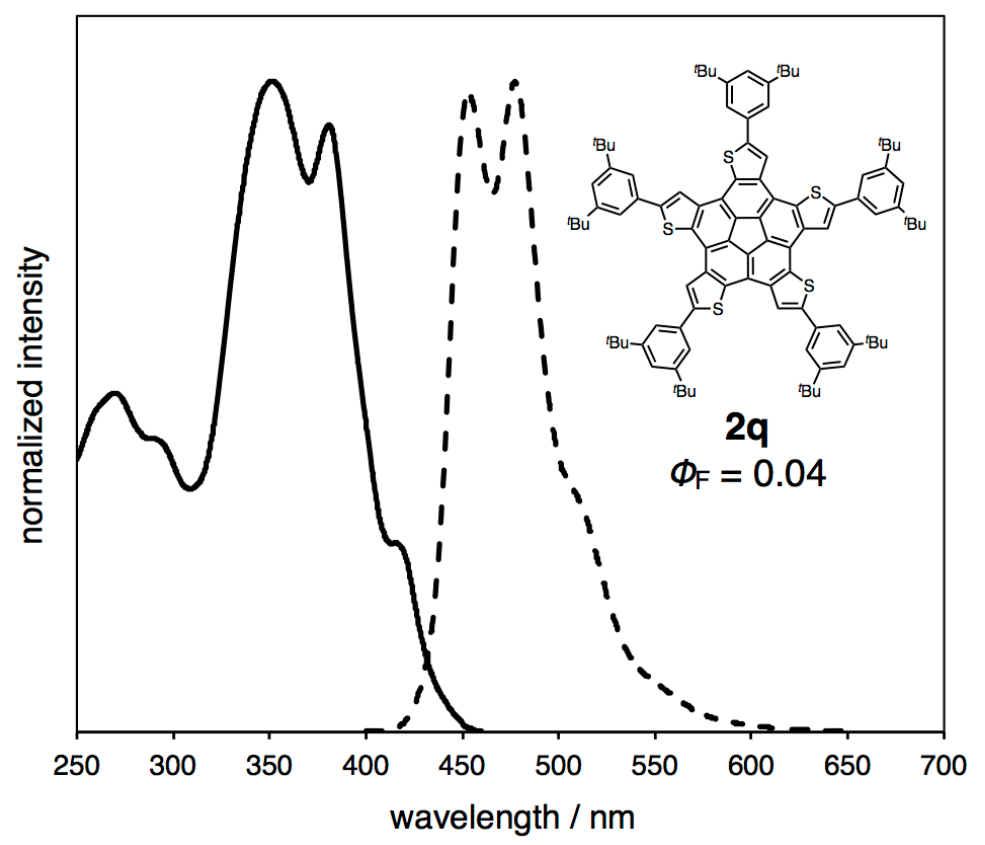

Figure S21. Absorption (solid line) and fluorescence (broken line) spectra of 2q.

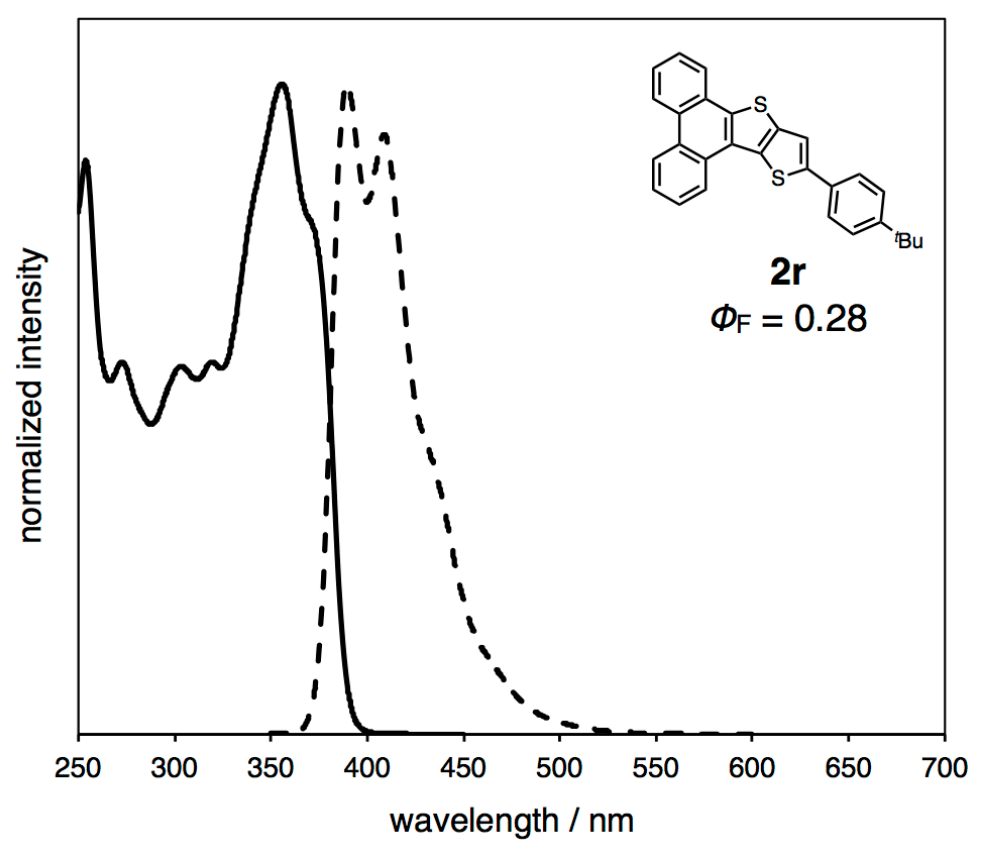

Figure S22. Absorption (solid line) and fluorescence (broken line) spectra of $\mathbf{2 r}$. 


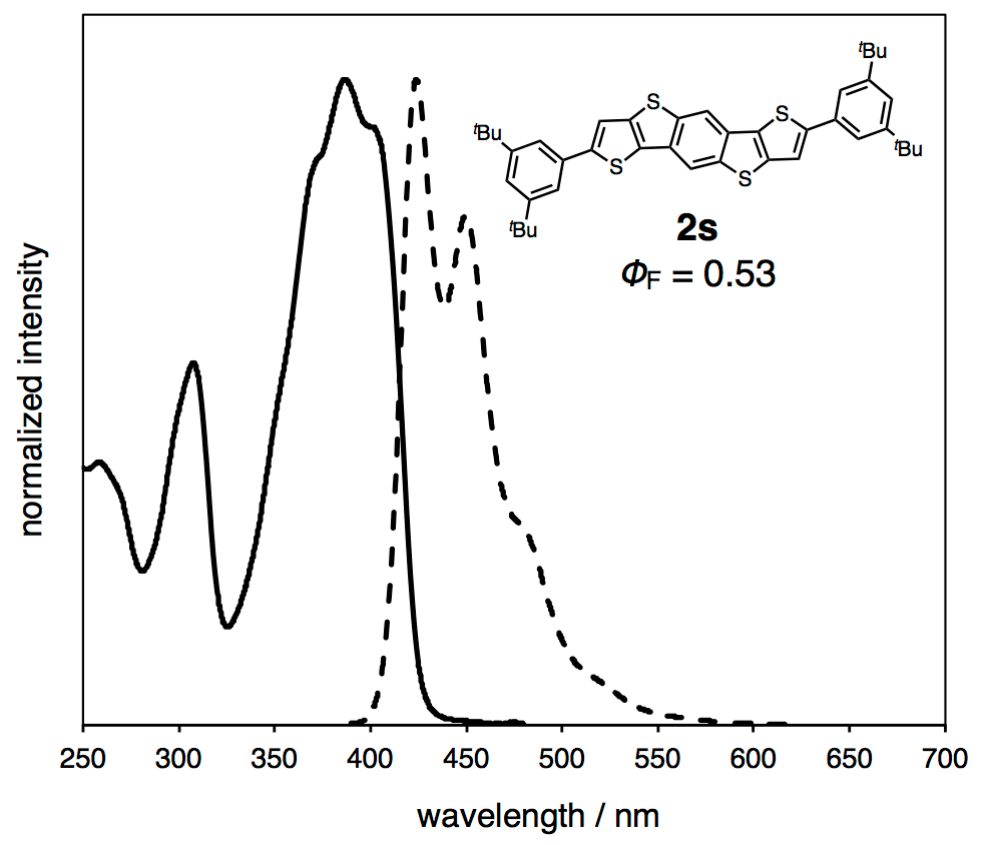

Figure S23. Absorption (solid line) and fluorescence (broken line) spectra of $\mathbf{2 s .}$ 


\section{Kinetic Study}

Separation of the enantiomers of $\mathbf{2 p}$ was conducted on a Shimadzu Prominence 2000 instrument equipped with COSMOSIL Cholester column using chloroform/methanol $=3: 7$ as an eluent. Kinetics of the racemization of $\mathbf{2 p}$ were studied by monitoring the decreasing ellipticity ([$[\theta])$ in the CD spectra in 1,2-dichloroethane at $164.5,173.5$, and $183.8^{\circ} \mathrm{C}$ (Figure S12). All reactions were conducted in test tube upon the heating by oil bath under nitrogen. Reactions were stopped at each time for the CD measurement by cooling the test tube in ice bath. The kinetic parameters of racemization of $\mathbf{2} \mathbf{p}$ were estimated to be $\Delta H^{*}=$ $24.8 \mathrm{kcal} / \mathrm{mol}, \Delta S^{\ddagger}=0.44 \mathrm{cal} /(\mathrm{mol} \cdot \mathrm{K})$, and $\Delta G^{\ddagger}=24.7 \mathrm{kcal} / \mathrm{mol}(298.15 \mathrm{~K}, 1 \mathrm{~atm})$.
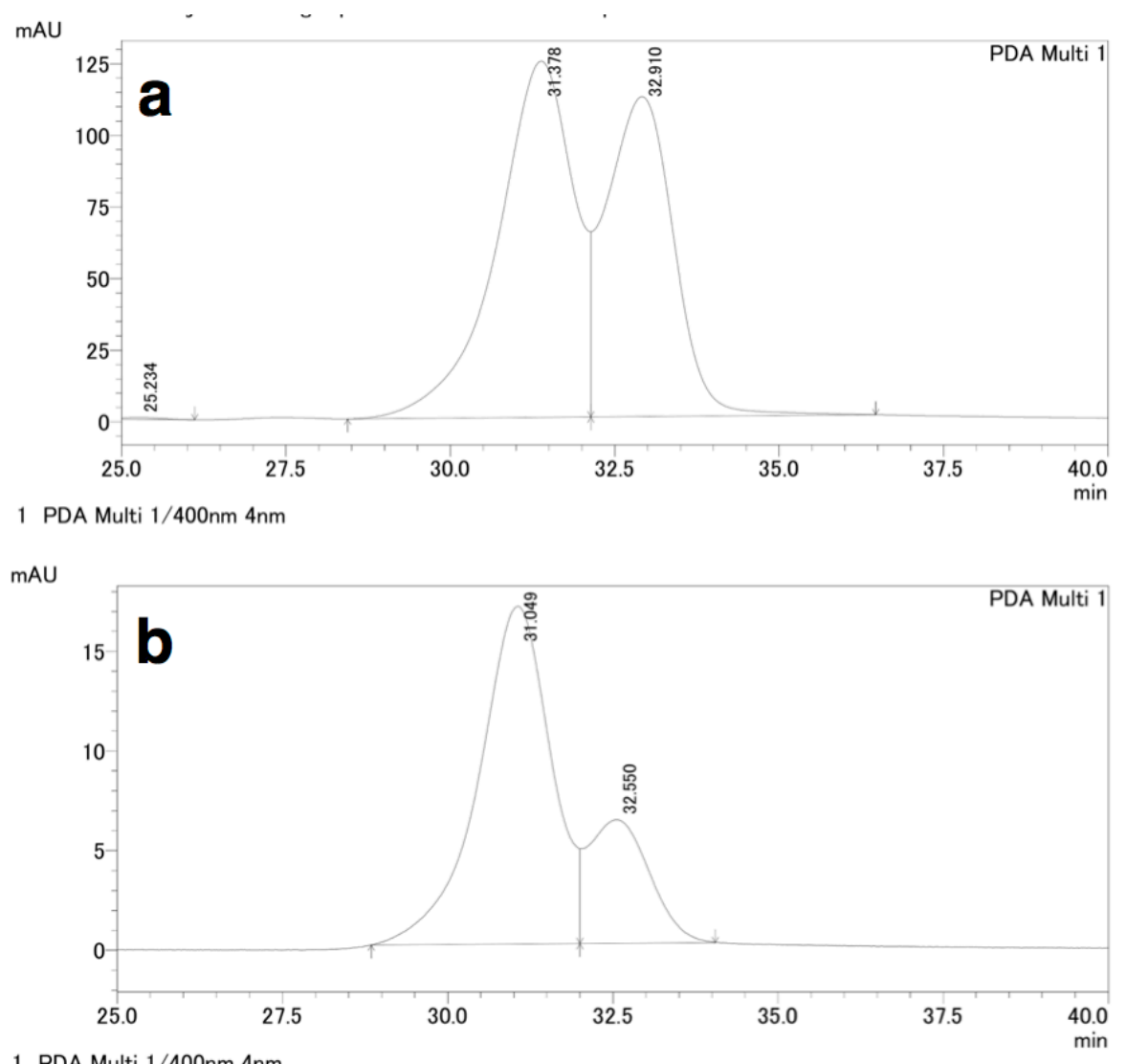

1 PDA Multi $1 / 400 \mathrm{~nm} 4 \mathrm{~nm}$

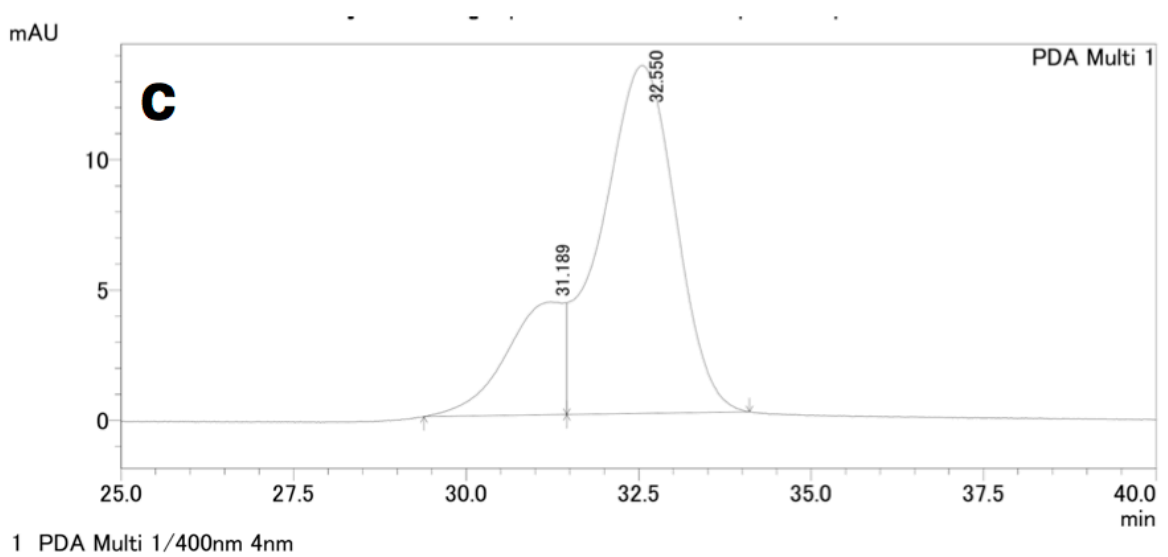

Figure S24. HPLC chart of $\mathbf{2 p}$ (a) before separation, (b) first fraction, and (c) second fraction. 


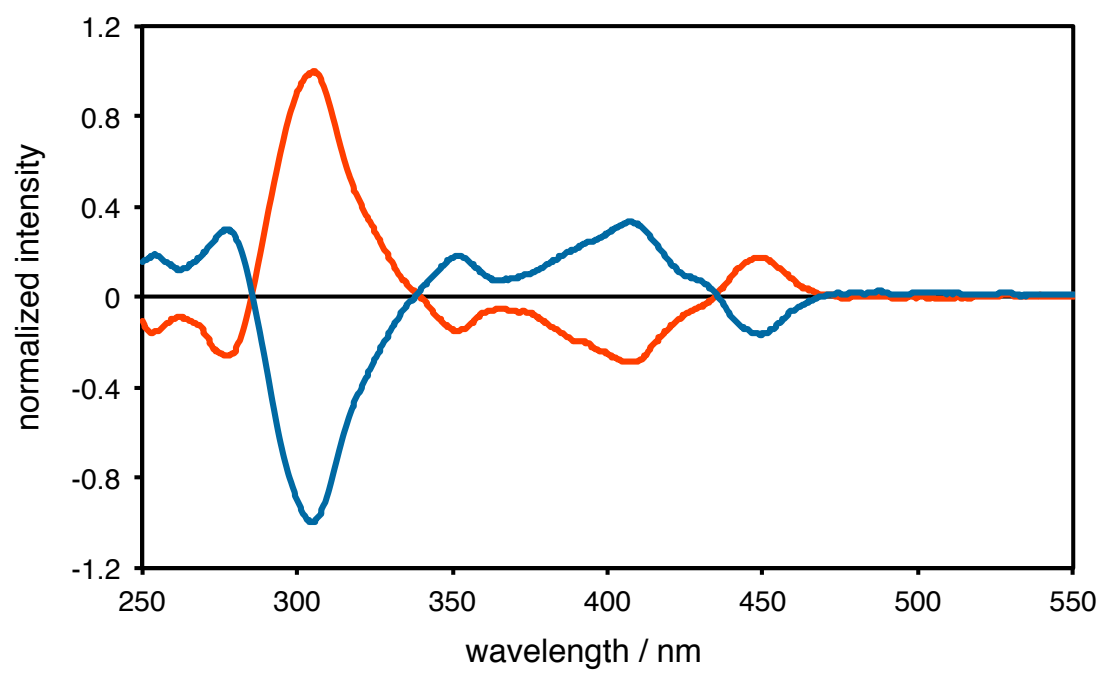

Figure S25. CD spectra of the 1,2-dichloroethane solution of the enantioenriched $\mathbf{2 p}$. The first fraction and the second fraction were shown as red and blue, respectively.

(a)

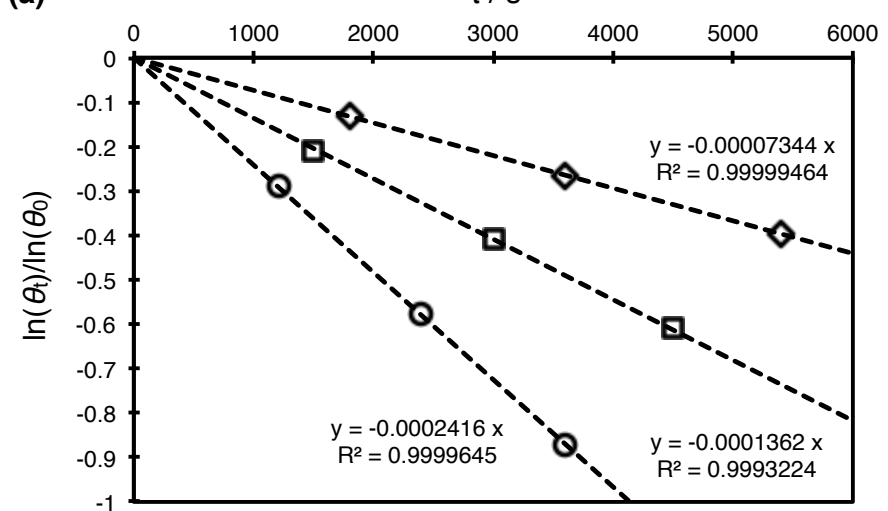

(b)

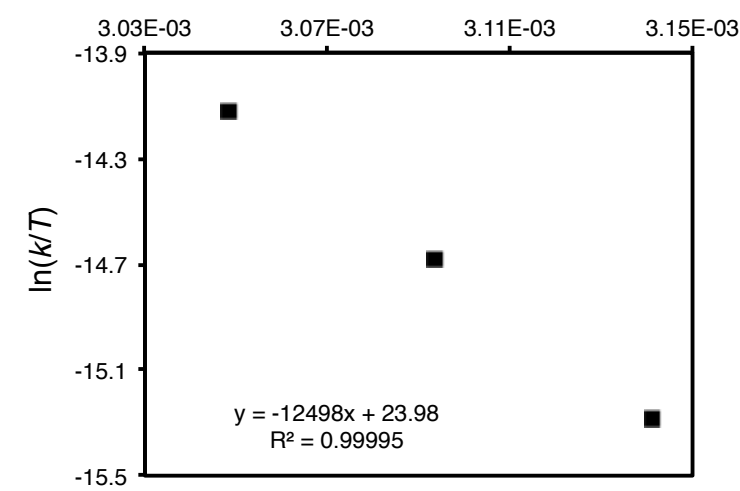

Figure S26. (a) Plots of the decreasing ellipticity at $306 \mathrm{~nm}$ in the CD spectra of enantio-enriched 2p in 1,2-dichloroethane upon heating at $164.5,173.5$, and $183.8^{\circ} \mathrm{C}$. (b) Eyring plot of the thermal racemization of 2 p. 


\section{Theoretical Study}

The Gaussian 09 program $^{17}$ running on a SGI Altix4700 system was used for optimization (B3LYP/6-31G(d)). ${ }^{18,19}$ All structures were optimized without any symmetry assumptions. Zero-point energy, enthalpy, and Gibbs free energy at $298.15 \mathrm{~K}$ and $1 \mathrm{~atm}$ were estimated from the gas-phase studies unless otherwise noted. Harmonic vibration frequency calculations at the same level were performed to verify all stationary points as local minima (with no imaginary frequency) or transition states (with one imaginary frequency). IRC calculations ${ }^{20,21}$ were also performed to check transition states. Visualization of the results was performed by use of Mercury CSD 3.8.
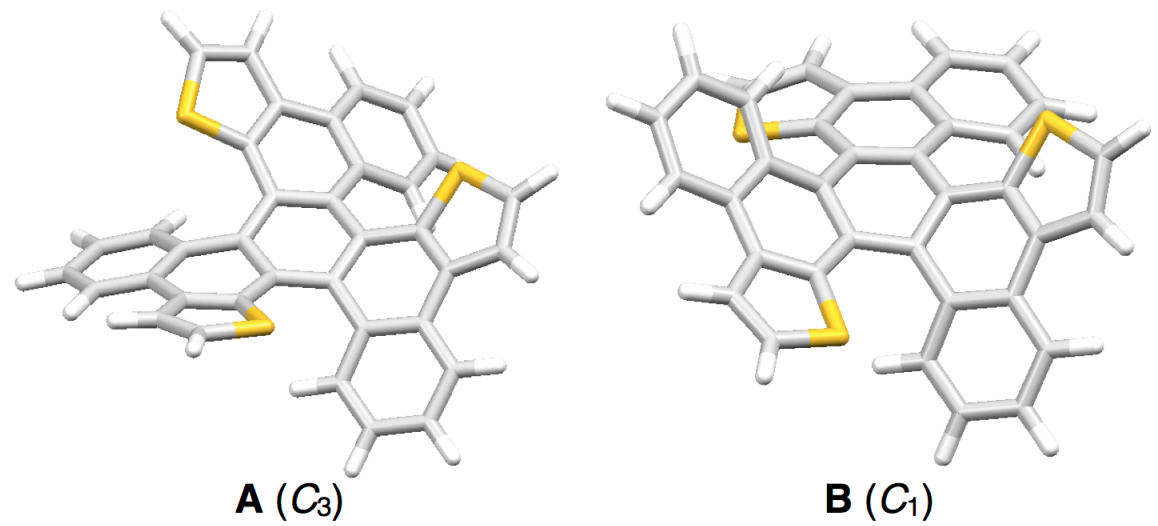

$\mathrm{B}\left(C_{1}\right)$

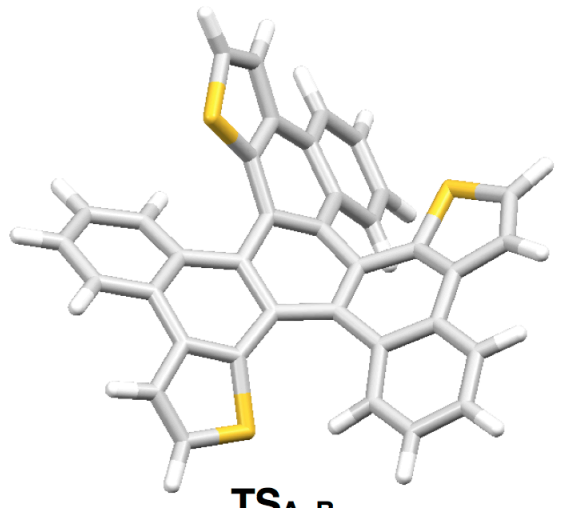

$\mathrm{TS}_{\mathrm{A}-\mathrm{B}}$

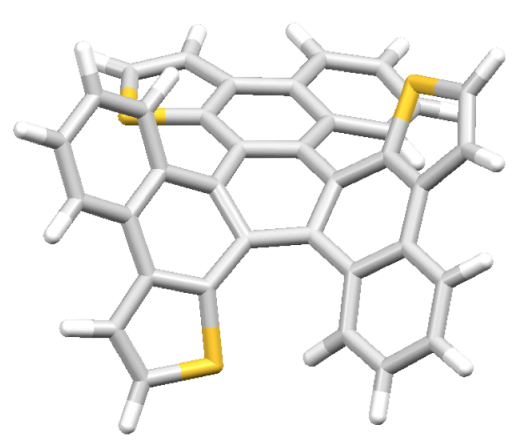

$\mathrm{TS}_{\mathrm{B}-\mathrm{B}^{*}}$

Figure S27. Optimized conformations of the simplified structures of $\mathbf{2 p}$.

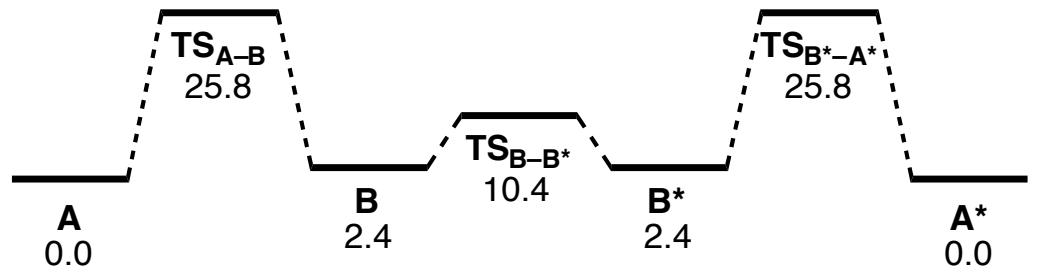

Figure S28. Isomerization pathway and relative energies $\left(\Delta G / \mathrm{kcal} \mathrm{mol}^{-1}\right)$ of the simplified structures of $\mathbf{2 p}$ calculated by B3LYP/6-31G(d) level. 


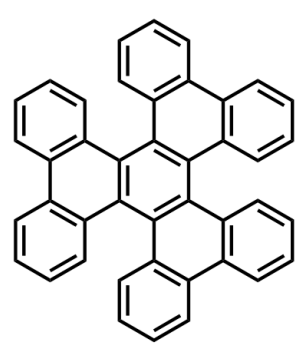

3

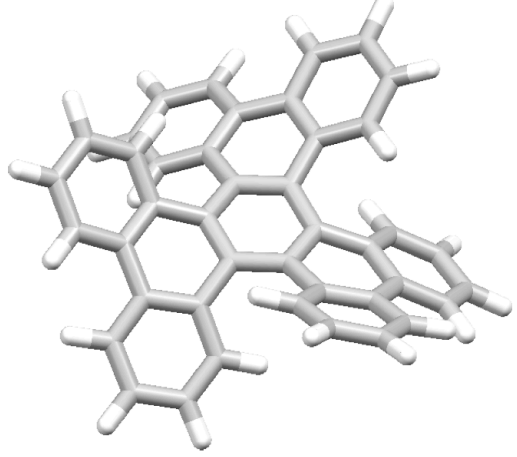

C $\left(D_{3}\right)$

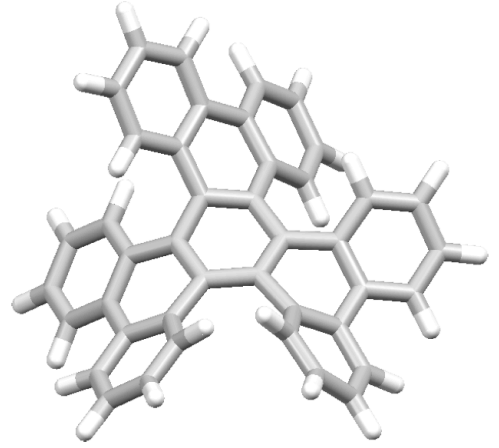

TSC-D
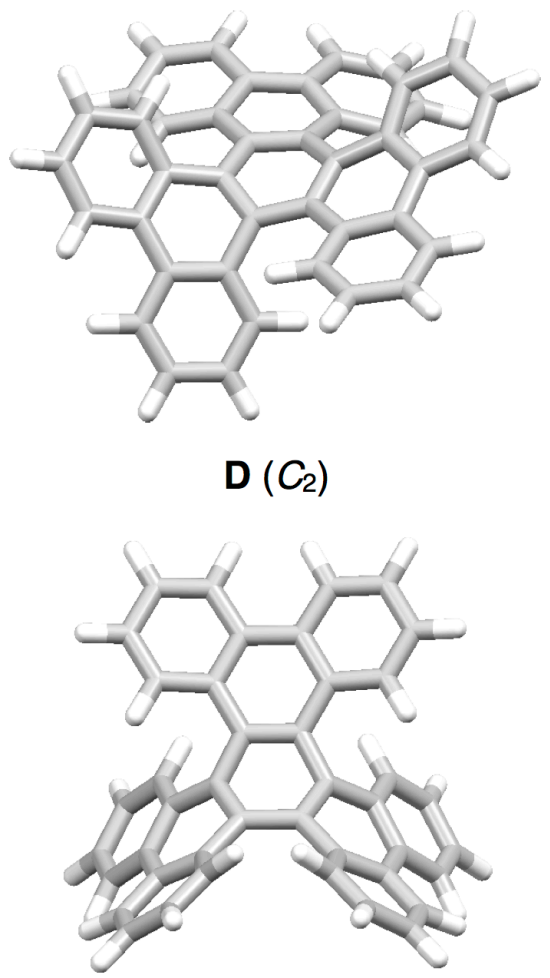

TS D-D*

Figure S29. Optimized conformations of the reference compound $\mathbf{3}$.

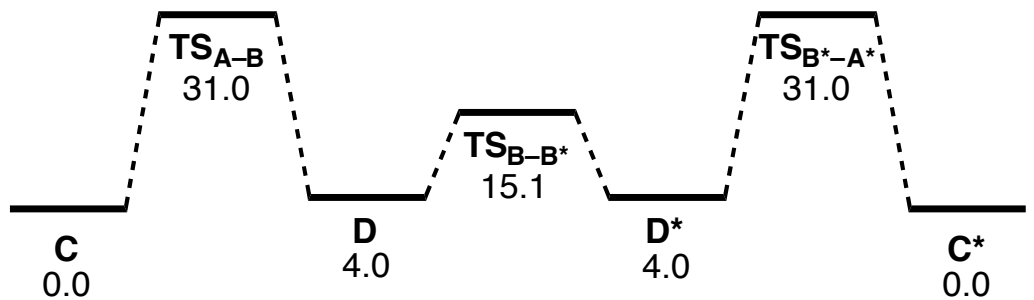

Figure S30. Isomerization pathway and relative energies $\left(\Delta G / \mathrm{kcal} \mathrm{mol}^{-1}\right)$ of the simplified structures of 3 calculated by B3LYP/6-31G(d) level.

Table S3. Uncorrected and thermal-corrected (298 K) energies of stationary points (Hartree). ${ }^{\mathrm{a}}$

\begin{tabular}{lllll}
\hline & $E$ & $E+Z P E$ & $H$ & $G$ \\
\hline $\mathbf{A}$ & -2577.27009996 & -2576.848539 & -2576.820147 & -2576.903627 \\
$\mathbf{B}$ & -2577.26502058 & -2576.843434 & -2576.815033 & -2576.899831 \\
$\mathbf{T S}_{\text {A-B }}$ & -2577.22754448 & -2576.806833 & -2576.779059 & -2576.862457 \\
$\mathbf{T S}_{\mathbf{B}-\mathbf{B}^{*}}$ & -2577.25308919 & -2576.831995 & -2576.804257 & -2576.887065 \\
$\mathbf{C}$ & -1614.98802351 & -1614.465120 & -1614.435932 & -1614.519952 \\
$\mathbf{D}$ & -1614.97911809 & -1614.456557 & -1614.427306 & -1614.513626 \\
$\mathbf{T S}_{\mathbf{C - D}}$ & -1614.93648015 & -1614.414664 & -1614.386091 & -1614.470613 \\
$\mathbf{T S}_{\mathbf{D - D}}$ & -1614.96189589 & -1614.439873 & -1614.411224 & -1614.495849
\end{tabular}

a) $E$ : electronic energy; $Z P E$ : zero-point energy; $H\left(=E+Z P E+E_{\mathrm{vib}}+E_{\mathrm{rot}}+E_{\text {trans }}+R T\right)$ : sum of electronic and thermal enthalpies; $G(=H-T S)$ : sum of electronic and thermal free energies. 
Table S4. Cartesian coordinates of optimized structures.

A

$\begin{array}{lrrr}\mathrm{C} & -1.229181 & 0.726377 & 0.226641 \\ \mathrm{C} & -2.432835 & 1.498291 & 0.538637 \\ \mathrm{C} & -3.504614 & 0.944561 & 1.279944 \\ \mathrm{H} & -3.442649 & -0.084516 & 1.613260 \\ \mathrm{C} & -4.609318 & 1.701528 & 1.628439 \\ \mathrm{H} & -5.407999 & 1.249886 & 2.210164 \\ \mathrm{C} & -4.689859 & 3.051705 & 1.249376 \\ \mathrm{H} & -5.560635 & 3.644133 & 1.516660 \\ \mathrm{C} & -3.632625 & 3.636863 & 0.576107 \\ \mathrm{H} & -3.663801 & 4.695967 & 0.337884 \\ \mathrm{C} & -2.483570 & 2.889995 & 0.241755 \\ \mathrm{C} & -1.318471 & 3.491956 & -0.354892 \\ \mathrm{C} & -1.230142 & 4.762520 & -1.012198 \\ \mathrm{H} & -2.067675 & 5.438957 & -1.137270 \\ \mathrm{~S} & 1.138571 & 3.735775 & -1.152061 \\ \mathrm{C} & -0.103054 & 2.803917 & -0.321126 \\ \mathrm{C} & 0.000000 & 1.421034 & 0.105270 \\ \mathrm{C} & 1.243651 & 0.701314 & 0.226641 \\ \mathrm{C} & 2.513976 & 1.357752 & 0.538637\end{array}$

$\begin{array}{lrrr}\mathrm{C} & 2.570321 & 2.562804 & 1.279944 \\ \mathrm{H} & 1.648131 & 3.023679 & 1.613260 \\ \mathrm{C} & 3.778225 & 3.141022 & 1.628439 \\ \mathrm{H} & 3.786433 & 4.058521 & 2.210164 \\ \mathrm{C} & 4.987784 & 2.535685 & 1.249376 \\ \mathrm{H} & 5.936229 & 2.993585 & 1.516660 \\ \mathrm{C} & 4.965928 & 1.327514 & 0.576107 \\ \mathrm{H} & 5.898727 & 0.824961 & 0.337884 \\ \mathrm{C} & 3.744594 & 0.705837 & 0.241755 \\ \mathrm{C} & 3.683358 & -0.604148 & -0.354892 \\ \mathrm{C} & 4.739534 & -1.315925 & -1.012198 \\ \mathrm{H} & 5.744112 & -0.928820 & -1.137270 \\ \mathrm{~S} & 2.665991 & -2.853919 & -1.152061 \\ \mathrm{C} & 2.479790 & -1.312711 & -0.321126 \\ \mathrm{C} & 1.230652 & -0.710517 & 0.105270 \\ \mathrm{C} & -0.014470 & -1.427690 & 0.226641 \\ \mathrm{C} & -0.081140 & -2.856043 & 0.538637 \\ \mathrm{C} & 0.934293 & -3.507365 & 1.279944 \\ \mathrm{H} & 1.794517 & -2.939163 & 1.613260\end{array}$

C $\quad 0.831092$

$-4.842550 \quad 1.628439$

$\begin{array}{llll}\mathrm{H} & 1.621566 & -5.308408 & 2.210164\end{array}$

$\begin{array}{llll}\text { C } & -0.297925 & -5.587390 & 1.249376\end{array}$

$\begin{array}{llll}\mathrm{H} & -0.375594 & -6.637718 & 1.516660\end{array}$

$\begin{array}{llll}\text { C } & -1.333303 & -4.964377 & 0.576107\end{array}$

$\begin{array}{llll}\mathrm{H} & -2.234926 & -5.520928 & 0.337884\end{array}$

$\begin{array}{llll}\text { C } & -1.261024 & -3.595832 & 0.241755\end{array}$

$\begin{array}{llll}\text { C } & -2.364887 & -2.887807 & -0.354892\end{array}$

$\begin{array}{llll}\text { C } & -3.509392 & -3.446594 & -1.012198\end{array}$

$\begin{array}{llll}\mathrm{C} & -3.509392 & -3.446594 & -1.012198 \\ \mathrm{H} & -3.676438 & -4.510137 & -1.137270\end{array}$

$\mathrm{S} \quad-3.804561 \quad-0.881856 \quad-1.152061$

$\begin{array}{llll}\text { C } & -2.376736 & -1.491206 & -0.321126\end{array}$

$\begin{array}{llll}\text { C } & -1.230652 & -0.710517 & 0.105270\end{array}$

$\begin{array}{llll}\text { C } & 0.014182 & 5.013804 & -1.501434\end{array}$

$\begin{array}{llll}\mathrm{H} & 0.352121 & 5.885349 & -2.046848\end{array}$

$\begin{array}{llll}\text { C } & -4.349173 & -2.494620 & -1.501434\end{array}$

$\begin{array}{llll}\mathrm{H} & -5.272922 & -2.637729 & -2.046848\end{array}$

$\begin{array}{lllll}\text { C } & 4.334990 & -2.519184 & -1.501434\end{array}$

$\begin{array}{llll}\mathrm{H} & 4.920801 & -3.247620 & -2.046848\end{array}$

\section{B}

$\begin{array}{lrrr}\mathrm{C} & 0.583180 & -1.345488 & 0.045365 \\ \mathrm{C} & 1.085023 & -2.700178 & -0.173215 \\ \mathrm{C} & 0.241539 & -3.837069 & -0.285031 \\ \mathrm{C} & 0.747482 & -5.111864 & -0.446096 \\ \mathrm{C} & 2.135861 & -5.320181 & -0.524579 \\ \mathrm{C} & 2.980456 & -4.229930 & -0.529091 \\ \mathrm{C} & 2.480075 & -2.912072 & -0.403569 \\ \mathrm{C} & 3.318352 & -1.771866 & -0.653835 \\ \mathrm{C} & 4.654382 & -1.781017 & -1.184179 \\ \mathrm{~S} & 3.913300 & 0.698005 & -1.214025 \\ \mathrm{C} & 2.783613 & -0.483943 & -0.560687 \\ \mathrm{C} & 1.440436 & -0.234823 & -0.117936 \\ \mathrm{C} & 0.900940 & 1.103014 & 0.079164 \\ \mathrm{C} & 1.701143 & 2.170308 & 0.648875 \\ \mathrm{C} & 2.884386 & 1.915239 & 1.393763 \\ \mathrm{C} & 3.631876 & 2.939369 & 1.937357 \\ \mathrm{C} & 3.231870 & 4.277692 & 1.760900 \\ \mathrm{C} & 2.044184 & 4.554359 & 1.115847 \\ \mathrm{C} & 1.237191 & 3.515199 & 0.592752\end{array}$

$\begin{array}{lrrr}\mathrm{C} & -0.102220 & 3.752361 & 0.131155 \\ \mathrm{C} & -0.783286 & 5.016263 & 0.151040 \\ \mathrm{~S} & -2.597034 & 3.261415 & -0.391635 \\ \mathrm{C} & -0.941961 & 2.676834 & -0.200463 \\ \mathrm{C} & -0.465034 & 1.311280 & -0.242067 \\ \mathrm{C} & -1.327410 & 0.140708 & -0.325632 \\ \mathrm{C} & -2.695028 & 0.115455 & -0.829437 \\ \mathrm{C} & -3.073156 & 0.848826 & -1.977906 \\ \mathrm{C} & -4.352630 & 0.756510 & -2.499869 \\ \mathrm{C} & -5.308399 & -0.070067 & -1.886354 \\ \mathrm{C} & -4.949930 & -0.844660 & -0.796246 \\ \mathrm{C} & -3.640801 & -0.799232 & -0.275421 \\ \mathrm{C} & -3.181243 & -1.683360 & 0.765982 \\ \mathrm{C} & -3.953096 & -2.459850 & 1.690309 \\ \mathrm{~S} & -1.476389 & -2.961428 & 2.259811 \\ \mathrm{C} & -1.803375 & -1.864039 & 0.925091 \\ \mathrm{C} & -0.831357 & -1.061042 & 0.231121 \\ \mathrm{H} & -0.830722 & -3.709239 & -0.271942 \\ \mathrm{H} & 0.063929 & -5.952910 & -0.522166\end{array}$

$\begin{array}{lrrr}\mathrm{H} & 2.537140 & -6.324968 & -0.624393 \\ \mathrm{H} & 4.048170 & -4.378683 & -0.655444 \\ \mathrm{H} & 5.246533 & -2.676526 & -1.328816 \\ \mathrm{H} & 3.190156 & 0.890644 & 1.564746 \\ \mathrm{H} & 4.526008 & 2.708455 & 2.509619 \\ \mathrm{H} & 3.832603 & 5.086580 & 2.167735 \\ \mathrm{H} & 1.704863 & 5.582204 & 1.040057 \\ \mathrm{H} & -0.300069 & 5.962228 & 0.362621 \\ \mathrm{H} & -2.331086 & 1.456525 & -2.483877 \\ \mathrm{H} & -4.609866 & 1.315504 & -3.395188 \\ \mathrm{H} & -6.314866 & -0.133494 & -2.290800 \\ \mathrm{H} & -5.668620 & -1.534365 & -0.362834 \\ \mathrm{H} & -5.036552 & -2.456986 & 1.726814 \\ \mathrm{C} & -3.178722 & -3.175890 & 2.552054 \\ \mathrm{H} & -3.502471 & -3.819875 & 3.359173 \\ \mathrm{C} & -2.112449 & 4.902030 & -0.096460 \\ \mathrm{H} & -2.853066 & 5.690231 & -0.139056 \\ \mathrm{C} & 5.087982 & -0.542342 & -1.537417 \\ \mathrm{H} & 6.040635 & -0.272396 & -1.974383\end{array}$

$\mathbf{T S}_{\mathrm{A}-\mathrm{B}}$

$\begin{array}{lccc}\mathrm{C} & -0.860992 & -1.097214 & 0.089700 \\ \mathrm{C} & -1.563267 & -2.380665 & 0.038147 \\ \mathrm{C} & -0.950222 & -3.622896 & 0.345434 \\ \mathrm{H} & 0.054393 & -3.637662 & 0.745863 \\ \mathrm{C} & -1.615060 & -4.822511 & 0.174351 \\ \mathrm{H} & -1.114180 & -5.754148 & 0.421662 \\ \mathrm{C} & -2.932272 & -4.835181 & -0.315987 \\ \mathrm{H} & -3.442886 & -5.777061 & -0.497139 \\ \mathrm{C} & -3.599116 & -3.638726 & -0.489785 \\ \mathrm{H} & -4.646098 & -3.645134 & -0.774257 \\ \mathrm{C} & -2.950629 & -2.406821 & -0.238710 \\ \mathrm{C} & -3.675969 & -1.192892 & 0.015788 \\ \mathrm{C} & -5.096652 & -1.171424 & 0.211639 \\ \mathrm{H} & -5.757996 & -1.973321 & -0.090858 \\ \mathrm{~S} & -4.212458 & 0.983907 & 1.260803 \\ \mathrm{C} & -3.010356 & -0.023749 & 0.434083\end{array}$

$\begin{array}{lrrr}\mathrm{C} & -2.492516 & 3.288400 & 0.323675 \\ \mathrm{H} & -3.110410 & 2.741082 & 1.001187 \\ \mathrm{C} & -2.962968 & 4.529500 & -0.068167 \\ \mathrm{H} & -3.947374 & 4.850567 & 0.261447 \\ \mathrm{C} & -2.164473 & 5.367595 & -0.853948 \\ \mathrm{H} & -2.525987 & 6.335744 & -1.189034 \\ \mathrm{C} & -0.873547 & 4.964729 & -1.127318 \\ \mathrm{H} & -0.204400 & 5.639454 & -1.650502 \\ \mathrm{C} & -0.375083 & 3.715913 & -0.692701 \\ \mathrm{C} & 1.022752 & 3.428338 & -0.820483 \\ \mathrm{C} & 2.019776 & 4.203625 & -1.502234 \\ \mathrm{H} & 1.818141 & 5.119252 & -2.044330 \\ \mathrm{~S} & 3.273171 & 2.192787 & -0.471083 \\ \mathrm{C} & 1.530097 & 2.295587 & -0.193851 \\ \mathrm{C} & 0.665758 & 1.250019 & 0.318093 \\ \mathrm{C} & 1.281105 & -0.035830 & 0.542689\end{array}$

$\begin{array}{lrrr}\mathrm{C} & 4.319061 & 0.360070 & 2.731355 \\ \mathrm{H} & 4.677808 & 1.014113 & 3.521013 \\ \mathrm{C} & 5.083757 & -0.751324 & 2.335980 \\ \mathrm{H} & 6.039588 & -0.950356 & 2.812957 \\ \mathrm{C} & 4.607851 & -1.610119 & 1.358680 \\ \mathrm{H} & 5.185441 & -2.487278 & 1.081094 \\ \mathrm{C} & 3.360700 & -1.381797 & 0.744321 \\ \mathrm{C} & 2.797387 & -2.245382 & -0.264803 \\ \mathrm{C} & 3.483648 & -3.199389 & -1.086173 \\ \mathrm{H} & 4.543470 & -3.412796 & -1.007018 \\ \mathrm{~S} & 1.030760 & -3.205856 & -1.907441 \\ \mathrm{C} & 1.433824 & -2.151615 & -0.559912 \\ \mathrm{C} & 0.583134 & -1.133256 & 0.028141 \\ \mathrm{C} & 3.259429 & 3.658619 & -1.401836 \\ \mathrm{H} & 4.188394 & 4.041178 & -1.804871 \\ \mathrm{C} & 2.672046 & -3.770440 & -2.017477\end{array}$




\begin{tabular}{|c|c|c|c|c|c|c|c|c|c|c|c|}
\hline $\mathrm{C}$ & -1.555681 & 0.141803 & 0.308960 & $\mathrm{C}$ & 2.603029 & -0.232600 & 1.109371 & $\mathrm{H}$ & 2.935502 & -4.494439 & -2.777404 \\
\hline $\mathrm{C}$ & -0.749857 & 1.395267 & 0.250512 & $\mathrm{C}$ & 3.101700 & 0.616471 & 2.125072 & $\mathrm{C}$ & -5.519438 & -0.079110 & 0.892438 \\
\hline $\mathrm{C}$ & -1.233044 & 2.769125 & -0.040354 & $\mathrm{H}$ & 2.503101 & 1.463727 & 2.444849 & $\mathrm{H}$ & -6.523543 & 0.180939 & 1.200756 \\
\hline \multicolumn{12}{|c|}{$\mathbf{T S}_{\mathbf{B}-\mathrm{B}^{*}}$} \\
\hline $\mathrm{C}$ & -1.442316 & -0.130765 & -0.231611 & $\mathrm{C}$ & 3.572122 & -1.011373 & -0.184879 & $\mathrm{H}$ & -6.477794 & -0.798231 & -1.968467 \\
\hline $\mathrm{C}$ & -2.804319 & -0.292752 & -0.702484 & $\mathrm{C}$ & 4.869057 & -1.129823 & -0.778420 & $\mathrm{H}$ & -5.130007 & -2.746999 & -1.309254 \\
\hline $\mathrm{C}$ & -3.584191 & 0.798093 & -1.170482 & $S$ & 3.676525 & 0.737351 & -2.075283 & $\mathrm{H}$ & -3.817994 & -4.474044 & -1.080253 \\
\hline C & -4.877395 & 0.622555 & -1.618708 & $\mathrm{C}$ & 2.780219 & 0.009232 & -0.739863 & $\mathrm{H}$ & 0.010085 & -2.595159 & 2.239795 \\
\hline $\mathrm{C}$ & -5.454040 & -0.661651 & -1.630930 & $\mathrm{C}$ & 1.374644 & 0.182190 & -0.384184 & $\mathrm{H}$ & 1.438770 & -3.953245 & 3.705264 \\
\hline $\mathrm{C}$ & -4.699088 & -1.752535 & -1.251767 & $\mathrm{C}$ & 0.509912 & 1.383201 & -0.357354 & $\mathrm{H}$ & 3.908003 & -4.010291 & 3.350586 \\
\hline $\mathrm{C}$ & -3.361341 & -1.601930 & -0.814851 & $\mathrm{C}$ & 0.962059 & 2.785538 & -0.387768 & $\mathrm{H}$ & 4.925609 & -2.632478 & 1.573937 \\
\hline $\mathrm{C}$ & -2.506734 & -2.735541 & -0.585079 & $\mathrm{C}$ & 2.038865 & 3.257406 & -1.168625 & $\mathrm{H}$ & 5.607680 & -1.857982 & -0.464376 \\
\hline $\mathrm{C}$ & -2.829967 & -4.116622 & -0.816318 & $\mathrm{C}$ & 2.475284 & 4.570130 & -1.139220 & $\mathrm{H}$ & 2.510500 & 2.599082 & -1.873213 \\
\hline S & -0.300895 & -4.081383 & -0.274167 & $\mathrm{C}$ & 1.839207 & 5.507873 & -0.314179 & $\mathrm{H}$ & 3.301911 & 4.869888 & -1.777493 \\
\hline $\mathrm{C}$ & -1.162061 & -2.546733 & -0.241252 & $\mathrm{C}$ & 0.733031 & 5.111694 & 0.410034 & $\mathrm{H}$ & 2.182307 & 6.538024 & -0.276771 \\
\hline $\mathrm{C}$ & -0.602127 & -1.237113 & -0.034992 & $\mathrm{C}$ & 0.256857 & 3.782320 & 0.366718 & $\mathrm{H}$ & 0.188687 & 5.841763 & 1.000822 \\
\hline $\mathrm{C}$ & 0.809267 & -0.991243 & 0.192630 & $\mathrm{C}$ & -0.956012 & 3.421738 & 1.043827 & $\mathrm{H}$ & -1.440674 & 5.172780 & 2.342035 \\
\hline $\mathrm{C}$ & 1.630710 & -1.874388 & 0.997404 & $\mathrm{C}$ & -1.714420 & 4.184039 & 1.993366 & $\mathrm{C}$ & -2.815573 & 3.519785 & 2.437929 \\
\hline $\mathrm{C}$ & 1.077587 & -2.638676 & 2.055835 & $\mathrm{~S}$ & -2.993977 & 1.949099 & 1.711559 & $\mathrm{H}$ & -3.550413 & 3.860453 & 3.155762 \\
\hline $\mathrm{C}$ & 1.884129 & -3.391836 & 2.888739 & $\mathrm{C}$ & -1.524161 & 2.179268 & 0.767539 & $\mathrm{C}$ & -1.753849 & -4.937227 & -0.697757 \\
\hline $\mathrm{C}$ & 3.277113 & -3.416117 & 2.695187 & $\mathrm{C}$ & -0.844512 & 1.169569 & 0.013759 & $\mathrm{H}$ & -1.721152 & -6.011865 & -0.822051 \\
\hline $\mathrm{C}$ & 3.846273 & -2.651994 & 1.692263 & $\mathrm{H}$ & -3.147381 & 1.788692 & -1.194764 & $\mathrm{C}$ & 5.057641 & -0.273059 & -1.815400 \\
\hline $\mathrm{C}$ & 3.042423 & -1.857664 & 0.848779 & $\mathrm{H}$ & -5.446064 & 1.478685 & -1.970746 & $\mathrm{H}$ & 5.925709 & -0.163682 & -2.451877 \\
\hline \multicolumn{12}{|l|}{ C } \\
\hline $\mathrm{C}$ & 0.702656 & 1.233039 & 0.061899 & $\mathrm{C}$ & -3.426839 & 0.953984 & 1.236133 & $\mathrm{H}$ & -1.137820 & -5.268646 & -2.329677 \\
\hline $\mathrm{C}$ & -0.702656 & 1.233039 & -0.061899 & $\mathrm{C}$ & -4.703957 & 0.831256 & 1.756080 & $\mathrm{H}$ & 0.178087 & -3.413907 & -1.426457 \\
\hline $\mathrm{C}$ & -1.419171 & -0.008001 & 0.061899 & $\mathrm{C}$ & -5.427126 & -0.355227 & 1.568590 & $\mathrm{H}$ & -2.867487 & 1.861182 & 1.426457 \\
\hline $\mathrm{C}$ & -0.716515 & -1.225038 & -0.061899 & $\mathrm{C}$ & -4.844279 & -1.407599 & 0.883436 & $\mathrm{H}$ & -5.131691 & 1.648942 & 2.329677 \\
\hline $\mathrm{C}$ & 0.716515 & -1.225038 & 0.061899 & $\mathrm{C}$ & -1.203123 & 4.899068 & -0.883436 & $\mathrm{H}$ & -6.425388 & -0.462316 & 1.984080 \\
\hline $\mathrm{C}$ & 1.419171 & -0.008001 & -0.061899 & $\mathrm{C}$ & -2.405927 & 4.877642 & -1.568590 & $\mathrm{H}$ & -5.385331 & -2.343781 & 0.793344 \\
\hline $\mathrm{C}$ & 1.334112 & 2.491077 & 0.495539 & $\mathrm{C}$ & -3.071868 & 3.658118 & -1.756080 & $\mathrm{H}$ & -0.662892 & 5.835724 & -0.793344 \\
\hline $\mathrm{C}$ & 0.642353 & 3.722004 & 0.345848 & $\mathrm{C}$ & -2.539594 & 2.490738 & -1.236133 & $\mathrm{H}$ & -2.812317 & 5.795707 & -1.984080 \\
\hline $\mathrm{C}$ & -0.642353 & 3.722004 & -0.345848 & $\mathrm{C}$ & 2.539594 & 2.490738 & 1.236133 & $\mathrm{H}$ & -3.993871 & 3.619704 & -2.329677 \\
\hline $\mathrm{C}$ & -1.334112 & 2.491077 & -0.495539 & $\mathrm{C}$ & 3.071868 & 3.658118 & 1.756080 & $\mathrm{H}$ & -3.045574 & 1.552725 & -1.426457 \\
\hline $\mathrm{C}$ & 1.490280 & -2.400914 & 0.495539 & $\mathrm{C}$ & 2.405927 & 4.877642 & 1.568590 & $\mathrm{H}$ & 3.045574 & 1.552725 & 1.426457 \\
\hline $\mathrm{C}$ & 2.902174 & -2.417296 & 0.345848 & $\mathrm{C}$ & 1.203123 & 4.899068 & 0.883436 & $\mathrm{H}$ & 3.993871 & 3.619704 & 2.329677 \\
\hline $\mathrm{C}$ & 3.544527 & -1.304708 & -0.345848 & $\mathrm{C}$ & 4.844279 & -1.407599 & -0.883436 & $\mathrm{H}$ & 2.812317 & 5.795707 & 1.984080 \\
\hline $\mathrm{C}$ & 2.824393 & -0.090163 & -0.495539 & $\mathrm{C}$ & 5.427126 & -0.355227 & -1.568590 & $\mathrm{H}$ & 0.662892 & 5.835724 & 0.793344 \\
\hline $\mathrm{C}$ & -2.824393 & -0.090163 & 0.495539 & $\mathrm{C}$ & 4.703957 & 0.831256 & -1.756080 & $\mathrm{H}$ & 5.385331 & -2.343781 & -0.793344 \\
\hline $\mathrm{C}$ & -3.544527 & -1.304708 & 0.345848 & $\mathrm{C}$ & 3.426839 & 0.953984 & -1.236133 & $\mathrm{H}$ & 6.425388 & -0.462316 & -1.984080 \\
\hline $\mathrm{C}$ & -2.902174 & -2.417296 & -0.345848 & $\mathrm{C}$ & 0.887246 & -3.444722 & 1.236133 & $\mathrm{H}$ & 5.131691 & 1.648942 & -2.329677 \\
\hline $\mathrm{C}$ & -1.490280 & -2.400914 & -0.495539 & $\mathrm{C}$ & 1.632090 & -4.489375 & 1.756080 & $\mathrm{H}$ & 2.867487 & 1.861182 & -1.426457 \\
\hline $\mathrm{C}$ & -3.641156 & -3.491469 & -0.883436 & $\mathrm{C}$ & 3.021199 & -4.522415 & 1.568590 & $\mathrm{H}$ & -0.178087 & -3.413907 & 1.426457 \\
\hline $\mathrm{C}$ & -3.021199 & -4.522415 & -1.568590 & $\mathrm{C}$ & 3.641156 & -3.491469 & 0.883436 & $\mathrm{H}$ & 1.137820 & -5.268646 & 2.329677 \\
\hline $\mathrm{C}$ & -1.632090 & -4.489375 & -1.756080 & $\mathrm{H}$ & -4.722439 & -3.491943 & -0.793344 & $\mathrm{H}$ & 3.613071 & -5.333391 & 1.984080 \\
\hline $\mathrm{C}$ & -0.887246 & -3.444722 & -1.236133 & $\mathrm{H}$ & -3.613071 & -5.333391 & -1.984080 & $\mathrm{H}$ & 4.722439 & -3.491943 & 0.793344 \\
\hline \multicolumn{12}{|l|}{ D } \\
\hline $\mathrm{C}$ & 0.016132 & 1.430727 & 0.048585 & $\mathrm{C}$ & 3.444993 & -0.717474 & 1.289795 & $\mathrm{H}$ & -2.051199 & -5.613728 & 0.283760 \\
\hline $\mathrm{C}$ & 1.213830 & 0.710665 & -0.134485 & $\mathrm{C}$ & 4.582813 & -1.369434 & 1.724077 & $\mathrm{H}$ & -2.112374 & -3.181374 & 0.271755 \\
\hline $\mathrm{C}$ & 1.212028 & -0.713807 & 0.133948 & $\mathrm{C}$ & 4.711731 & -2.753108 & 1.523846 & $\mathrm{H}$ & 3.349692 & 0.347965 & 1.457360 \\
\hline $\mathrm{C}$ & 0.012465 & -1.430760 & -0.048858 & $\mathrm{C}$ & 3.664850 & -3.463626 & 0.967162 & $\mathrm{H}$ & 5.369277 & -0.810962 & 2.224045 \\
\hline $\mathrm{C}$ & -1.202884 & -0.666334 & -0.225056 & $\mathrm{C}$ & 3.674105 & 3.454089 & -0.966621 & $\mathrm{H}$ & 5.609714 & -3.273626 & 1.845493 \\
\hline $\mathrm{C}$ & -1.201144 & 0.669411 & 0.224826 & $\mathrm{C}$ & 4.719002 & 2.740923 & -1.523658 & $\mathrm{H}$ & 3.751614 & -4.541659 & 0.897496 \\
\hline $\mathrm{C}$ & 0.033304 & 2.894284 & -0.103134 & $\mathrm{C}$ & 4.586238 & 1.357719 & -1.724630 & $\mathrm{H}$ & 3.763924 & 4.531837 & -0.896321 \\
\hline $\mathrm{C}$ & 1.280220 & 3.577143 & -0.212480 & $\mathrm{C}$ & 3.446641 & 0.708690 & -1.290598 & $\mathrm{H}$ & 5.618456 & 3.259102 & -1.844979 \\
\hline $\mathrm{C}$ & 2.479350 & 2.818135 & -0.553839 & $\mathrm{C}$ & -1.143719 & 3.676146 & -0.201726 & $\mathrm{H}$ & 5.371144 & 0.797376 & -2.224950 \\
\hline $\mathrm{C}$ & 2.397736 & 1.403382 & -0.639834 & $\mathrm{C}$ & -1.108096 & 5.058563 & -0.214761 & $\mathrm{H}$ & 3.348310 & -0.356395 & -1.458648 \\
\hline G & -2.444361 & -1.115963 & -0.864911 & $\mathrm{C}$ & 0.122375 & 5.726297 & -0.137507 & $\mathrm{H}$ & -2.103918 & 3.187354 & -0.271479 \\
\hline
\end{tabular}




$\begin{array}{lrrr}\text { C } & -3.677121 & -0.493464 & -0.533189 \\ \text { C } & -3.675844 & 0.502938 & 0.532859 \\ \text { C } & -2.441498 & 1.122157 & 0.864733 \\ \text { C } & 2.394144 & -1.409538 & 0.639380 \\ \text { C } & 2.471883 & -2.824557 & 0.553976 \\ \text { C } & 1.270725 & -3.580476 & 0.212815 \\ \text { C } & 0.025666 & -2.894274 & 0.103361 \\ \text { C } & 1.278231 & -4.993367 & 0.162277 \\ \text { C } & 0.106962 & -5.726455 & 0.138199 \\ \text { C } & -1.121688 & -5.055345 & 0.215446 \\ \text { C } & -1.153522 & -3.672856 & 0.202158 \\ \text { TS } & & & \\ \text { C } & 1.302363 & 0.624607 & 0.476514 \\ \text { C } & 0.117769 & 1.376090 & 0.216968 \\ \text { C } & -1.159061 & 0.722226 & 0.158233 \\ \text { C } & -1.212080 & -0.643856 & 0.465241 \\ \text { C } & -0.040751 & -1.419773 & 0.170970 \\ \text { C } & 1.235331 & -0.837548 & 0.365687 \\ \text { C } & 2.551934 & 1.422574 & 0.557577 \\ \text { C } & 2.652693 & 2.612039 & -0.228162 \\ \text { C } & 1.425775 & 3.377051 & -0.454966 \\ \text { C } & 0.219589 & 2.835421 & 0.055257 \\ \text { C } & -0.198283 & -2.648569 & -0.633138 \\ \text { C } & 0.957963 & -3.303489 & -1.126742 \\ \text { C } & 2.243271 & -2.967706 & -0.528343 \\ \text { C } & 2.361376 & -1.812673 & 0.303211 \\ \text { C } & -2.438490 & 1.280712 & -0.334456 \\ \text { C } & -3.666585 & 0.716308 & 0.106009 \\ \text { C } & -3.632532 & -0.434963 & 1.004882 \\ \text { C } & -2.428808 & -1.183897 & 1.064141 \\ \text { C } & -4.742951 & -0.867825 & 1.754436 \\ \text { C } & -4.681489 & -2.017536 & 2.527803 \\ \text { C } & -3.495692 & -2.766072 & 2.576772 \\ \text { C } & -2.385258 & -2.349193 & 1.861438 \\ & & & \end{array}$

$\begin{array}{lrrr}\mathrm{C} & 1.291615 & 4.989982 & -0.161775 \\ \mathrm{C} & -4.837108 & 0.857855 & 1.247508 \\ \mathrm{C} & -4.789637 & 1.777128 & 2.283361 \\ \mathrm{C} & -3.563607 & 2.357419 & 2.642373 \\ \mathrm{C} & -2.411904 & 2.032682 & 1.945237 \\ \mathrm{C} & -2.417165 & -2.026769 & -1.945254 \\ \mathrm{C} & -3.569696 & -2.348528 & -2.642397 \\ \mathrm{C} & -4.794201 & -1.764919 & -2.283563 \\ \mathrm{C} & -4.839283 & -0.845382 & -1.247837 \\ \mathrm{H} & 2.223346 & -5.524312 & 0.168598 \\ \mathrm{H} & 0.143539 & -6.811922 & 0.105141\end{array}$

$\begin{array}{cc}\mathrm{H} & -2.036088 \\ \mathrm{H} & 0.161961 \\ \mathrm{H} & 2.238202 \\ \mathrm{H} & -5.778308 \\ \mathrm{H} & -5.694271 \\ \mathrm{H} & -3.510074 \\ \mathrm{H} & -1.463633 \\ \mathrm{H} & -1.470057 \\ \mathrm{H} & -3.517967 \\ \mathrm{H} & -5.699445 \\ \mathrm{H} & -5.779197\end{array}$

$\begin{array}{cc}5.619481 & -0.282951 \\ 6.811655 & -0.104373 \\ 5.518307 & -0.168252 \\ 0.372518 & 1.008414 \\ 2.025012 & 2.831758 \\ 3.049095 & 3.478601 \\ 2.466915 & 2.242046 \\ -2.463550 & -2.242016 \\ -3.040494 & -3.478502 \\ -2.010461 & -2.832006 \\ -0.357518 & -1.008833\end{array}$

$\begin{array}{rrrr}\mathrm{C} & -2.485281 & 2.226513 & -1.383206 \\ \mathrm{C} & -3.688902 & 2.677900 & -1.900216 \\ \mathrm{C} & -4.900471 & 2.192943 & -1.389309 \\ \mathrm{C} & -4.880864 & 1.211781 & -0.412277 \\ \mathrm{C} & 1.446447 & 4.728134 & -0.862288 \\ \mathrm{C} & 0.362113 & 5.560825 & -0.636565 \\ \mathrm{C} & -0.753927 & 5.071481 & 0.056503 \\ \mathrm{C} & -0.818859 & 3.728582 & 0.392746 \\ \mathrm{C} & 4.876223 & 1.798334 & 1.249404 \\ \mathrm{C} & 5.043331 & 2.742934 & 0.232268 \\ \mathrm{C} & 3.922796 & 3.178319 & -0.457889 \\ \mathrm{C} & 3.334535 & -3.851354 & -0.661013 \\ \mathrm{C} & 4.505090 & -3.687783 & 0.058337 \\ \mathrm{C} & 4.567117 & -2.658825 & 0.998281 \\ \mathrm{C} & -1.453511 & -3.058283 & -1.148499 \\ \mathrm{C} & -1.564107 & -4.064751 & -2.091584 \\ \mathrm{C} & -0.413660 & -4.686162 & -2.594161 \\ \mathrm{C} & 0.825759 & -4.297281 & -2.119587 \\ \mathrm{H} & -5.657191 & -0.282614 & 1.744282 \\ \mathrm{H} & -5.547678 & -2.328469 & 3.105463 \\ \mathrm{H} & -3.438057 & -3.658822 & 3.193286 \\ \mathrm{H} & -1.456188 & -2.905583 & 1.930679\end{array}$

$\begin{array}{cc}\mathrm{H} & -1.560106 \\ \mathrm{H} & -3.686190 \\ \mathrm{H} & -5.847317 \\ \mathrm{H} & -5.817058 \\ \mathrm{H} & 2.347800 \\ \mathrm{H} & 0.407522 \\ \mathrm{H} & -1.568878 \\ \mathrm{H} & -1.689209 \\ \mathrm{H} & 5.693733 \\ \mathrm{H} & 6.011386 \\ \mathrm{H} & 4.016534 \\ \mathrm{H} & 3.234555 \\ \mathrm{H} & 5.324846 \\ \mathrm{H} & 5.421544 \\ \mathrm{H} & -2.356813 \\ \mathrm{H} & -2.546247 \\ \mathrm{H} & -0.488893 \\ \mathrm{H} & 1.713395 \\ \mathrm{C} & 3.649293 \\ \mathrm{H} & 3.506598 \\ \mathrm{C} & 3.511682 \\ \mathrm{H} & 3.556616\end{array}$

2.589289

$-1.811801$

$3.396058-2.715614$

$2.547243-1.787478$

$\begin{array}{ll}0.774291 & -0.080607\end{array}$

$\begin{array}{ll}5.149647 & -1.293531\end{array}$

$\begin{array}{ll}6.603438 & -0.939484\end{array}$

$\begin{array}{ll}5.737087 & 0.326646\end{array}$

$3.356091 \quad 0.918086$

$\begin{array}{ll}1.559554 & 1.923835\end{array}$

$\begin{array}{ll}3.201469 & 0.050933\end{array}$

TS $_{\mathrm{D}-\mathrm{D} \text { * }}$

$\begin{array}{lrrr}\mathrm{C} & -0.532491 & -1.157748 & 0.732978 \\ \mathrm{C} & -0.023106 & 0.004461 & 1.357642 \\ \mathrm{C} & -0.276377 & 1.269629 & 0.698686 \\ \mathrm{C} & -0.276377 & 1.269629 & -0.698686 \\ \mathrm{C} & -0.023106 & 0.004461 & -1.357642 \\ \mathrm{C} & -0.532491 & -1.157748 & -0.732978 \\ \mathrm{C} & -0.754879 & -2.297990 & 1.650273 \\ \mathrm{C} & 0.080713 & -2.438445 & 2.799729 \\ \mathrm{C} & 1.057331 & -1.401624 & 3.107247 \\ \mathrm{C} & 0.905396 & -0.139121 & 2.475970 \\ \mathrm{C} & 0.905396 & -0.139121 & -2.475970 \\ \mathrm{C} & 1.057331 & -1.401624 & -3.107247 \\ \mathrm{C} & 0.080713 & -2.438445 & -2.799729 \\ \mathrm{C} & -0.754879 & -2.297990 & -1.650273 \\ \mathrm{C} & -0.582423 & 2.493786 & 1.431078 \\ \mathrm{C} & -0.701359 & 3.727246 & 0.730303 \\ \mathrm{C} & -0.701359 & 3.727246 & -0.730303 \\ \mathrm{C} & -0.582423 & 2.493786 & -1.431078 \\ \mathrm{C} & -0.926528 & 4.906817 & -1.478564 \\ \mathrm{C} & -1.096075 & 4.877709 & -2.849895 \\ \mathrm{C} & -1.076165 & 3.648037 & -3.527145 \\ \mathrm{C} & -0.829046 & 2.483851 & -2.826129\end{array}$

$\begin{array}{lrrrr}\mathrm{C} & -0.829046 & 2.483851 & 2.826129 & \mathrm{H} \\ \mathrm{C} & -1.076165 & 3.648037 & 3.527145 & \mathrm{H} \\ \mathrm{C} & -1.096075 & 4.877709 & 2.849895 & \mathrm{H} \\ \mathrm{C} & -0.926528 & 4.906817 & 1.478564 & \mathrm{H} \\ \mathrm{C} & 2.108037 & -1.590698 & 4.027873 & \mathrm{H} \\ \mathrm{C} & 2.984984 & -0.565871 & 4.340316 & \mathrm{H} \\ \mathrm{C} & 2.840756 & 0.683522 & 3.718360 & \mathrm{H} \\ \mathrm{C} & 1.827217 & 0.887320 & 2.799313 & \mathrm{H} \\ \mathrm{C} & -2.035413 & -4.240197 & 2.430556 & \mathrm{H} \\ \mathrm{C} & -1.133571 & -4.445329 & 3.478337 & \mathrm{H} \\ \mathrm{C} & -0.111118 & -3.531631 & 3.668699 & \mathrm{H} \\ \mathrm{C} & -0.111118 & -3.531631 & -3.668699 & \mathrm{H} \\ \mathrm{C} & -1.133571 & -4.445329 & -3.478337 & \mathrm{H} \\ \mathrm{C} & -2.035413 & -4.240197 & -2.430556 & \mathrm{H} \\ \mathrm{C} & 1.827217 & 0.887320 & -2.799313 & \mathrm{H} \\ \mathrm{C} & 2.840756 & 0.683522 & -3.718360 & \mathrm{H} \\ \mathrm{C} & 2.984984 & -0.565871 & -4.340316 & \mathrm{H} \\ \mathrm{C} & 2.108037 & -1.590698 & -4.027873 & \mathrm{H} \\ \mathrm{H} & -0.992434 & 5.862433 & -0.971618 & \mathrm{C} \\ \mathrm{H} & -1.273552 & 5.801553 & -3.393670 & \mathrm{H} \\ \mathrm{H} & -1.259145 & 3.607172 & -4.597319 & \mathrm{C} \\ \mathrm{H} & -0.823996 & 1.539276 & -3.355467 & \mathrm{H}\end{array}$

$\begin{array}{crr}\mathrm{H} & -0.823996 \\ \mathrm{H} & -1.259145 \\ \mathrm{H} & -1.273552 & \\ \mathrm{H} & -0.992434 & \\ \mathrm{H} & 2.252713 & -2.5 \\ \mathrm{H} & 3.791970 & -0.7 \\ \mathrm{H} & 3.540027 & \\ \mathrm{H} & 1.761976\end{array}$

4.024168

$-1.130669$

$-4.723267$

$-1.296573$

$-4.391243$

$-0.057976$

$-2.565323$

1.663100

$-2.556630$

$-0.833870$

$-4.342834$

$-2.463991$

$-5.453373$

$-3.359863$

$-4.758567$

$-2.537753$

$\begin{array}{ll}1.166640 & 1.403649\end{array}$

$0.528745 \quad 2.260961$

$\begin{array}{ll}-1.766467 & 1.117457\end{array}$

$-1.064828 \quad 1.923645$ 


\section{References}

1. Fu, J.-m.; Snieckus, V. Can. J. Chem. 2000, 78, 905.

2. Lee, M.; Rangisetty, J. B.; Pullagurla, M. R.; Dukat, M.; Setola, V.; Roth, B. L.; Glennon, R. A. Bioorg. Med. Chem. Lett. 2005, 15, 1707.

3. (a) Seiders, T. J.; Elliott, E. L.; Grube, G. H.; Siegel, J. S. J. Am. Chem. Soc. 1999, 121, 7804. (b) Hagen, S.; Bratcher, M. S.; Erickson, M. S.; Zimmermann, G.; Scott, L. T. Angew. Chem., Int. Ed. Engl. 1997, 36,406

4. Grunder, S.; Muñoz Torres, D.; Marquardt, C.; Błaszczyk, A.; Krupke, R.; Mayor, M. Eur. J. Org. Chem. 2011, 478 .

5. Stoll, R. S.; Peters, M. V.; Kuhn, A.; Heiles, S.; Goddard, R.; Bühl, M.; Thiele, C. M.; Hecht, S. J. Am . Chem. Soc. 2009, 131, 357.

6. Yoshida, H.; Asatsu, Y.; Mimura, Y.; Ito, Y.; Ohshita, J.; Takaki, K. Angew. Chem., Int. Ed. 2011, 50, 9676.

7. Saleh, M.; Baumgarten, M.; Mavrinskiy, A.; Schäfer, T.; Müllen, K. Macromolecules 2010, 43, 137.

8. Yang, Y. S.; Yasuda, T.; Kakizoe, H.; Mieno, H.; Kino, H.; Tateyama, Y.; Adachi, C. Chem. Commun. 2013, 49, 6483.

9. Jones, C. S.; Elliott, E.; Siegel, J. S. Synlett 2004, 187.

10. Toyota, S.; Azami, R.; Iwanaga, T.; Matsuo, D.; Orita, A.; Otera, J. Bull. Chem. Soc. Jpn. 2009, 82, 1287.

11. Hundertmark, T.; Littke, A. F.; Buchwald, S. L.; Fu, G. C. Org. Lett. 2000, 2, 1729.

12. Shi, S.; Zhang, Y. Synlett 2007, 1843.

13. Wu, Y.-T.; Bandera, D.; Maag, R.; Linden, A.; Baldridge, K. K.; Siegel, J. S. J. Am. Chem. Soc. 2008, $130,10729$.

14. Shi, W.; Luo, Y.; Luo, X.; Chao, L.; Zhang, H.; Wang, J.; Lei, A. J. Am. Chem. Soc. 2008, 130, 14713.

15. Altomare, A.; Burla, M. C.; Camalli, M.; Cascarano, G. L.; Giacovazzo, C.; Guagliardi, A.; Moliterni, A. G. G.; Polidori, G.; Spagna, R. J. Appl. Crystallogr. 1999, 32, 115.

16. Sheldrick, G. M. University of Göttingen: Göttingen, Germany, 1997.

17. Frisch, M. J.; Trucks, G. W.; Schlegel, H. B.; Scuseria, G. E.; Robb, M. A.; Cheeseman, J. R.; Scalmani, G.; Barone, V.; Mennucci, B.; Petersson, G. A.; Nakatsuji, H.; Caricato, M.; Li, X.; Hratchian, H. P.; Izmaylov, A. F.; Bloino, J.; Zheng, G.; Sonnenberg, J. L.; Hada, M.; Ehara, M.; Toyota, K.; Fukuda, R.; Hasegawa, J.; Ishida, M.; Nakajima, T.; Honda, Y.; Kitao, O.; Nakai, H.; Vreven, T.; Montgomery, Jr., J. A.; Peralta, J. E.; Ogliaro, F.; Bearpark, M.; Heyd, J. J.; Brothers, E.; Kudin, K. N.; Staroverov, V. N.; Kobayashi, R.; Normand, J.; Raghavachari, K.; Rendell, A.; Burant, J. C.; Iyengar, S. S.; Tomasi, J.; Cossi, M.; Rega, N.; Millam, J. M.; Klene, M.; Knox, J. E.; Cross, J. B.; Bakken, V.; Adamo, C.; Jaramillo, J.; Gomperts, R.; Stratmann, R. E.; Yazyev, O.; Austin, A. J.; Cammi, R.; Pomelli, C.; Ochterski, J. W.; Martin, R. L.; Morokuma, K.; Zakrzewski, V. G.; Voth, G. A.; Salvador, P.; Dannenberg, J. J.; Dapprich, S.; Daniels, A. D.; Farkas, O.; Foresman, J. B.; Ortiz, J. V.; Cioslowski, J.; Fox, D. J. Gaussian 09, Revision C.01, Gaussian, Inc., Wallingford CT, 2010.

18. Becke, A. D. J. Chem. Phys. 1993, 98, 5648.

19. Lee, C.; Yang, W.; Parr, R. G. Phys. Rev. B 1988, 37, 785. 
20. Gonzalez, C.; Schlegel, H. B. J. Chem. Phys. 1989, 90, 2154.

21. Gonzalez, C.; Schlegel, H. B. J. Phys. Chem. 1990, 94, 5523. 


\section{7. ${ }^{1} \mathrm{H}$ and ${ }^{13} \mathrm{C}$ NMR spectra of new compounds}

$2 a$
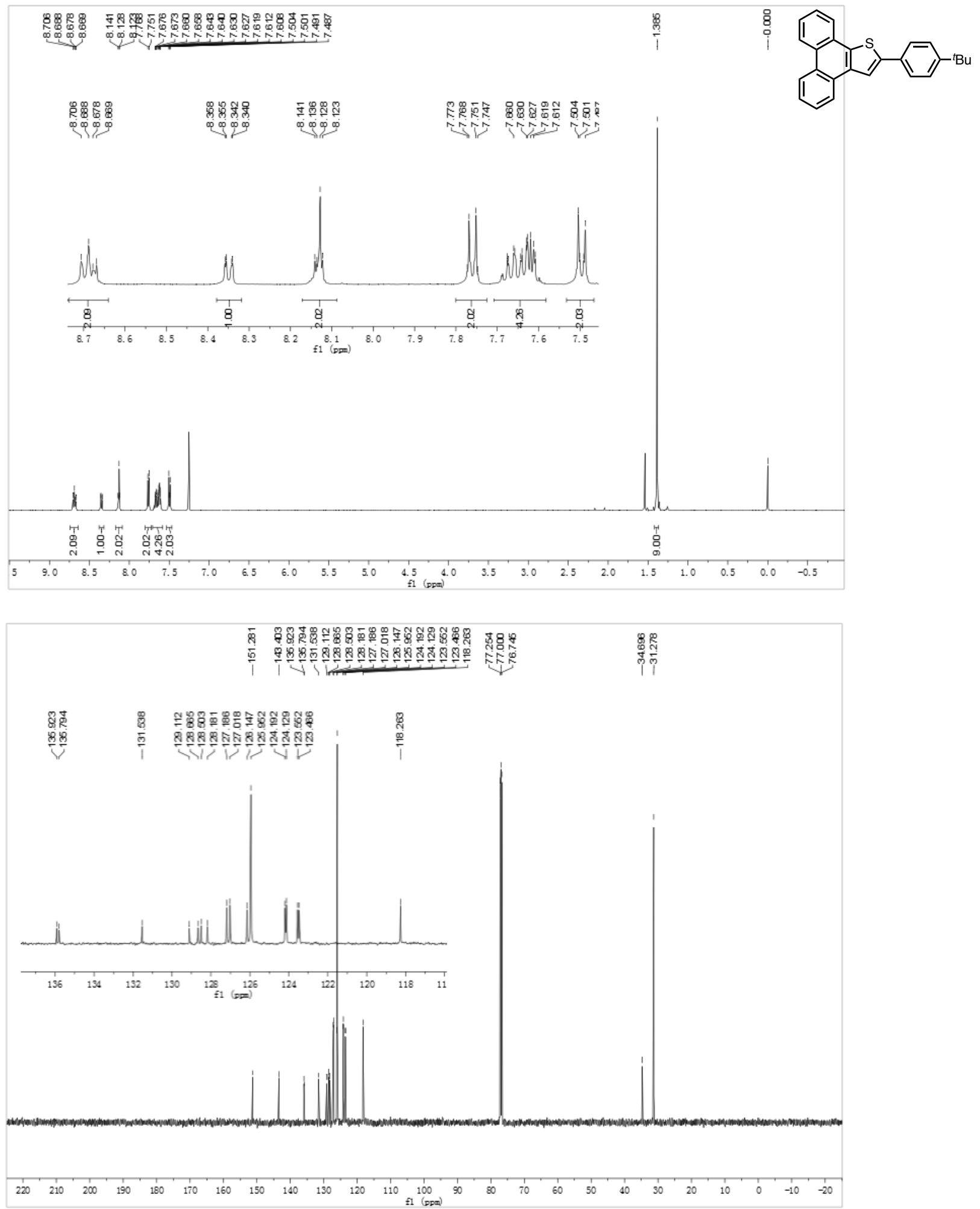
$2 b$
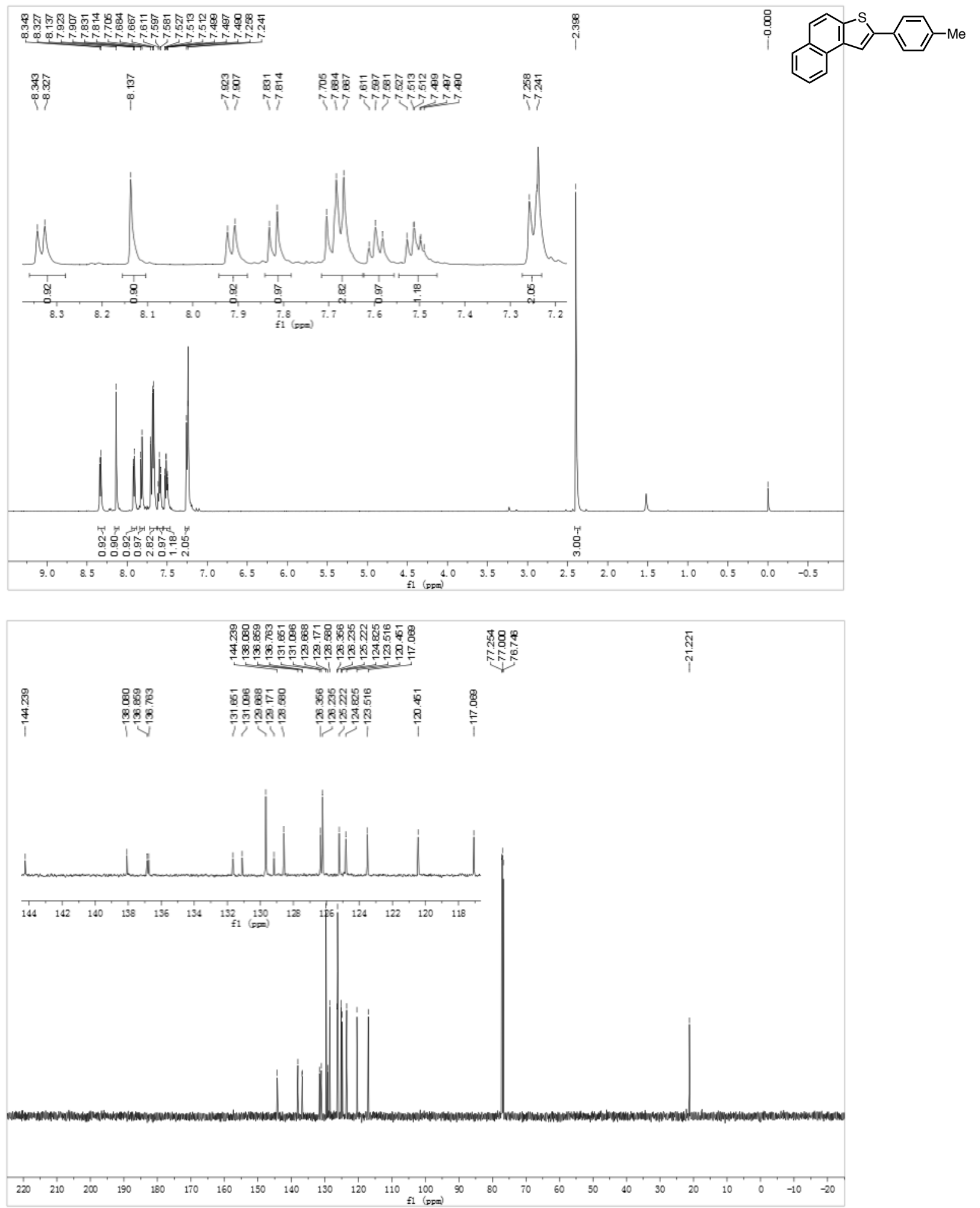
2c

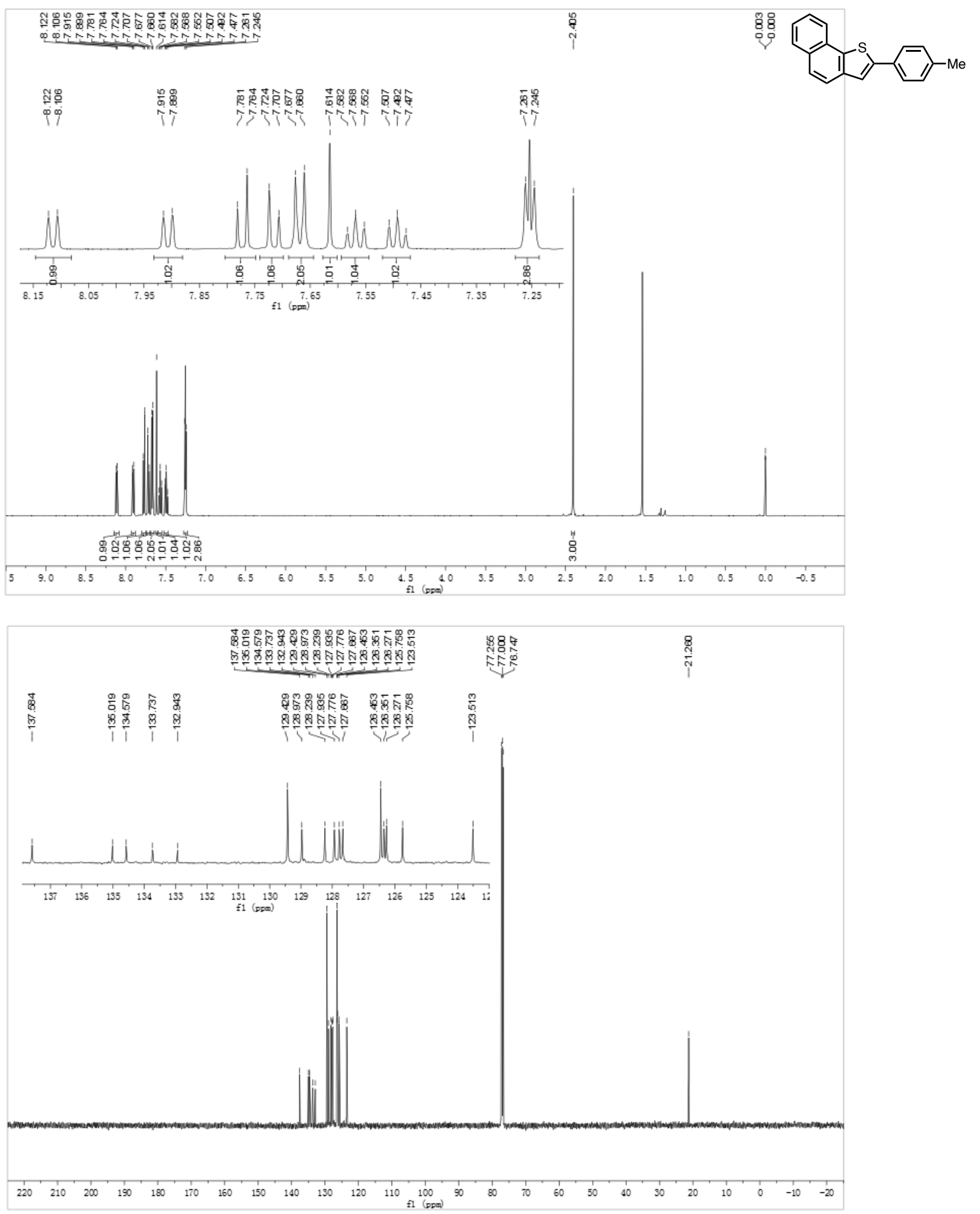




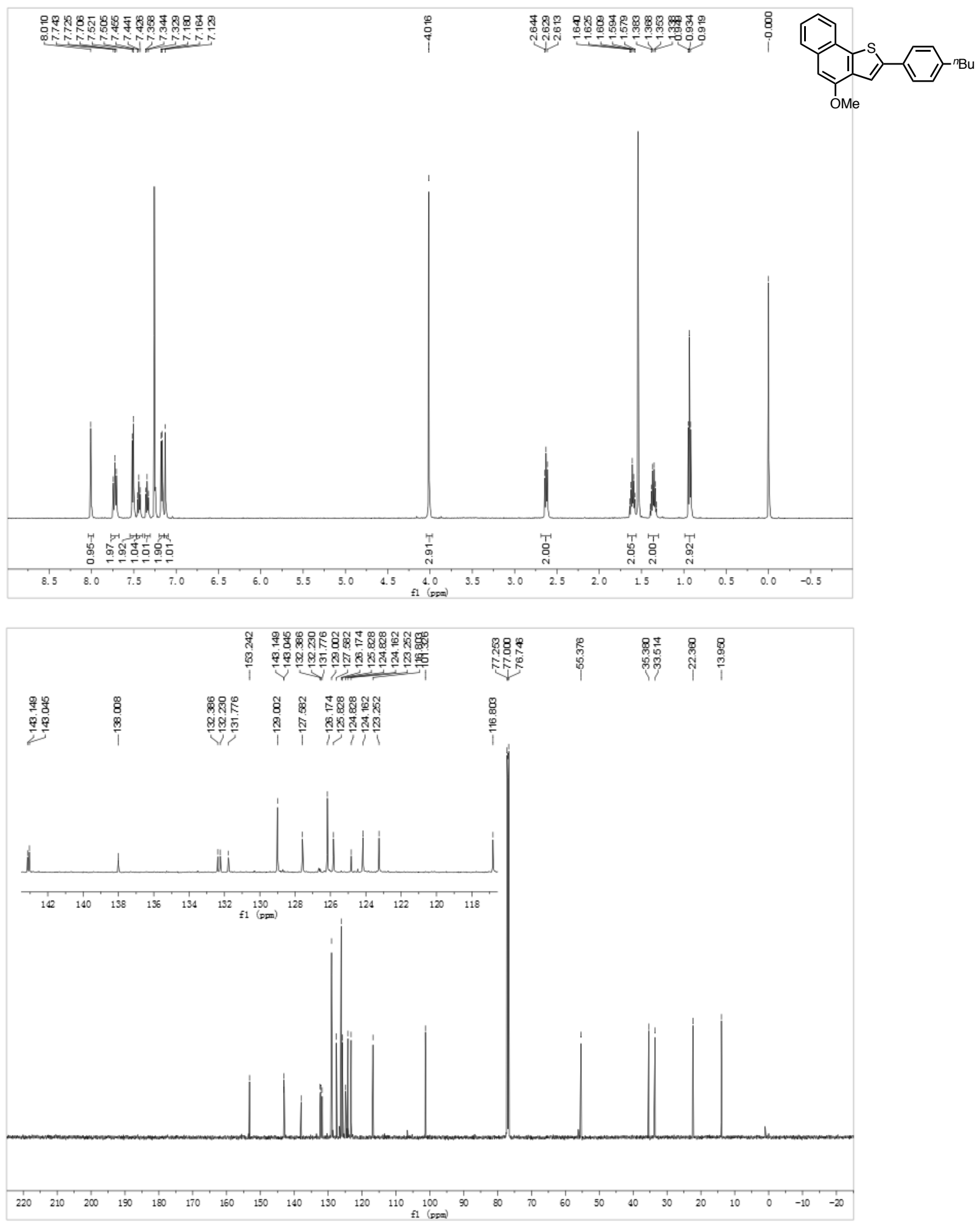


$\mathbf{2 e}$

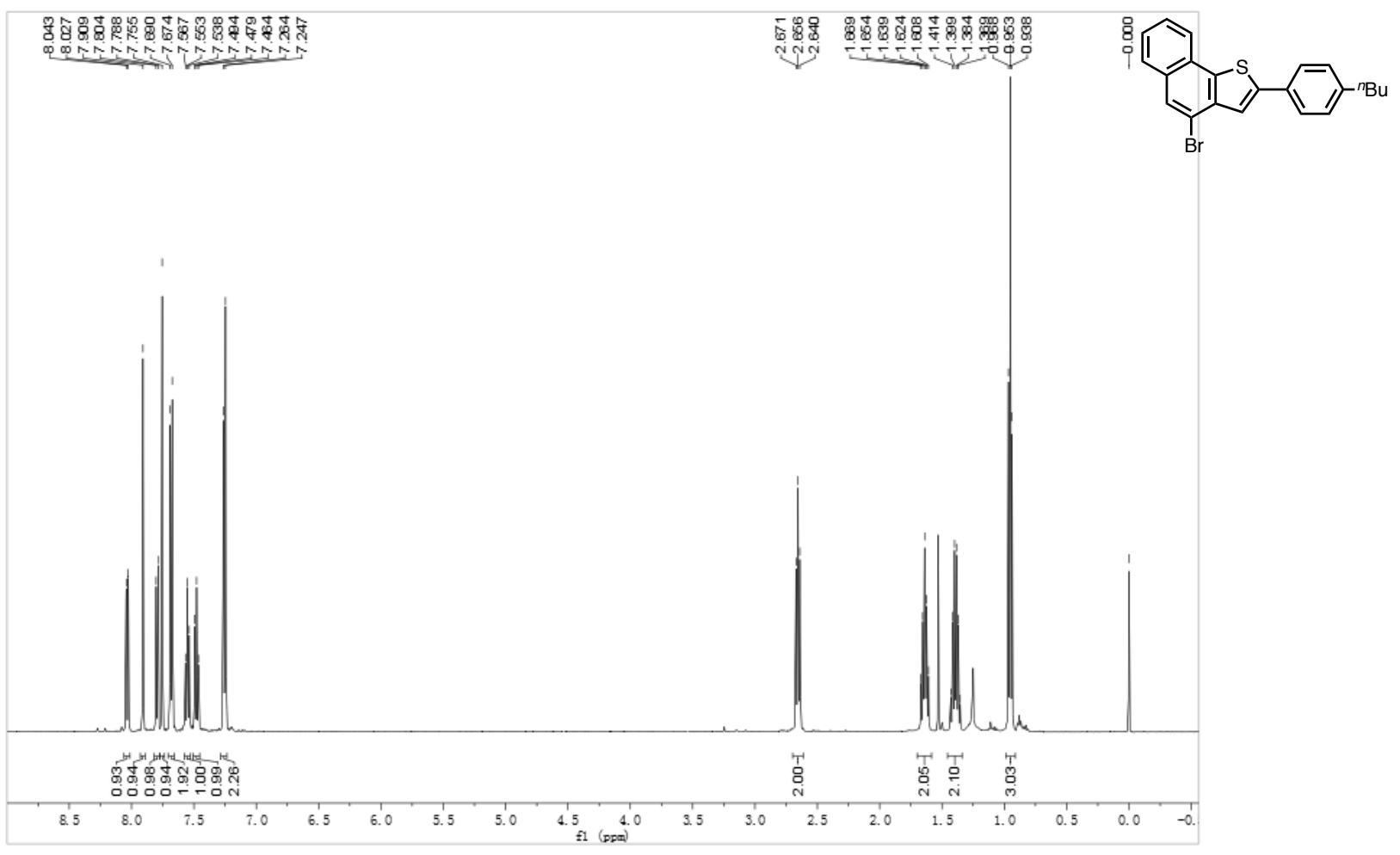

我品

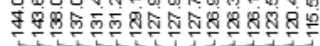

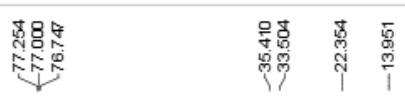

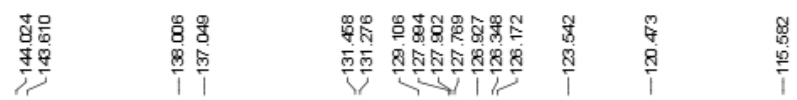
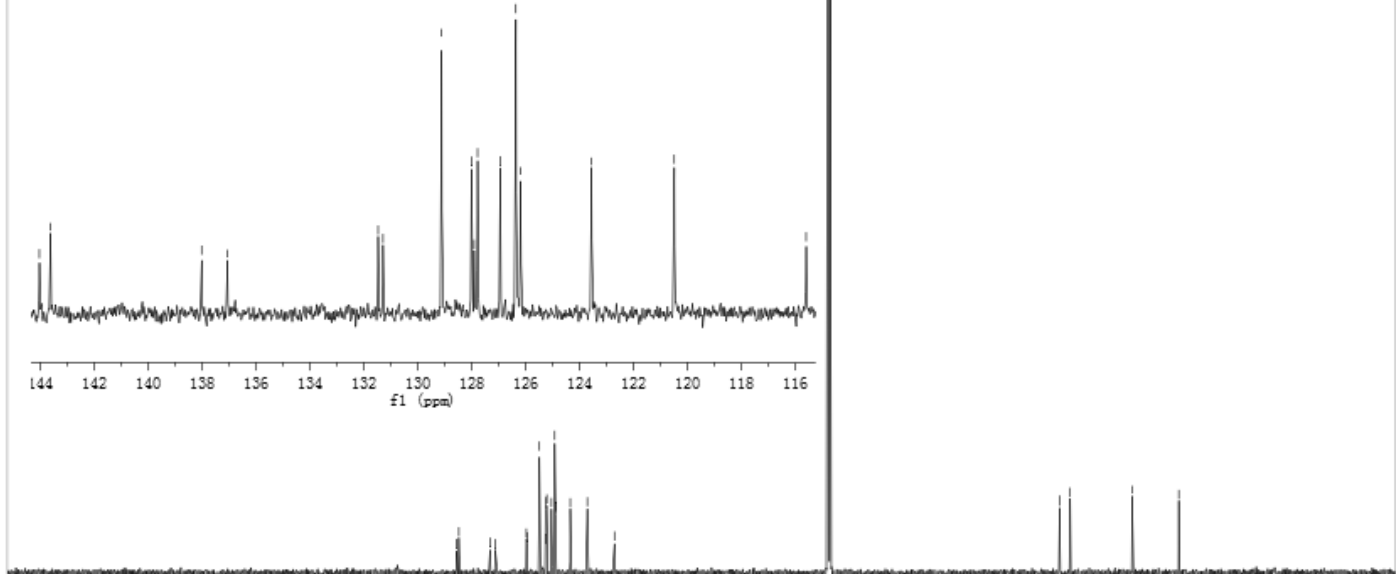

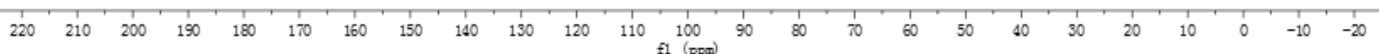




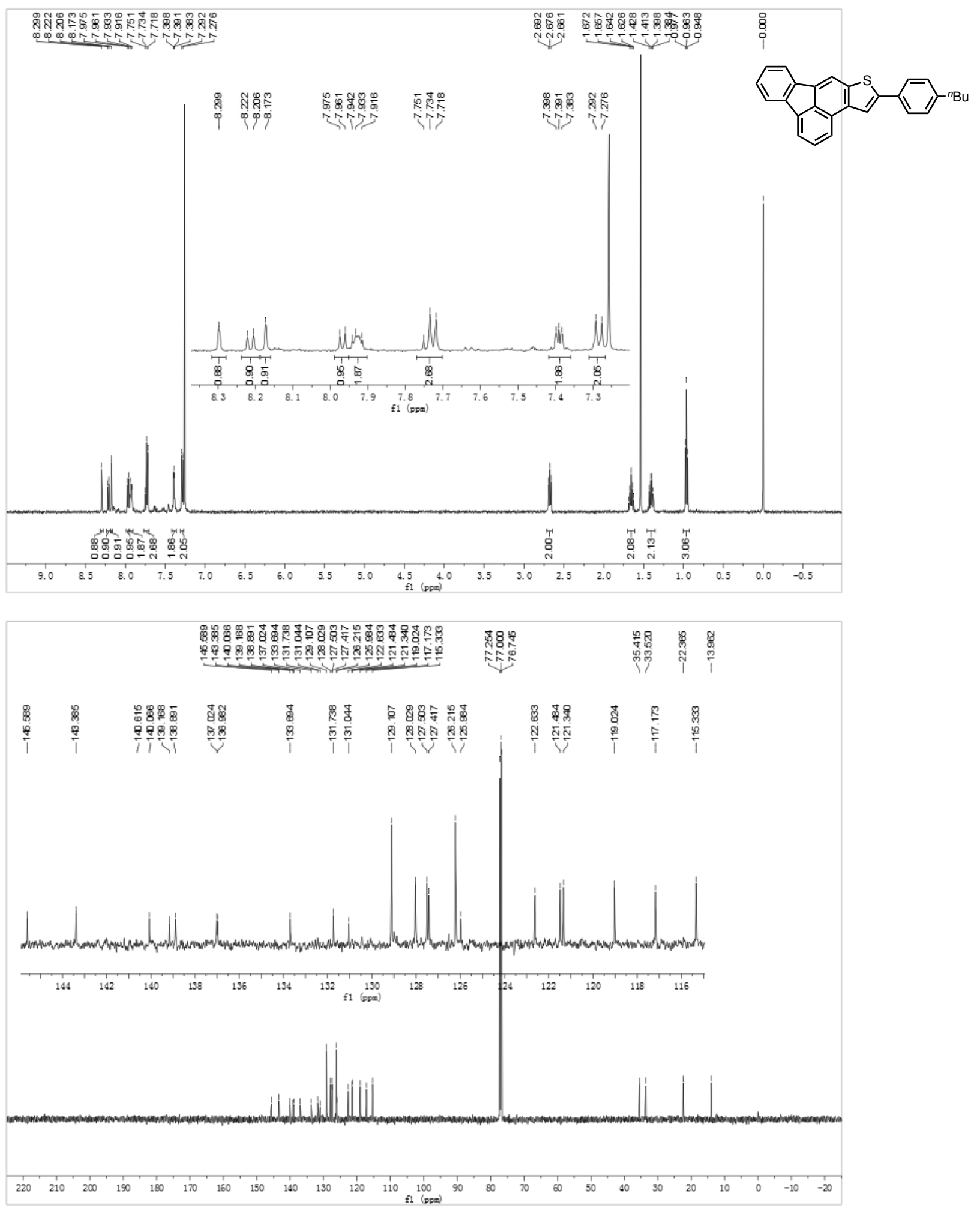


$2 \mathrm{~g}$

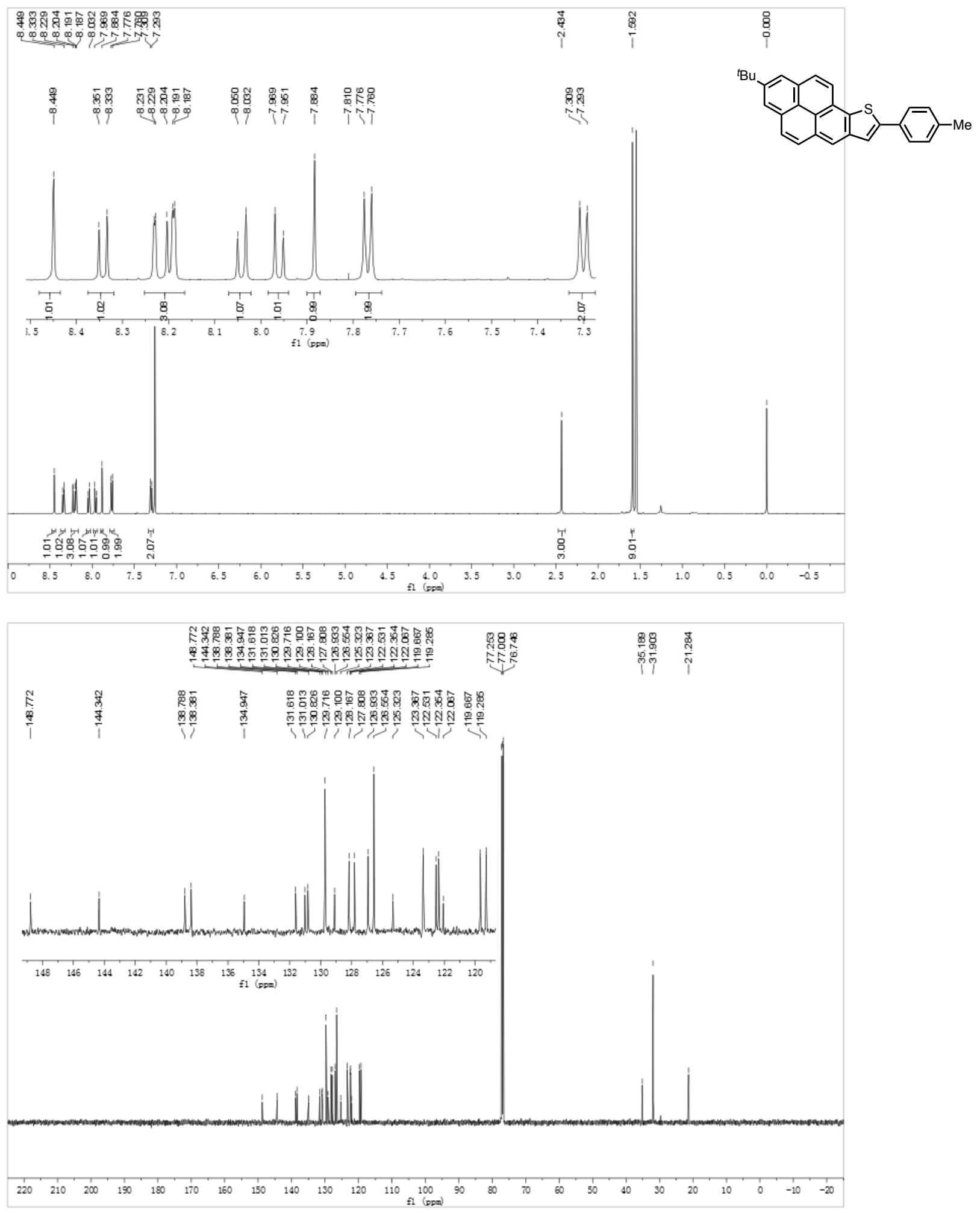


$2 h$

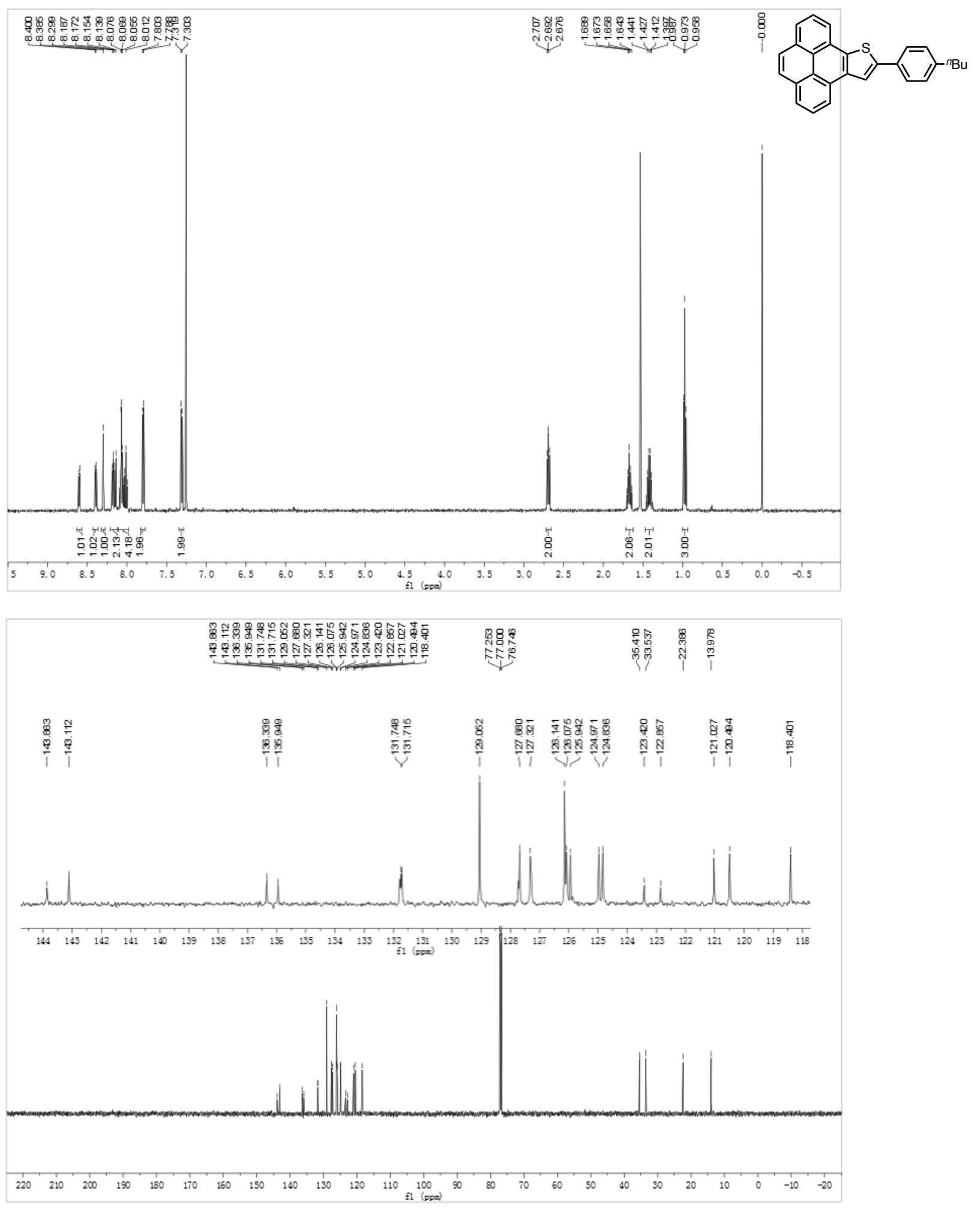


2 i
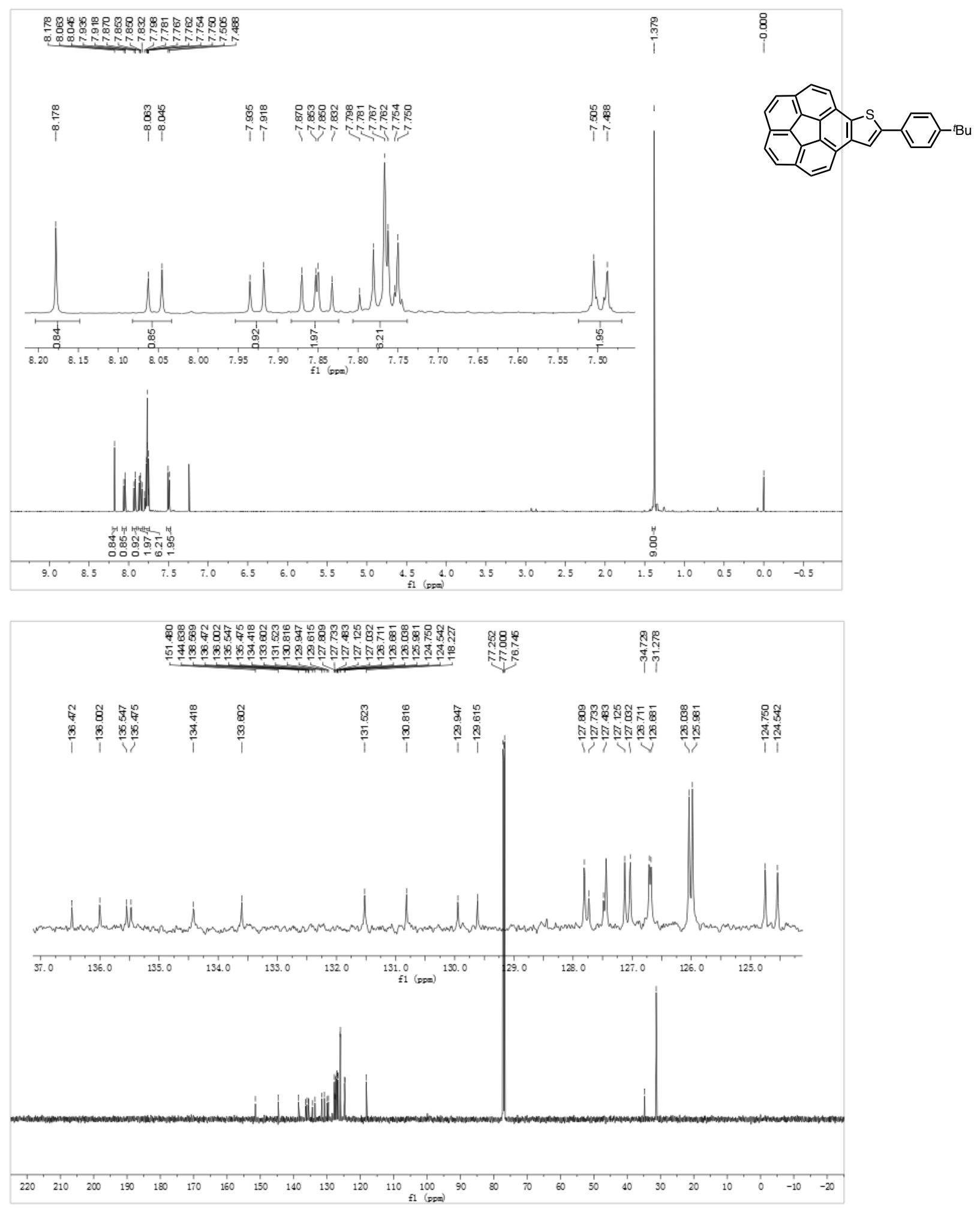

S58 
$2 \mathrm{j}$
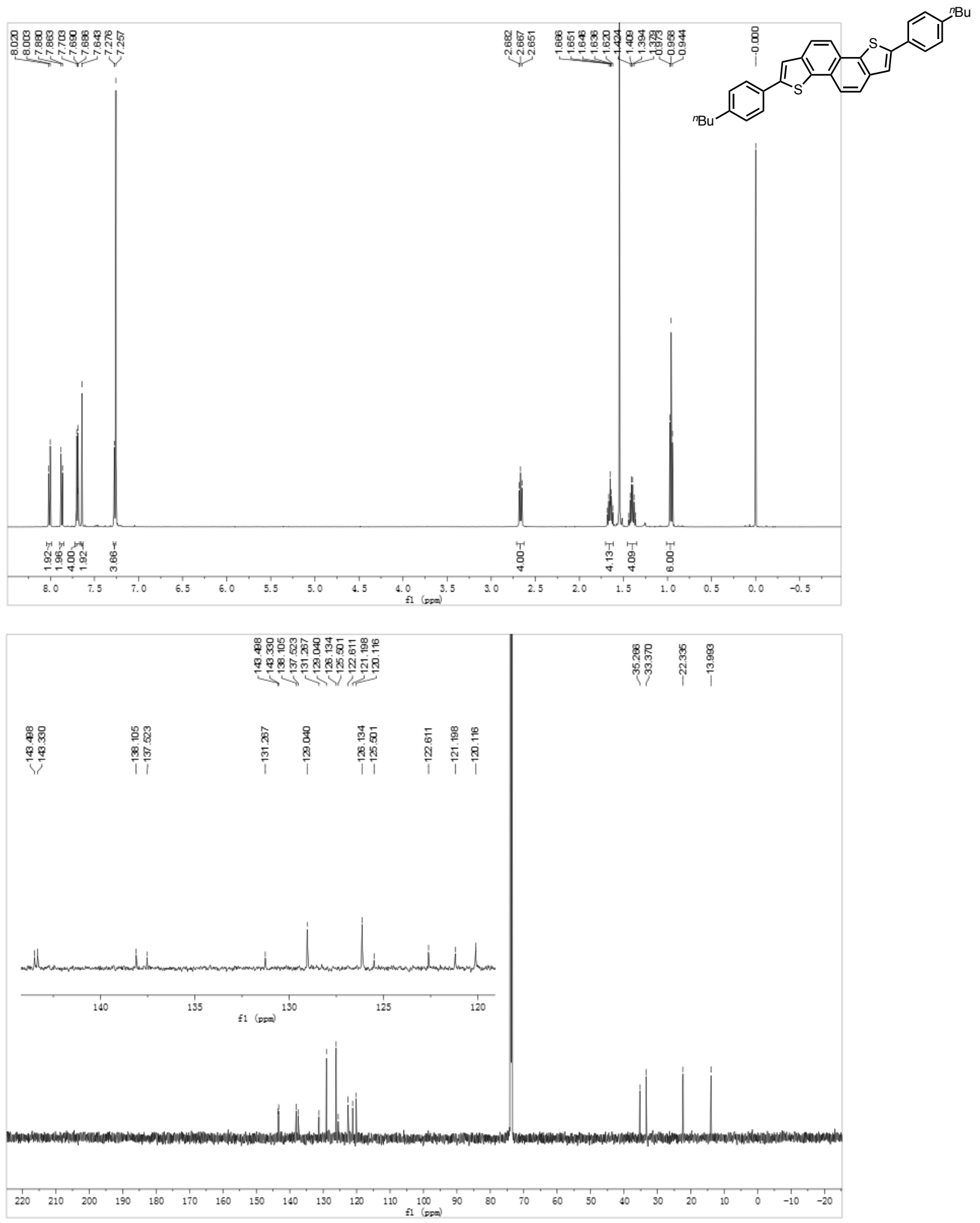
$2 k$

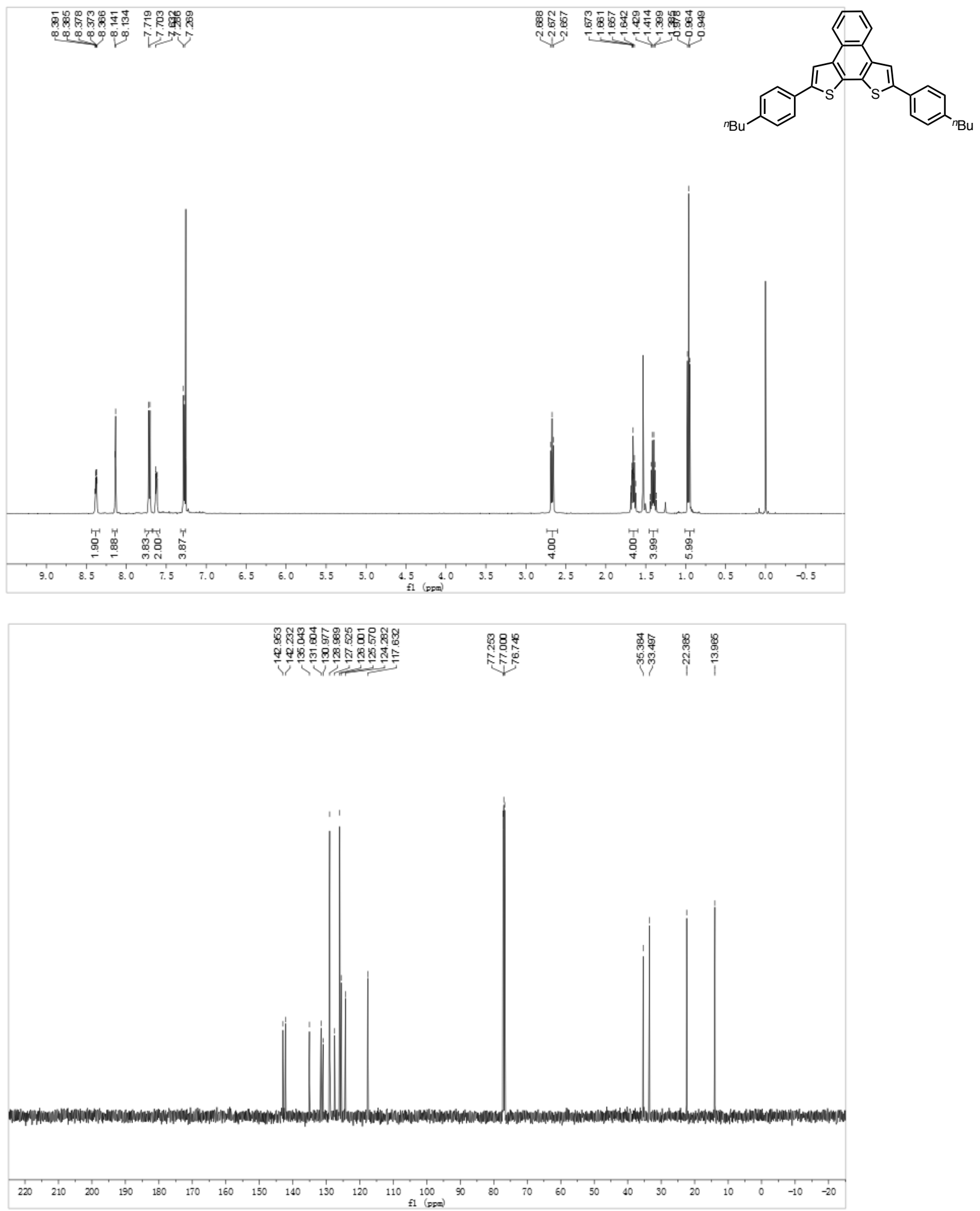


2I
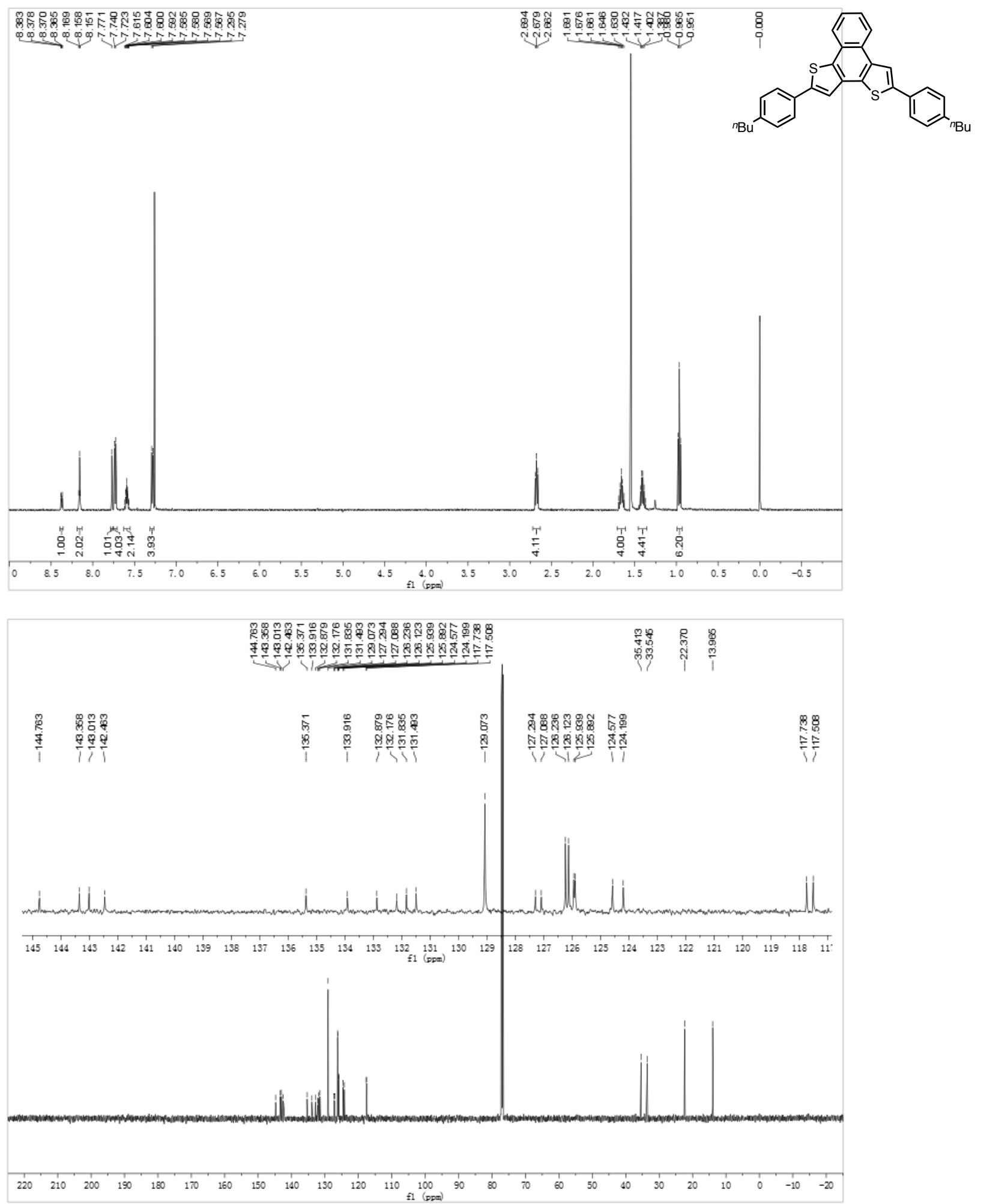

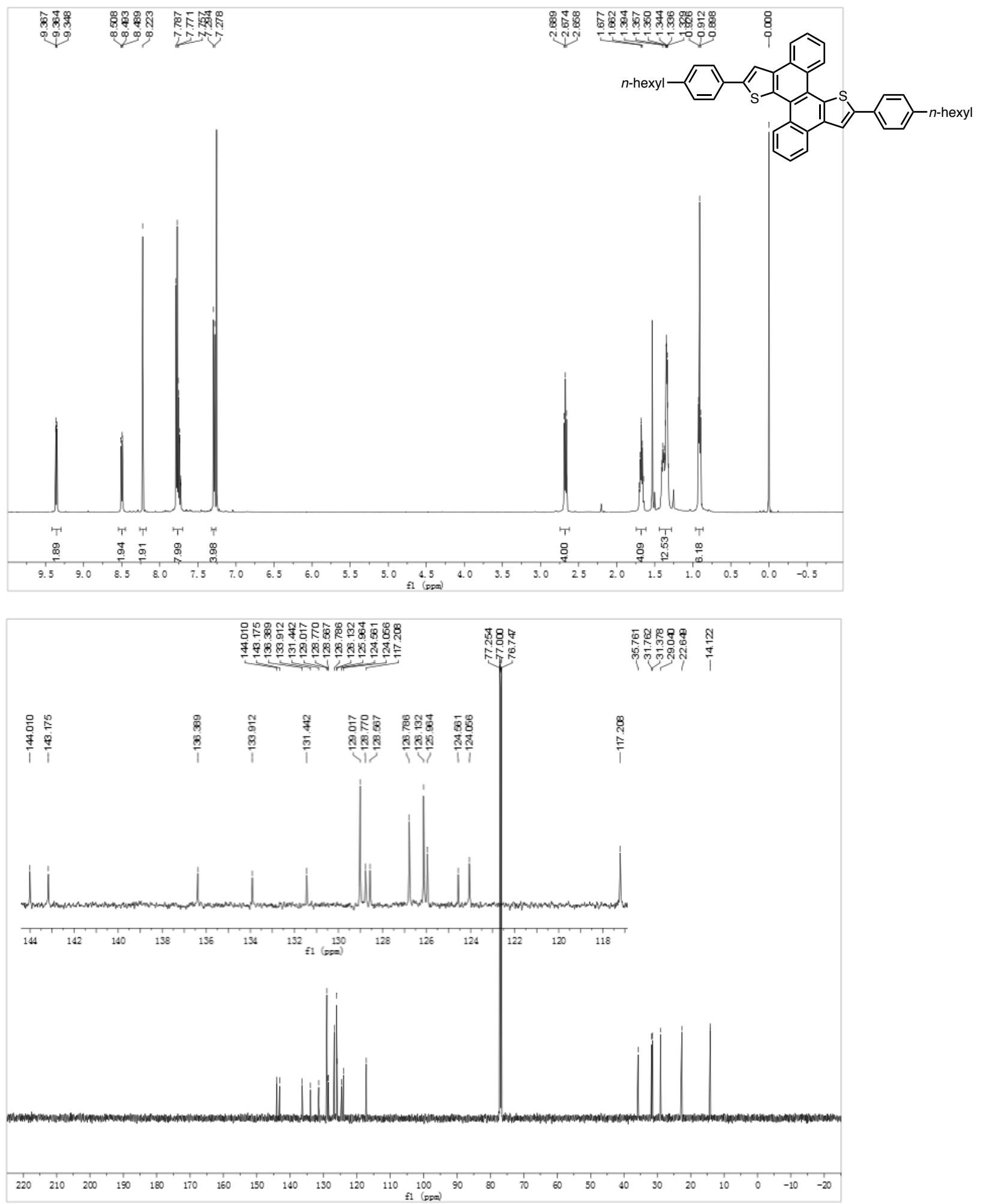
$2 n$
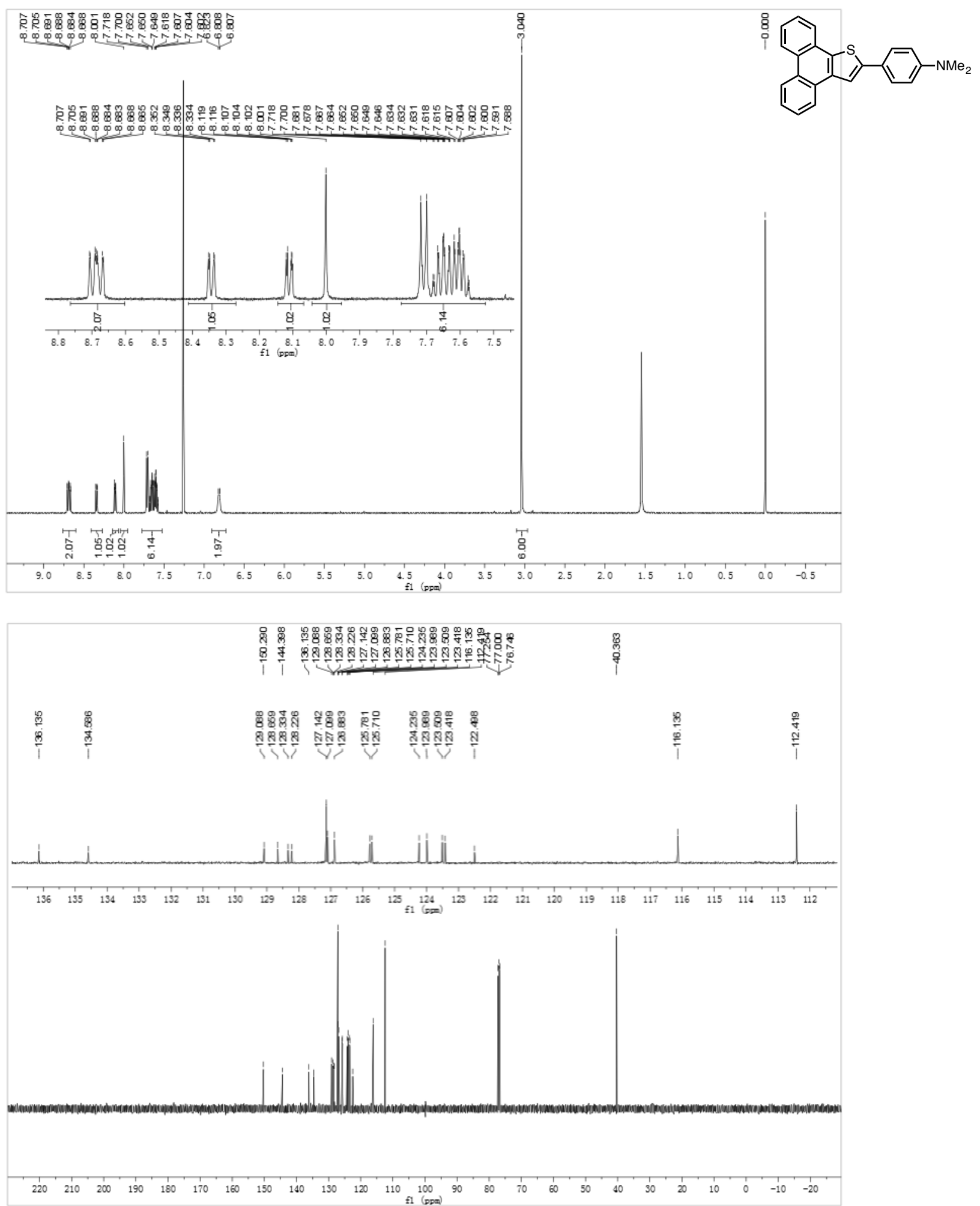
20

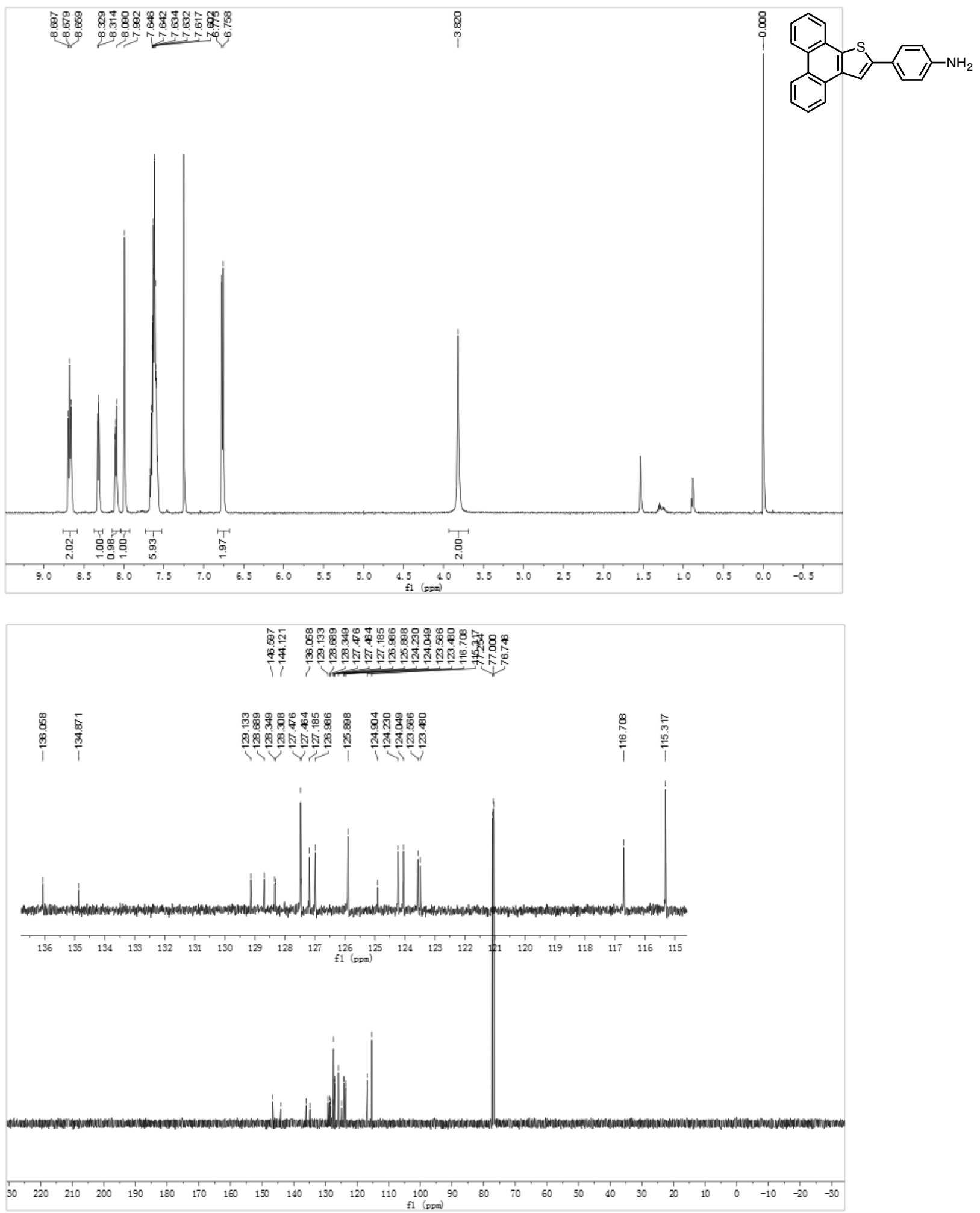


$2 p$
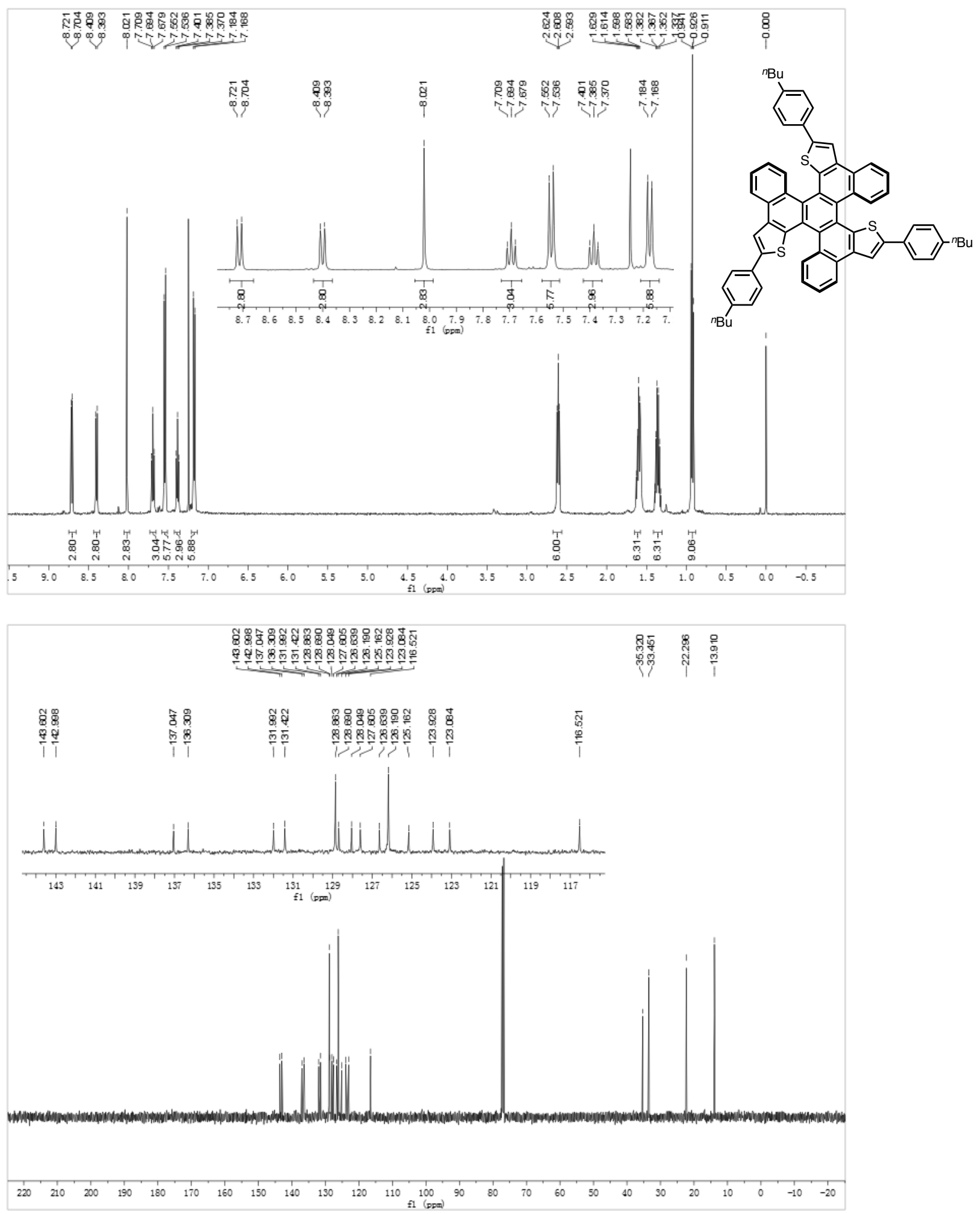
$2 q$
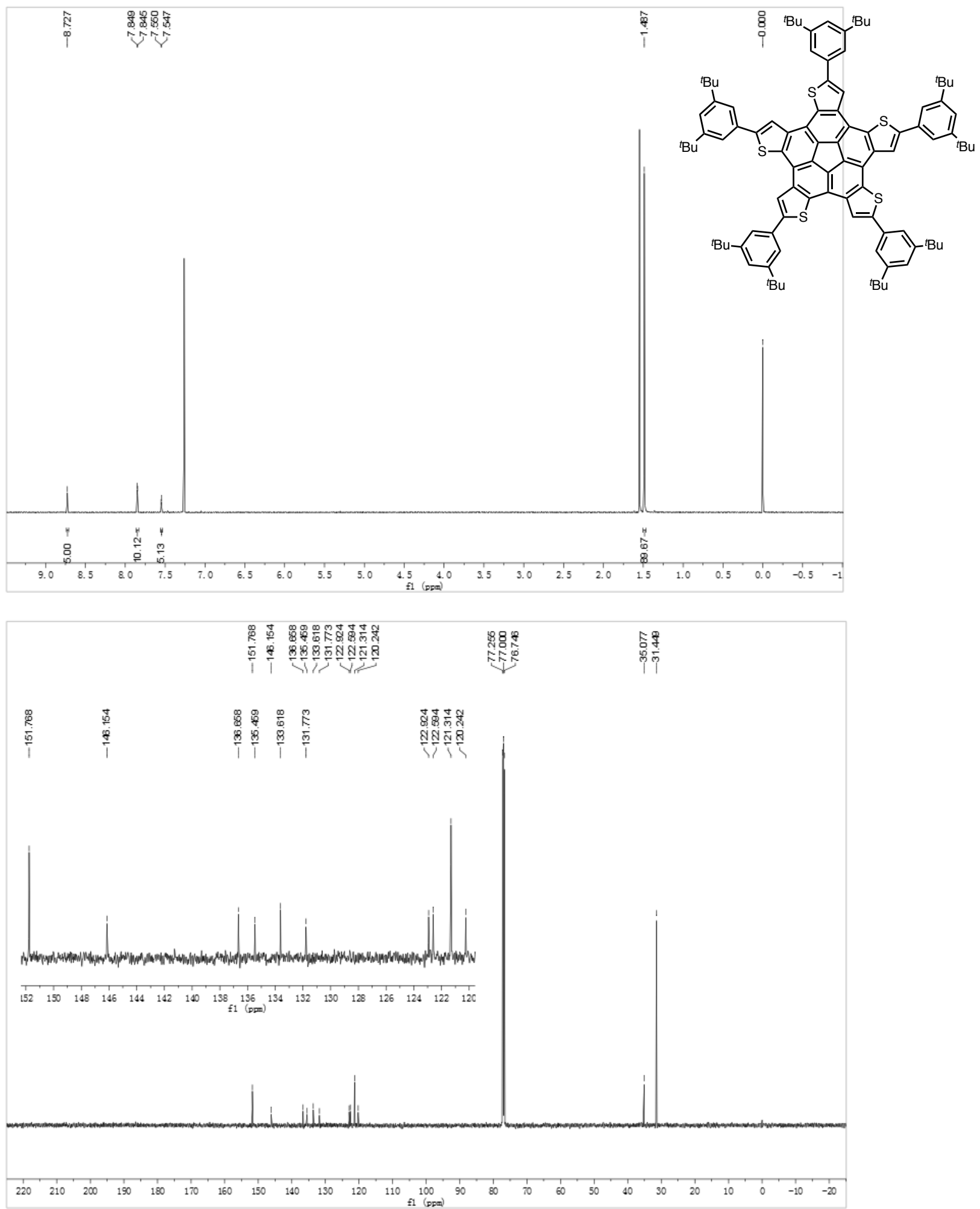


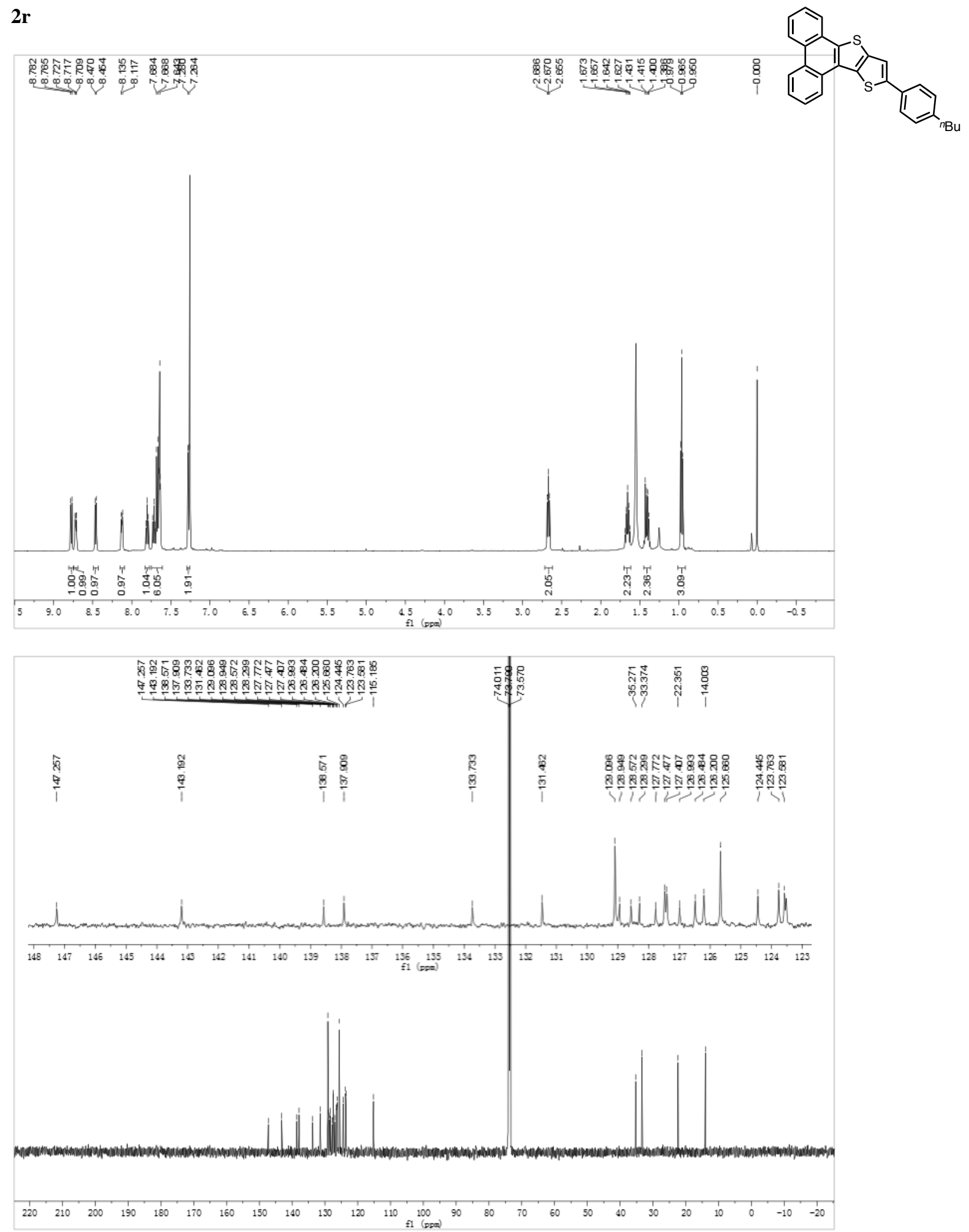


$2 s$

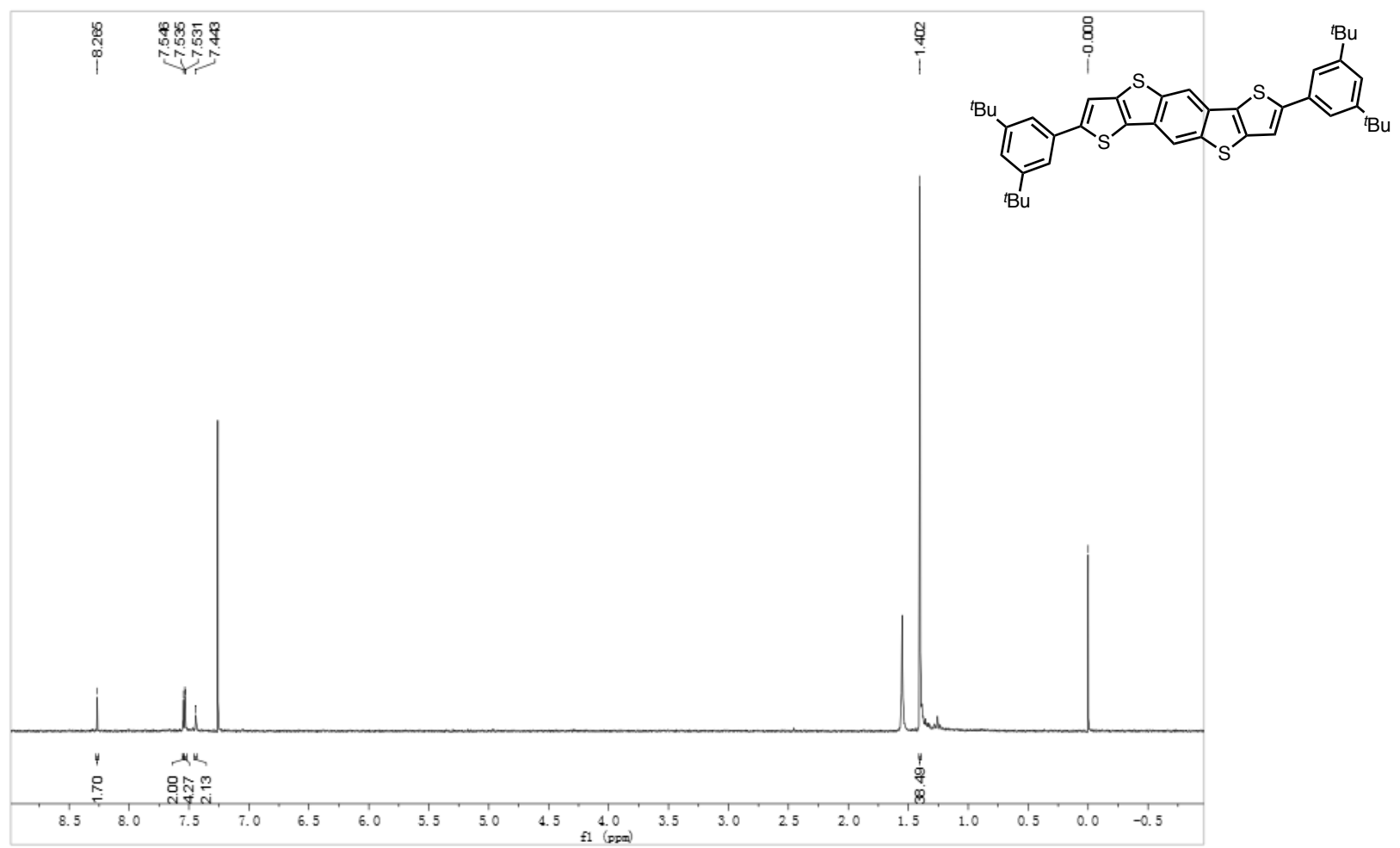

象

후눈

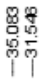

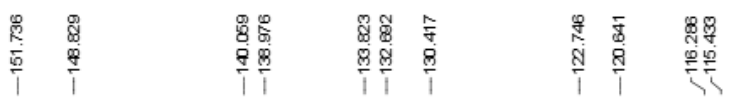

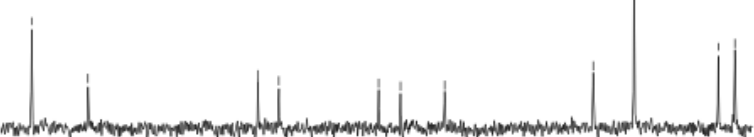

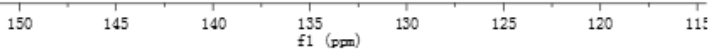

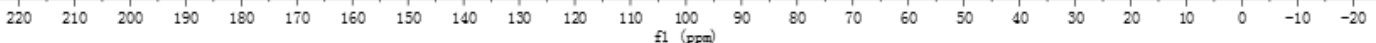



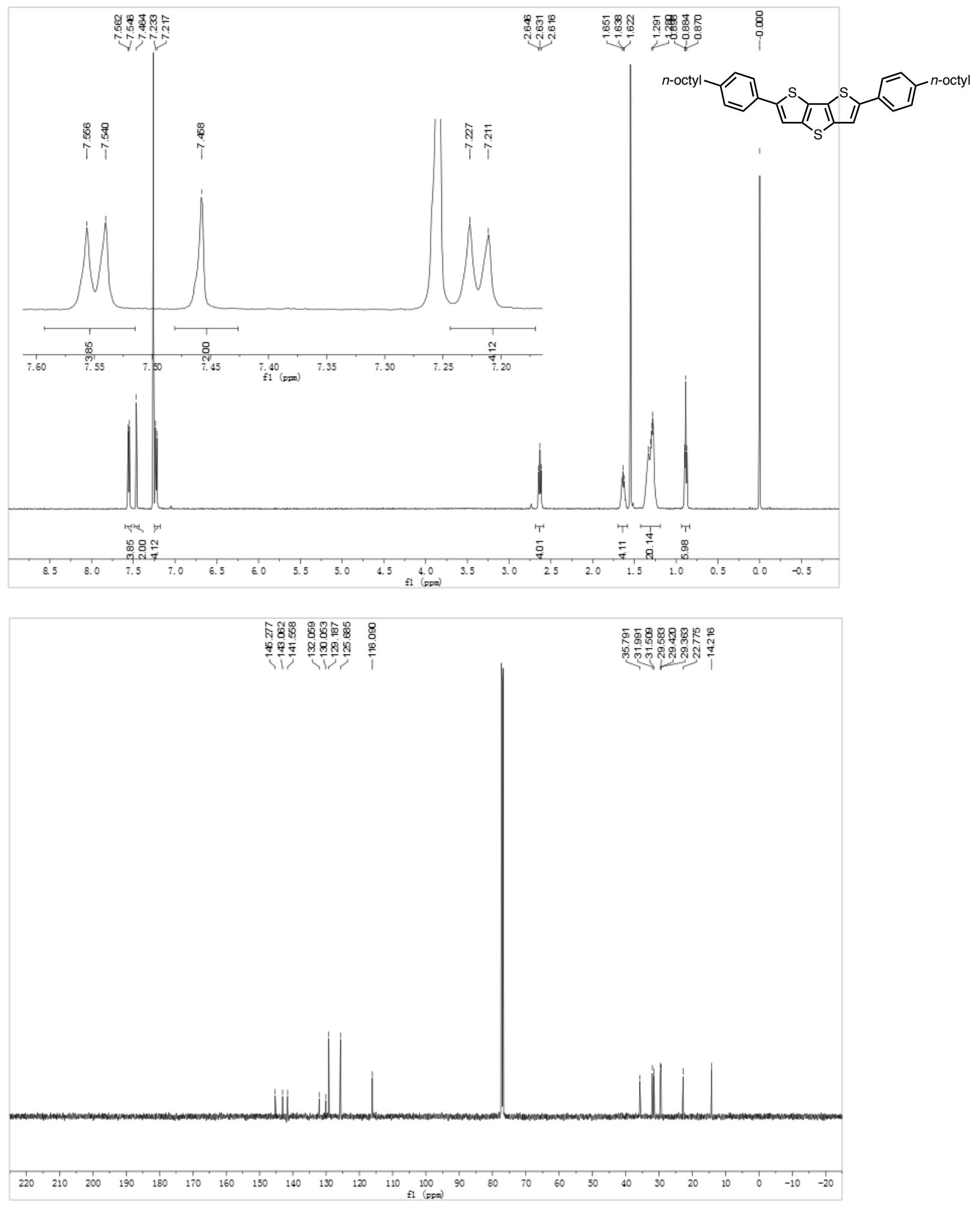
2a-D

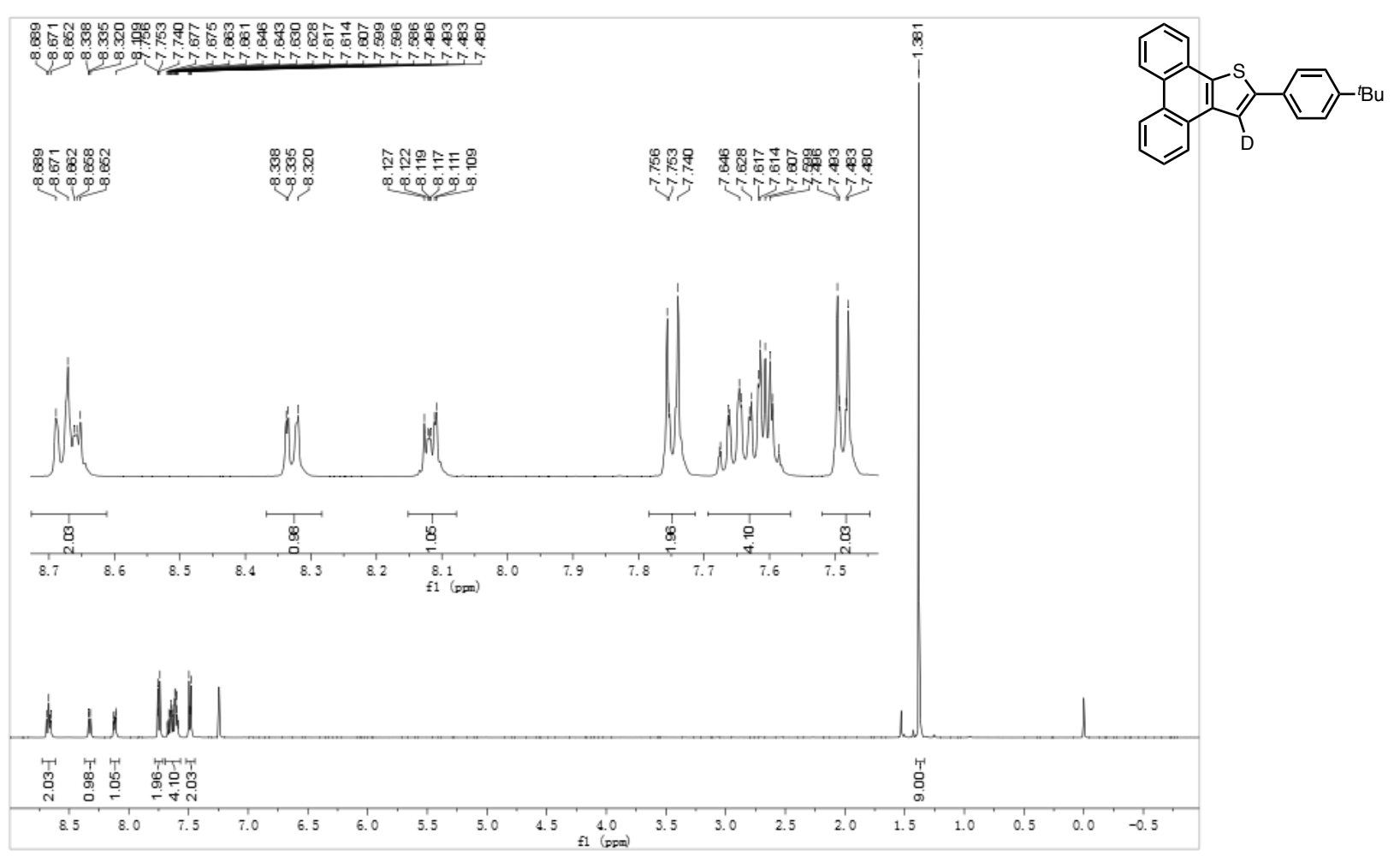


$1 a$

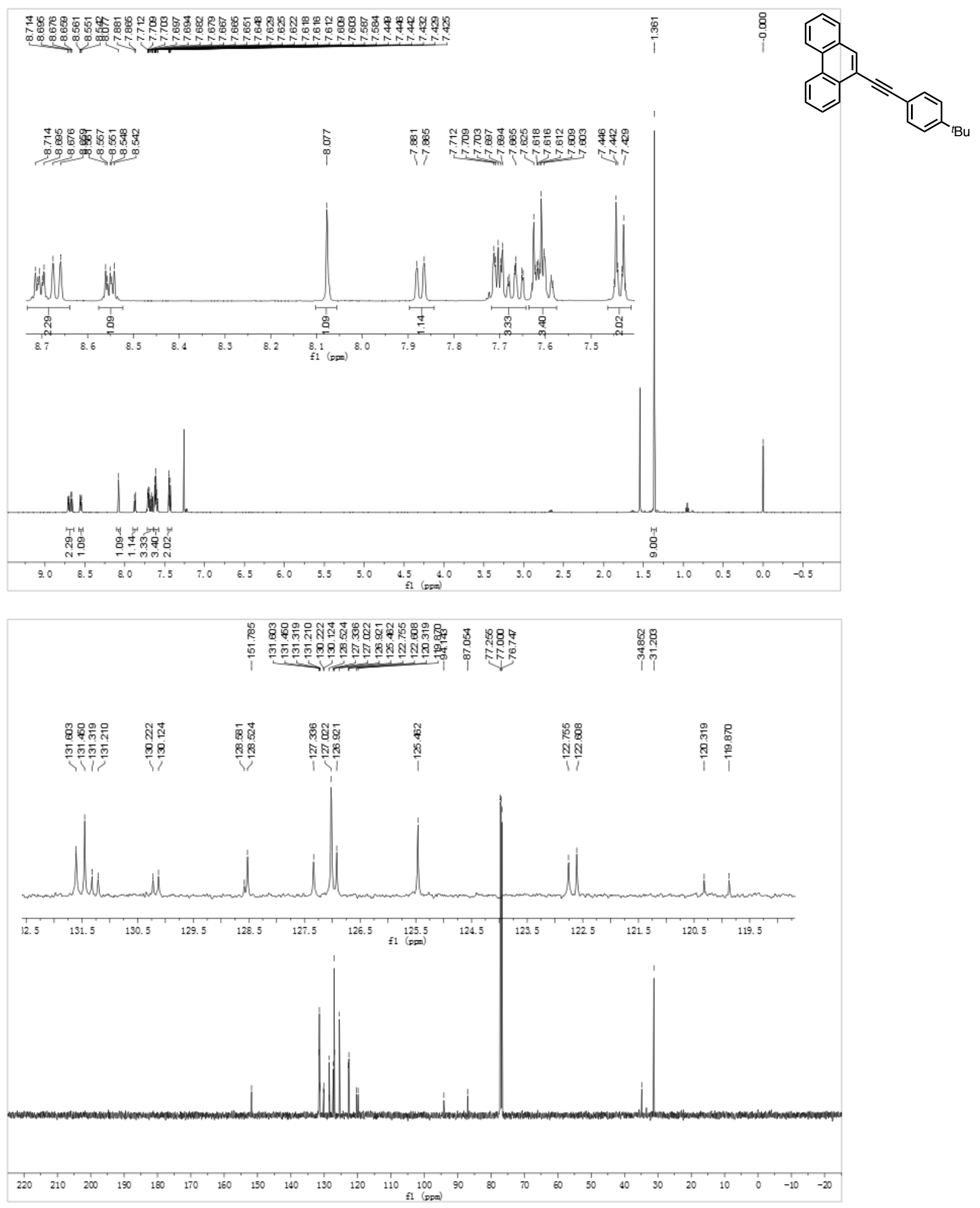


1b
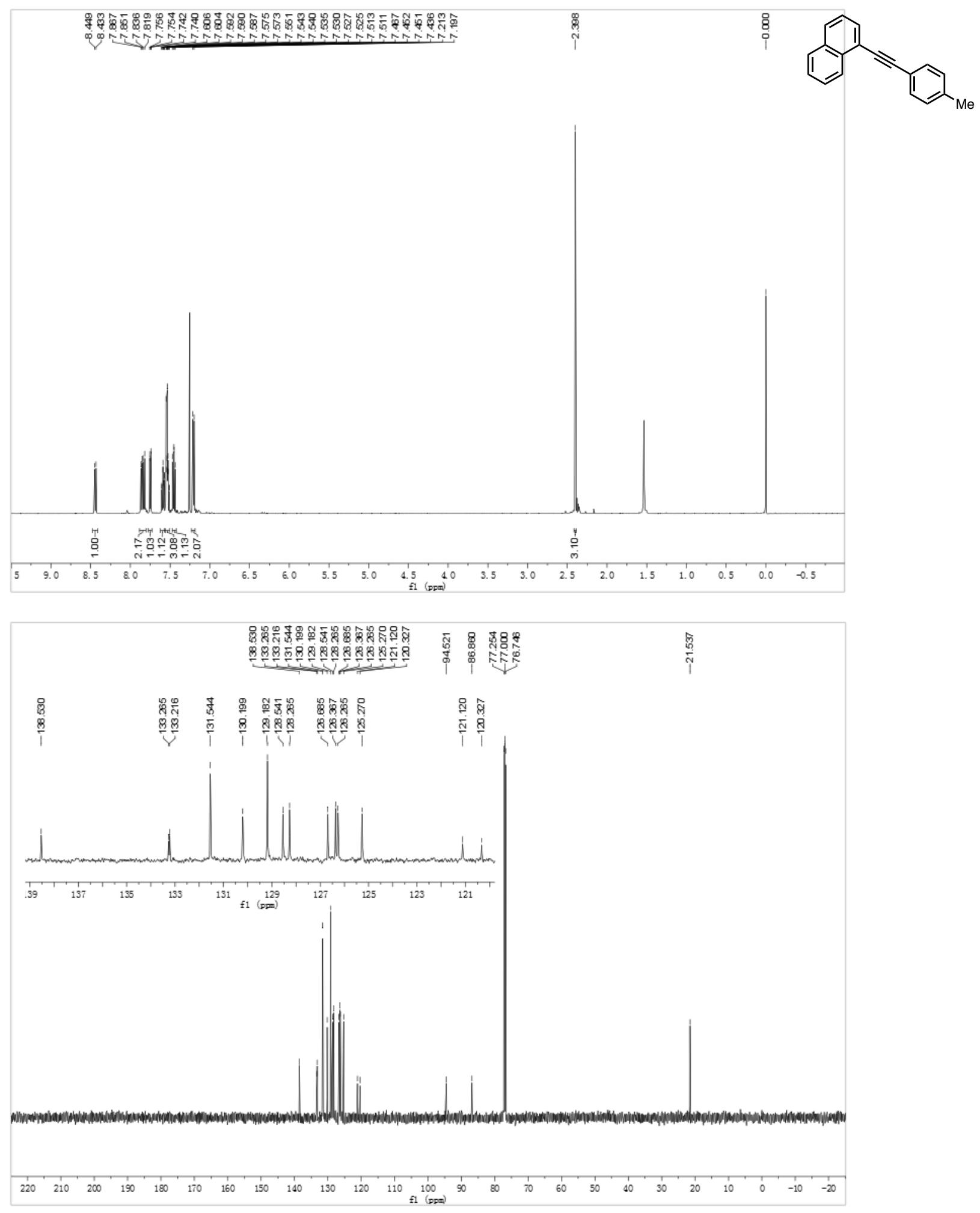

S72 
$1 c$

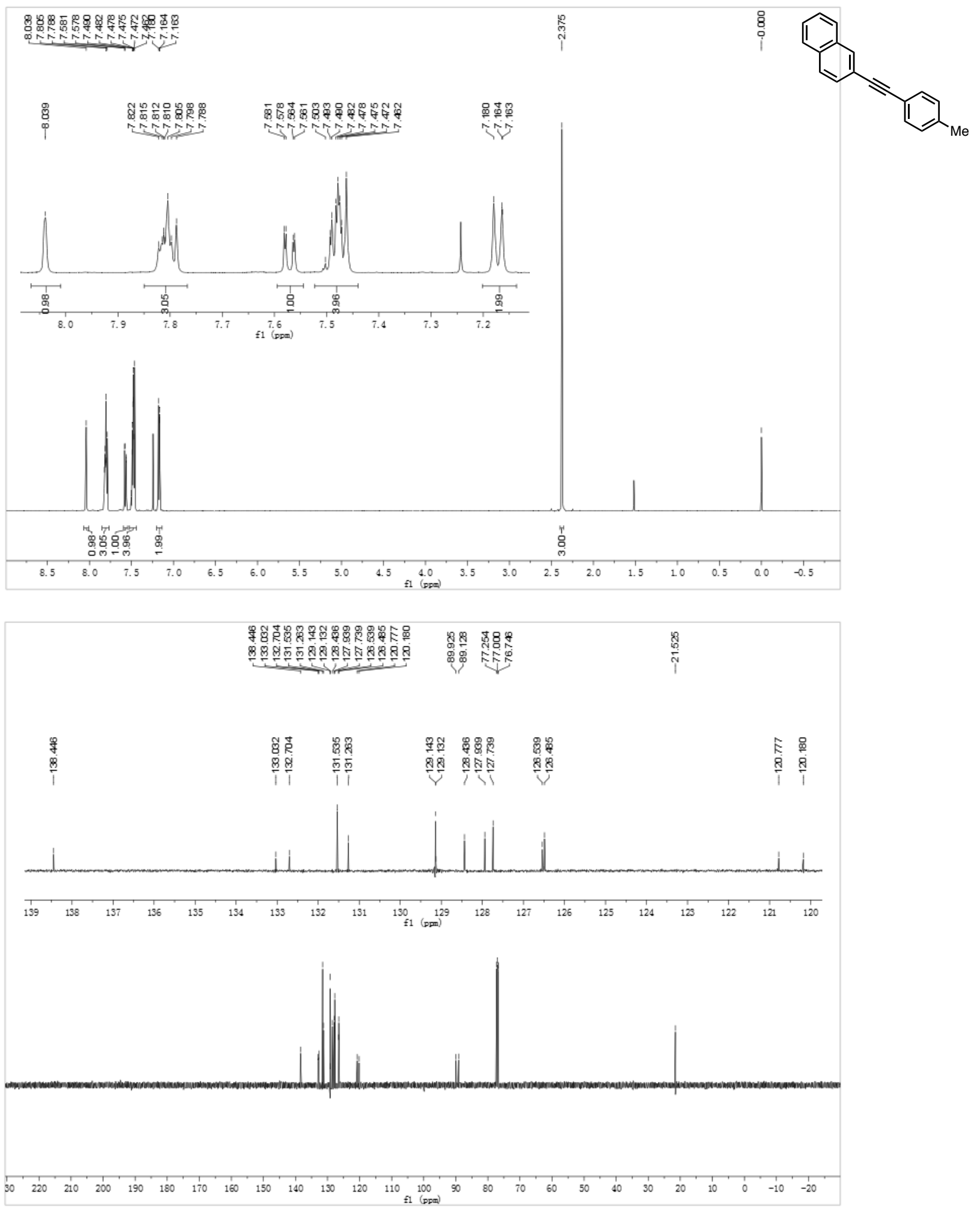


$1 d$

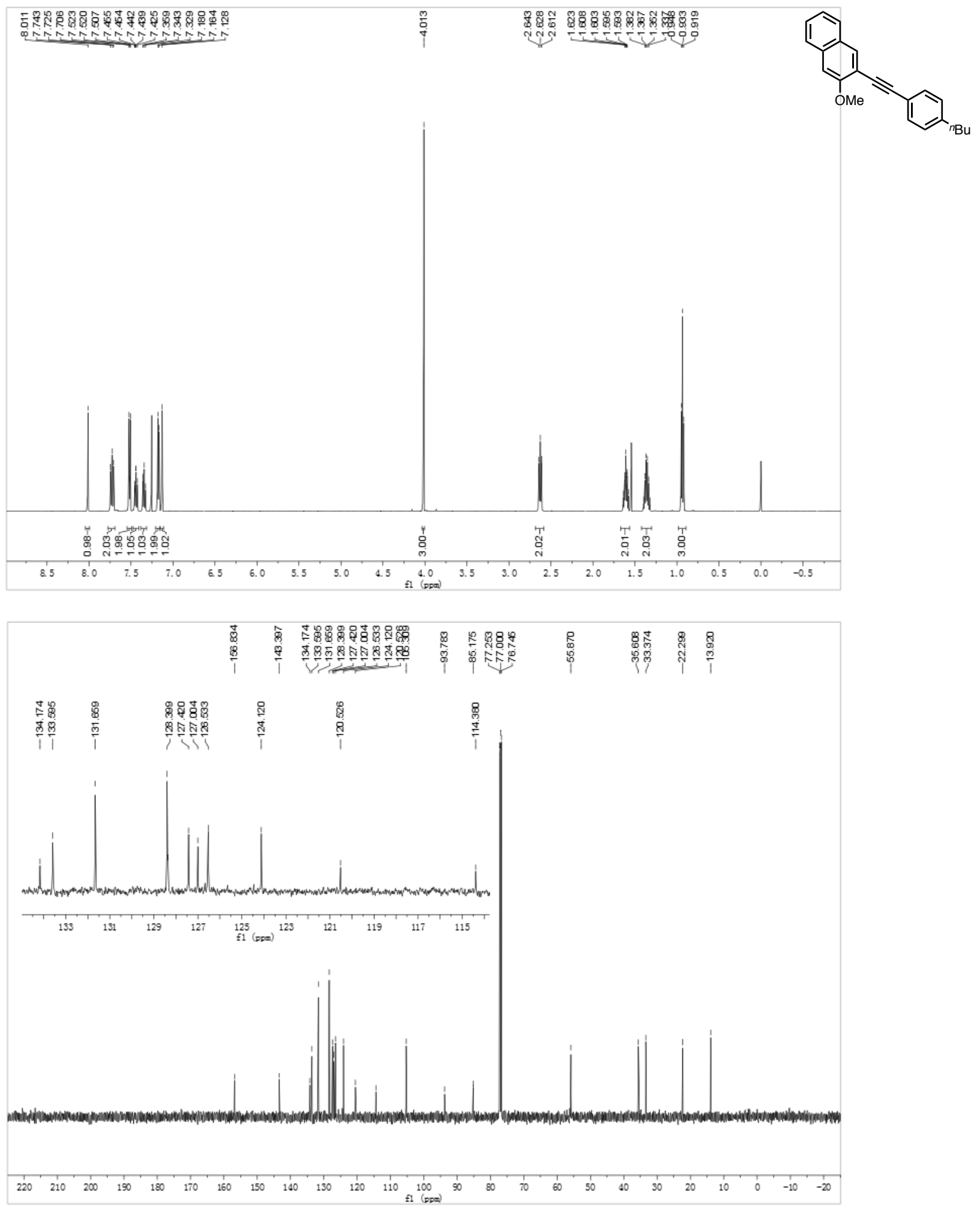


$1 e$

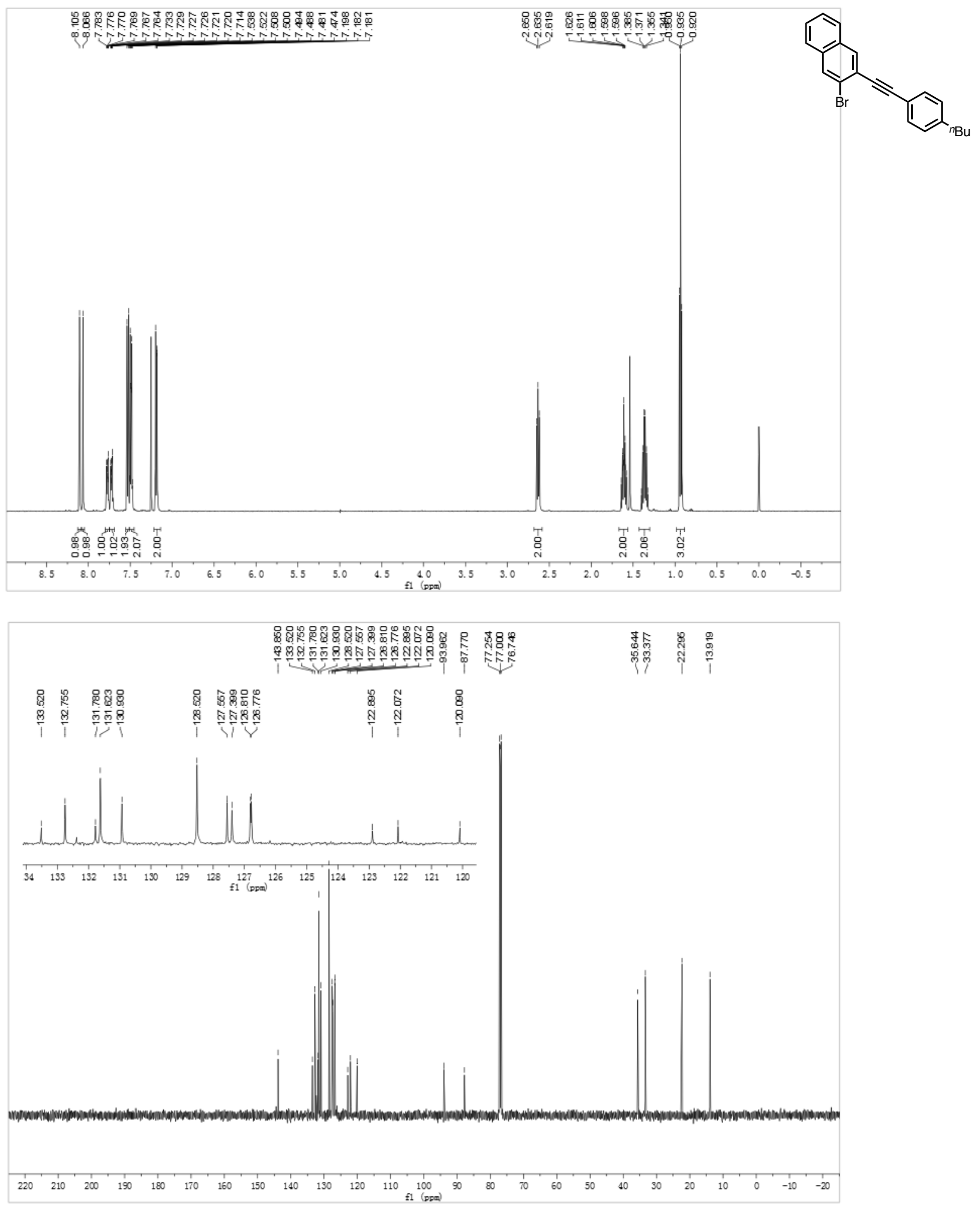


$1 f$

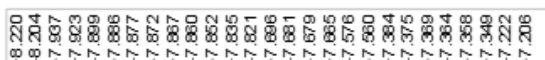

:

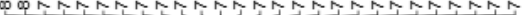

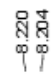

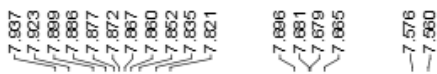

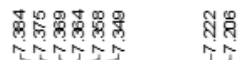

武被
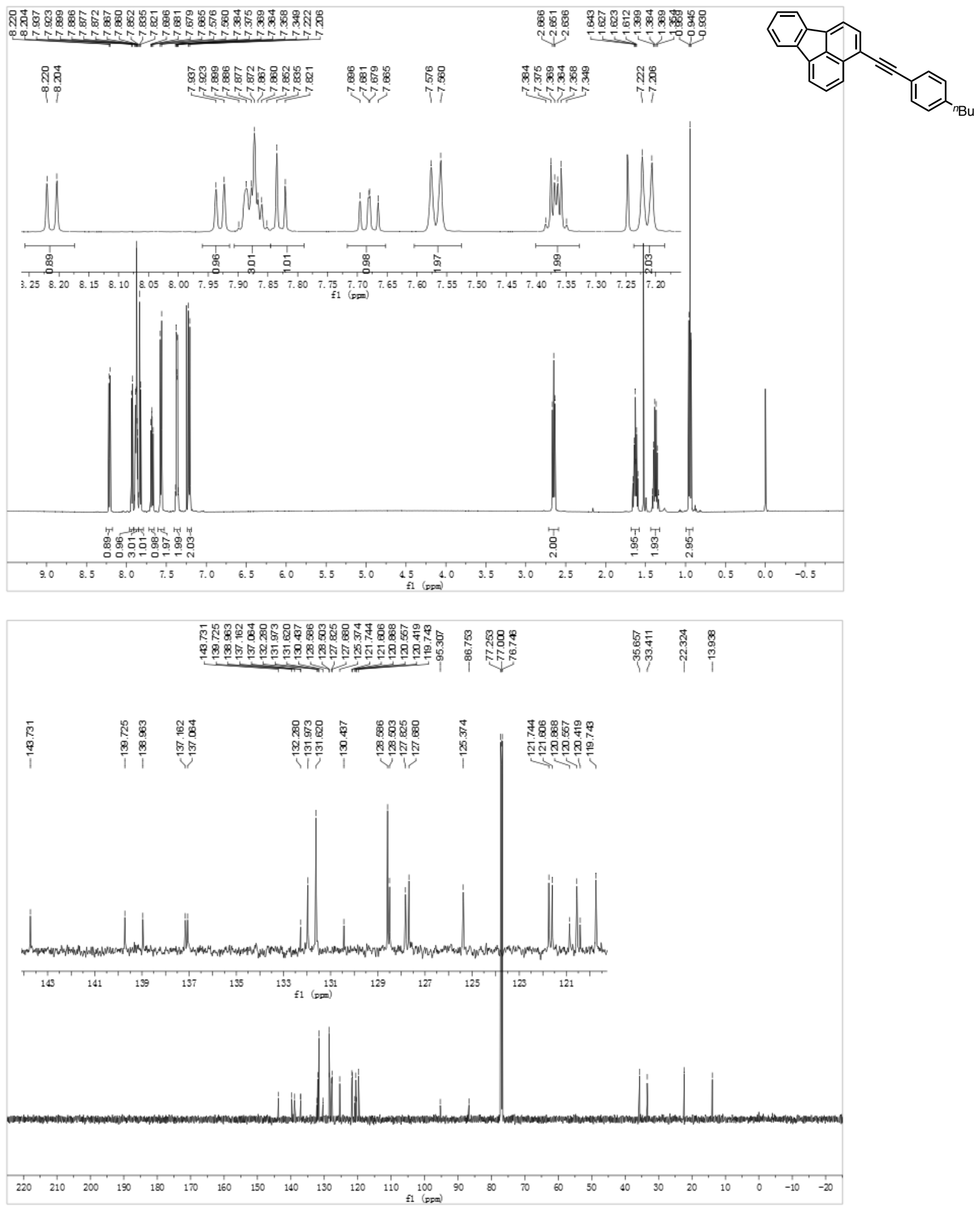
$1 \mathrm{~g}$

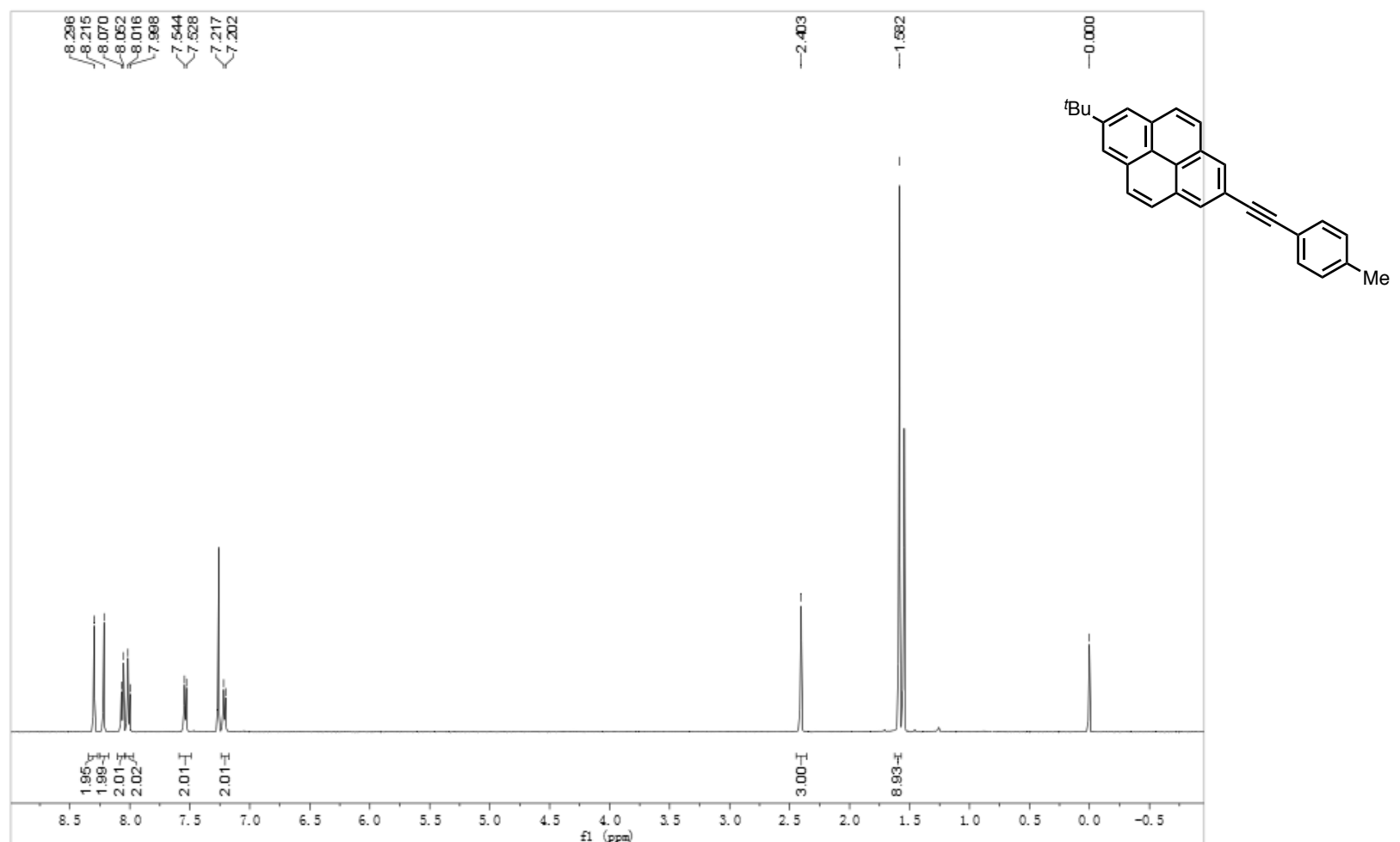

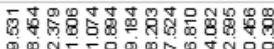

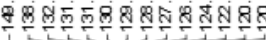

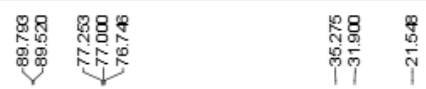

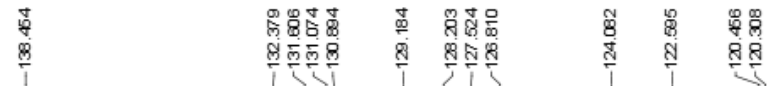

||||||||||||||

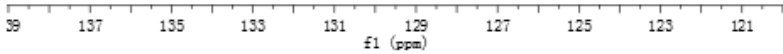

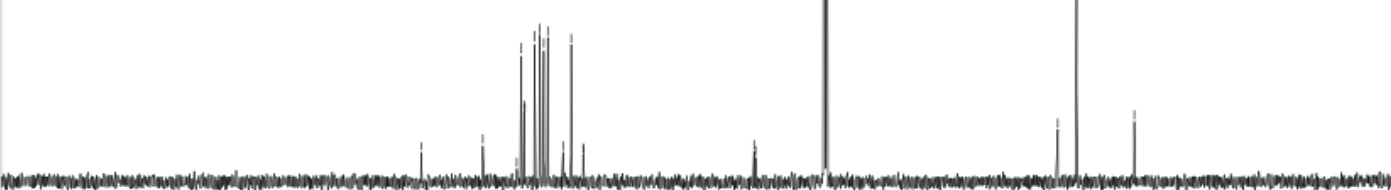

$\begin{array}{lllllllllllllllllllllllll}220 & 210 & 200 & 190 & 180 & 170 & 160 & 150 & 140 & 130 & 120 & 110 & 100 & 90 & 80 & 70 & 60 & 50 & 40 & 30 & 20 & 10 & 0 & -10 & -20\end{array}$ 
$1 h$

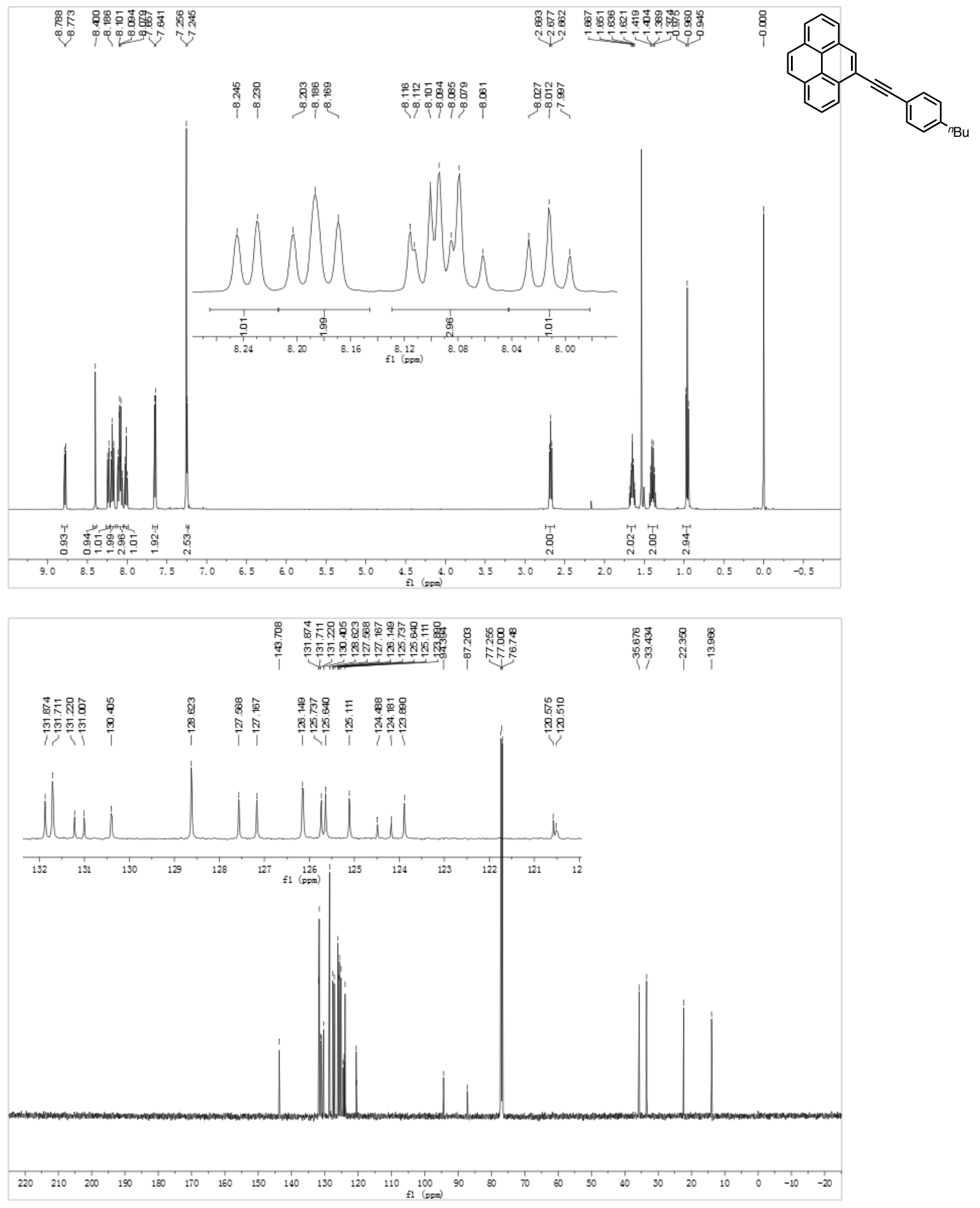


$1 \mathbf{1}$

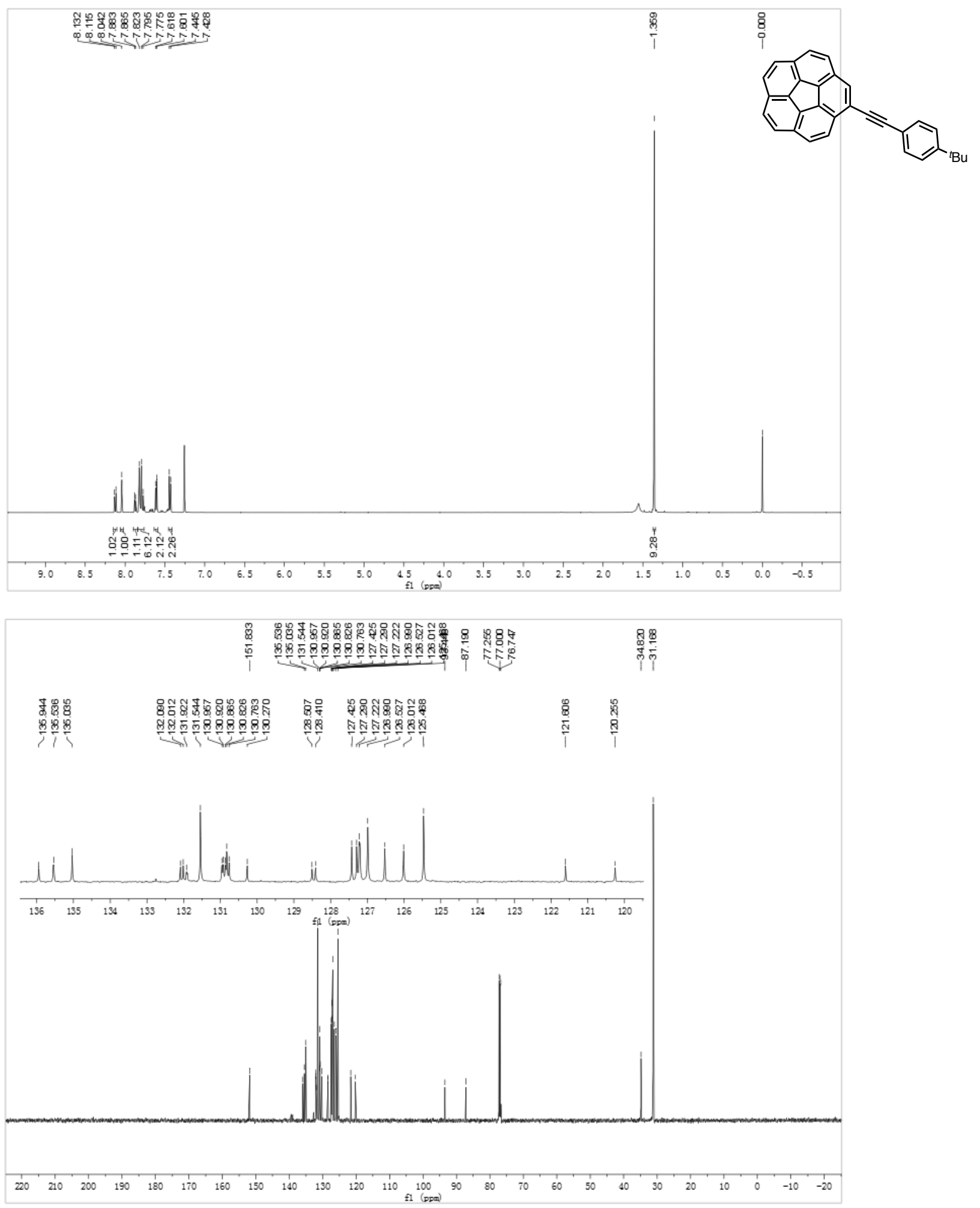


$1 \mathbf{j}$

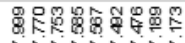

${ }^{n \mathrm{Bu}}-\langle\rangle=$

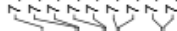

递哭

Iro

$\mid$

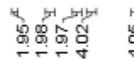

6.

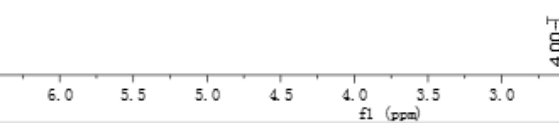

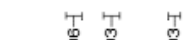
ले ले

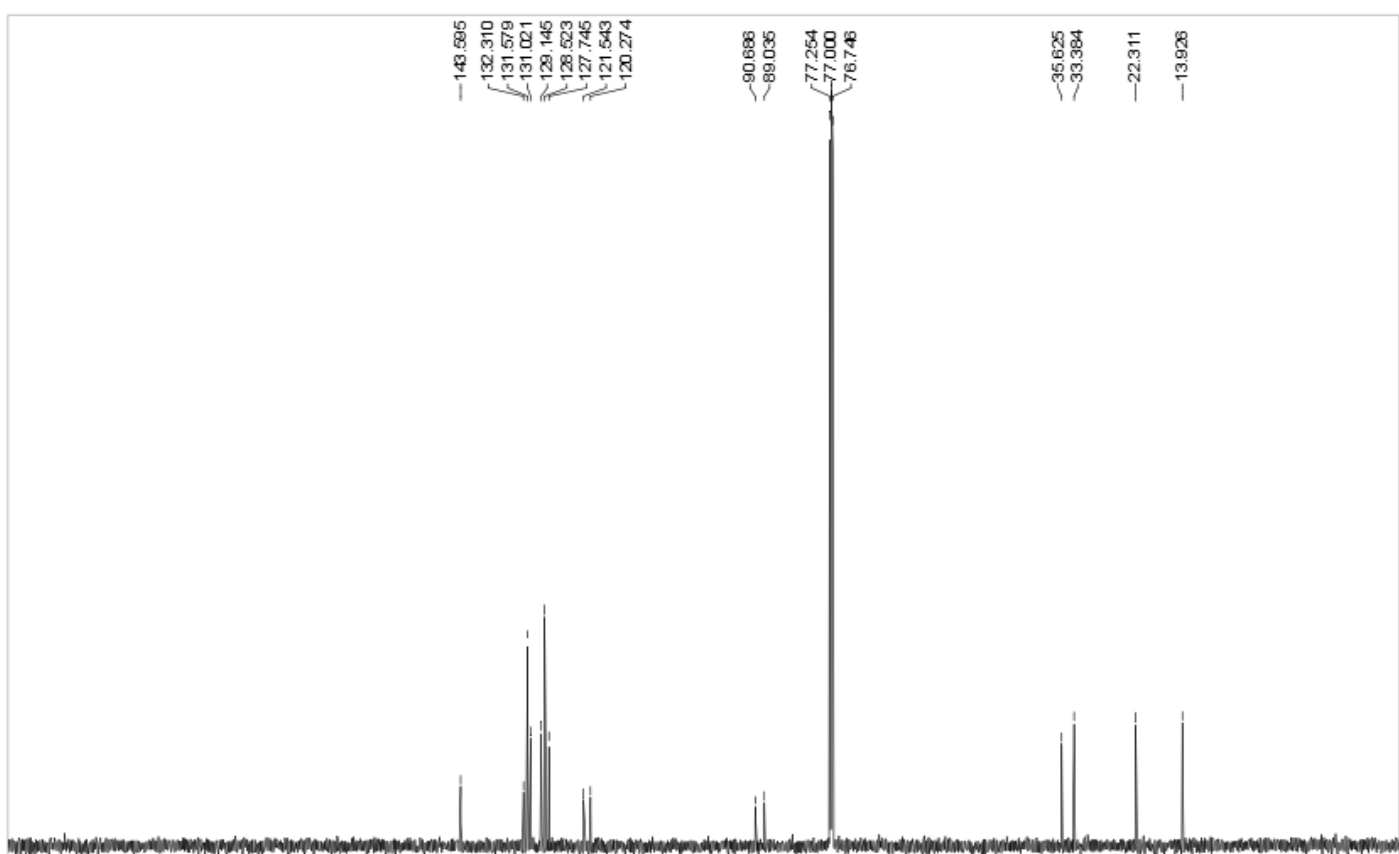

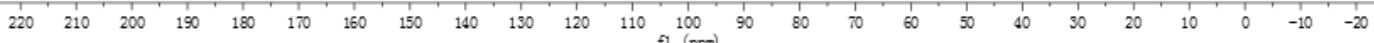


$1 k$

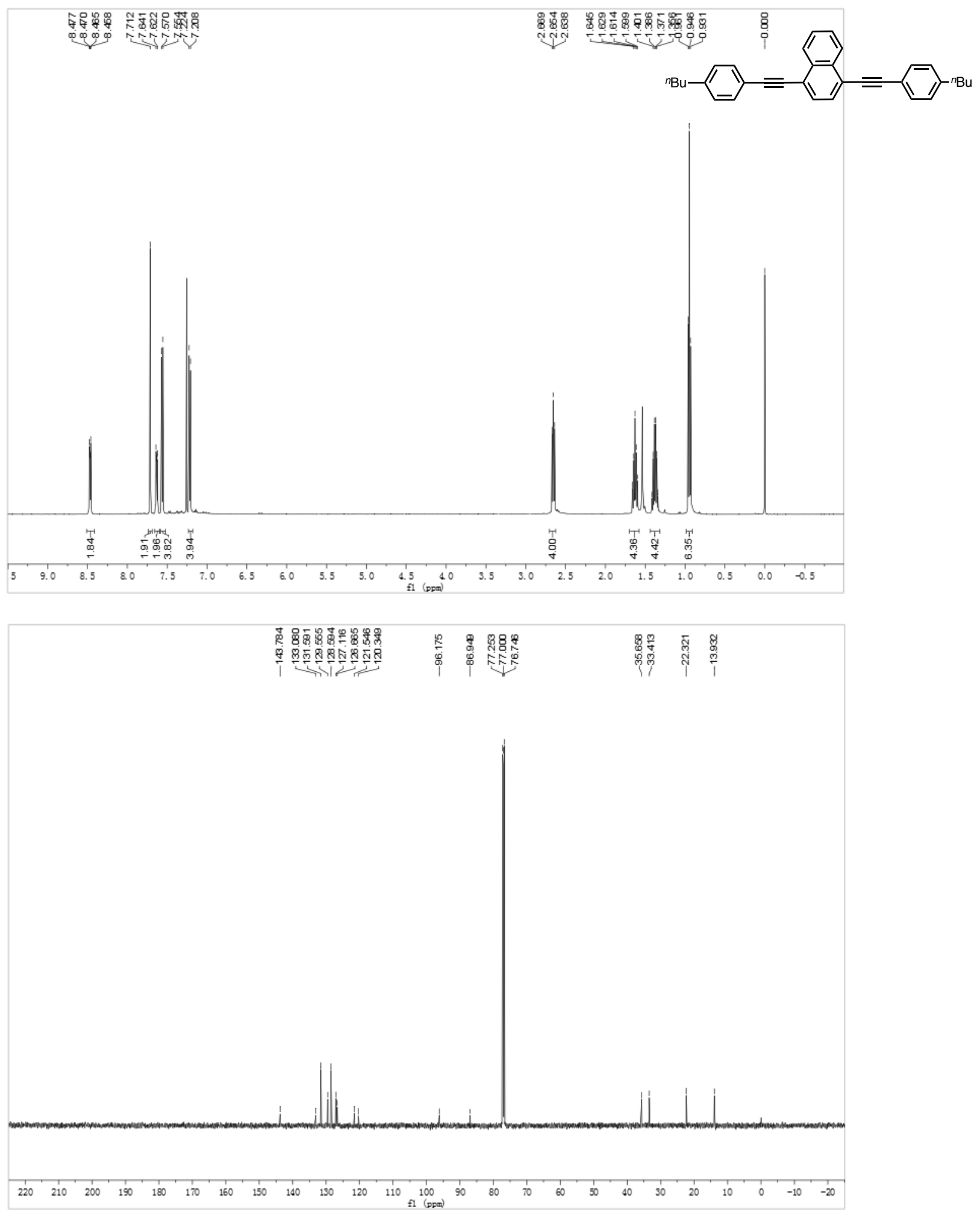



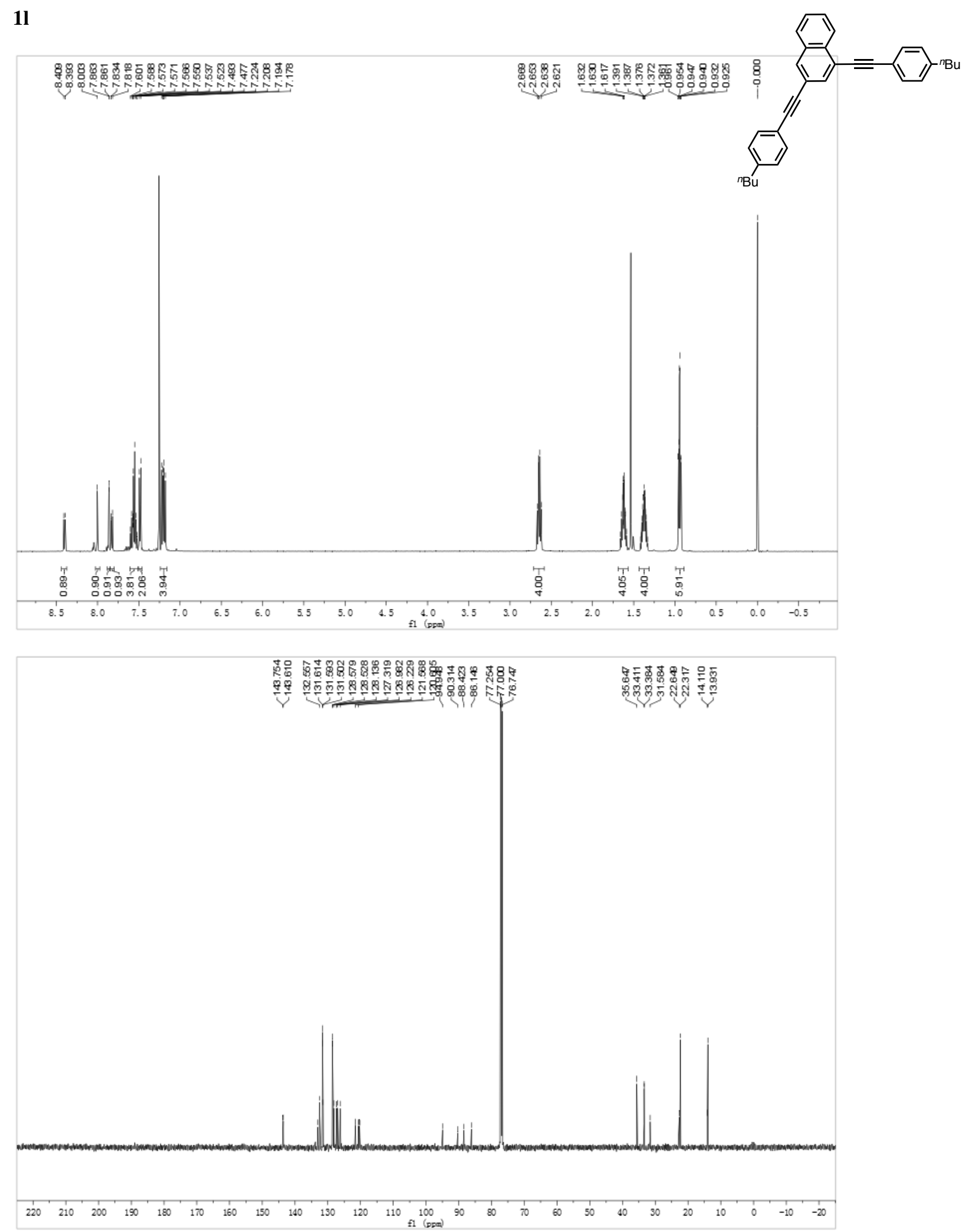
$1 \mathrm{~m}$

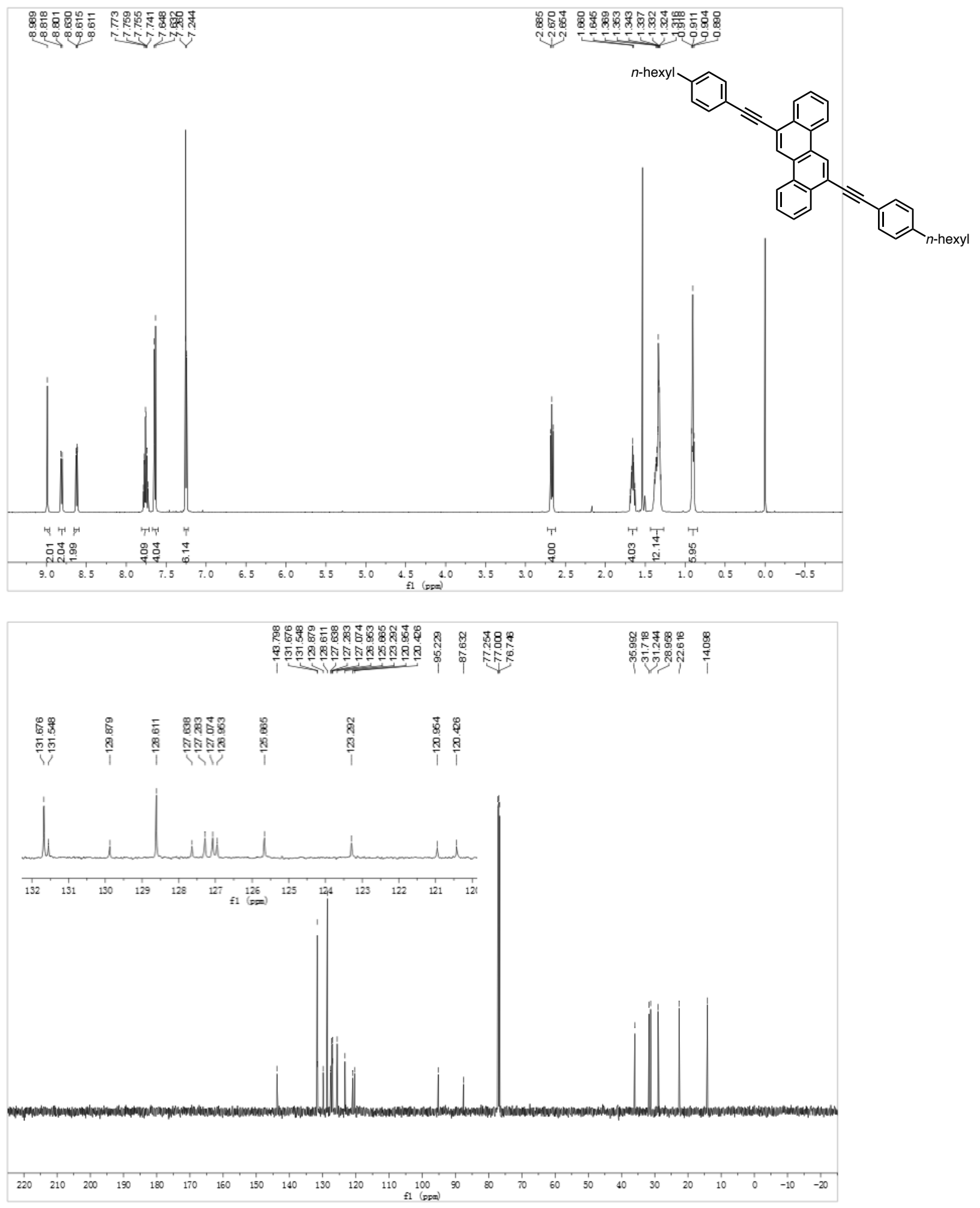


$1 n$
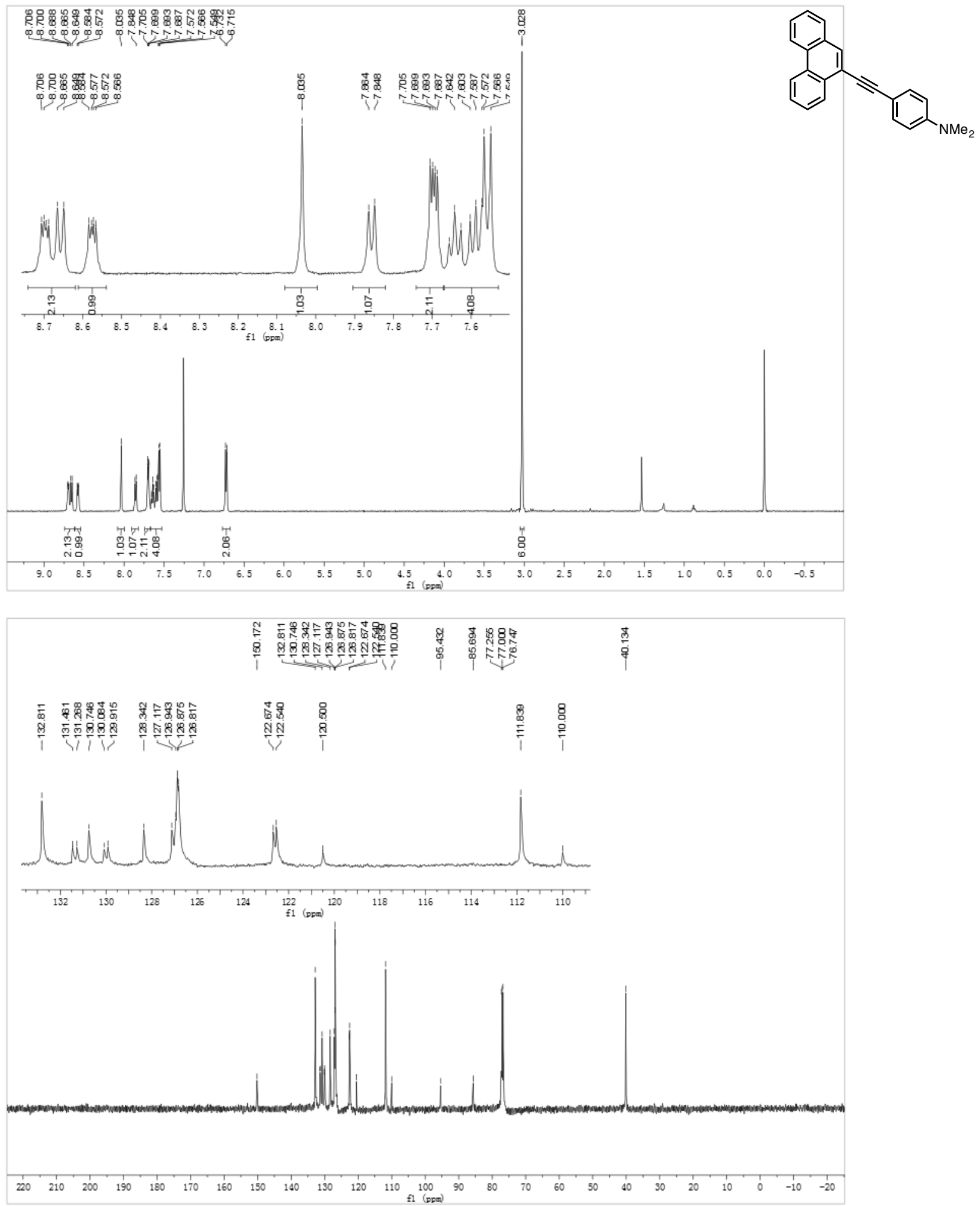
10

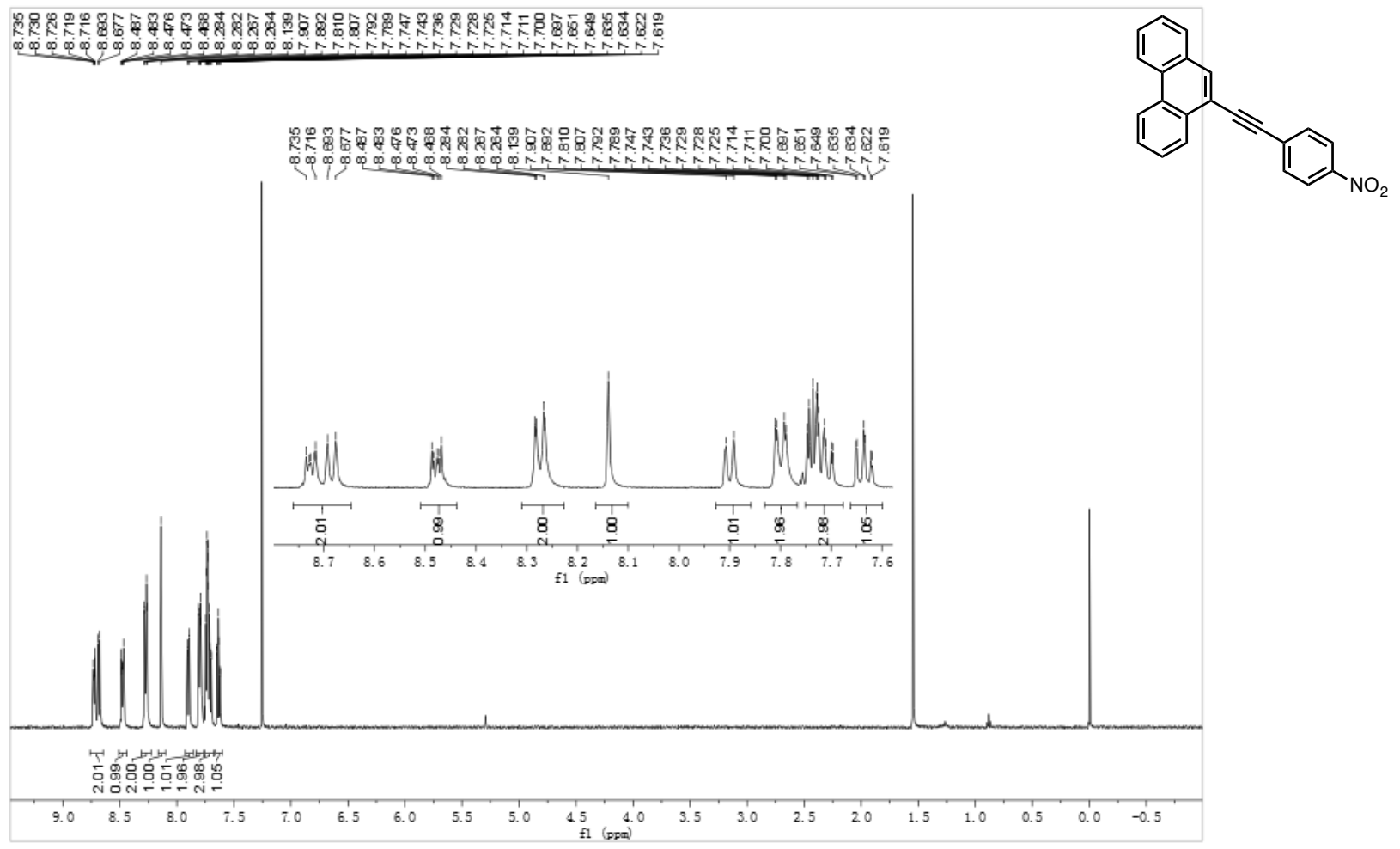

8 布

广

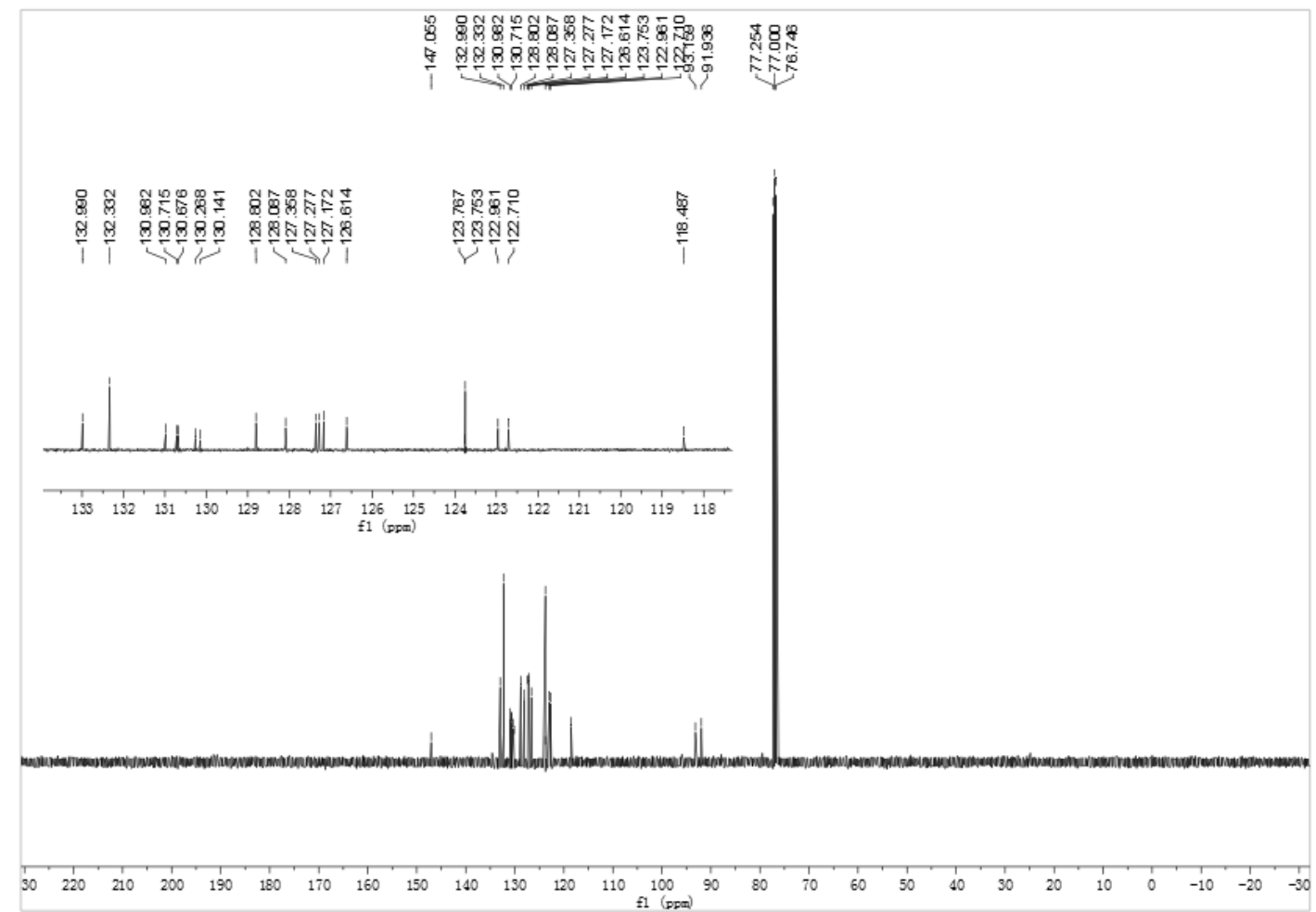




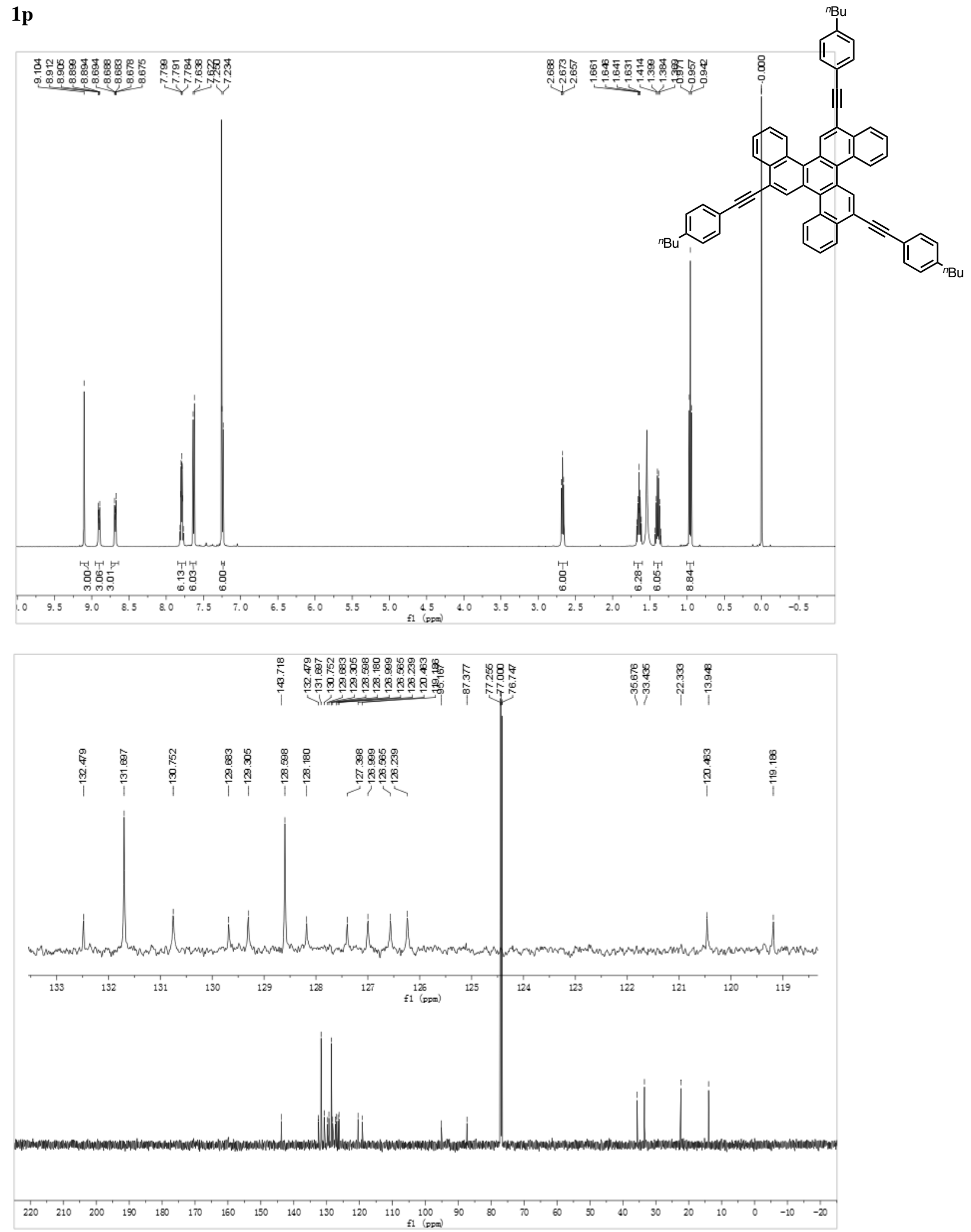


$1 q$
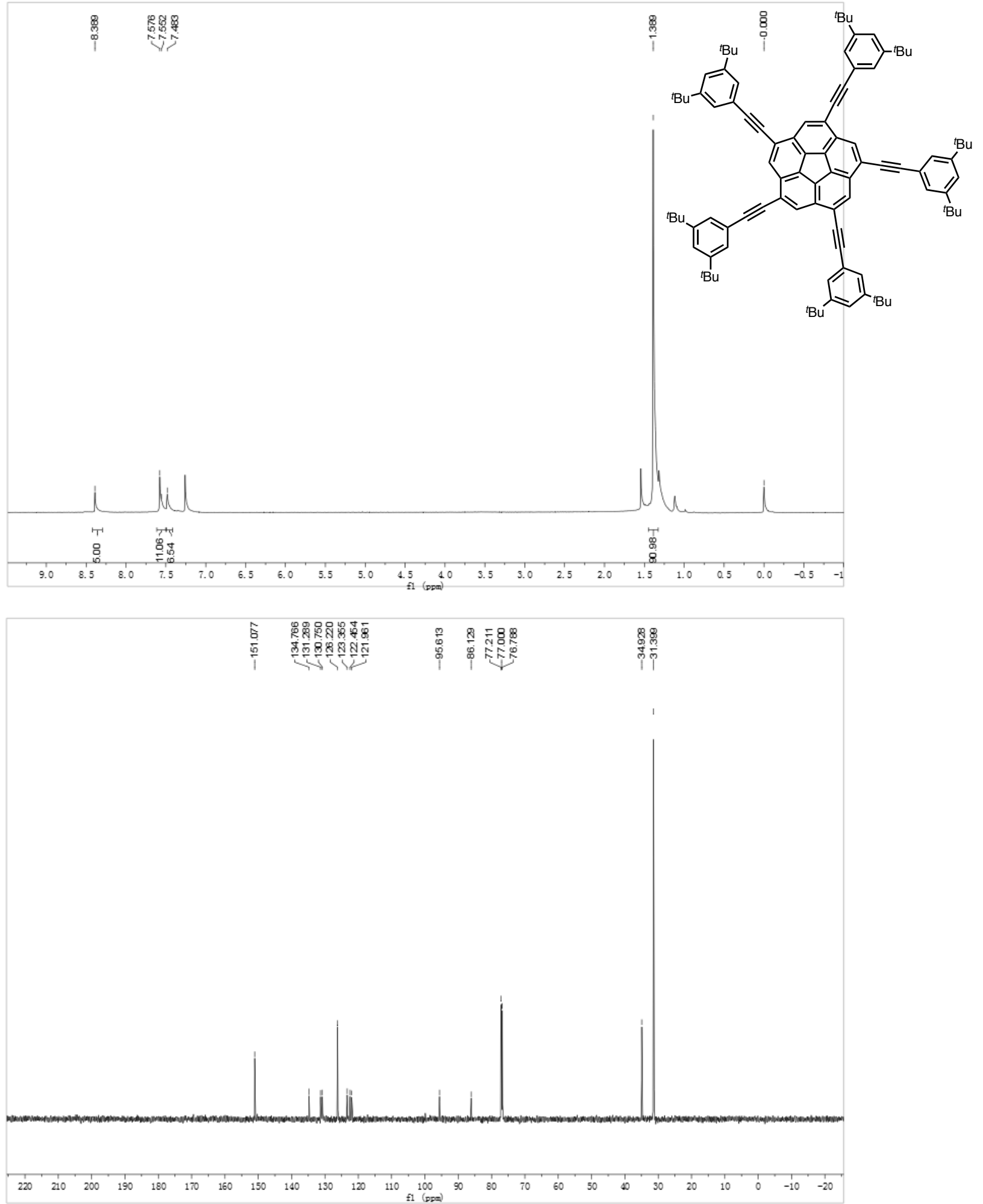
1r

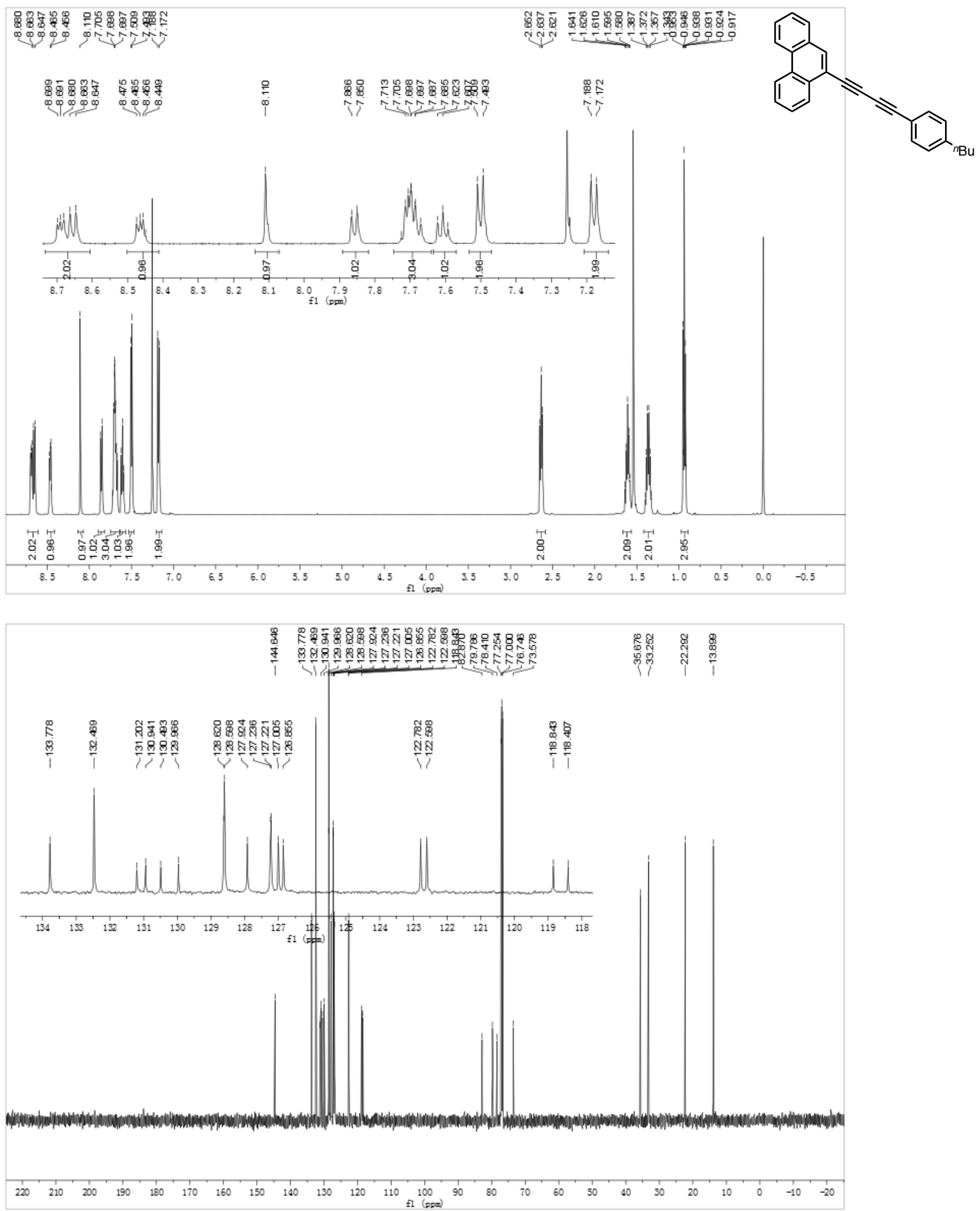


$1 s$

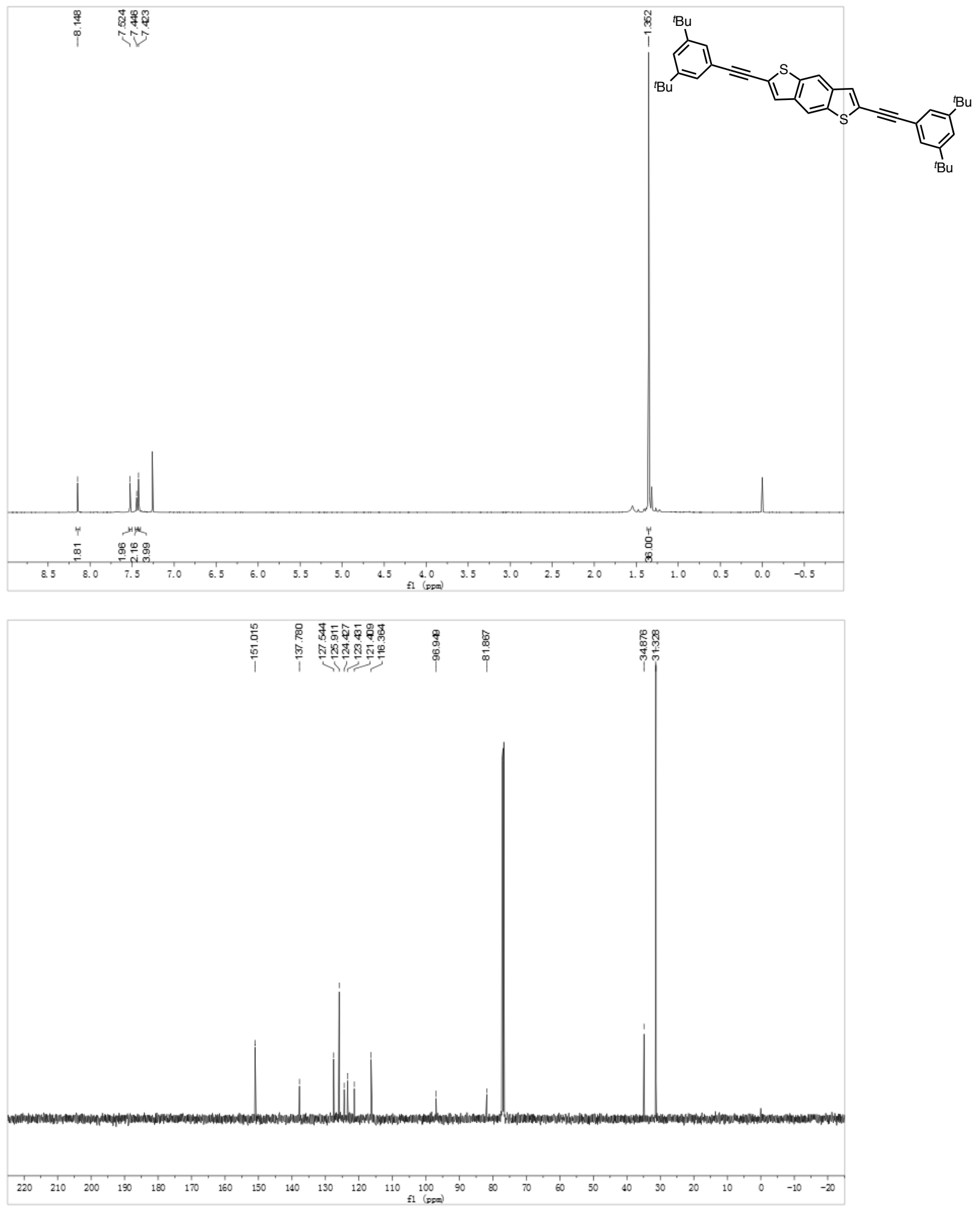



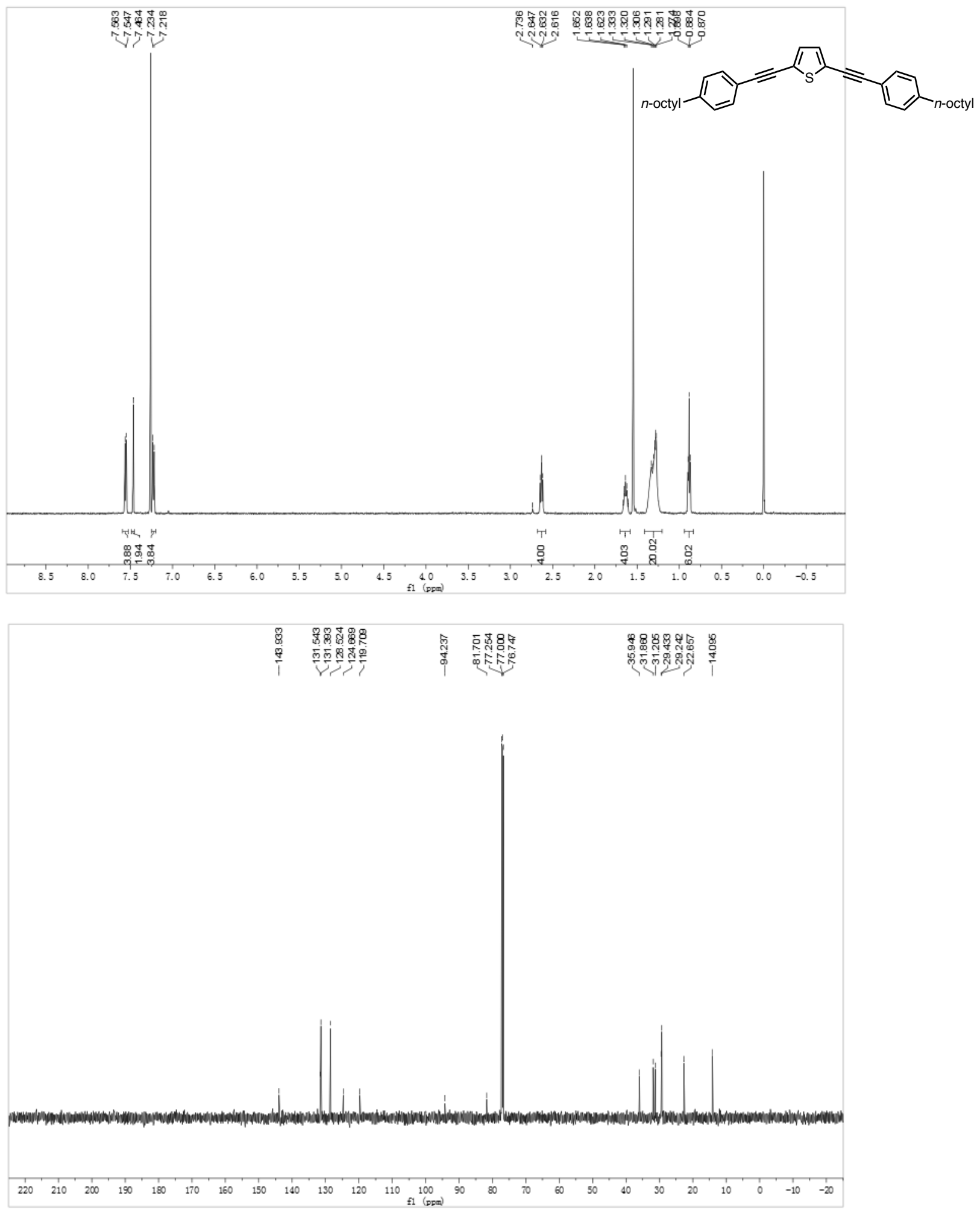